ORNL/TM-13482

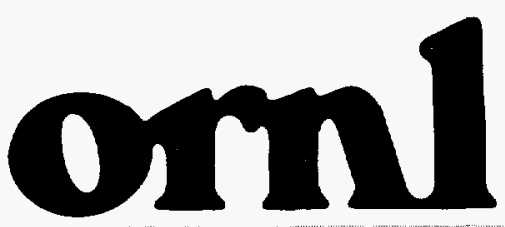

OAK RIDGE

NATIONAL

LABORATORY

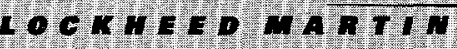
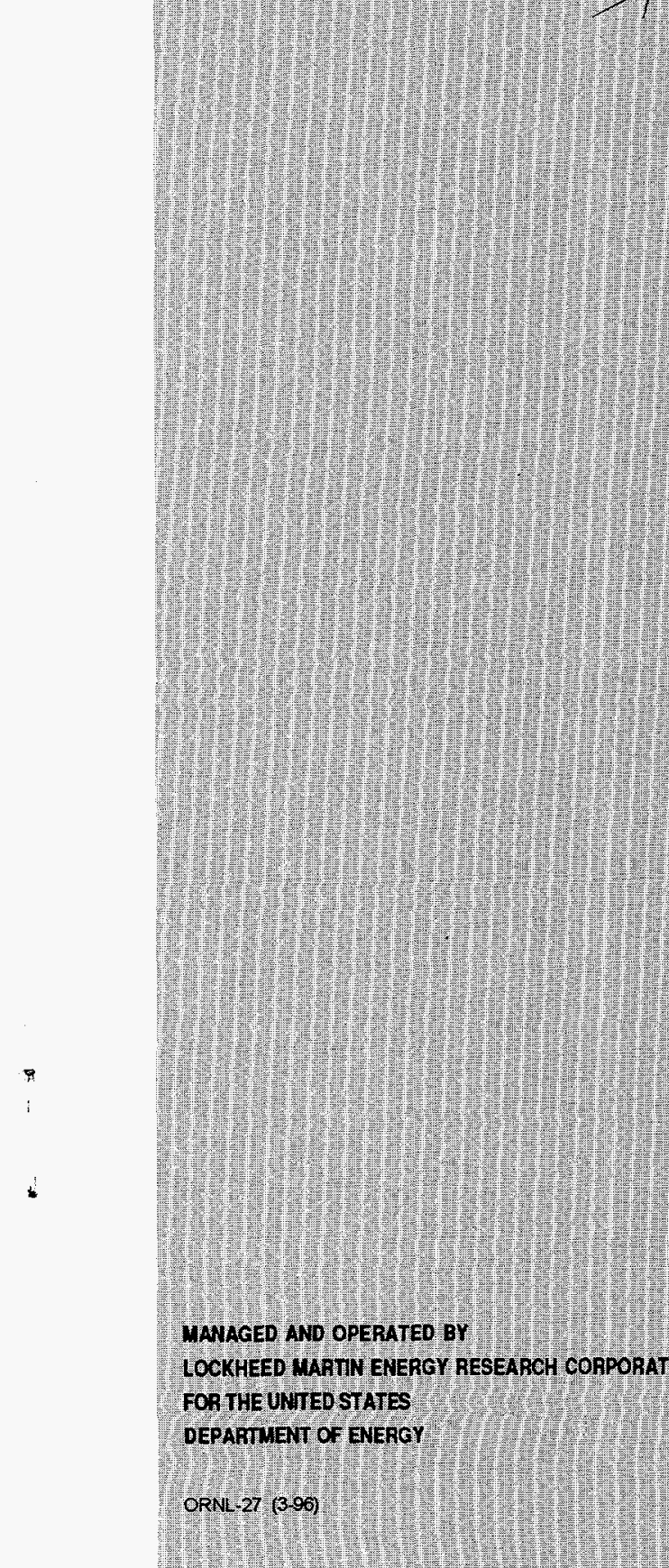

MANAGED AND OPERATED BY

LOCKHEED WARTIN ENERGY RESEARCH CORPORATION FOA THE UNTED STATES. DEPARTUENT OF ENERGY

\section{LANL MOX Fuel Lead Assemblies Data Report for the Surplus Plutonium Disposition Environmental Impact Statement}

Fissile Materials Disposition Program
REGEIVED SEP 291998 08.1 18. MASTEF

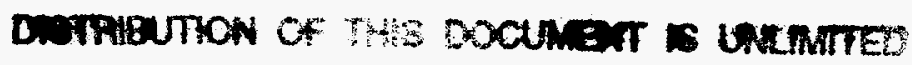


This report has been reproduced directly from the best available copy.

Available to DOE ancl DOE contractors from the Office of Scientific and Technical Information, P.O. Box 62, Oak Ridge, TN 37831; prices available from (423) 576-8401.

Available to the publiz from the National Technical Information Service, U.S. Department of Cornmerce, 5285 Port Royal Rd., Springfield, VA 22161.

This report was preparid as an account of work sponsored by an agency of the United States Goveinment. Neither the United States Government nor any agency thereof, nor any' of their employees, makes any warranty, express or implied, or assumes any legal liability or responsibility for the accuracy, completeness, or usefulness of any information, apparatus, product, or process disclosed, or represents that its use would not infringe privately owned rights. Reference herein to an! specific commercial product, process, or service by trade name, trademark, manufacturer, or otherwise, does not necessarily constitute or imply its endorsement, recommendation, or favoring by the United States Government or any agency thereof. The views and opinions of authors expressed herein do nol necessarily state or reflect those of the United States Govemment or any agericy thereof. 


\section{DISCLAIMER}

Portions of this document may be illegible in electronic image products. Images are produced from the best available original document. 


\title{
LANL MOX FUEL LEAD ASSEMBLIES DATA REPORT FOR THE SURPLUS PLUTONIUM DISPOSITION ENVIRONMENTAL IMPACT STATEMENT
}

\section{Project Manager}

S. R. Greene

Lead Assembly EIS Data Project Lead and Author D. G. O'Connor

\section{Contributing Authors}

QRNL

S. E. Fisher

R. Holdaway

$\underline{\text { LANL }}$

S. B. Ludwig

J. J. Buksa

R. C. Rangel

S. L. Eaton

S. A. Miller

R. N. Morris

H. R. Trellue

D. B. Garvey

R. A. Morley

R. C. Hurdle

R. R. Rahn

R. C. Stokes

A. M. Pendergrass

J. Sease

A. J. Montoya

M. A. Jones

V. S. White

J. D. Hoisington, Jr.

E. Mullen

K. L. McElhaney

R. C. Staroski

R. L. Carlson

J. J. Carbajo

D. J. Martinez

M. Lujan

J. J. Fitzgibbons

D. R. Brennan

M. A. Roybal

D. V. Christensen

R. L. Price, III

A. I-Li Chen

D. L. Brandt

B. B. Bates, Jr.

N. L. Teague

M. Barr

Date Published: August 1998

\author{
Prepared by \\ OAK RIDGE NATIONAL LABORATORY \\ Oak Ridge, Tennessee 37831 \\ managed by \\ LOCKHEED MARTIN ENERGY RESEARCH CORP. \\ for the \\ U.S. DEPARTMENT OF ENERGY \\ under contract DE-AC05-96OR22464
}


Page Intentionally Blank 


\section{CONTENTS}

Page

LIST OF FIGURES

LIST OF TABLES

ACRONYMS

ABSTRACT.

1. INTRODUCTION AND SCHEDULE.

2. SITE MAP AND THE LA FACILITY DESCRIPTION.

2.1 TA-55 AND PF-4

2.2 TA-3 AND CMR BUILDING

2.3 TA-18

2.4 TA-50

$2.5 \quad$ TA-54

2.6 PAJARITO ROAD

3. PROCESS DESCRIPTIONS

3.1 PROCESS FLOW DIAGRAM........................................................................................................................... 19

3.2 WASTE MANAGEMENT FLOW DIAGRAMS.................................................................................. 19

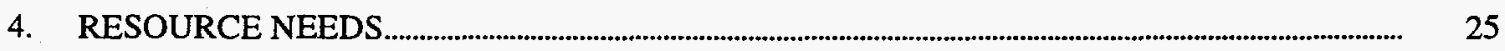

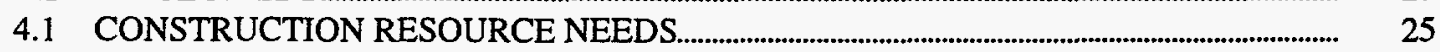

4.2 OPERATIONAL RESOURCE NEEDS ................................................................................................... 25

4.2.1 Utilities .......................................................................................................................... 26

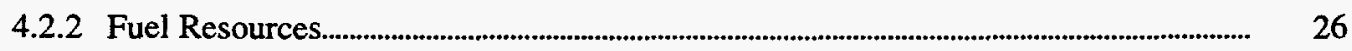

4.2.3 Water ................................................................................................................................. 28

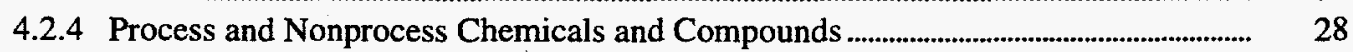

4.2.5 Radioactive Process Materials............................................................................................. 30

5. EMPLOYMENT REQUIREMENTS................................................................................................................ 31

5.1 ANNUAL EMPLOYMENT REQUIREMENTS DURING OPERATION

OF THE LA FABRICATION FACILITY

5.2 RADIATION DOSES (WHOLE BODY) TO INVOLVED WORKERS

DURING MODIFICATION OF THE LA FABRICATION FACILITY .................................... $\quad 31$

5.3 RADIATION DOSES (WHOLE BODY) TO INVOL VED WORKERS

DURING OPERATION OF THE LA FABRICATION FACILITY .............................................. $\quad 32$

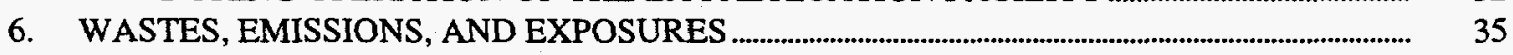

6.1 WASTE GENERATED DURING FACILITY MODIFICATION

6.2 WASTES GENERATED DURING OPERATION OF THE FACILITY................................... $\quad 35$

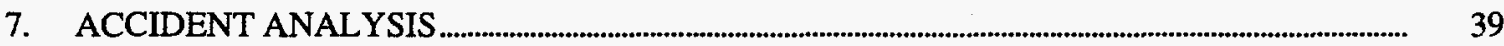

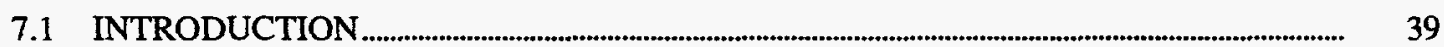

7.2 GENERAL APPROACH AND GENERIC DESIGN ASSUMPTIONS...................................... 39

7.2.1 Accident Analysis Approach............................................................................................... 39

7.2.2 Facility Design Assumptions .............................................................................................. $\quad 40$

7.3 SELECTED EVENTS FOR THE LA EIS ANALYSIS …................................................................ 43

7.3.1 Criticality Event............................................................................................................................ 43

7.3.2 Evaluation Basis Seismic Event.............................................................................................. 45

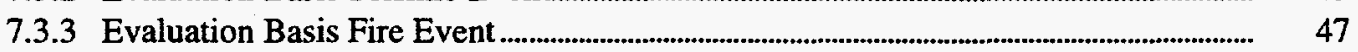

7.3.4 Evaluation Basis Explosion Event...................................................................................... 49

7.3.5 Beyond-Evaluation Basis Seismic Event .............................................................................. 51

7.3.6 Beyond-Evaluation Basis Major Building Fire............................................................................ 51

7.4 EVALUATION OF POTENTIAL CHEMICAL SOURCE TERMS......................................... 53

7.5 SITE SPECIFICS FOR THE LANL PF-4 BUILDING ……..............................................

7.5.1 Stack Release Height ..................................................................................................................... 53

7.5.2 Evaluated Seismic Attributes ......................................................................................................... 53 


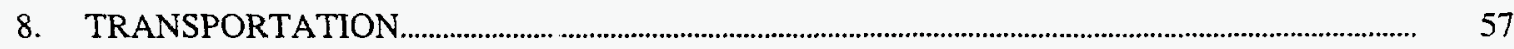

8.1 OPERATIONS-RELATED TRANSPORTATION REQUIREMENTS ……........................... 57

8.1.1 Feed Materials .................................................................................................................... $\quad 57$

8.1.2 Fresh MOX Fuel As semblies.................................................................................................... 57

8.1.3 Spent MOX Fuel Assemblies......................................................................................... 57

9. QUALITATIVE DECONTAMINATION AND DECOMMISSIONING DISCUSSION............... 63

9.1 INTRODUCTION ......................................................................................................................... 63

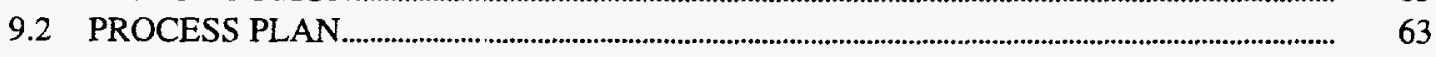

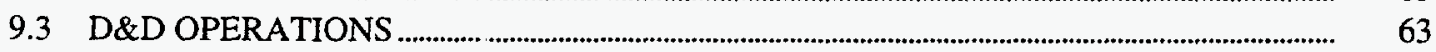

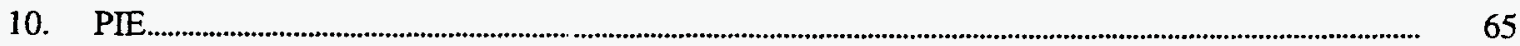

10.1 PIE DISCUSSION..................................................................................................................

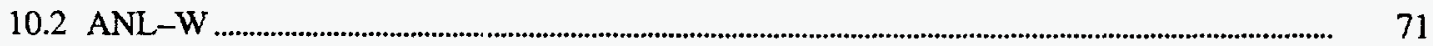

10.2.1 Main Cell .................................................................................................................

10.2.2 Decon Cell............................................................................................................................. $\quad 72$

10.2.3 Metallographic Loading Box ....................................................................................................... 73

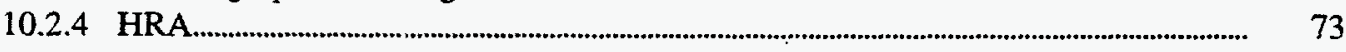

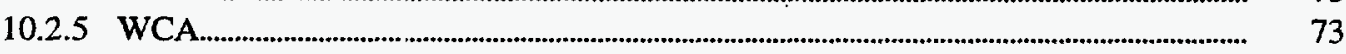

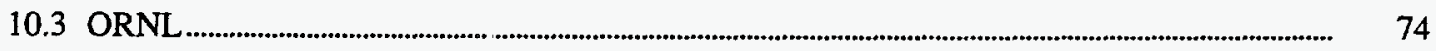

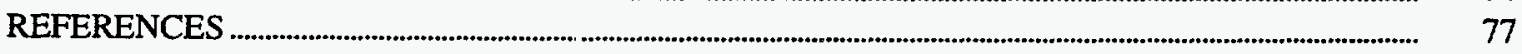

Appendix A-LA FUEL BUNDLE FAERICATION ......................................................................................... A-1

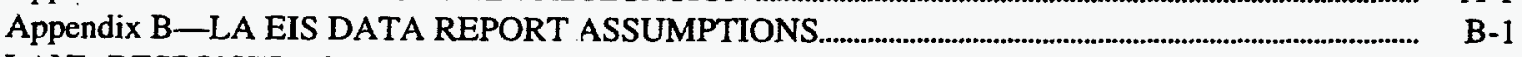

LANL RESPONSE TO THE SUPPLEMENTAL LEAD TEST ASSEMBLY EIS DATA CALL.......... S-1 


\section{LIST OF FIGURES}

Figure $\quad$ Page

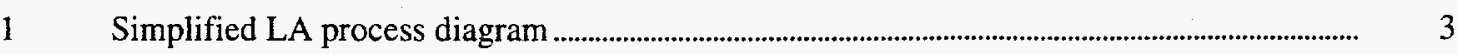

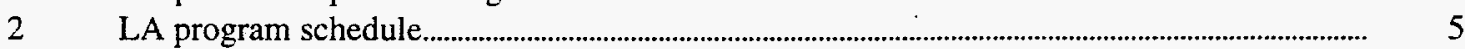

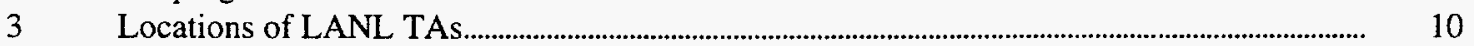

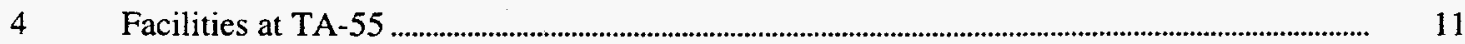

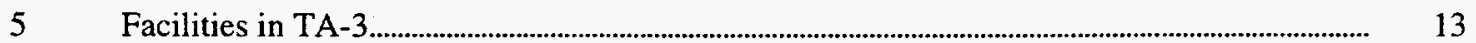

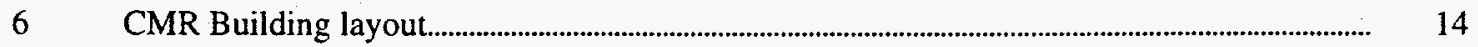

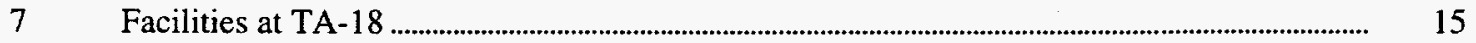

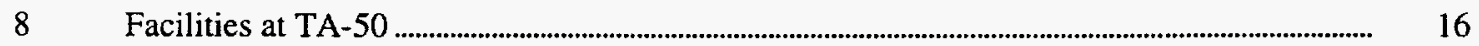

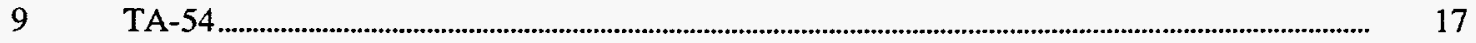

10 LA MOX fuel flow sheet outline with annual throughputs.............................................................. 20

11 Waste generated during LA MOX fuel fabrication facility operation ............................................. 22

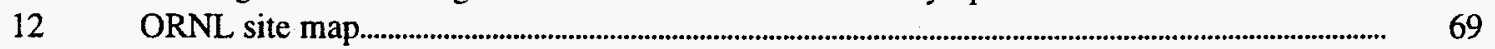

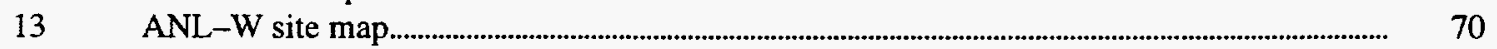

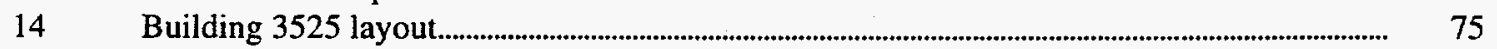

A.1 LA MOX fuel pellet flow sheet outline ......................................................................................... A-3

A.2 LA MOX fuel $\mathrm{PuO}_{2}$ powder receipt and storage........................................................................................ A-4

A.3 Detailed flow sheet of LA pellet fabrication ...................................................................................... A-5

A.4 Detailed flow sheet of LA rod fabrication ........................................................................................... A-6

A.5 Detailed flow sheet of LA bundle assembly (LWR) ................................................................................. A-7 
F'age Intentionally Blank 


\section{LIST OF TABLES}

LA fabrication facility schedule

LA testing schedule

LA MOX fuel material requirements.

Assumptions made to determine LA MOX fuel material requirements ..........................................

Potential functions for each facility.

LA MOX fuel fabrication requirements

Manpower required for glove box line modifications.

Resource needs during operation of the LA fabrication facility

Annual employment requirements during operation of the LA fabrication facility ................ 32

Assumptions used in consideration of staffing levels for the LA fabrication facility.............. $\quad 32$

Radiation doses (whole body) to involved workers during modification of the

LA fabrication facility

Radiation doses (whole body) to involved workers during operation of the

LA fabrication facility

Estimated waste generated during operation of the LA fabrication facility

Specific activities for process powders

Estimated maximum station inventories for LA fabrication plant.

Source term for the evaluation basis criticality event

Source term for the evaluation basis seismic event

Source term for the evaluation basis fire

Source term for the evaluation basis explosion.

Source term for beyond the evaluation basis seismic event

Source term for beyond the evaluation basis major building fire/building collapse

Comparison of LA facility annual usage and reportable quantity per 40 CFR 302 ..

Transportation of $\mathrm{PuO}_{2}$ to support LA fabrication.

Transportation of depleted $\mathrm{UO}_{2}$ to support LA fabrication.

Transportation of materials to support LA fabrication (LEU fuel assemblies)

Transportation of LAs to generic reactor site.

Fresh MOX fuel isotopic content.

Transportation of irradiated LAs to PIE site.

Spent MOX fuel isotopic content.

Examples of casks for LWR spent fuel.

Estimated waste generated during the LA PIE

Radiation doses to involved workers during LA PIE.

PIE estimates for EIS

Assumptions used for the LA EIS data reports 


\section{Page Intentionally Blank}




\section{ACRONYMS}

ACL

AEC

AL

ALARA

ARF

ANL-W

ASTM

BRET

BWR

CAA

CCCTF

CEDE

CERCLA

CFA

CFR

$\mathrm{CH}$

CMC

CMR

CRBR

CS

CST

CWA

$D \& D$

D\&R

dc

DOE

DWPF

EA

EBR-I

EBR-II

EIS

EJ

EPA

ER

ETB

FAA

FCF

FCFS

FEMA

FFTF

FMEF

FMF

FONSI

FR

FSAR

FTE

HAP

HEPA

HEU

HFEF/S

administrative control level

U.S. Atomic Energy Commission

analytical laboratory

as low as reasonably achievable

airborne release fraction

Argonne National Laboratory-West (at INEEL)

American Society for Testing and Materials

Breeder Reprocessing Engineering Test

boiling-water reactor

Clean Air Act

Core Conduction Cooldown Test Facility

committed effective dose equivalent

Comprehensive Environmental Response, Compensation,and Liability Act of 1980

Central Facilities Area (ANL-W)

Code of Federal Regulations

contact-handled

confirmatory measurement counter

Chemistry and Metallurgy Research

Clinch River Breeder Reactor

containment and surveillance

Chemical Science and Technology

Clean Water Act of 1972

decontamination and decommissioning

dismantling and rearrangement

direct current

U.S. Department of Energy

defense waste processing facility

environmental assessment

Experimental Breeder Reactor-I

Experimental Breeder Reactor-II

environmental impact statement

environmental justice

Environmental Protection Agency

Environmental Report

Engineering Test Bay

Fuel Assembly Area

Fuel Cycle Facility

Fueled Clad Fabrication System

Federal Emergency Management Agency

Fast-Flux Test Facility

Fuels and Materials Examination Facility

Fuel Manufacturing Facility

finding of no significant impact

fire resistive

final safety analysis report

full-time equivalent

hazardous air pollutant

high-efficiency particulate air

highly enriched uranium

Hot Fuel Examination Facility South 


\begin{tabular}{|c|c|}
\hline$H M$ & heavy metal \\
\hline HP & Health Physics \\
\hline HPFL & High-Performance Fuel Laboratory \\
\hline HVAC & heating, ventilating, and air conditioning \\
\hline HWMA & Hazardous Waste Management Act of 1983 \\
\hline $\mathrm{I} \& \mathrm{C}$ & Instrumentation and Controls \\
\hline IDAPA & Idaho Administ ative Procedures Act \\
\hline IFEL & Irradiated Fuels Examination Laboratory \\
\hline IFR & Integral Fast Rexctor \\
\hline IMGA & Irradiated Micrcsphere Gamma Analyzer \\
\hline INEEL & Idaho National Engineering and Environmental Laboratory \\
\hline INRAD & Intrinsic Radiation Bay \\
\hline LA & lead assembly \\
\hline LACEF & Los Alamos Critical Experiments Facility \\
\hline LANL & Los Alamos National Laboratory \\
\hline LLMW & low-level mixed waste \\
\hline LLRW & low-level radioartive waste \\
\hline LLW & low-level waste \\
\hline LLNL & Lawrence Livermore National Laboratory \\
\hline LMES & Lockheed Martir. Energy Systems, Inc. \\
\hline LMITCO & Lockheed Martin Idaho Technologies Company \\
\hline LTA & lead-test assembly \\
\hline LUA & lead-use assembly \\
\hline LWR & light-water reactcor \\
\hline MAA & Material Access Area \\
\hline $\mathrm{M} \& \mathrm{C}$ & Metals and Ceranics \\
\hline MC\&A & material control and accountability \\
\hline MD & Office of Fissile Materials Disposition (DOE) \\
\hline MFP & multiple fission products \\
\hline MOX & mixed oxide \\
\hline MT & metric ton \\
\hline MW & mixed waste \\
\hline NDA & nondestructive as:ay \\
\hline NDT & nondestructive testing \\
\hline NEPA & National Environrnental Policy Act of 1969 \\
\hline NGVD & National Geodetic Vertical Datum \\
\hline NMS\&S & Nuclear Material Stabilization and Storage Division \\
\hline NMSS & Office of Nuclear Material Safety and Safeguards \\
\hline NPDES & National Pollutant Discharge Elimination System \\
\hline NRC & Nuclear Regulatory Commission \\
\hline ORNL & Oak Ridge Nationil Laboratory \\
\hline ORR & Oak Ridge Reservation \\
\hline PA & protected area \\
\hline PDAC & pit disassembly and conversion \\
\hline PDI & pressure differential indicator \\
\hline PDIC & pressure differential indicating controller \\
\hline PDT & pressure differential transmitter \\
\hline PF & Plutonium Facility \\
\hline PFP & Plutonium Finishing Plant \\
\hline PIDAS & Perimeter Intrusion and Detection Assessment System \\
\hline PIE & postirradiation examination \\
\hline PPE & personal protective equipment \\
\hline PSF & Plutonium Storage Facility \\
\hline PWR & pressurized-water reactor \\
\hline
\end{tabular}




$\begin{array}{ll}\text { QA } & \text { quality assurance } \\ \text { R\&D } & \text { research and development } \\ \text { RAMROD } & \text { Radioactive Materials Research, Operations, and Demonstration Facility } \\ \text { RCRA } & \text { Resource Conservation and Recovery Act of 1976 } \\ \text { RCT } & \text { Radiological Control Technician } \\ \text { RF } & \text { respirable fraction } \\ \text { RH } & \text { remote handled } \\ \text { RLWTF } & \text { Radioactive Liquid Waste Treatment Facility } \\ \text { RMAL } & \text { Radioactive Materials Analytical Laboratory } \\ \text { ROD } & \text { record of decision } \\ \text { RPSF } & \text { Radioisotope Power Systems Facility } \\ \text { RSSF } & \text { Radioactive Sodium Storage Facility } \\ \text { RSWF } & \text { Radioactive Scrap and Waste Facility } \\ \text { S\&D } & \text { storage and disposition } \\ \text { S\&S } & \text { safeguards and security } \\ \text { SAF } & \text { secure automated facility } \\ \text { SAR } & \text { safety analysis report } \\ \text { SCDHEC } & \text { South Carolina Department of Health and Environmental Control } \\ \text { SEM } & \text { scanning electron microscope } \\ \text { SIP } & \text { Space Isotope Program } \\ \text { SNF } & \text { spent nuclear fuel } \\ \text { SNFM } & \text { spent nuclear fuel material } \\ \text { SNM } & \text { special nuclear material } \\ \text { SPSP } & \text { Space Power Systems Project } \\ \text { SRS } & \text { Savannah River Site } \\ \text { SRTC } & \text { Savannah River Technology Center } \\ \text { SST } & \text { safe secure transport } \\ \text { TA } & \text { Technical Area } \\ \text { TAP } & \text { toxic air pollutant } \\ \text { TEDE } & \text { total effective dose equivalent } \\ \text { TREAT } & \text { Transient Reactor Test Facility } \\ \text { TRU } & \text { transuranic } \\ \text { TSCA } & \text { Toxic Substances Control Act } \\ \text { TSDF } & \text { treatment, storage, and/or disposal facility } \\ \text { UBC } & \text { Uniform Building Code } \\ \text { USF } & \text { Uranium Solidification Facility } \\ \text { W. } & \text { Westinghouse } \\ \text { WAG } & \text { Waste Area Group } \\ \text { WCL } & \text { Waste Characterization Laboratory } \\ \text { WCRRF } & \text { Waste Characterization, Reduction, and Repackaging Facility } \\ \text { WG } & \text { weapons grade } \\ \text { WIPP } & \text { Waste Isolation Pilot Plant } \\ \text { WOC } & \text { White Oak Creek } \\ \text { WRAP } & \text { Waste Receiving and Processing Plant } \\ \text { WSRC } & \text { Westinghouse Savannah River Company } \\ \text { ZPPR } & \end{array}$





\title{
LANL MOX FUEL LEAD ASSEMBLIES DATA REPORT FOR THE SURPLUS PLUTONIUM DISPOSITION ENVIRONMENTAL IMPACT STATEMENT
}

\author{
Project Manager \\ S. R. Greene \\ Lead Assembly EIS Data Project Lead and Author \\ D. G. O'Connor
}

\begin{abstract}
The purpose of this document is to support the U.S. Department of Energy (DOE) Fissile Materials Disposition Program's preparation of the draft surplus plutonium disposition environmental impact statement. This is one of several responses to data call requests for background information on activities associated with the operation of the lead assembly (LA) mixed-oxide (MOX) fuel fabrication facility.

The DOE Office of Fissile Materials Disposition (DOE-MD) has developed a "dual-path" strategy for disposition of surplus weapons-grade plutonium. One of the paths is to disposition surplus plutonium through irradiation of MOX fuel in commercial nuclear reactors. MOX fuel consists of plutonium and uranium oxides $\left(\mathrm{PuO}_{2}\right.$ and $\left.\mathrm{UO}_{2}\right)$, typically containing $95 \%$ or more $\mathrm{UO}_{2}$.

DOE-MD requested that the DOE Site Operations Offices nominate DOE sites that meet established minimum requirements that could produce MOX LAs. Six initial site combinations were proposed: (1) Argonne National Laboratory-West (ANL-W) with support from Idaho National Engineering and Environmental Laboratory (INEEL), (2) Hanford, (3) Los Alamos National Laboratory (LANL) with support from Pantex, (4) Lawrence Livermore National Laboratory (LLNL), (5) Oak Ridge Reservation (ORR), and (6) Savannah River Site (SRS). After further analysis by the sites and DOE-MD, five site combinations were established as possible candidates for producing MOX LAs: (1) ANL-W with support from INEEL, (2) Hanford, (3) LANL, (4) LLNL, and (5) SRS. Pantex was removed as a supporting organization to LANL because Pantex did not have facilities available that met the desired programmatic criteria. One of the criteria was that existing buildings would be used for the mission. Pantex had no available existing buildings that it was willing to propose for this limited mission. ORR was removed by DOE-MD from consideration because it lacked adequate Safeguards and Security (S\&S) Category I facilities, which would limit the quantity of material that could be processed at a given time.

LANL has proposed an LA MOX fuel fabrication approach that would be done entirely inside an S\&S Category I area. This includes receipt and storage of $\mathrm{PuO}_{2}$ powder, fabrication of $\mathrm{MOX}$ fuel pellets, assembly of fuel rods and bundles, and shipping of the packaged fuel to a commercial reactor site. Support activities will take place within both Category $I$ and II areas.

Technical Area (TA) 55/Plutonium Facility 4 will be used to store the bulk $\mathrm{PuO}_{2}$ powder, fabricate MOX fuel pellets, assemble rods, and store fuel bundles. Bundles will be assembled at a separate facility, several of which have been identified as suitable for that activity. The Chemistry and Metallurgy Research Building (at TA-3) will be used for analytical chemistry support. Waste operations will be conducted in TA-50 and TA-54. Only very minor modifications will be needed to accommodate the LA program. These modifications consist mostly of minor equipment upgrades.

A commercial reactor operator has not been identified for the LA irradiation. Postirradiation examination (PIE) of the irradiated fuel will take place at either Oak Ridge National Laboratory or ANL-W. The only modifications required at either PIE site would be to accommodate full-length irradiated fuel rods.

Results from this program are critical to the overall plutonium distribution schedule.
\end{abstract}


Fage Intentionally Blank 


\section{INTRODUCTION AND SCHEDULE}

As part of the overall mission to disposition weapons-grade (WG) plutonium as fuel for commercial nuclear power plants, a lead assembly (LA) program is needed to qualify mixed-oxide (MOX) fuel as a safe and reliable fuel. The LA program will provide key data regarding the performance of MOX fuel in U.S. commercial reactors and supply information needed to modify current U.S. Nuclear Regulatory Commission (NRC) licenses. The program will also provide information necessary to validate and verify computer codes used in the reactor core design and accident analyses. In addition to qualifying the MOX fuel and validating and verifying the codes, the LA program will serve to verify that the United States can indeed execute each technical step necessary in the process of dispositioning plutonium as MOX fuel, except NRC licensing of facilities.

A simplified diagram showing each of the required process steps for the LA program is shown in Fig. 1. The LA program will include every step needed to complete the reactor portion of the plutonium disposition mission (including transportation and storage), with the exception of placement of the spent fuel in the geologic repository. In all likelihood, some of the LA program MOX fuel bundles will make their way to the geologic repository, but subsequent disposal in the repository is analyzed in other environmental documents. Detailed descriptions of the process required to fabricate MOX fuel, irradiate the fuel, and perform postirradiation examinations (PIE) of the spent fuel will be provided in Chaps. 3 and 10.

As previously stated, the goals of the LA program are to qualify the MOX fuel, confirm codes, and demonstrate that the United States can perform the steps necessary to disposition plutonium using MOX fuel. For the LA program these steps start with receipt of acceptable plutonium oxide $\left(\mathrm{PuO}_{2}\right)$ that is derived from "pits" and processed in the United States. At each step in the process, safeguards and security (S\&S) measures, material control and accountability (MC\&A) measures, transportation issues, storage issues, and material handling issues will be addressed. As shown in Fig. 1, the $\mathrm{PuO}_{2}$ is mixed and blended with

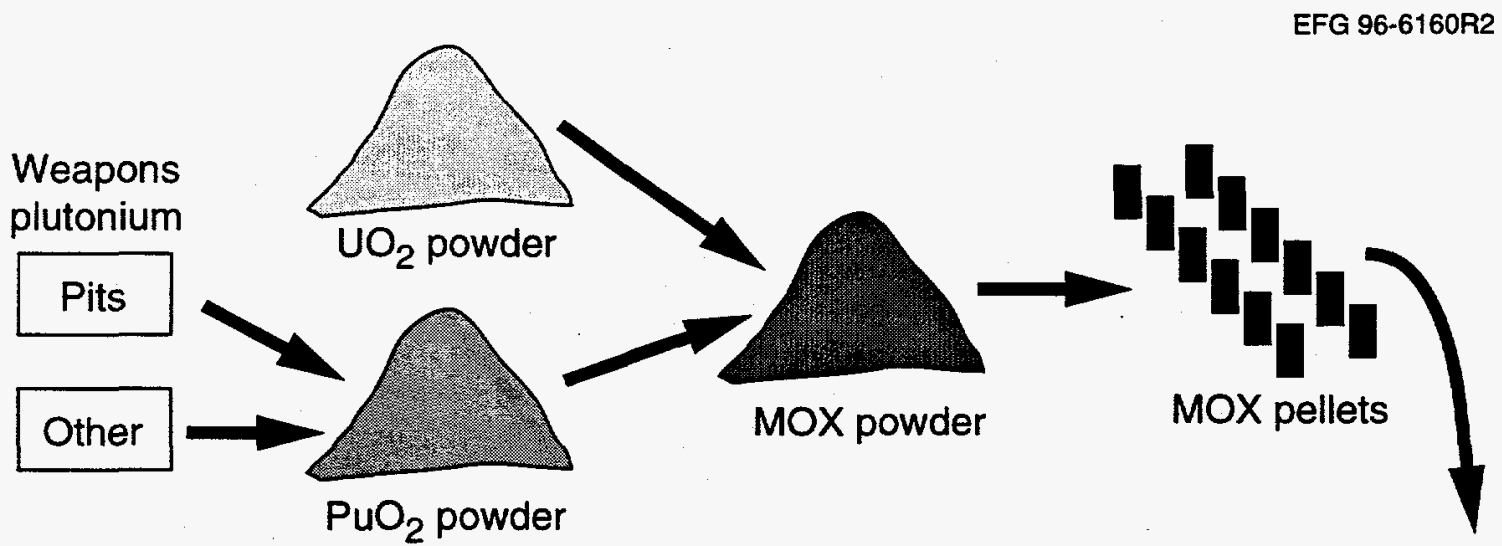

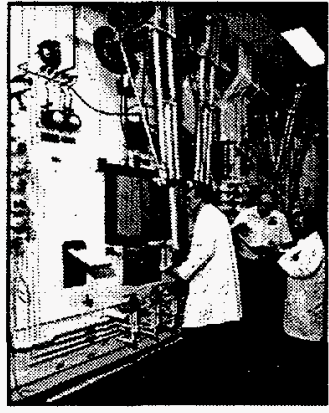

PIE

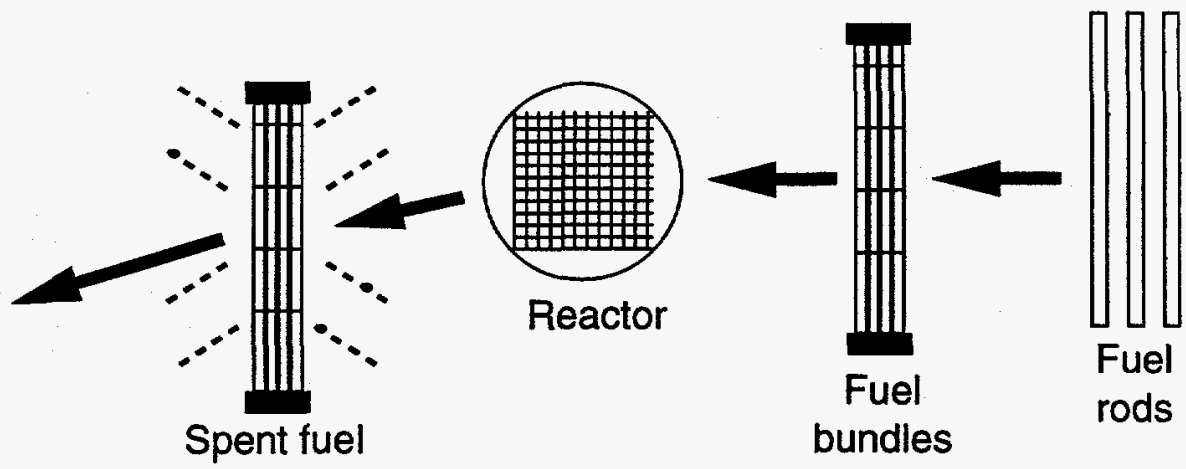

Fig. 1. Simplified LA process diagram. 
uranium oxide $\left(\mathrm{UO}_{2}\right)$ to arrive at the fissile content requested by the utility fuels engineer. Pellets are then pressed, sintered, and assembled into rods. The rods are then assembled into fuel assemblies and packaged for shipping to the reactor site for irraliation. After irradiating the fuel for one cycle, some of the rods are removed from the irradiated assemblies and taken to a laboratory for PIE. Additional rods will be removed after the second, third, and fourth cycles (if the chosen reactor has a third and fourth cycle), and PIE will be performed to confirm that the structulal integrity of the MOX fuel, cladding, and assembly materials is maintained and that the computer codes accurately predict the fuel performance and evolution of fission products.

Figure 2 shows the anticipated schedule for the LA program relative to the plutonium disposition mission. Los Alamos National Laboratory (LANL) is currently developing the processes necessary to fabricate MOX fuel. The U.S. Department of Energy Office of Fissile Materials Disposition (DOE-MD) plans to choose a consortium before the end of 1998 to disposition excess plutonium using reactors, at which time this consortium will choose the DOE site(s) and associated facilities to fabricate the LA MOX fuel. At that same time the consortium will begin design, licensing, and construction of the mission MOX fuel fabrication facility. The fabrication process used for the LAs will be as close as possible to that of the MOX fabricator in the consortium. Fatrication of the LA MOX fuel will begin in late 2002. The first LAs [shown as lead-test assemblies (LTAs) in Fig. 2] will be available for insertion in a commercial reactor in late 2003. PIE will begin 6 months after completion of the first reactor cycle with results available by the end of the second LA reactor cycle. Af er two LA cycles (18-24 months per cycle), the mission MOX fuel fabrication will begin if the PIE produces satisfactory confirmation of fuel performance. PIE will be done after each LA reactor cycle to ensure that fuel performance meets or exceeds expected results. Table 1 provides the schedules associated with the design, modification, operation, decontamination and decommissioning (D\&D), and/or conversion of the LA MOX fuel fabrication facility. Table 2 provides the time frames associated with the LA testing.

To maintain LA fabrication capability, should it be needed for any reason, the LA fuel fabrication facility will be maintained in standby for 4 years between the end of the facility's scheduled operation and its scheduled D\&D. During this time the capability to produce lead assemblies will be maintained.

A maximum of ten LAs will be produced to meet the LA program mission goals. Table 3 provides the anticipated quantities of constituent malerials that will be needed annually and in total to complete the LA program. Several assumptions were made to arrive at the quantities in Table 3, and these are listed in Table 4.

A total of four assemblies are anticipated to be required for use as LAs in the chosen mission reactor. It is possible a second set of four LAs will be needed for either a second reactor or for use in the same reactor. In addition, sufficient rods will tie produced to assemble two archive LAs.

A total of eight LA MOX fuel as:semblies will be temporarily stored in the LA fabrication facility until they are shipped to the reactors for irradiation. The rods for the two remaining assemblies, and possibly the MOX rods from four assemblies not used, will be retained in the LA shipping and storage area as archive rods. These archive rods will be used if needed as replacement rods in the reactor or they may be used for tests of the LA MOX fuel fabrication process. If they are not needed, or until they are needed, these rods will be stored at the LA MOX fuel fabrication facility until the end of that facility's mission. The LAs will then be shipped to the mission MOX fabrication facility for storage until the end of the Fissile Materials Disposition Program, at which time they will either be retained by the consortium as active rods, or irradiated in a mission reactor.

Due to the uncertainty associated with the final design of the LA MOX fuel, the assemblies may consist of either all MOX fuel rods or a combination of low-enriched uranium (LEU) and MOX rods. A bounding approach was taken in considering environmental impacts. The bounds that were considered for this report were based on the number of MOX fuel rods per assembly. A lower bound of one-third of the fuel rods being MOX rods results in the need to ship the remaining two-thirds of the required LEU rods to the LA fuel fabrication facility. The upper bound of all MOX rods in the assembly provides the bounding case for resource needs, safety considerations, accident analyses, and postirradiation examination. 


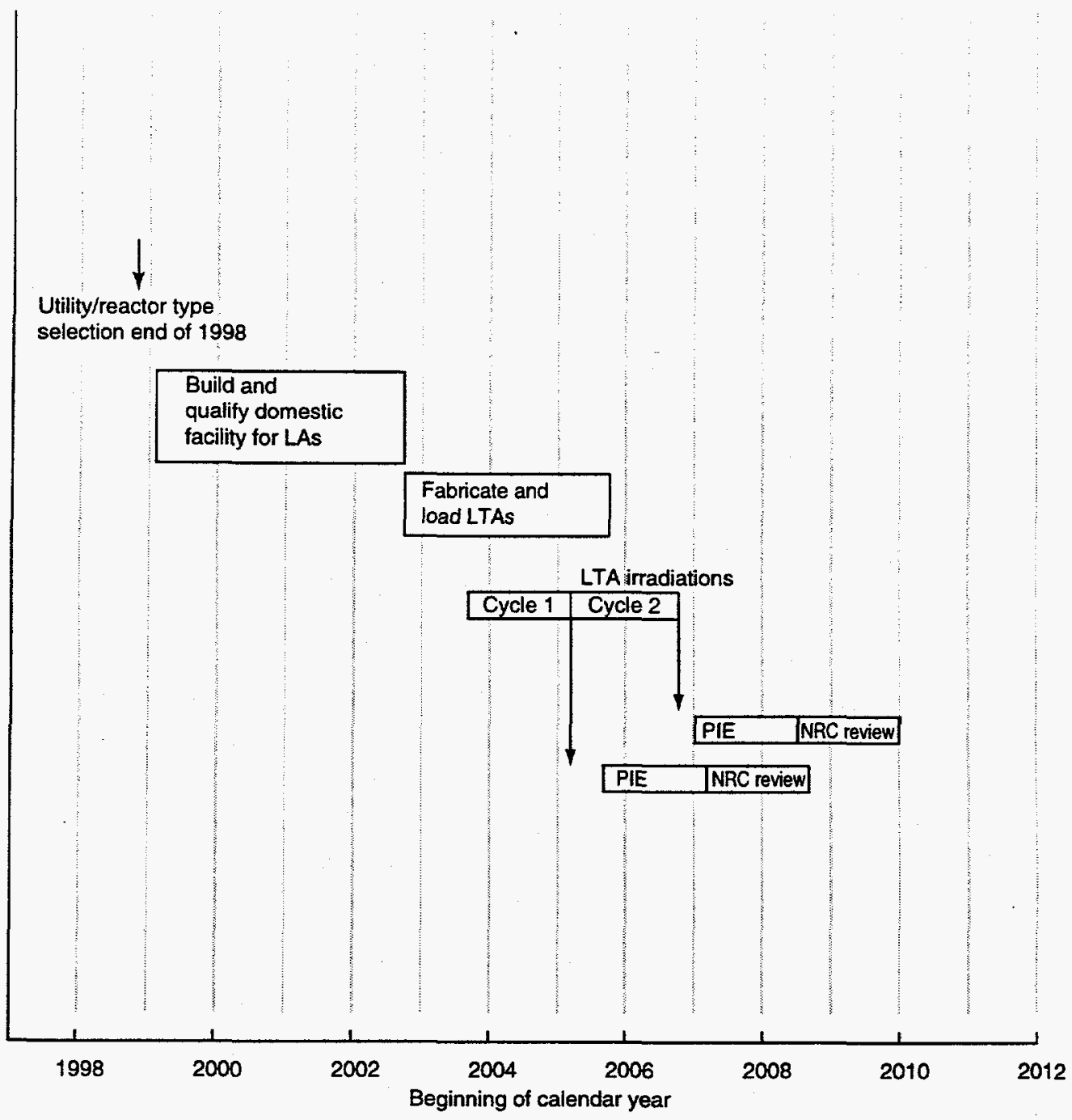

Fig. 2. LA program schedule. 
Table 1. LA fabrication facility schedule

\begin{tabular}{ll}
\hline \multicolumn{1}{c}{ Activity } & \multicolumn{1}{c}{$\begin{array}{c}\text { Time frame } \\
\text { (beginning and end) }\end{array}$} \\
\hline $\begin{array}{l}\text { Equipment procured } \\
\text { Facility design }\end{array}$ & June 2000-December 2001 \\
Facility permitting & February 1999-January 2001 \\
Facility modification & January 2000-January 2002 \\
Facility startup & January 2000-February 2002 \\
LA fabrication (operation) & February 2002-October 2002 \\
LA fabrication facility standby & October 2002-October 2005 \\
D\&D and/or convers on phase & October 2005-January 2010 \\
\hline
\end{tabular}

Table 2. LA testing schedule

\begin{tabular}{ll}
\hline \multicolumn{1}{c}{ Activity } & \multicolumn{1}{c}{ Time frame (beginning and end) } \\
\hline Irradiation & September 2003-October 2006 \\
Removal (cooldown) & $\begin{array}{l}\text { March 2005-October 2006 (6 months cooldown after removal } \\
\text { before PIE, March 2005-April 2007) }\end{array}$ \\
PIE & $\begin{array}{l}\text { September 2005-October 2008 (about 18 months for PIE for each } \\
\text { reactor bycle) }\end{array}$ \\
\hline
\end{tabular}

Table 3. LA. MOX fuel material requirements

\begin{tabular}{|c|c|c|c|c|c|}
\hline Material & $\begin{array}{l}\text { Startup } \\
\text { requirement }\end{array}$ & $\begin{array}{c}\text { Startup } \\
\text { scrap/recyclable }\end{array}$ & $\begin{array}{l}\text { Maximum } \\
\text { annual } \\
\text { requirement }\end{array}$ & $\begin{array}{l}\text { Maximum } \\
\text { annual scrap/ } \\
\text { recyclable }\end{array}$ & $\begin{array}{l}\text { Total } \\
\text { quantity }\end{array}$ \\
\hline $\begin{array}{l}\text { Plutonium, } \mathrm{kg} \\
\text { heavy metal (HM) }\end{array}$ & 21 & 13 & 120 & 20 & 321 \\
\hline $\begin{array}{l}\text { Depleted uranium, } \\
\text { kg HM }\end{array}$ & 867 & 250 & 2,400 & 400 & 6,867 \\
\hline Pellets & 221,760 & & 532,224 & & $1,552,320$ \\
\hline Rods & 440 & & 1,162 & & 3,344 \\
\hline Bundles & & & 4 & & 10 \\
\hline
\end{tabular}

Note: In the event LEU rods are used in place of some MOX rods in the assembly, the total quantities of plutonium will be reduced by the amount of LEU introduced. The maximum contribution of LEU rods is twothirds of the total assembly rods. 
Table 4. Assumptions made to determine LA MOX fuel material requirements

1. Material and process requirements are based on producing pressurized-water reactor (PWR) fuel.

2. $\mathrm{PuO}_{2}$ powder will meet the American Society for Testing and Materials (ASTM) specification C 757-90 as received.

3. Depleted $\mathrm{UO}_{2}$ powder will meet the ASTM specification as received.

4. Depleted $\mathrm{UO}_{2}\left(\right.$ no $\mathrm{PuO}_{2}$ ) will be used to perform all system shakedown tests before introducing plutonium.

5. Table 3 is in terms of $\mathrm{HM}$. The factor for converting $\mathrm{PuO}_{2}$ and depleted $\mathrm{UO}_{2}$ to $\mathrm{HM}$ is $88 \%$.

6. All waste plutonium will be canned and sent to the Immobilization Program for final disposition.

7. All plutonium scrap will be recycled using a dry process.

8. All liquid wastes generated are ancillary to the base process (i.e., laundry, mop water, etc.).

9. Sintering furnaces will stay at temperature during the entire 3-year mission and 1-year startup.

10. Sintering furnaces will be purged with a mixture of argon and $6 \%$ hydrogen at a rate of $10 \mathrm{~L} / \mathrm{min}$.

11. Powder glove boxes will be purged with nitrogen to reduce the potential for oxidizing $\mathrm{UO}_{2}$.

12. All calculated numbers have a precision of no more than two significant figures.

13. Homogenization of the $\mathrm{PuO}_{2}$ will be done at the LA fuel fabrication facility, as will gallium removal operations. 
Page Intentionally Blank 


\section{SITE MAP AND THE LA FACILITY DESCRIPTION}

The LA fabrication effort at Los Alamos National Laboratory (LANL) is proposed to take place at several different facilities, each of which are specially designed and equipped to handle different steps of the process. The fuel fabrication and rod loading/welding would be performed at Technical Area (TA) 55, more specifically in Plutonium Facility 4 (PF-4). The bundle assembly and inspection could be performed at any of a number of facilities, including the Radioactive Materials Research, Operations, and Demonstration Facility (RAMROD), the Chemistry and Metallurgy Research (CMR) Building at TA-3, or one of the Critical Assembly Building kivas at TA-18. Bundle storage is proposed to occur either in the bundle assembly area (i.e., RAMROD) or in the basement area of PF-4, and from there the bundles will be loaded onto safe secure transports (SSTs) for transport off-site. These and other facilities of interest (i.e., waste-handling facilities) are listed below, and Table 5 summarizes the functions proposed for each facility. Their locations with respect to other laboratory areas and the towns of Los Alamos and White Rock can be seen on Fig. 3.

\subsection{TA-55 AND PF-4}

TA-55, the plutonium facility complex, is one of the larger TAs at LANL. The facilities at TA-55 are located on a 16-ha (40-acre) site about $1.6 \mathrm{~km}(1 \mathrm{mile})$ southeast of TA-3. The primary research and development (R\&D) facility at TA-55 is the Plutonium Facility (PF-4). All plutonium entering or exiting TA-55 is processed at this facility, which is a two-story laboratory with a surface area of $\sim 14,000 \mathrm{~m}^{2}$ $\left(151,000 \mathrm{ft}^{2}\right.$ ). The main complex has five connected buildings (see Fig. 4): Administration Building (PF-1), Support Office Building. (PF-2), Support Building (PF-3), Plutonium Facility (PF-4), and Warehouse (PF-5). The PF-4 is classified as a Safeguards Category I and a Hazard Category II nonreactor nuclear facility and was built to comply with seismic standards for Safeguards Category I buildings. The ventilation system in the facility has four zones. The overall design concept for PF-4 separates the building into two halves; each half operates as a separate building with its own filtered exhaust stack. Various ongoing activities at PF-4 include plutonium recovery, fabrication of plutonium components, disassembly of weapons components, actinide processing, $R \& D$, processing of ${ }^{238} \mathrm{Pu}$, and especially the fabrication of ceramic-based reactor fuels.

Most of the activities for the LA fabrication effort are proposed to occur within PF-4. The operational fuel fabrication laboratories (Rooms 125 and 126) will be used with minor modifications to fabricate the LA fuel. These modifications are mainly equipment upgrades and include

- purchasing and installing production model blending and milling equipment in existing glove boxes, and

- purchasing and installing a ceramic pot-type batch, or pusher-type continuous sintering furnace in place of existing glove boxes.

Table 5. Potential functions for each facility

\begin{tabular}{|c|c|c|c|c|c|c|c|}
\hline Facility & $\begin{array}{c}\text { Pellet } \\
\text { fabrication }\end{array}$ & $\begin{array}{c}\text { Rod } \\
\text { fabrication }\end{array}$ & $\begin{array}{c}\text { Bundle } \\
\text { assembly }\end{array}$ & $\begin{array}{l}\text { Analytical } \\
\text { chemistry }\end{array}$ & $\begin{array}{c}\text { Waste } \\
\text { management }\end{array}$ & $\begin{array}{l}\text { Bundle } \\
\text { storage }\end{array}$ & Transportation \\
\hline TA-55/PF-4 & $\mathrm{X}$ & $\mathrm{x}$ & $\mathrm{X}$ & $\mathrm{X}$ & & $\mathrm{X}$ & \\
\hline TA-3/CMR & & & $\mathrm{X}$ & $\mathbf{x}$ & & $\mathbf{X}$ & \\
\hline TA-18/kivas & & & $\mathrm{X}$ & & & $\mathbf{X}$ & \\
\hline TA-50/RAMROD & & & $\mathrm{X}$ & & & & \\
\hline TA-50/WCRRF & & & $\mathrm{x}$ & & $\mathrm{x}$ & $\mathrm{X}$ & \\
\hline TA-54 & & & & & $\mathrm{x}$ & & \\
\hline Pajarito Road & & & & & & & $\mathrm{X}$ \\
\hline
\end{tabular}




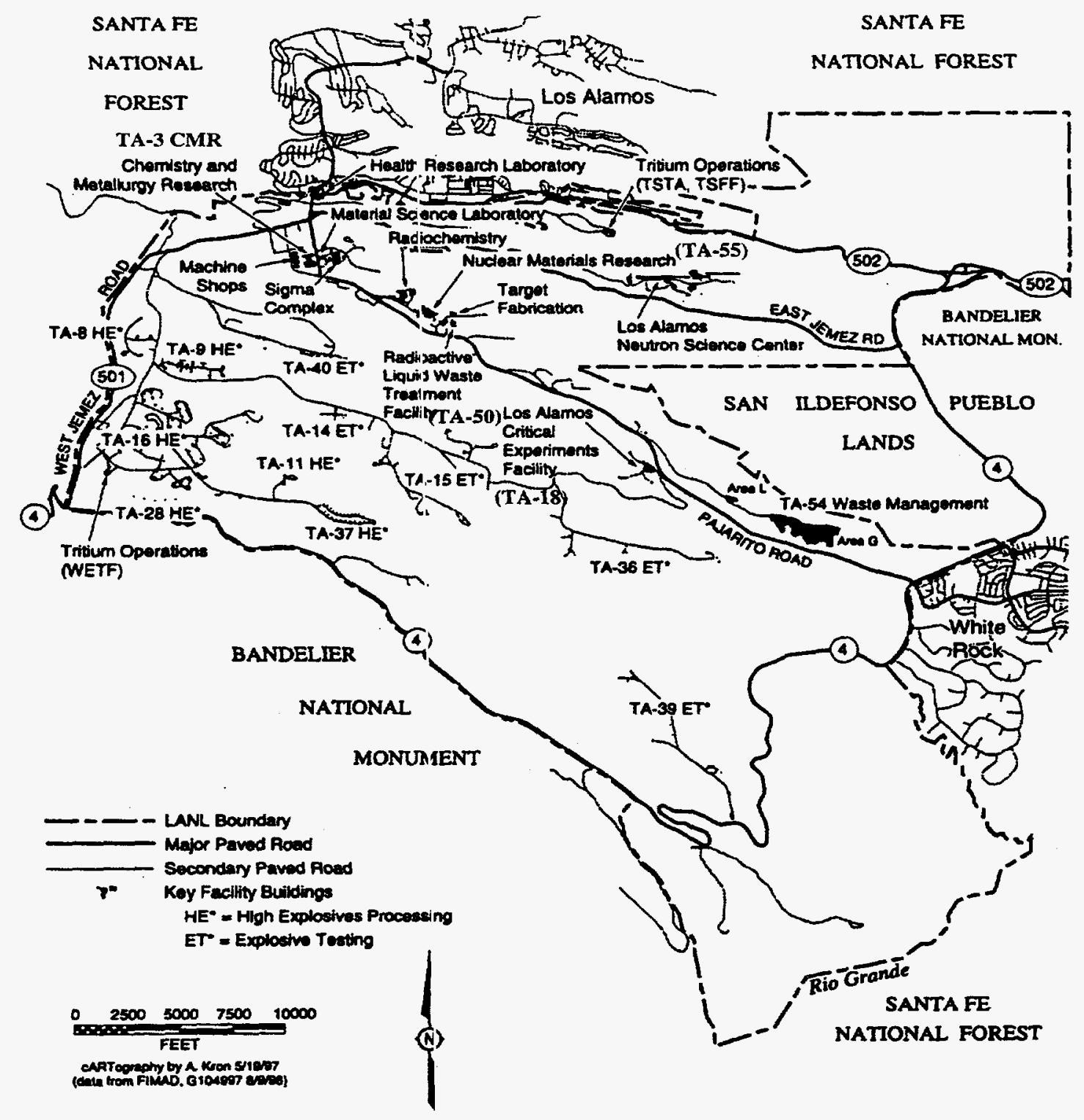

Fig. 3. Locations of LANL TAs. 


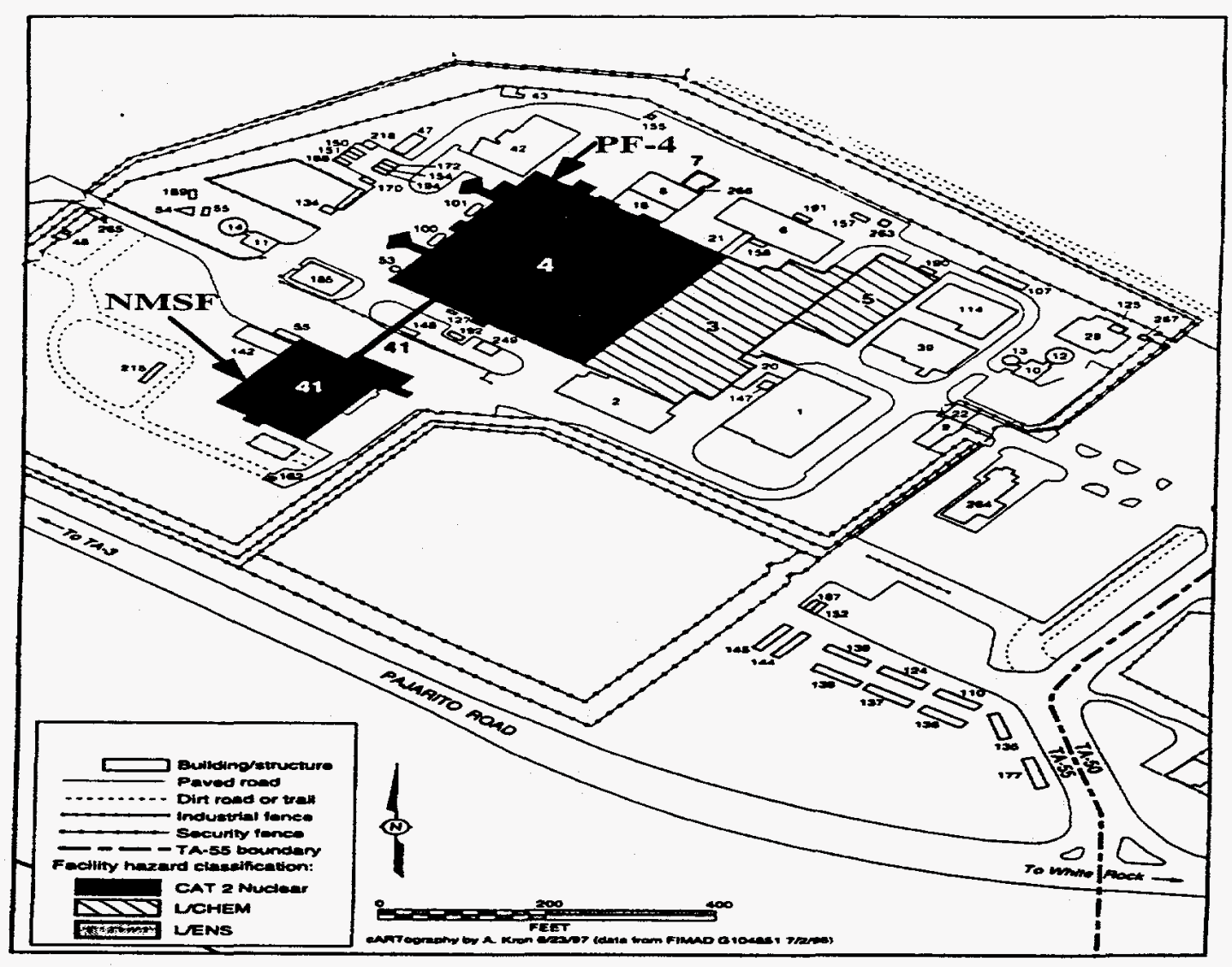

Fig. 4. Facilities at TA-55.

With the exception of the sintering furnace installation, each of the modifications is performed by removal of a glove box window or top. The sintering furnace installation will first require the removal of one existing glove box [including decontamination and decommissioning (D\&D)]. Where appropriate, new utility lines will be added, expected only for the sintering furnace and possibly the granulator.

Already planned upgrades to Room 124 (next-door to the fuel fabrication laboratories) could provide on-site analytical chemistry capability for the LA fabrication effort. It is most likely, however, that the majority of the analytical chemistry activities will take place in the already operational laboratories within the CMR Building. The rod loading and welding activities are also proposed for PF-4 in Room 201. For this effort, minor modifications will be needed. Four uncontaminated glove boxes would be removed, and two new glove boxes would be installed. The appropriate loading and welding equipment would be installed, along with helium leak check capability and rod storage racks.

Although the bundle assembly is proposed to take place elsewhere (i.e., RAMROD or CMR Building), it is assumed that the bundle storage could be done in PF-4, most likely in the basement area. Storage racks would be needed in the designated area. The SST shipments will most likely originate from PF-4, so some sort of bundle storage will be needed there in any case.

LANL requested an extensive evaluation of the seismic hazards for the entire laboratory site in accordance with DOE-STD-1024. ${ }^{1}$ Woodward-Clyde completed the Seismic Hazards Evaluation of the Los Alamos National Laboratory. ${ }^{2}$. This study involved extensive trenching throughout the site and specifically at TA-55. The result was a new evaluation basis seismic event that was used for the analyses in the TA-55 Final Safety Analysis Report (SAR), ${ }^{3}$ which was based on a $0.3 \mathrm{~g}$ peak ground acceleration with a broadband response spectrum (NUREG-0098). ${ }^{4}$ The seismic analysis of PF-4 and supporting facilities was performed in accordance with DOE-STD-1020.5 The structure, systems, and components, including glove boxes and their supports, were evaluated. Some seismic vulnerabilities were identified, and their 
consequences were evaluated. All seismic upgrades that were identified in the DOE safety evaluation report ${ }^{6}$ which approved the SAR (DOE 5480.23) ${ }^{7}$ and TSR (DOE 5480.22), ${ }^{8}$ have been completed.

The PF-4 ventilation system consists of numerous fans, filters, ductwork, and other equipment that provide ventilation, pressure control, and space temperature control for the interior of $\mathrm{PF}-4$. There are two primary air flow paths through PF-4. One primary air flow path provides ventilation for glove boxes, and the other provides ventilation for laboritories. Secondary flow paths are also associated with each of the primary paths. The primary flow paths ojerating together, along with their associated secondary flow paths, provide ventilation for PF-4. The glove box ventilation flow path is from the outside atmosphere through HEPA filters into the basement, from the basement through HEPA filters into the glove box system, and from the glove box system through HEPA filters to the outside atmosphere. The laboratory ventilation flow path is from the outside atmosphere through HEPA filters to the corridors on the laboratory floor, from the corridors into the laboratories, and from the laboratories through HEPA filters to the outside atmosphere. Air flow through these flow paths maintains pressure in PF-4 such that the basement is negative with respect to the outside, the laboratories are negative with respect to the outside, and the glove boxes are negative with respect to the laboratories. More information about this system can be obtained from Sect. 4.4.1 of the SAR for PF-4 (Ref. 3) (with respect to DOE standards and DOE Order 5480.23). No upgrades to this system are anticipated or are considered necessary to accommodate LA MOX activities.

The ventilation scheme is supportid by pressure differential indicators (PDIs) and maintained and controlled by pressure differential transmitters (PDTs) and pressure differential indicating controllers (PDICs). PDIs, located throughout the ventilation subsystems, provide local indication of the pressure differential across various components such as HEPA filters, cooling coils, and plenums. The PDIs are routinely monitored by facility personrel, and corrective action is taken when required. The pressure differential is controlled by a PDIC. The electronic signal from the PDT is transmitted to both the facility control system and to an electronic FDIC. The FDIC outputs a control signal to a pressure transducer to vary the position of a control damper to obtain and maintain the desired differential pressure.

PF-4 is separated into four main areas and the process rooms are also individually separated. Operators are trained to monitor themselves after every glove box entry (hands in gloves) and as they exit the individual process rooms. In addition, radiation monitors (both personnel and whole exterior body) are positioned at the exits of PF-4.

Air is removed from the glove boxes through individual 8-in.-diam HEPA filters mounted atop the glove boxes. The primary purpose of these filters is to minimize the contamination reaching the exhaust ductwork. The air from the glove boxes passes through plenums containing a minimum of three banks of HEPA filtration in series before being discharged to the exhaust stack. Essentially, PF-4 uses three levels of confinement: primary, secondary, and tertiary. They were designed to Atomic Energy Commission (AEC) manual, Chap. 6301, "General Design Criteria," which defines confinement in terms of

- primary confinement, the process enclosures and their ventilation subsystems;

- secondary confinement, the operating area compartments and their ventilation subsystems; and

- tertiary confinement, the structure and its ventilation subsystems. ${ }^{9}$

PF-4 has two discharge stacks of adequate height. Emissions data are monitored for radioactive species of concern and reported annually to the State of New Mexico and federal (DOE) organizations as appropriate. No deficiencies have been noted. An upgrade is being designed to comply with the new American National Standards Institute (ANSI) stack sampling requirements and to make use of the shrouded probe technology.

PF-4 has inert gas capability from tube trailers on the North dock and two 6,000-gal dewars with nitrogen and argon. Purification systems and oxygen monitoring capability are attached to glove boxes where necessary. Incoming air and recirctlated air pass through a moisture eliminator. Previous projects in $\mathrm{PF}-4$ involved extensive process developinent of mixed uranium/plutonium carbide and nitride fuel forms that required stringent atmosphere requirements and associated equipment.

Hazard and accident analysis as reported in the approved TA-55 Final Safety Analysis Report (FSAR $^{3}$ identified the confinement system, as a whole, as safety class. The accidents for which a safety class designation was made are earthquake, fire, and wind. The safety ventilation components of the confinement systems are designed to with stand the effects associated with each of these accidents. Seven subsystems were identified as safety significant: the ventilation system, the glove boxes, the criticality 
alarm system, the fire suppression system, the chemical storage tank berms, the vault racks and shelving, and a hydrogen detector on a specific glove box. All systems were analyzed for "Defense-in-Depth" and are discussed in the approved TA-55 FSAR (July 1996).

\subsection{TA-3 AND CMR BUILDING}

TA-3 (see Fig. 5) is LANL's main and largest TA, both in terms of the amount of land space and the number of personnel. It houses a variety of projects and contains a number of buildings/facilities, including the CMR Building (see Fig. 6). This building was designed within TA-3 as an actinide chemistry and metallurgy research facility. The main corridor contains seven wings that were constructed in 1952 . In 1960 , a new wing (Wing 9) was added for activities that must be performed in hot cells. The three-story building now has eight wings connected by a spinal corridor and contains a total of $51,000 \mathrm{~m}^{2}\left(550,000 \mathrm{ft}^{2}\right)$ of space. Each wing is associated with different activities. Containing hot cells and special nuclear material (SNM) vaults, it now is the only LANL facility with full capabilities for performing SNM analytical chemistry and materials science in support of the nuclear weapons program. It is currently designated as a Safeguards Category III and Hazard Category II nuclear facility, with some Safeguards Category I capabilities.

The CMR Building hosts a variety of activities, principally analytical chemistry, uranium processing, destructive and nondestructive analysis, actinide research and processing, fabrication, and metallography. Enough waste treatment and pretreatment is conducted within the facility to sufficiently meet waste acceptance criteria for both on- and off-site receiving facilities. In addition to being the primary location for many projects, these facilities are used to support various activities at other LANL locations.

Analytical chemistry capabilities involving the study, evaluation, and analysis of radioactive materials also reside at the CMR Building. These activities support various nuclear materials programs, many of which are performed at other LANL locations. Analytical activities include assay and determination of isotopic ratios of plutonium, uranium, and other actinides; major and trace elements in the materials;

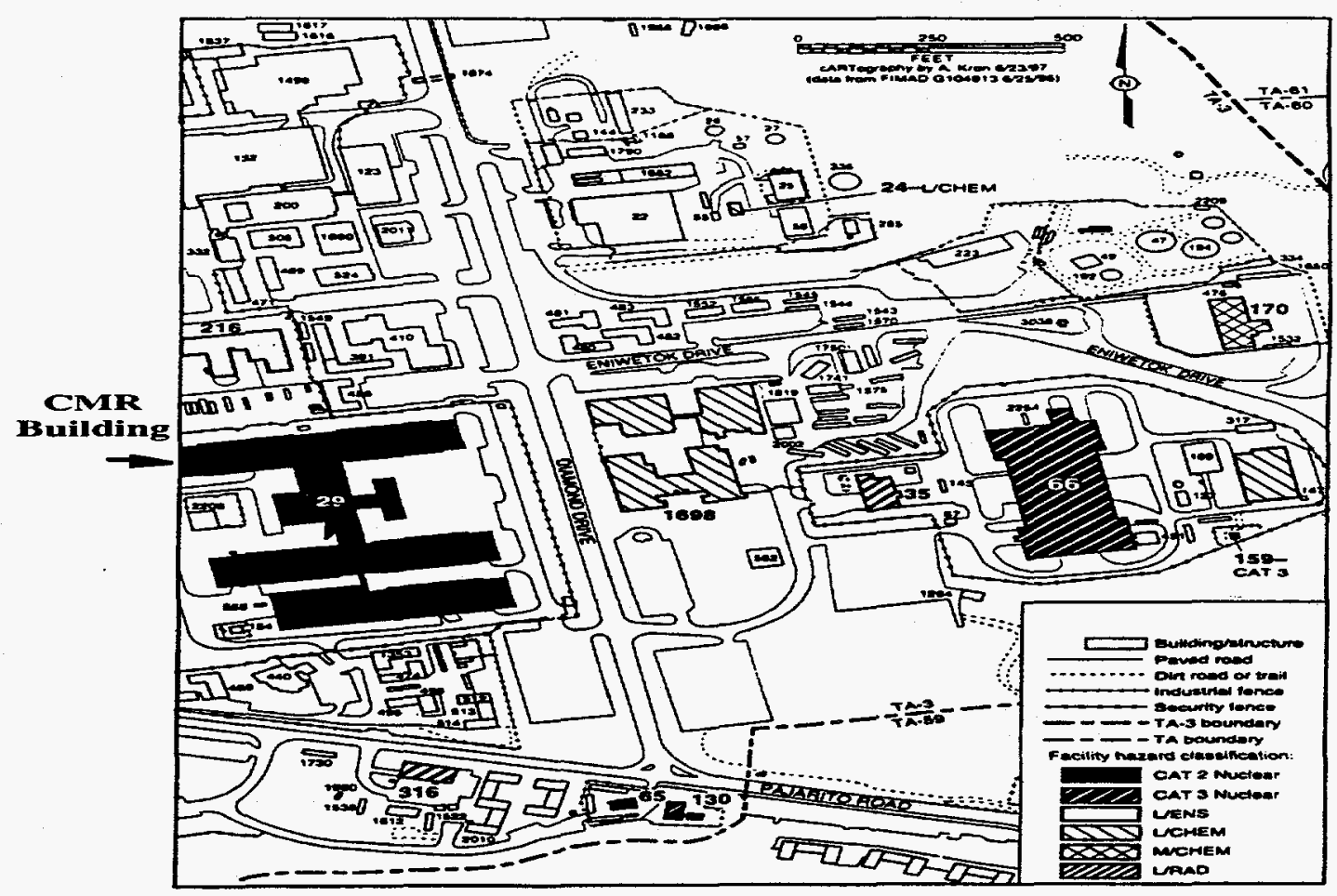

Fig. 5. Facilities in TA-3. 


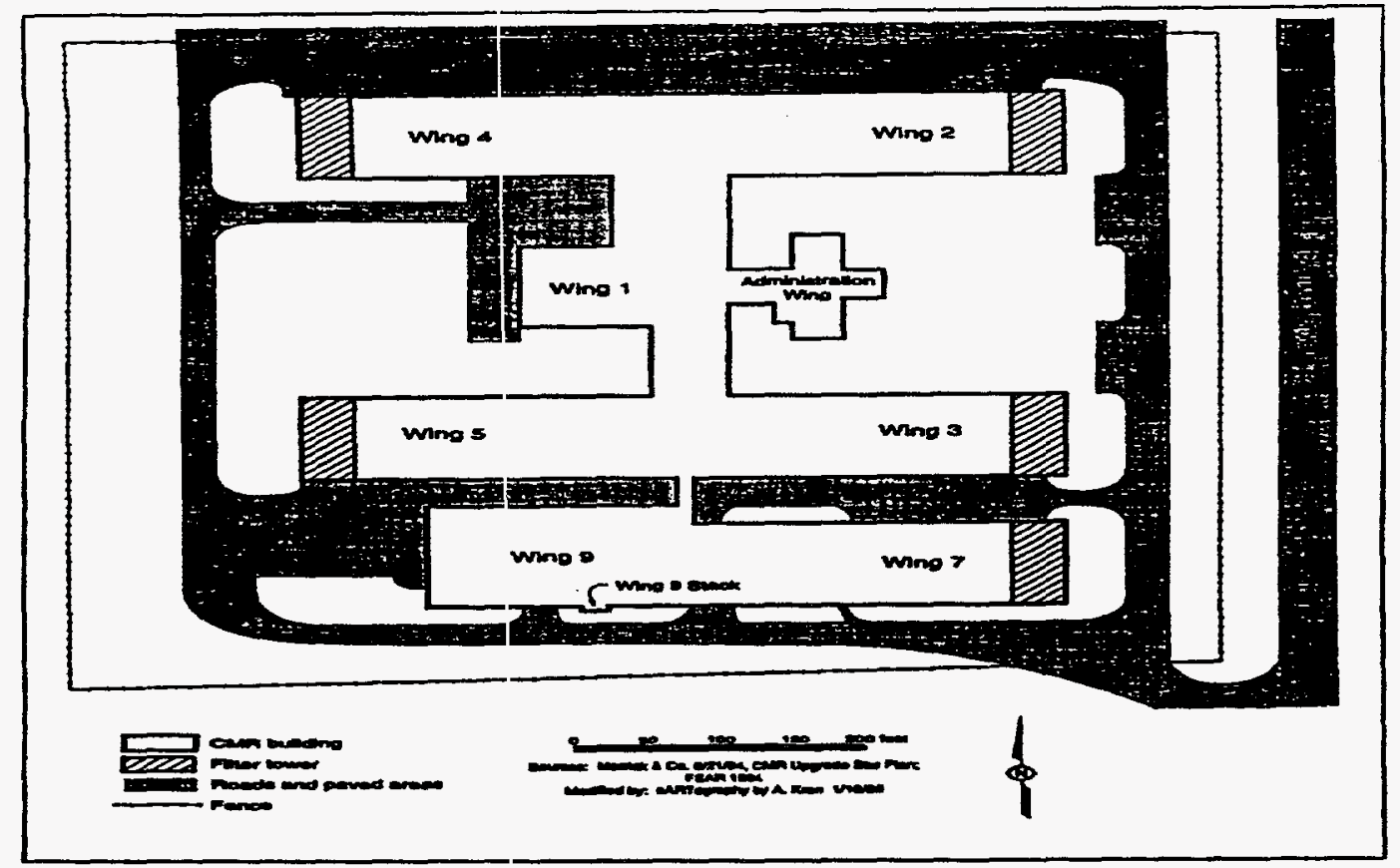

Fig. 6. CMR Building layout.

interstitial gases analysis; highly sersitive surface analysis techniques; and methods to determine environmentally important waste constituents on highly radioactive materials.

The high bay in Wing 9 of the CMR Building is an area proposed for the assembly of bundles and bundle inspection. For these activities, the only modifications needed would be the procurement and installation of necessary equipment, including rod storage racks, rod inspection equipment, bundle assembly device, bundle inspection equipment, and bundle storage racks. Only minor structural modifications are expected, mainly to accommodate electrical power needs for the new equipment. Bundle storage might be an option in the CMR Facility, but it will most likely be restricted to a temporary basis while bundles are awaiting transport to IF-4. The CMR facilities will also most probably be the location of many of the analytical chemistry activitits for this project.

\subsection{TA-18}

Another facility being considered for the assembly of fuel rods into bundles is the Los Alamos Critical Experiments Facility (LACEF), or TA-18, which is located in arid Pajarito Canyon about $6.4 \mathrm{~km}$ (4 miles) southeast of TA-3 on Pajarito Foad (see Sect. 2.6). LACEF has operated since 1946 and is one of the last general-purpose nuclear experimental facilities in the United States. Its activities include national security programs, such as the Nuclear Emergency Search Team, Strategic Defense Initiative research, and Strategic Arms Reduction Treaty verification research; and the development of instrumentation for nuclear waste assay and high-explosives detection. The current primary purposes of LACEF are the design, construction, R\&D, and application of critical experiments as well as teaching and training for criticality safety and other applications of radialion detection and instrumentation. TA-18 is a restricted area containing many security fences and extra layers of safeguards and security (S\&S) protection. Four buildings within TA-18 are Hazard Category III nuclear facilities; these include the Critical Assembly Buildings Kivas 1, 2, and 3 (see Fig. 7) and the Hillside Vault. These three kivas are classified as Safeguards Category I. Each kiva is surrounded by security fences and additional S\&S precautions. Each 


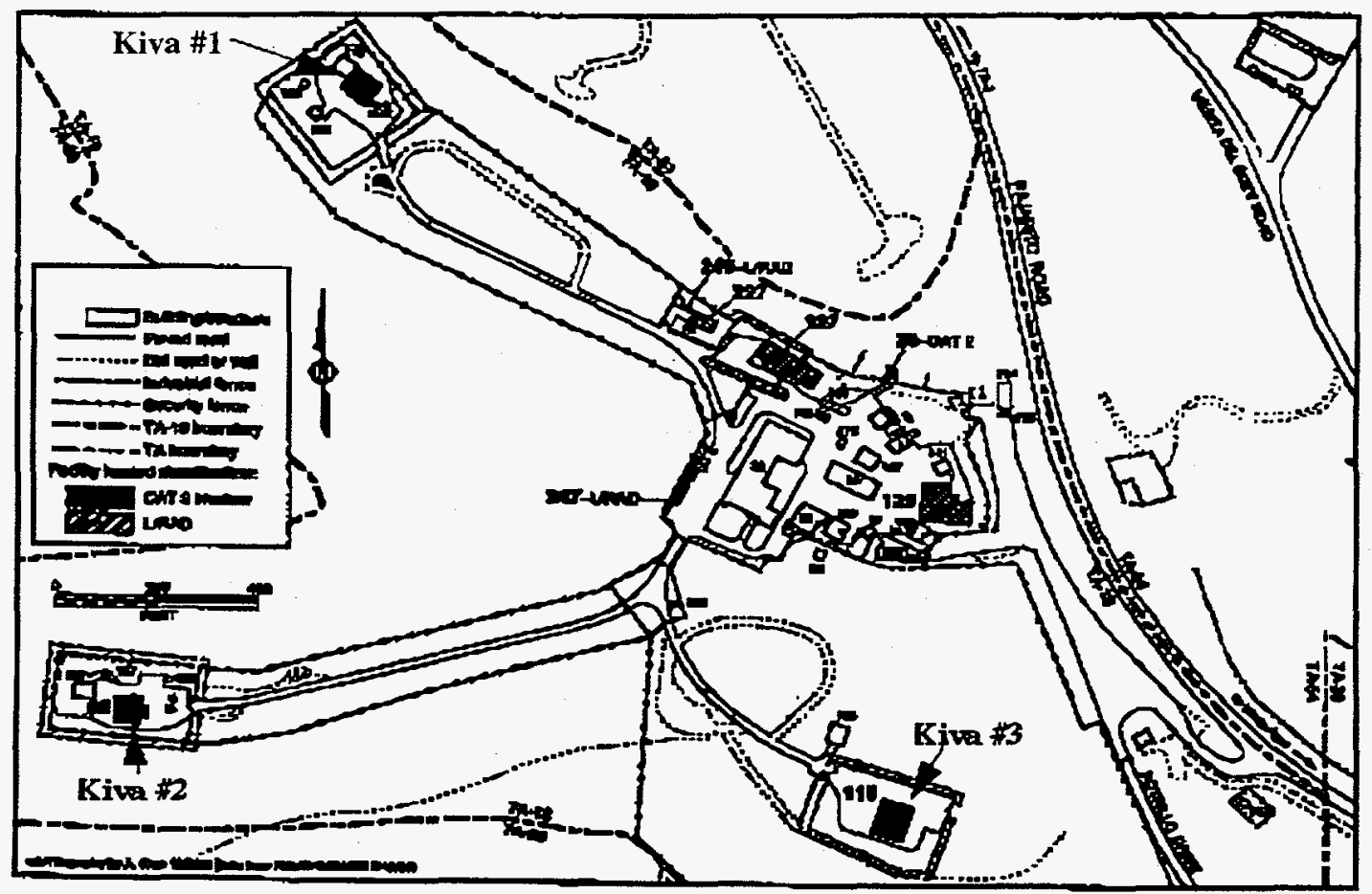

Fig. 7. Facilities at TA-18.

kiva has metal lockers used to store spent nuclear fuel containers, and load limits are placed on the vaults. These vaults can only be accessed from the entrance to the kiva. Kiva 1 is $134 \mathrm{~m}^{2}\left(1440 \mathrm{ft}^{2}\right)$ in area, Kiva 2 is about $162 \mathrm{~m}^{2}\left(1740 \mathrm{ft}^{2}\right)$ in area, and Kiva 3 has an area of $\sim 482 \mathrm{~m}^{2}\left(5184 \mathrm{ft}^{2}\right)$. Kiva 3 contains the most shielding of the three because it is located closest to occupied buildings, while Kivas 1 and 2 do not require as much shielding because they are located farther away.

It is proposed that one of these kivas may be used to assemble and inspect fuel bundles for the LTAs. The modifications described in Sect. 2.2 for bundle assembly and inspection are expected to be similar for use of the kivas, consisting mainly of equipment and power supply installation.

\subsection{TA-50}

TA-50 is a laboratory waste management site located near the center of the laboratory on 25 ha (62 acres) of land. The site includes 33 waste management structures such as trailers, tanks, and storage sheds, as well as 4 buildings (see Fig. 8). The following waste activities take place at TA-50: radioactive liquid waste treatment; decontamination of respirators, equipment, instruments, vehicles, and other waste items; size reduction of transuranic (TRU) wastes; and characterization of TRU wastes. The facilities are capable of storing and disposing of both solid and liquid low-level radioactive waste (LLRW), low-level mixed waste (LLMW), TRU waste, and hazardous waste. Major facilities in the area include the Radioactive Liquid Waste Treatment Facility (RLWTF); the Waste Characterization, Reduction, and Repackaging Facility (WCRRF); and the Radioactive Materials Research, Operations, and Demonstration (RAMROD) Facility.

RAMROD has a high bay equipped with a five-ton mobile crane with a 25 -ft clearance. Ample floor space exists ( 40 by $80 \mathrm{ft}$ ) for it to be considered a bundle assembly area option, and there is direct but securable access to a loading dock. An additional room in the facility that could be used has a similar high ceiling and 30- by 40 -ft floor space but would require a mobile derrick to be installed for lifting. This would require a simple temporary modification. Shops are available in the building if needed. The building 


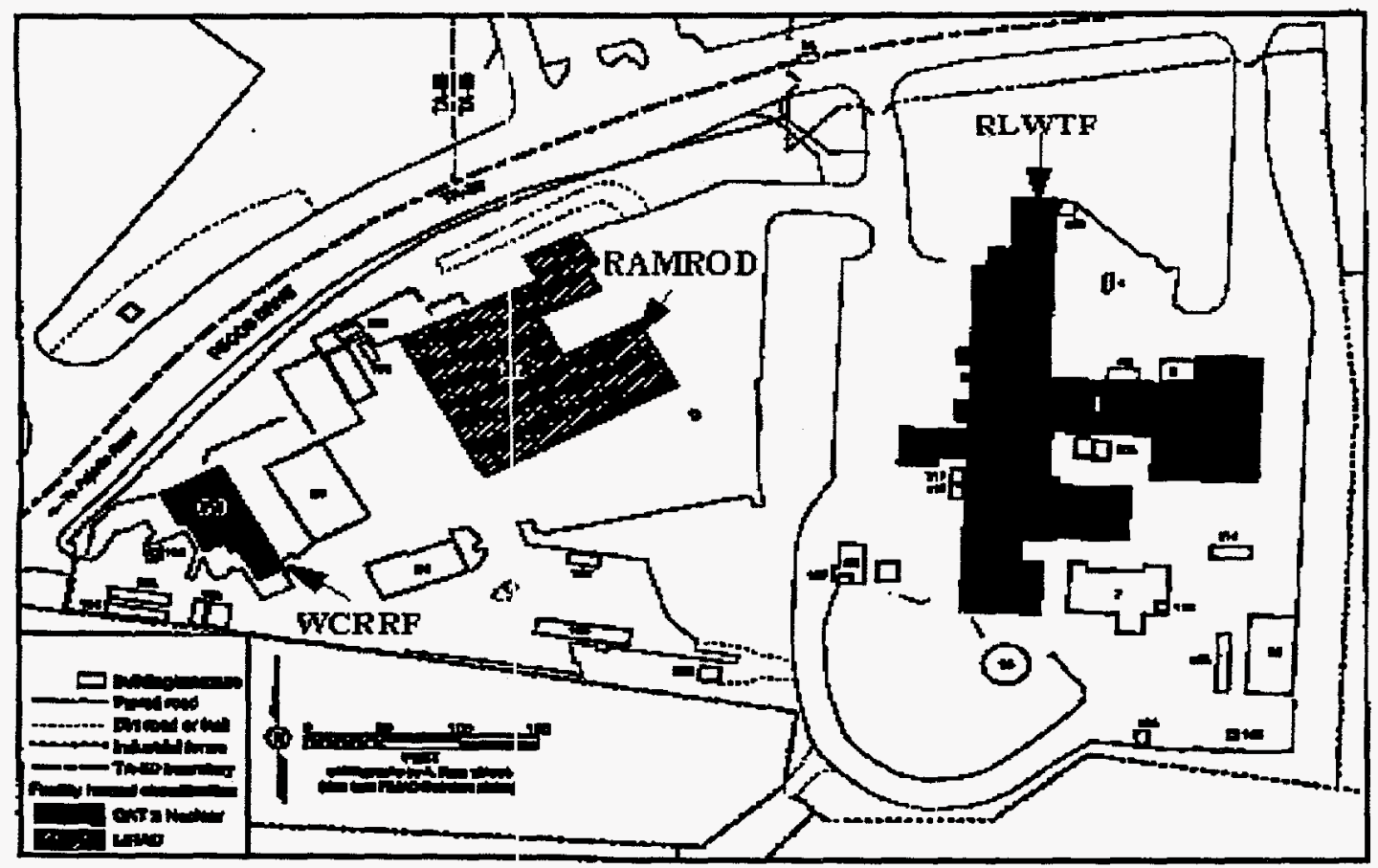

Fig. 8. Facilities at TA-50.

is equipped with a large HEPA filter bank. The facility is uncontaminated. The portion of RAMROD of interest is currently idle, and no other uses are planned for the period of interest. Although no seismic data currently exist about RAMROD, its SAR is currently being modified to include it.

Special lines and a concrete vault exist to allow acid and caustic radioactive liquid wastes from TA-55 (containing relatively high amounts of americium and plutonium) to be treated and pretreated at TA-50. The aqueous waste from radioactive activities and other nonhazardous aqueous chemical wastes at the CMR Building are also discharged into a network of drains and transported to TA-50 for treatment and disposal. After treating solid LLRW and TRU wastes, they are packaged to be transported to TA-54 (see Sect. 2.5) for retrievable storage until they can be shipped to a long-term storage facility. Three buildings in TA-50 are designated as Hazard Category II nuclear facilities: the RLWTF, RAMROD, and the WCRRF. The acid and caustic wastes generated at TA-55 are transported to the RLWTF. TRU wastes are packaged at the WCRRF to be transported to TA-54. The RAMROD facility is also a candidate Hazard Category II nuclear facility, but instead it currently performs combustion-based volume reduction and chemical stabilization of TRU-contaminated solid wastes and polychlorinated biphenyls as well as other waste streams.

The TA-50 facilities will be used for some waste management functions of this project. The WCRRF and RAMROD buildings are also possible candidates for the bundle assembly and inspection activities. No modifications are expected for this facility to accommodate the LA fabrication effort in terms of waste management, and the minor modifications described in Sect. 2.2 would apply for bundle assembly.

\subsection{TA-54}

Also one of the largest laboratory facilities, TA-54 is the main location for solid radioactive and hazardous chemical waste management and disposal. It has been active since 1957 and is predicted to remain open in the future. The facilities in TA-54 are grouped into various designated regions, including Areas G, H, J, and L (see Fig. 9). Area $1 \mathrm{G}$ is the low-level waste (LLW) management area. Area H is a Resource Conservation and Recovery Act (RCRA) site previously used to dispose of radioactive wastes 


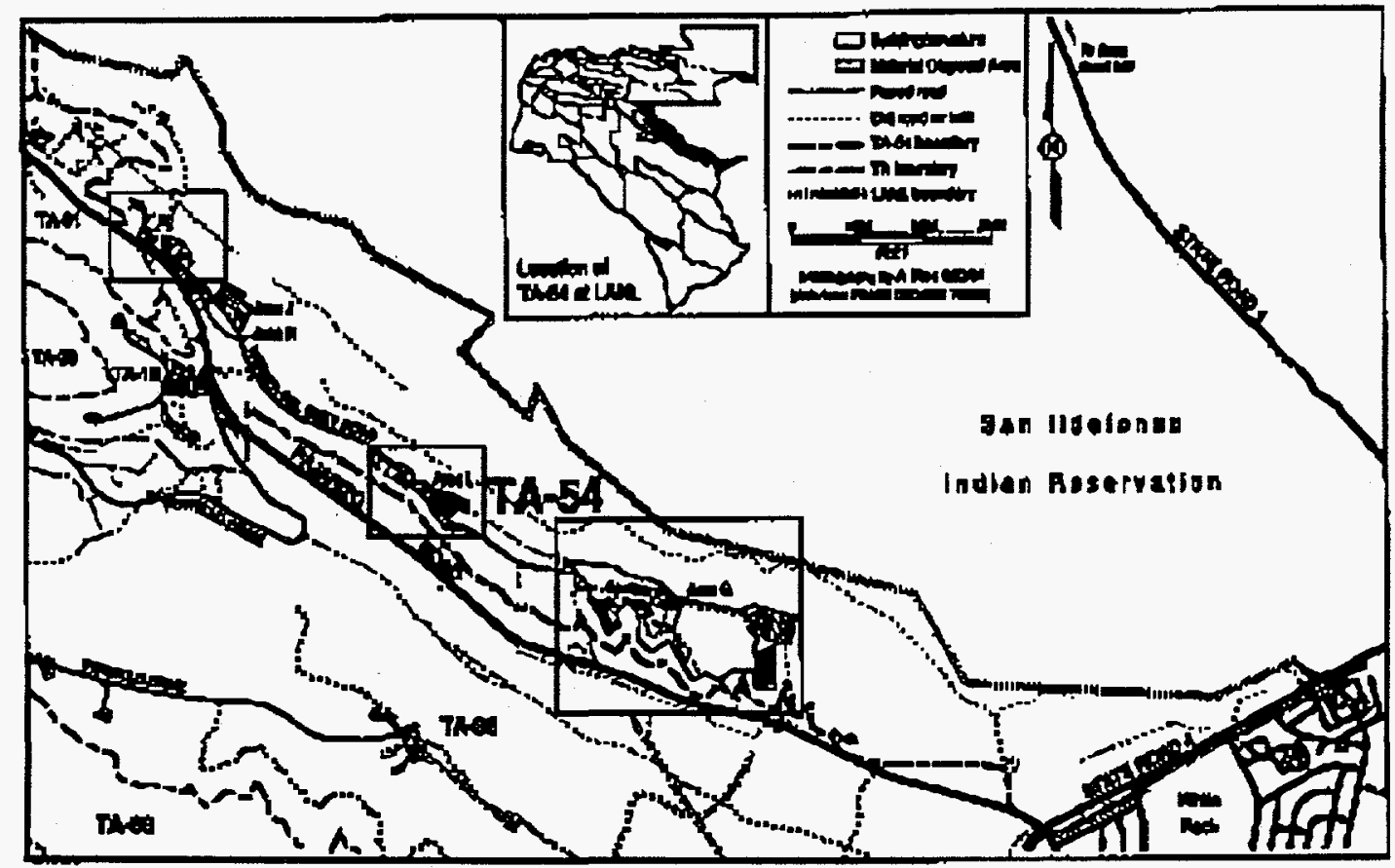

Fig. 9. TA-54.

(until 1986), Area $J$ is a classified solid and nonhazardous waste management site, and Area $L$ is the location of chemical waste management activities. Area $G$ will be used to handle wastes from MOX fuel fabrication. The solid LLW and TRU wastes typically packaged at TA-55 or TA-50 will be shipped to Area G.

TA-54 is an environmentally prominent TA because of its location. The northern boundary of TA-54 is $4.8 \mathrm{~km}$ ( 3 miles) long and separates LANL from San Ildefonso Pueblo land. It also borders the town of White Rock. TA-54 consists of 120 buildings; 101 contain waste management personnel and operations. Area $G$ expands over 25 ha (63 acres) on the 380 -ha (940-acre) site of TA-54. Waste management units within Area G include various LLW disposal pits and waste storage and disposal shafts (most of them closed), TRU waste pads and storage domes (may include LLW), a facility for decontaminating waste containers and contaminated equipment, two LLW compactor facilities, and an administrative support building that houses a locker room and decontamination shower. All of Area G is considered to be a Hazard Category II nuclear facility.

The TA-54 facilities will be used for solid waste management. No modifications are expected for this facility to accommodate the LA fabrication effort.

\subsection{PAJARITO ROAD}

This is a DOE-owned and -controlled roadway that connects the five aforementioned facilities. Most shipments of nuclear materials must be transported on this road, although shipments of rods to RAMROD for bundle assembly may occur on a LANL internal road. Because of the security and radiation risks of such shipments, this road is closed between the participating facilities when any such shipments occur. Thus, even though this road is generally open to the public, it may be closed by DOE at any time to accommodate transport of hazardous or other materials requiring security or safety precautions. No. modifications are expected for this facility to accommodate the LA fabrication effort. 
Page Intentionally Blank 


\section{PROCESS DESCRIPTIONS}

\subsection{PROCESS FLOW DIAGRAM}

A process block flow diagram is provided in Fig. 10. Assumptions for the process were given in Table 4. Figure 10 provides the total quantity of HM throughput that is anticipated at each step of the process for an entire year of operations after the facility reaches steady state.

To achieve a state of reliable operations for the new facility, cold startup and hot startup phases are anticipated to be necessary. Table 6 provides the anticipated material requirements for each phase of the startup and operations for the LA MOX fuel fabrication facility. The cold startup consists of using only depleted $\mathrm{UO}_{2}$ in the fuel fabrication process to develop acceptable processing steps.

Hot startup consists of using the final MOX fuel blend to determine that each processing step meets acceptable standards of fuel quality and repeatability. This phase of startup is anticipated to require at least 6 months.

\subsection{WASTE MANAGEMENT FLOW DIAGRAMS}

Figure $11(a)$ and $(b)$ are simplified flow diagrams that indicate how all forms of waste from the LA MOX fuel fabrication facility will be handled and disposed. These flow diagrams are generic examples of how waste will be handled for each site. Of course, each site will have some site-specific variations from the given flow diagrams, but for the purposes of this study the given material flow diagrams should be adequate.

For LANL, liquid LLW will be processed at the liquid LLW treatment facilities at TA-50, solid LLW will be disposed of underground in Area G of TA-54, and solid TRU waste will be stored in Area G aboveground on dome-covered pads with final disposal at WIPP. 


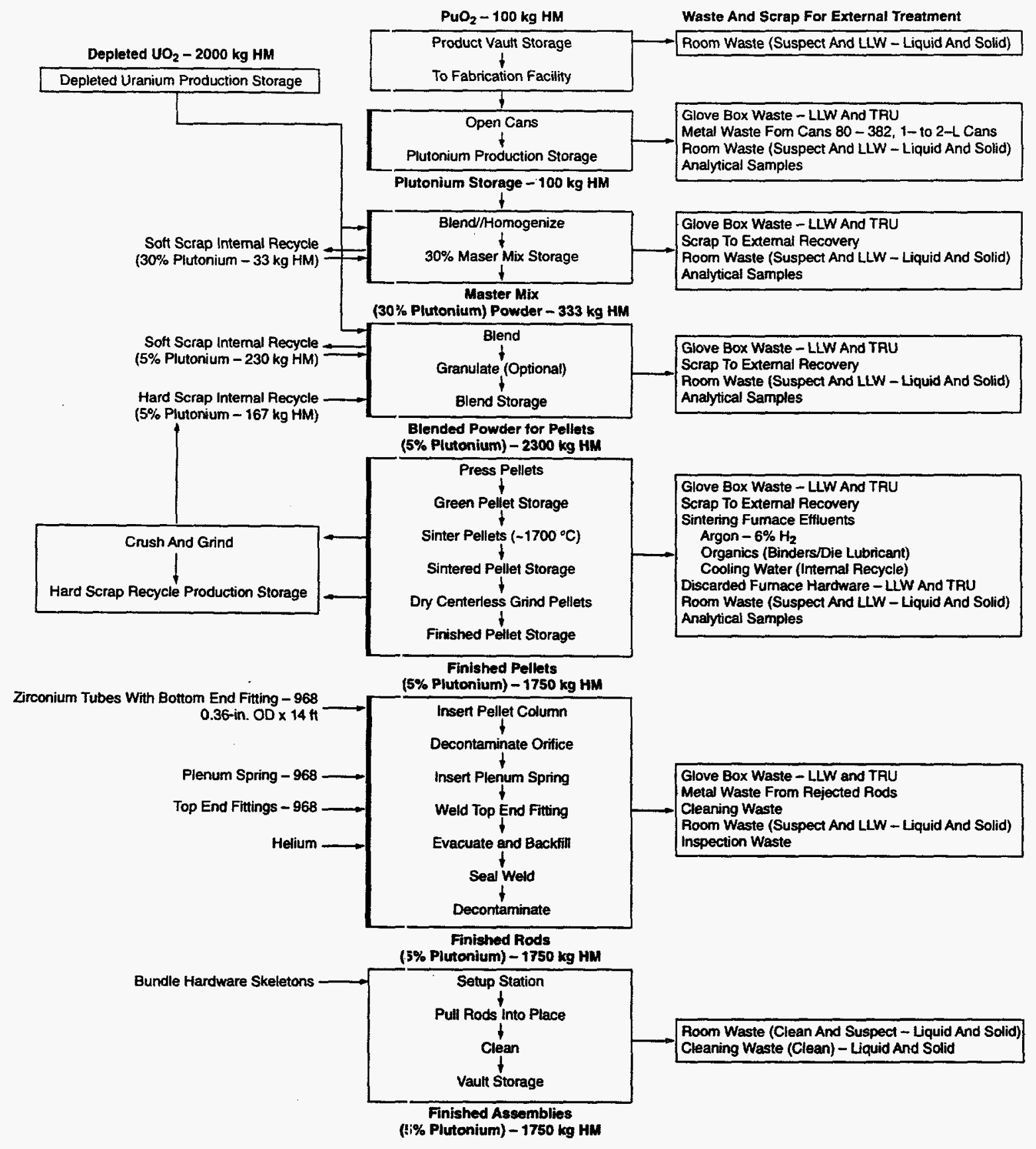

Note: 1 . Heavy borders are glove box process operations.

2. A total of $20 \%$ of pellets will be recycled.

Fig. 10. LA MOX fuel flow sheet outline with annual throughputs. 
Table 6. LA MOX fuel fabrication requirements

\begin{tabular}{|c|c|c|c|c|c|c|c|c|c|c|}
\hline & \multirow[b]{2}{*}{ Units/bundle } & \multicolumn{2}{|c|}{ Product produced $^{a}$} & \multirow[b]{2}{*}{$\begin{array}{c}\text { Cold } \\
\text { startup }\end{array}$} & \multirow[b]{2}{*}{$\begin{array}{l}\text { Hot startup } \\
\text { (6 months) }\end{array}$} & \multicolumn{4}{|c|}{ Production capacity required ${ }^{a}$} & \multirow[b]{2}{*}{ Total } \\
\hline & & $\begin{array}{l}\text { Output- } \\
3 \text { years }\end{array}$ & $\begin{array}{l}\text { Output- } \\
1 \text { year }\end{array}$ & & & $\begin{array}{l}\text { Rejection } \\
\text { rate }^{b}\end{array}$ & $\begin{array}{l}\text { Capacity/ } \\
3 \text { years }\end{array}$ & $\begin{array}{l}\text { Capacity/ } \\
1 \text { year }\end{array}$ & $\begin{array}{c}\text { Capacity/d } \\
(200 \mathrm{~d} / \text { year })\end{array}$ & \\
\hline \multicolumn{11}{|l|}{ Base requirements and assumptions } \\
\hline Bundles/year [pressurized-water reactor (PWR) $17 \times 17$ ] & & 10 & 3 & & & $0 \%$ & 10 & 3.3 & & 10 \\
\hline Rods & 264 & 2,640 & 880 & 220 & 220 & $10 \%$ & 2,904 & 968 & 5 & 3,344 \\
\hline Pellets $(0.327$-in. diam $\times 0.4 \mathrm{in.} \times 14 \mathrm{ft})$ & 110,880 & $1,108,800$ & 369,600 & 110,880 & 110,880 & $20 \%$ & $1,330,560$ & 443,520 & 2,218 & $1,552,320$ \\
\hline \multicolumn{11}{|l|}{ Plutonium and depleted uranium required } \\
\hline Plutonium (5\% in depleted uranium), $\mathrm{kg} \mathrm{HM}^{c}$ & 25 & 250 & 83 & & 21 & $20 \%$ & 300 & 100 & 0.5 & 321 \\
\hline Depleted uranium, $\mathrm{kg} \mathrm{HM}$ & 500 & 5,000 & 1,667 & 450 & 417 & $20 \%$ & 6,000 & 2,000 & 10 & 6,867 \\
\hline Total plutonium + depleted uranium, $\mathrm{kg} \mathrm{HM}^{c}$ & 525 & 5,250 & 1,750 & 450 & 438 & $20 \%$ & 6,300 & 2,100 & 11 & 7,188 \\
\hline \multicolumn{11}{|l|}{ Scrap generation } \\
\hline Total scrap depleted uranium, $\mathrm{kg} \mathrm{HM}$ & & & & 450 & & & & & & $450^{d}$ \\
\hline $\begin{array}{l}\text { Total scrap plutonium (mixed with depleted uranium), } \\
\text { kg HM }\end{array}$ & & & & & 13 & & 51 & 17 & 0.1 & $64^{d}$ \\
\hline $\begin{array}{l}\text { Total scrap depleted uranium (mixed with plutonium), } \\
\text { kg HM }\end{array}$ & & & & & 250 & & 1,000 & 333 & 2 & 1,250 \\
\hline \multicolumn{11}{|l|}{ Recycle and recovery scrap and waste quantities } \\
\hline $\begin{array}{l}\text { Recycled hard scrap } e^{e} \text { (mixed with depleted uranium), } \\
\text { kg HM }\end{array}$ & & & & & 6.25 & & 25 & 8 & & 31 \\
\hline $\begin{array}{l}\text { Recycled hard scrap depleted uranium (mixed with } \\
\text { plutonium), kg HM }\end{array}$ & & & & & 125 & & 500 & 167 & & 625 \\
\hline $\begin{array}{l}\text { Scrap plutonium to recovery (mixed with depleted } \\
\text { uranium), } \mathrm{kg} \mathrm{HM}\end{array}$ & & & & & 5 & & 21 & 7 & & 26 \\
\hline $\begin{array}{l}\text { Scrap depleted uranium to recovery (mixed with } \\
\text { plutonium), kg HM }\end{array}$ & & & & & 100 & & 400 & 133 & & 500 \\
\hline Waste plutonium $f$ (mixed with depleted uranium), $\mathrm{kg} \mathrm{HM}$ & & & & & 1.25 & & 6 & 2 & & 7 \\
\hline Waste depleted uranium (mixed with plutonium), $\mathrm{kg} \mathrm{HM}$ & & & & & 25 & & 100 & 33 & & 125 \\
\hline \multicolumn{11}{|l|}{ Waste volumes } \\
\hline Volume of transuranic (TRU) waste generated, $g^{g} \mathrm{~m}^{3}$ & & & & & 10 & & 120 & 40 & 0.2 & 130 \\
\hline Volume of low-level waste (LLW) generated, $\mathrm{m}^{3}$ & & & & 10 & 10 & & 120 & 40 & 0.2 & 140 \\
\hline Volume of mixed LLW generated, $\mathrm{m}^{3}$ & & & & 0.4 & 0.4 & & 3 & 1 & & 4 \\
\hline Volume of liquid LLW generated, L & & & & 40,000 & 40,000 & & 480,000 & 160,000 & 800 & 560,000 \\
\hline Volume of liquid TRU generated, $L$ & & & & & 50 & & 600 & 200 & 1 & 650 \\
\hline Volume of nonhazardous solid, $\mathrm{m}^{3}$ & & & & 650 & 650 & & 3,900 & 1,300 & & 5,200 \\
\hline Volume of nonhazardous sanitary liquid, $\mathrm{L}$ & & & & 800,000 & 800,000 & & $4,800,000$ & $1,600,000$ & & $6,400,000$ \\
\hline
\end{tabular}

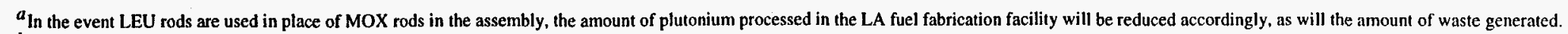

$b_{\text {Assumed that pellets in rejected rods can be reused. }}$

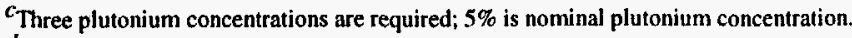

${ }^{d}$ Total uranium and plutonium scrap will be sent to the immobilization alternative for disposition.

${ }^{e}$ Hard scrap is from centerless grinding of pellets and rejected sintered pellets; $50 \%$ of hard scrap is assumed to be recycled. Soft scrap, consisting of off-specification powder blends, will be recycled within process line and is not considered in this table.

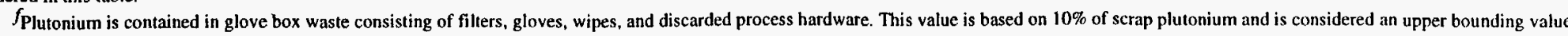

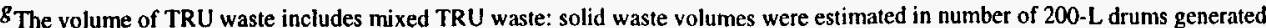


ORNL-DWG 97.2856 EFG

Monprocess Liquid Waste (Aqueous)

Sanitary Waste From All Facilities

Spent Cooling Water From Fazilities

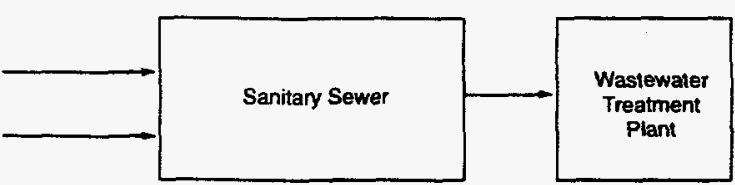

Nonprocess Solid Waste

Room Trash, Garbage, And Similar Solid iNaste

Send to Landiil

(On-Or Off-site)

\section{Liquid Radioactive Waste}

Liquid Low-Level Radioactive Waste (LI.LW)

LLLW Processing (1)

Solid Radioactive Waste

Radiaactive Solid Waste (2)

Solid Low-Level Radioactive Waste (LLIV)

LWW Processing (3)

Transuranium Waste (TRU) $>100 \mathrm{nCi} / \mathrm{g}$

TRU Processing (4)

TRU Mixed With RCRA Hazardous Cher rica

TRUMW Processing (5)

Waste (TRUMW)

LWW Mixed With RCRA Hazardous Chenical Waste (LMW)

RCRA Hazardous Chemical Waste LLWW Processing (6)

\section{Package And Send To DOE Or Off-Site}

RCRA Treatment, Storage, And/Or Disposal Facitty (TSDF)

Fig. 11(a). Waste generated during LA MOX fuel fabrication facility operation. 


\section{LLLW Processing}

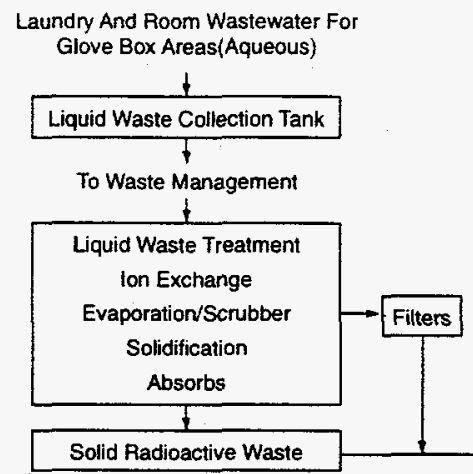

3. LLW Processing

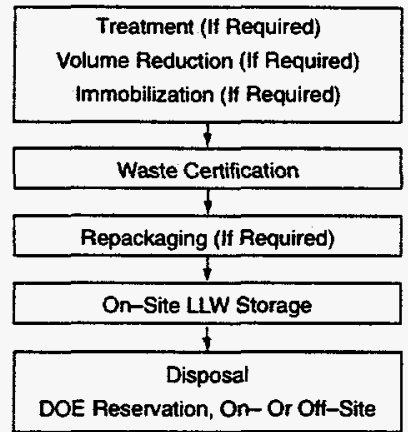

2. Solid Radioactive Waste

Glove Box And Some Room Waste

\begin{tabular}{|c|c|}
\hline Segregation By Generator & Hazardous Mixed Waste \\
\hline Compactable & 1 \\
\hline Noncompactable & Collection By Generator \\
\hline Special Case Waste & $I$ \\
\hline$T$ & Packaging By Generator \\
\hline Collection By Generator & 1 \\
\hline t & Certification By Generator \\
\hline Packaging By Generator & $I$ \\
\hline 1 & RCRA 90-d Storage \\
\hline Certification By Generator & \\
\hline To Waste Management & To Waste Management \\
\hline $\begin{array}{c}\text { Nondestructive Assay } \\
<100 \mathrm{nCi} / \mathrm{g} \text { To LLW Processing } \\
>100 \mathrm{nCi} g \text { To TRU Processing }\end{array}$ & $\begin{array}{c}\text { Nondestructive Assay } \\
<100 \mathrm{nCi} / \mathrm{g} \text { To LMW Processing } \\
>100 \mathrm{nCi} / \mathrm{g} \text { To TRUMW Processing }\end{array}$ \\
\hline
\end{tabular}

\section{LLMW Processing}

4. TRU Solid Waste >100 ncirg Processing

\section{TRUMW Processing}

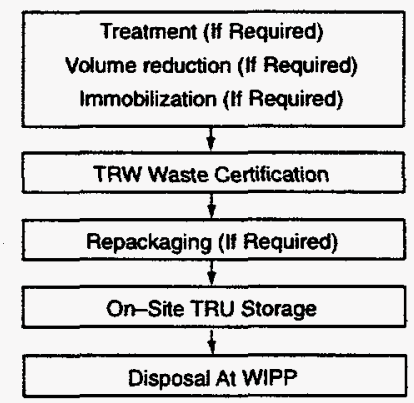

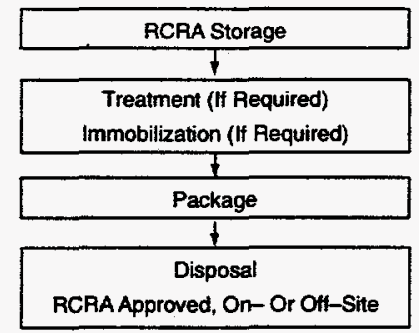

Fig. 11(b). Waste generated during LA MOX fuel fabrication facility operation. 
Patge Intentionally Blank 


\section{RESOURCE NEEDS}

\subsection{CONSTRUCTION RESOURCE NEEDS}

The modifications necessary for implementation of the LA fabrication effort have been described in detail in Sect. 2. All of the needed modifications involve the existing glove box line and related equipment. No modifications are expected to facilities or structures. Therefore, no significant construction resource requirements are expected. The only resource requirement that would increase over routine operations would be manpower needed to perform the modifications. The tasks that require the most manpower are modifications to the actual glove box line, including

- installation of blender and mill,

- D\&D of two contaminated glove boxes,

- installation of sintering furnace,

- removal of one uncontaminated glove box,

- installation of one new glove box, and

- installation of rod loading and welding equipment in clean glove box.

Based on data obtained from operational experience in PF-4, the person-hours required to complete these tasks were estimated by type of craft support and are shown in Table 7 along with the number of involved workers by craft.

This estimate assumes that non-glove box modifications (i.e., installation of storage racks) would require no unusual or significant resources.

Table 7. Manpower required for glove box line modifications

\begin{tabular}{lcc}
\hline Craft type & $\begin{array}{c}\text { Manpower required } \\
\text { (person-hours) }\end{array}$ & $\begin{array}{c}\text { Number of involved } \\
\text { workers }\end{array}$ \\
\hline Pipefitters & 2000 & 5 \\
Electricians & 1000 & 3 \\
Sheet-metal workers & 1500 & 5 \\
Radiological control technicians & 250 & 2 \\
\hline
\end{tabular}

\subsection{OPERATIONAL RESOURCE NEEDS}

The initial scaling factor for resource requirements for the LA fabrication facility is based on a linear measure derived from the capacity of the MOX fuel fabrication facility. The annual quantity of surplus plutonium [3.5 metric tons (MT) plutonium (4.0 $\left.\mathrm{MT} \mathrm{PuO}_{2}\right)$ ] and the MOX fuel fabrication facility requirements were obtained from the LANL Response to the Surplus Plutonium Disposition Environmental Impact Statement Data Call for a Mixed Oxide Fuel Fabrication Facility Located at the Pantex Plant. 10 The annual quantity requirement for uranium [88 MT HM (100 MT UO 2$)$ ] was obtained from the Initial Data Report and Response to the Surplus Plutonium Disposition Environmental Impact Statement Data Call for the $\mathrm{UO}_{2}$ Supply. 11 follows:

The annual plutonium and uranium capacity requirements and the scaling factors are calculated as

1. LA fabrication facility plutonium capacity

Plutonium required for production $=250 \mathrm{~kg} \mathrm{HM}$ plutonium

Plutonium required including rejection rate of $20 \%=250 \mathrm{~kg} \mathrm{HM}$ plutonium $\times 120 \%=300 \mathrm{~kg} \mathrm{HM}$ plutonium ( $50 \mathrm{~kg} \mathrm{HM}$ to be recycled)

Annualized plutonium requirements $=(300 \mathrm{~kg} \mathrm{HM}$ plutonium $) / 3$ years $=100 \mathrm{~kg} \mathrm{HM}$ plutonium Annualized MT HM plutonium capacity $=(100 \mathrm{~kg} \mathrm{HM}$ plutonium $) /(1000 \mathrm{~kg} / \mathrm{MT})=0.1 \mathrm{MT} \mathrm{HM}$ plutonium 
2. LA fabrication facility uranium capacity

Uranium required for production $=5000 \mathrm{~kg} \mathrm{HM}$ uranium

Uranium required including rejection rate of $20 \%=5000 \mathrm{~kg} \mathrm{HM}$ uranium $\times 120 \%=6000 \mathrm{~kg} \mathrm{HM}$ uranium (1000 $\mathrm{kg} \mathrm{HM}$ to be recycled)

Annualized uranium requirements $:=(6000 \mathrm{~kg} \mathrm{HM}$ uranium $) / 3$ years $=2000 \mathrm{~kg} \mathrm{HM}$ uranium

Annualized MT HM uranium capacity $=(2000 \mathrm{~kg} \mathrm{HM}$ uranium $) /(1000 \mathrm{~kg} / \mathrm{MT})=2.0 \mathrm{MT}$ HM uranium

3. LA fabrication facility capacity

Annual LA capacity $=(0.1$ plutonium +2.0 uranium $)$ MT HM $=2.1$ MT HM MOX

Annual mission surplus plutonium - 3.5 MT HM plutonium

Annual uranium requirements for mission $\mathrm{MOX}$ at $5 \%$ plutonium $=66.5 \mathrm{MT} \mathrm{HM}$ uranium

Annual MOX production $=(3.5$ plutonium +66.5 uranium $)$ MT HM MOX $=70$ MT HM MOX

4. Scaling factor $=(2.1 / 70) \mathrm{MT} H \mathrm{MMOX}=0.03 \%=3 \%$

This report assumes that $3 \%$ of the MOX fuel fabrication facility requirements is the initial base requirement of the LA fabrication facil ty. Resource requirements and contingencies in addition to $3 \%$ are noted separately for each resource. In situations where requirement scaling is not applicable, full calculations of resource requirements are provided. Resources needed for the LA fabrication facility are summarized in Table 8. (In the event LEU rods are used in place of some MOX rods, the resource needs will be reduced proportionately.)

\subsubsection{Utilities}

Utility connections at the sites being considered for the LA fabrication facility are currently installed and in use. For analysis purposes, it is not anticipated that additional connections will be required. Utility requirements beyond those necessary for maintenance of the building's present usage are based on those for the MOX fuel fabrication facility, scaled to $3 \%$, and then increased by a $200 \%$ contingency factor for bounding purposes. The original MOX requirements were developed from the NRC environmental report for the Westinghouse Recycle Fuels Plant (see Ref. 10, Appendix A) with a 200-MT MOX fabrication capacity. The annual requirements are calculated as

$$
24,000 \mathrm{MWh} \times(100 \mathrm{MT} / 200 \mathrm{MT}) \times 3 \% \times 200 \%=720 \mathrm{MWh} .
$$

The peak demand is based the MOX fabrication facility's peak demand of $<5 \mathrm{MW}(\mathrm{e})$ and is calculated as

$$
<5 \mathrm{MW}(\mathrm{e}) \times 1000 \mathrm{~kW}(\mathrm{e}) / \mathrm{MW}(\mathrm{e}) \times 3 \% \times 200 \%<300 \mathrm{~kW}(\mathrm{e}) .
$$

\subsubsection{Fuel Resources}

Fuel resource requirements for the LA fabrication facility are site dependent. Based on the MOX fabrication facility's generic fuel needs, it is assumed that the LA fabrication facility will require natural gas or coal for heating and electricity for sintering. Oil products or gasoline will be necessary for operation of two small generators and a small fleet of motorized vehicles.

Natural gas requirements for heating are calculated as

$$
920,000 \mathrm{~m}^{3} / \text { year } \times 3 \% \times 200 \% \text { contingency }=55,200 \mathrm{~m}^{3} / \text { year } .
$$

LANL will use natural gas for heating. 
Table 8. Resource needs during operation of the LA fabrication facility

\begin{tabular}{|c|c|}
\hline Resource requirement & Annual average consumption \\
\hline \multicolumn{2}{|l|}{ Utilities } \\
\hline Electricity & $720 \mathrm{MWh}$ \\
\hline Peak demand & $<300 \mathrm{~kW}(\mathrm{e})$ \\
\hline \multicolumn{2}{|l|}{ Fuel } \\
\hline Natural gas (for heating) & $55,200 \mathrm{~m}^{3}$ \\
\hline Diesel fuel (for generator) & $4,600 \mathrm{~L}(1,200 \mathrm{gal})$ \\
\hline Gasoline (for vehicles) & $6,900 \mathrm{~L}(1,825 \mathrm{gal})$ \\
\hline \multicolumn{2}{|l|}{ Water } \\
\hline Groundwater & $1,600,000 \mathrm{~L}(411,000 \mathrm{gal})$ \\
\hline Peak demand & No peak requirements anticipated \\
\hline Surface water & None required for this process \\
\hline \multicolumn{2}{|l|}{ Process chemicals and compounds $a$} \\
\hline \multicolumn{2}{|l|}{ Gases } \\
\hline Argon & $16,000 \mathrm{~m}^{3}\left(565,000 \mathrm{ft}^{3}\right)$ \\
\hline Helium & $10 \mathrm{~m}^{3}\left(350 \mathrm{ft}^{3}\right)$ \\
\hline Hydrogen & $1,000 \mathrm{~m}^{3}\left(35,500 \mathrm{ft}^{3}\right)$ \\
\hline Nitrogen & $5,300 \mathrm{~m}^{3}\left(187,000 \mathrm{ft}^{3}\right)$ \\
\hline Oxygen & $5,000 \mathrm{~m}^{3}\left(174,000 \mathrm{ft}^{3}\right)$ \\
\hline \multicolumn{2}{|l|}{ Liquids } \\
\hline Hydrochloric acid $(\mathrm{HCl})$ & $0.5 \mathrm{~kg}(1 \mathrm{lb})$ \\
\hline Nitric acid $\left(\mathrm{HNO}_{3}\right)$ & $1 \mathrm{~kg}(2 \mathrm{lb})$ \\
\hline Polyethylene glycol & $20 \mathrm{~kg}(<45 \mathrm{lb})$ \\
\hline Sulfuric acid $\left(\mathrm{H}_{2} \mathrm{SO}_{4}\right)$ & $2 \mathrm{~kg}(5 \mathrm{lb})$ \\
\hline \multicolumn{2}{|l|}{ Solids, kg (lb) } \\
\hline Sodium hydroxide $(\mathrm{NaOH})$ & $16 \mathrm{~kg}(34 \mathrm{lb})$ \\
\hline Sodium nitrate $\left(\mathrm{NaNO}_{3}\right)$ & $85 \mathrm{~kg}(<200 \mathrm{lb})$ \\
\hline Zinc stearate & $20 \mathrm{~kg}(<45 \mathrm{lb})$ \\
\hline \multicolumn{2}{|l|}{ Nonprocess chemicals } \\
\hline \multicolumn{2}{|l|}{ Liquids } \\
\hline Alcohol & $225 \mathrm{~L}(60 \mathrm{gal})$ \\
\hline Hydraulic fluid & $4.5 \mathrm{~kg}(10 \mathrm{lb})$ \\
\hline General cleaning fluids & $225 \mathrm{~L}(60 \mathrm{gal})$ \\
\hline \multicolumn{2}{|l|}{ Radioactive process materials } \\
\hline \multicolumn{2}{|l|}{ Plutonium dioxide $\left(\mathrm{PuO}_{2}\right)$} \\
\hline Hot startup & $23.6 \mathrm{~kg}(52 \mathrm{lb})$ \\
\hline Annually for 3 years & $113.5 \mathrm{~kg}(250 \mathrm{lb})$ \\
\hline \multicolumn{2}{|l|}{ Uranium dioxide $\left(\mathrm{UO}_{2}\right)$} \\
\hline Cold startup & $510 \mathrm{~kg}(1,125 \mathrm{lb})$ \\
\hline Hot startup & $475 \mathrm{~kg}(1,045 \mathrm{lb})$ \\
\hline Annually for 3 years & $2,270 \mathrm{~kg}(5,000 \mathrm{lb})$ \\
\hline
\end{tabular}

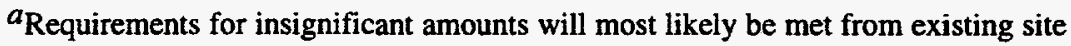
inventory. 
Oil products in the form of diesel fuel are required for operation of emergency generators. Based on technical specifications and testing requirements for generator operability, 12 each of two generators will operate $30 \mathrm{~h}$ yyear. Testing is required for $1 \mathrm{~h}$ each month for verification of operation, $1 \mathrm{~h}$ twice a year for full-load and manual synchronization: and $24 \mathrm{~h}$ every 18 months to confirm capability for continuous operation. Assuming that peak capacity is $300 \mathrm{~kW}(\mathrm{e})$ and that approximately $50 \%$ of peak demand should be available for glove box ventilation, emergency lighting, and other required electrical support, two $150-\mathrm{kW}$ capacity generators will be neisessary at the LA fabrication facility. Based on a consumption rate of $38 \mathrm{~L} / \mathrm{h}(10 \mathrm{gal} / \mathrm{h})$, requirements for oil products are calculated as follows:

$38 \mathrm{~L} / \mathrm{h} \times 30 \mathrm{~h} /$ year $\times 2$ generators $\times 200 \%$ contingency $=4560 \mathrm{~L} / \mathrm{year} \cong 4600 \mathrm{~L} / \mathrm{year}$.

Because of the facility size and the potential distances between areas being used to support the LA mission, a distance of up to 2.5 mile. $(4 \mathrm{~km})$ between the LA fabrication facility and other areas is assumed. An estimate of gasoline required for operation of motorized vehicle usage is based on requirements of 5 miles round-trip for 10 trips daily at $\sim 0.38 \mathrm{~L} / \mathrm{mile}(0.1 \mathrm{gal} / \mathrm{mile})$. The standard days of operation are calculated in Sect. 5.1 as $365 \mathrm{~d} /$ year. The fuel consumption for motorized vehicles at the LA fabrication facility is estimated as

$$
10 \text { trips } / \mathrm{d} \times 5 \text { miles } / \text { trip } \times 0.38 \mathrm{~L} / \text { mile } \times 365 \mathrm{~d} / \text { year }=6935 \mathrm{~L} / \text { year } \cong 6900 \mathrm{~L} / \text { year } .
$$

The total requirement for oil products is $\sim 11,500 \mathrm{~L} /$ year $(3,040 \mathrm{gal} / \mathrm{year})$.

\subsubsection{Water}

Based on the MOX fuel fabrication facility's water requirement of $25 \mathrm{gal} / \mathrm{d}(95 \mathrm{~L} / \mathrm{d})$ per employee, 24 employees working $250 \mathrm{~d}$ at the LA fabrication facility on the first shift, and 12 employees performing shift work for $365 \mathrm{~d}$, the annual sanitary water resource usage is calculated as

$(25 \mathrm{gal} / \mathrm{d}) \times[(24$ employees $\times 250 \mathrm{~d} /$ year $)+(12$ employees $\times 365 \mathrm{~d} /$ year $\times 2 \mathrm{shifts})$

$$
+(12 \text { employees } \times 115 \mathrm{~d} / \text { year })]=403,500 \mathrm{gal} / \mathrm{year},
$$

where calculations of the number of employees are in Sect. 5.1.

Nonsanitary water requirements are based on scaling the MOX fuel fabrication facility 10 with a $100-$ MT capacity to $10 \%$ of requirements. The $10 \%$ factor was used in lieu of $3 \%$ based on the nonlinear requirements for staffing between the MOX fuel fabrication facility and the LA fabrication facility. The usage is calculated as follows:

$$
191 \mathrm{gal} / \mathrm{d} \times 10 \% \times(365 \mathrm{~d} / \text { year })=6972 \text { gal/year } .
$$

Total groundwater usage is rounded to $411,000 \mathrm{gal} /$ year $(1,600,000 \mathrm{~L} / \mathrm{year})$.

\subsubsection{Process and Nonprocess Chemicals and Compounds}

Process and nonprocess chemicals in gas, liquid, and solid form will be required in the operation of the LA fabrication facility. Those chemicals required in significant quantities are identified in Table 8. Most of the chemicals required will be available from existing site inventory. 
It is assumed that the sintering furnace will have a purge rate of $30 \mathrm{~L} / \mathrm{min}$, requiring $\sim 94 \%$ argon and $6 \%$ hydrogen for operations. This number is derived as a function of the purge rates for large production furnaces that are typically on the order of $10 \mathrm{ft}^{3} / \mathrm{min}$. Assuming that the sintering furnace for the LA program will require one-tenth of the typical purge rate, a rate of $1 \mathrm{ft}^{3} / \mathrm{min}$ would be reasonable. There are $28.3 \mathrm{~L} / \mathrm{ft}^{3}$, which rounds up to $30 \mathrm{~L} / \mathrm{ft}^{3}$, resulting in a $30-\mathrm{L} / \mathrm{min}$ purge rate.

Because of requirement calculations for some chemicals resulting in minimal quantities, the amounts required have been rounded upward for bounding purposes. The quantities of process and nonprocess chemicals required in quantifiable amounts were calculated based on projected uses and requirements that follow.

Alcohol: for process and nonprocess cleaning purposes

$5 \mathrm{gal} / \mathrm{month} \times 12 \mathrm{months} / \mathrm{year}=60 \mathrm{gal} / \mathrm{year}$

Argon: required for sintering furnaces

$(30 \mathrm{~L} / \mathrm{min}) \times(525,600 \mathrm{~min} /$ year $) \times 0.001 \mathrm{~m}^{3} / \mathrm{L}=15,768 \mathrm{~m}^{3} /$ year $\cong 16,000 \mathrm{~m}^{3} /$ year

General cleaning fluids: for nonprocess cleaning purposes

$5 \mathrm{gal} /$ month $\times 12$ months $/$ year $=60 \mathrm{gal} /$ year

Helium: required as process gas

$0.2 \mathrm{~m}^{3} /$ week $\times 52$ weeks $/$ year $=10 \mathrm{~m}^{3} /$ year

Hydraulic fluid: lubricant

$0.2 \mathrm{lb} /$ week $\times 52$ weeks/year $\cong 10 \mathrm{lb} /$ year

Hydrochloric acid: required in service laboratory

$5 \mathrm{lb} \times 20 \%=1 \mathrm{lb} /$ year

Hydrogen: required in sintering furnaces

$(30 \mathrm{~L} / \mathrm{min}) \times(525,600 \mathrm{~min} /$ year $) \times 0.001 \mathrm{~m}^{3} / \mathrm{L} \times 6 \%=946 \mathrm{~m}^{3} / \mathrm{year} \cong 1000 \mathrm{~m}^{3} /$ year

Nitric acid: required in service laboratory

$8 \mathrm{lb} \times 20 \%=1.6 \mathrm{lb} /$ year $\cong 2 \mathrm{lb} /$ year

Nitrogen: required in glove boxes

$(1 \mathrm{~L} / \mathrm{min}) \times(525,600 \mathrm{~min} /$ year $) \times 0.001 \mathrm{~m}^{3} / \mathrm{L} \times 10$ glove boxes $=5256 \mathrm{~m}^{3} /$ year $\cong 5300 \mathrm{~m}^{3} /$ year

Oxygen: required for dry recycle process-assume $580 \mathrm{~h} /$ year dry recycle processing

$\left(5 \mathrm{ft}^{3} \mathrm{O}_{2} / \mathrm{min}\right) \times(60 \mathrm{~min} / \mathrm{h}) \times(680 \mathrm{~h} /$ year $)=\left(174,000 \mathrm{ft}^{3} \mathrm{O}_{2} /\right.$ year $) \cong 4927 \mathrm{~m}^{3} \cong 5000 \mathrm{~m}^{3} \mathrm{O}_{2} /$ year

Polyethylene glycol: required in blending process

$700 \mathrm{lb} \times 3 \% \times 200 \%=44 \mathrm{lb} /$ year $\cong 45 \mathrm{lb} /$ year

Sodium hydroxide: required in laboratory scrubber

$170 \mathrm{lb} \times 20 \%=34 \mathrm{lb} /$ year

Sodium nitrate: required in laboratory scrubber

$3100 \mathrm{lb} \times 3 \% \times 200 \% \cong 186 \mathrm{lb} /$ year $\cong 200 \mathrm{lb} /$ year

Sulfuric acid: required in service laboratory

$17 \mathrm{lb} \times 20 \%=3.4 \mathrm{lb} /$ year $\cong 5 \mathrm{lb} /$ year

Zinc stearate: required in pellet pressing process

$670 \mathrm{lb} \times 3 \% \times 200 \%=40.2 \mathrm{lb} /$ year $\equiv 45 \mathrm{lb} /$ year 


\subsubsection{Radioactive Process Materials}

The radioactive process materials used at the $\mathrm{LA}$ fabrication facility are $\mathrm{PuO}_{2}$ and $\mathrm{UO}_{2}$. Based on the bounding case of $100 \mathrm{~g}$ plutonium per rod, 264 rods per assembly (full MOX), 5\% plutonium for rods, and 10 full-MOX assemblies produced over a 3-year period, $113.5 \mathrm{~kg}(250 \mathrm{lb})$ of $\mathrm{PuO}_{2}$ and $2270 \mathrm{~kg}(5000 \mathrm{lb})$ $\mathrm{UO}_{2}$ would be required annually. The calculations are provided in Sects. 4.2.5.1 and 4.2.5.2.

\subsubsection{Plutonium requirements}

The conversion factor for plutonium to $\mathrm{PuO}_{2}=\left(\mathrm{mol} \mathrm{wt} \mathrm{PuO}_{2}\right) /(\mathrm{mol}$ wt plutonium $)=271.0 /$ $239.0=1.1339$.

$$
\begin{aligned}
& \text { Plutonium required for 3-year LA mission }=250 \mathrm{~kg} \mathrm{HM} \text { plutonium }(\text { Table } 5) \\
& \begin{aligned}
\text { Annual plutonium with rejection rate of } 20 \% & =250 \mathrm{~kg} \mathrm{HM} \text { plutonium } \times 120 \% / 3 \text { years } \\
& =100 \mathrm{~kg} \mathrm{HM} \text { plutonium } / \text { year }
\end{aligned} \\
& \begin{aligned}
100 \mathrm{~kg} \mathrm{HM} \text { plutonium } \times 1.1339=113.39 \mathrm{~kg} \mathrm{PuO}_{2} \equiv 113.5 \mathrm{~kg} \mathrm{PuO} 2 / \text { year }
\end{aligned}
\end{aligned}
$$

The plutonium requirements for hot startup operations are

$$
(250 \mathrm{~kg} \mathrm{HM} \text { plutonium }) /(3 \text { years }) \times 25 \% \times 1.1339=23.6 \mathrm{~kg} \mathrm{PuO} 2
$$

Total plutonium requirements for the $\mathrm{LA}$ fabrication facility for the 3-year mission are $364 \mathrm{~kg} \mathrm{PuO}_{2}$.

\subsubsection{Uranium requirements}

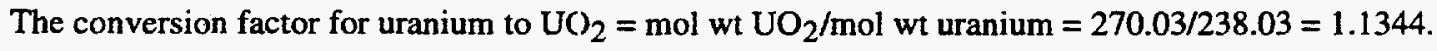

Uranium required for 3-year LA mission $=5000 \mathrm{~kg} \mathrm{HM}$ uranium (Table 5)

Annual uranium with rejection rate of $20 \%=5000 \mathrm{~kg} \mathrm{HM}$ uranium $\times 120 \% / 3$ years

$$
=2000 \mathrm{~kg} \mathrm{HM} \text { uranium } / \text { year }
$$

$2000 \mathrm{~kg} \mathrm{HM}$ uranium $\times 1.1544=2268.8 \mathrm{~kg} \mathrm{UO} 2 \cong 2270 \mathrm{~kg} \mathrm{UO} 2 /$ year

The uranium requirements for cold and hot startup operations during the first year of production follow.

Hot: (5000 kg HM uranium)/(3 years) $\times 25 \% \times 1.1344=472.67 \mathrm{~kg} \mathrm{UO} \cong 475 \mathrm{~kg} \mathrm{UO}$

Cold: $(5000 \mathrm{~kg} \mathrm{HM}$ uranium $) /(3$ years $) \times 27 \% \times 1.1344=510.49 \mathrm{~kg} \mathrm{UO}=510 \mathrm{~kg} \mathrm{UO}$

Total uranium requirements for the LA fabrication facility for the 3-year mission are slightly less than $7,800 \mathrm{~kg}(17,200 \mathrm{lb}) \mathrm{UO}_{2}$. 


\section{EMPLOYMENT REQUIREMENTS}

\subsection{ANNUAL EMPLOYMENT REQUIREMENTS DURING OPERATION OF THE LA FABRICATION FACILITY}

Table 9 provides the annual number of employees by labor category, the number of shifts, the number of employees per shift, and the number of operating days per year for the LA fabrication facility. It is assumed that the facility will operate continuously with the primary work effort during standard business days of operation at the selected site. The standard days of operation were calculated as follows:

$$
(365 \mathrm{~d} / \text { year })-[(104 \text { weekend days })+(11 \text { holidays })]=250 \mathrm{~d} / \text { year } .
$$

The 11 holidays considered are New Year's Day, Martin Luther King Day, Good Friday, Memorial Day, Independence Day ( 2 days), Labor Day, Thanksgiving ( 2 days), and Christmas ( 2 days).

The number of employees in Table 9 was derived from a reduction in personnel required for the MOX fuel fabrication facility with consideration given for the nature of operations necessary to maintain 24-h performance. ${ }^{10}$ Twenty-four employees will be required on the standard operation shift. Twelve additional employees will be required on each of two alternate shifts, resulting in total staffing needs of 60 employees.

Many of these positions probably will be filled by existing employees at the site. This estimate is generic in nature, and some of the sites under consideration may require fewer employees based on existing infrastructure. For example, facilities with on-site plutonium processing facilities may require only a nominal increase in support personnel and management. Industrial support organizations (such as site superintendent, site security, emergency response, health services, and personnel support) and atmospheric and groundwater monitoring will be provided by the site operator because these facilities are currently being serviced by the site.

Based on the estimates for the MOX fuel fabrication facility, a personnel requirement was established if more than $80 \%$ effort of a full-time equivalent (FTE) was charged out to support the LA fabrication facility operation. ${ }^{10}$ Those efforts requiring less than $80 \%$ of an FTE were considered part of operations of the existing site. The assumptions used in consideration of staffing levels for the LA fabrication facility are given in Table 10.

\subsection{RADIATION DOSES (WHOLE BODY) TO INVOLVED WORKERS DURING MODIFICATION OF THE LA FABRICATION FACILITY}

The level of manpower needed to complete the necessary modifications for the LA fabrication effort was detailed in Sect. 4. Using this information, the total number of involved workers for this effort is estimated as 15 (Table 11).

Based on data from PF-4 operational experience, the following assumptions were made as to the expected dose to workers involved in performing activities similar to those detailed in Table 7:

- $50 \%$ of manpower effort is needed for contaminated work (removal of contaminated glove boxes and replacement of equipment in glove box line);

- such contaminated work yields a conservative dose of $2 \mathrm{mrem} / \mathrm{h}$ to any one worker;

- $50 \%$ of manpower effort is needed for clean work (installation and removal of clean glove boxes, other activities not involving glove box line);

- such clean work yields a conservative dose of $0.5 \mathrm{mrem} / \mathrm{h}$ to any one worker; and

- Radiological Control Technicians (RCTs) receive a dose of only $0.5 \mathrm{mrem} / \mathrm{h}$ for both contaminated and clean work. 
Table 9. Annual imployment requirements during operation of the LA fabrication facility

\begin{tabular}{lcc}
\hline Labor category ${ }^{a}$ & $\begin{array}{c}\text { Number of } \\
\text { employees on one } \\
\text { shift of 250 d/year }\end{array}$ & $\begin{array}{c}\text { Number of employees on } \\
\text { each of three alternate shifts } \\
\text { of } 365 \mathrm{~d} / \text { year }\end{array}$ \\
\hline Officials and managers & 1 & 0 \\
Professionals & 4 & 0 \\
Technicians & 10 & 7 \\
Office and clerical & 2 & 0 \\
Craft workers (skilled) & 2 & 1 \\
Operatives (semiskilled) & 2 & 2 \\
Service workers & $\frac{3}{12}$ \\
$\quad$ Total & 24 & $\underline{12}$ \\
\hline
\end{tabular}

${ }^{a}$ All fractional manpower requirements are rounded up to whole numbers.

$b^{b}$ Two $365 \mathrm{~d} /$ year shifts and one $115 \mathrm{~d} /$ year shift.

Table 10. Assumptions used in consideration of staffing levels for the LA fabrication facility

1. The facility will be built on an existing DOE site with an estimate of $4500 \mathrm{ft}^{2}$ available space (3000 $\mathrm{ft}^{2}$ for MOX rod processing, $1000 \mathrm{ft}^{2}$ for bundling activities, and $500 \mathrm{ft}^{2}$ for fuel bundle storage).

2. The site will have an existing infrastructure in place to accept the LA mission.

3. Personnel will be required to support a process capacity of $\sim 2$ MT HM per year.

4. Personnel involved in SNM operations must work in pairs and follow specific safety precautions detailed by the site.

5. Personnel must attend required site training. A staffing requirement for training purposes has been included in this estimate.

6. Space will be allocated for safe secure transports (SSTs) carrying plutonium and transportation for uranium so that loading can be accomplished on a follow-up operating shift if the transport arrives near or following the close of standiard business.

7. As with the MOX fuel fabrication facility estimate, the staffing requirements assume that $-20 \%$ of the employee's time will be taken through training, vacation, personal leave, or illness. Even though employees cannot necessarily transition from one position to another, a contingency was added to account for nonproductive time.

Using the above assumptions and the manpower requirements for each craft provided in Sect. 4, the average dose to each involved worker can be estimated. The maximum dose to an involved worker, therefore, was estimated to be $500 \mathrm{mrem}$, as shown in Table 11. This maximum dose would be received by a pipefitter, because they require the highest number of person-hours for this effort. The average of the three crafts, and hence the average annual dose to an involved worker, is $383 \mathrm{mrem}$, as also shown in Table 11 .

\subsection{RADIATION DOSES (WHOLE HODY) TO INVOLVED WORKERS DURING OPERATION OF THE LA FABRICATION FACILITY}

The provided dose estimates to workers are based on those found in 10 Code of Federal Regulations (CFR) 835 and the administrative control level (ACL) found in DOE N 441.1. Fissile material processing for the LA program will be conducted at a DOE site and should be subject to DOE N 441.1, a DOE notice that establishes a maximum allowable dose of $2 \mathrm{rem} / \mathrm{year}$ (see Table 12). ALARA will be the goal in all 
operations. The primary hazard in the LA program will be processing $\mathrm{PuO}_{2}$ powder and the possibility of inhalation of the $\mathrm{PuO}_{2}$ dust.

Estimated dose to radiation workers for handling 3013 cans during $\mathrm{PuO}_{2}$ powder homogenization operations and blending with $\mathrm{UO}_{2}$ powder will be below the ACL found in DOE N 441.1.

Table 11. Radiation doses (whole body) to involved workers during modification of the $L A$ fabrication facility

Average annual dose to all involved workers at the facility, mrem

Maximum dose to an involved worker at the facility, mrem

500

Total number of involved workers

Table 12. Radiation doses (whole body) to involved workers during operation of the LA fabrication facility

Average maximum target annual dose to all involved workers at the

facility, mrem

Maximum allowable administrative dose limit, mrem 
Page Intentionally Blank 


\section{WASTES, EMISSIONS, AND EXPOSURES}

\subsection{WASTE GENERATED DURING FACILITY MODIFICATION}

A minor amount of waste is expected to be generated from the facility modifications for the LA fabrication effort. This waste will mainly be generated during the removal of glove boxes and the replacement of specified equipment in the glove box line. The waste produced from these modifications would be limited to nonregulated LLW and TRU wastes. No contaminants, such as lead, are expected, and hence it will not be considered RCRA, or regulated, waste.

The compatible LLW resulting from decontamination of a glove box includes such items as paper, rags, and gloves, and is disposed of in cardboard boxes. These boxes are $-0.30 \mathrm{~m}(1 \mathrm{ft})$ by $0.30 \mathrm{~m}(1 \mathrm{ft})$ by $0.61 \mathrm{~m}(2 \mathrm{ft})$, or $0.057 \mathrm{~m}^{3}\left(2 \mathrm{ft}^{3}\right)$ in volume, and on average weigh $7 \mathrm{~kg}(15 \mathrm{lb})$ when they contain LLW. Ninety of these boxes are packaged at a time to comprise a volume of $5.1 \mathrm{~m}^{3}\left(180 \mathrm{ft}^{3}\right)$ and are placed in a dumpster for shipping to a disposal area such as Area G in TA-54. Other low-level noncompactible waste (such as metal, glass, equipment, etc.) is placed in $2.5-\mathrm{m}^{3}\left(90-\mathrm{ft}^{3}\right)$ SEG boxes that on average weigh $-1015 \mathrm{~kg}(2240 \mathrm{lb})$ each. It is estimated that decontamination of one glove box generates about $2.5 \mathrm{~m}^{3}$ $\left(90 \mathrm{ft}^{3}\right)$ of waste. Thus, $5.0 \mathrm{~m}^{3}\left(180 \mathrm{ft}^{3}\right)$ of LLW would be generated during the removal of the two contaminated glove boxes.

The TRU waste generated during facility modifications would include the two contaminated glove boxes to be removed, the sintering furnace residing in the glove boxes identified for removal, and two blenders and two mills identified for replacement. The two glove boxes (currently in Room 126) are $2.4 \mathrm{~m}$ $(8 \mathrm{ft})$ long and $1.5 \mathrm{~m}(5 \mathrm{ft}$ ) wide; one is single height, and the other is double height. The average weight of a glove box is $3800 \mathrm{~kg}(8300 \mathrm{lb})$, and the average volume is $10 \mathrm{~m}^{3}\left(353 \mathrm{ft}^{3}\right)$. Because the glove boxes are considered to be oversized TRU waste, special packaging is required, so custom-designed plywood boxes are built for each glove box for shipment.

The two blenders are $~ 0.61 \mathrm{~m}$ ( $2 \mathrm{ft}$ ) wide, $0.30 \mathrm{~m}$ (1 ft) deep, $0.46 \mathrm{~m}$ (18 in.) high, and weigh $14 \mathrm{~kg}$ ( $30 \mathrm{lb}$ ) each. The mills are $\sim 0.38 \mathrm{~m}$ ( $15 \mathrm{in}$.) wide, $0.76 \mathrm{~m} \mathrm{(30} \mathrm{in.)} \mathrm{deep,} 0.30 \mathrm{~m}$ (1 ft) high, and weigh $27 \mathrm{~kg}$ $(60 \mathrm{lb})$ each. The sintering furnace is $0.38 \mathrm{~m}$ (15 in.) in diameter and is $0.46 \mathrm{~m} \mathrm{(18} \mathrm{in.)} \mathrm{tall.} \mathrm{All} \mathrm{this} \mathrm{TRU}$ waste will be wrapped in plastic and placed in $0.208-\mathrm{m}^{3}$ (55-gal) waste drums for disposal in TA-54 Area G. On average, these containers weigh $150 \mathrm{~kg}(330 \mathrm{lb})$ each.

The radionuclides that will be present in both the LLW and TRU waste consist mainly of ${ }^{239} \mathrm{Pu}$, ${ }^{235} \mathrm{U}$, and ${ }^{241} \mathrm{Am}$. No other contaminants are expected to be present. Modifications to previously contaminated land are not planned, and no new treatment, storage, or disposal facilities will be created as a result of modifications. Furthermore, no radioactive emissions are anticipated to be released from the facility as a result of the modifications.

\subsection{WASTES GENERATED DURING OPERATION OF THE FACILITY}

Table 13 provides the annual volume, total estimated volume, description, and anticipated treatment method by waste category for liquids and solids anticipated during operation of the LA fabrication facility. Only very small quantities of chemical emissions are anticipated from analytical operations resulting from sampling.

A total of $0.4 \mathrm{mg} / y e a r$ of plutonium is estimated to be released to the air during the operation of the LA MOX facility. This plutonium release corresponds to a total activity of $94 \mu \mathrm{Ci} /$ year. The total plutonium release includes two contributions; $0.3 \mathrm{mg} / y e a r$ is expected to be released during normal operation of the plant and an additional $0.1 \mathrm{mg}$ /year during a one-time abnormal event (spilling the powder of one 3013 can).

The release during normal operation has been estimated from the releases reported in Ref. 2 for a 100-MT HM/year MOX plant with two lines. Reference 2 reports a release of $0.6 \mathrm{mg} /$ year of plutonium. The LA MOX facility has only one line and a smaller capacity (about 2.5 MT HM/year). For conservatism, one-half of the releases of the large MOX plant (with two lines) has been estimated for the small LA MOX facility (with only one line); therefore, the value is $0.3 \mathrm{mg} / \mathrm{year}$. No scaling consideration has been given to the much smaller capacity of the LA MOX facility (about 1/40 of the large MOX plant). 
Table 13. Estimated waste generated during operation of the LA fabrication facility $a$

\begin{tabular}{|c|c|c|c|c|c|c|c|}
\hline \multirow{2}{*}{$\begin{array}{c}\text { Waste } \\
\text { category }\end{array}$} & \multicolumn{2}{|c|}{ Annual volume } & \multicolumn{2}{|c|}{ Total volume } & \multirow{2}{*}{$\begin{array}{c}\text { Waste } \\
\text { description }\end{array}$} & \multirow{2}{*}{$\begin{array}{l}\text { Anticipated } \\
\text { treatment }\end{array}$} & \multirow{2}{*}{$\begin{array}{l}\text { Disposal } \\
\text { method }\end{array}$} \\
\hline & $\left(m^{3}\right.$ or $\left.L\right)$ & $\left(\mathrm{ft}^{3}\right.$ or gal) & $\left(m^{3}\right.$ or $\left.L\right)$ & $\left(\mathrm{ft}^{3}\right.$ or gal) & & & \\
\hline TRU_-solid $\left(\mathrm{m}^{3}\right.$ or $\left.\mathrm{ft}^{3}\right)$ & 40 & 1,413 & 130 & 4,591 & $\begin{array}{l}\text { Glove box gloves } \\
\text { Bag-in plastic } \\
\text { Empty bottles } \\
\text { Filters } \\
\text { Scrapped equipment items } \\
\text { Furnace hardware } \\
\text { Wipes } \\
\text { Metal cans } \\
\text { Metallography waste }\end{array}$ & Compaction & $\begin{array}{l}\text { Orf-site at Waste Isolation Pilot } \\
\text { Plant (WIPP) }\end{array}$ \\
\hline TRU-mixed $\left(\mathrm{m}^{3} \text { or } \mathrm{ft}^{3}\right)^{b}$ & $<1$ & $<35$ & $<1$ & $<35$ & $\begin{array}{l}\text { Organics from sintering } \\
\text { Sludges from liquids } \\
\text { Analytical waste }\end{array}$ & $\begin{array}{l}\text { From liquid treatment } \\
\text { absorption to TRU solid }\end{array}$ & Off-site at WIPP \\
\hline TRU-liquids (L or gal) & 200 & 53 & 650 & 172 & $\begin{array}{l}\text { Sludges from liquids } \\
\text { Analytical waste } \\
\text { Metallography waste }\end{array}$ & $\begin{array}{l}\text { Absorption to TRU solid } \\
\text { or liquid LLW }\end{array}$ & As solid off-site at WIPP \\
\hline$L L W-$ solid $\left(\mathrm{m}^{3}\right.$ or $\left.\mathrm{ft}^{3}\right)$ & 40 & 1,413 & 140 & 4,944 & $\begin{array}{l}\text { Room trash } \\
\text { Blotter paper } \\
\text { Wipes } \\
\text { Mop heads } \\
\text { Gloves/shoe covers } \\
\text { Solidified sludges } \\
\text { lon exchange resins } \\
\text { Discarded C-clothing } \\
\text { Metal cans and rods }\end{array}$ & $\begin{array}{l}\text { Incineration } \\
\text { Compaction } \\
\text { Solidification } \\
\text { Metal melting }\end{array}$ & DOE on- or off-site disposal \\
\hline LLW-mixed (L or gal) & 1 & 0.3 & 4 & 1.1 & $\begin{array}{l}\text { Solvents from cleaning } \\
\text { Analytical waste } \\
\text { Sludges from liquids }\end{array}$ & $\begin{array}{l}\text { Incineration } \\
\text { Solidification }\end{array}$ & $\begin{array}{l}\text { RCRA-approved disposal } \\
\text { DOE on- or off-site } \\
\text { Commercial off-site }\end{array}$ \\
\hline LLW-liquid ( $L$ or gal) & 160,000 & 42,267 & 560,000 & 147,935 & $\begin{array}{l}\text { Decontaminated wastewater } \\
\text { Laundry wastewater } \\
\text { Analytical wastewater }\end{array}$ & $\begin{array}{l}\text { Ion exchangé } \\
\text { Evaporation/ } \\
\text { scrubber } \\
\text { Solidification }\end{array}$ & $\begin{array}{l}\text { Evaporation } \\
\text { NPDES }{ }^{c} \text { permitted discharge }\end{array}$ \\
\hline Hazardous (L or gal) & 1.5 & 0.4 & 4 & & Process ends & Recycle & \\
\hline Nonhazardous - liquid (L or gal) & $1,600,000$ & 411,000 & $6,400,000$ & $1,644,000$ & Sewage waste & Sewage treatment & NPDES permitted discharge \\
\hline
\end{tabular}

${ }^{a}$ Base numbers were generated in metric system to two significant figures; English units are conversions using factors provided in data call.

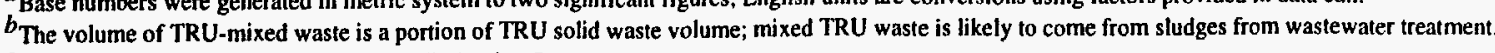

$c_{\text {NPDES }}=$ National Pollutant Discharge Elimination System.

Note: Estimates are based on historical experience from other prograns and current programs. 
The release during the abnormal event has been calculated by dropping one 3013 can containing $4.5 \mathrm{~kg}$ of plutonium. From Ref. 5 (Table 4-13) the following factors were selected:

- ARF (airborne release fraction) $=3.3 \times 10^{-3}$

- $\mathrm{RF}$ (respirable factor) $=0.62$

Also, the efficiency of the HEPA filters in the glove box has been assumed to be $99.9 \%$ (equivalent to a release factor of $10^{-3}$ ) and the efficiency of the building HEPA filters as $99 \%$ (equivalent to a release factor of $10^{-2}$ ). Overall, the air emission for this event is

$$
4500 \mathrm{~g} \times 3.3 \times 10^{-3} \times 0.62 \times 10^{-3} \times 10^{-2}=0.092 \mathrm{mg} / \text { year } \cong 0.1 \mathrm{mg} / \text { year } .
$$

Air emissions will result from the burning of natural gas for building heat, but no more than would be expected if this activity did not occupy buildings at the LANL site. 


\section{Page Intentionally Blank}




\section{ACCIDENT ANALYSIS}

\subsection{INTRODUCTION}

The LA fabrication process represents a very small scale process replication of the large 100-MT/year MOX fuel fabrication facility. The LA assembly fabrication will likely take place in an existing building complex. The process is envisioned to consist of a number (10-20) of glove boxes along with several hoppers, a press, a furnace, and a rod/bundle assembly area. The process can be done in a single large room, but it may also be done using several rooms (or buildings) with the material at the end stage of certain steps involving transportation and/or storage at another building. A generalized approach was taken because these specifics were unknown. Section 7.2 describes the accident analysis approach and mitigating design features that are assumed to be available. Section 7.3 describes the events that were selected for EIS evaluation and the estimated source terms that were chosen for all sites. These source terms are characterized here as "evaluation basis" because the facilities already exist and may have other design basis accidents that may or may not be similar to these accidents. Chemical source terms for the facility are discussed in Sect. 7.4. Site-specific aspects are discussed in Sect. 7.5.

\subsection{GENERAL APPROACH AND GENERIC DESIGN ASSUMPTIONS}

\subsubsection{Accident Analysis Approach}

In Ref. 12, a preliminary hazards analysis (PHA) was referenced for a 100-MT/year MOX fuel fabrication plant. This analysis identified 32 accidents which resulted from a variety of events. Specific events for the design-basis and beyond-design basis accidents were then selected from the hazard analysis to be further analyzed in the EIS. In that analysis, four design basis accidents and two beyond-design basis accidents were selected.

Several accident scenarios can be postulated for processing facilities, and many do not result in a source term that leaves the building. The objective of this accident analysis is to examine the frequency and estimated source terms of several events that are expected to result in a significant release from the building. Ventilation system design assumptions such as the use of HEPA filters that affect the leak-path factor are discussed in the next section. Using the methodology in Ref. 13, source terms are derived based on the combination of the material at risk, damage ratio, release fractions, respirable fractions, and the building leak-path factor.

The many unknowns and options associated with the LA fabrication plant did not warrant the performance of a building-/process-specific PHA for the LA facility. Currently, several different proposed fuel fabrication processes are combined with five sites. Knowledge concerning the PHA in Ref. 10 was combined with a knowledge of what the LA plant would generally be expected to look like. These aspects, along with a conservative estimate of the expected material flows of the plant, were used to select conservative accident source terms for the LA EIS analysis. Even though the scale of the LA plant is much smaller, it is thought that the LA facility will have many of the same accident initiators. Selected accident scenarios and the materials at risk were combined with bounding airborne release fractions and respirable fractions from DOE HDBK-3010-94 (Ref. 13) to derive conservative source terms.

With respect to estimated frequencies, the same approach that was taken in Ref. 10 is used. Frequency categories of anticipated $\left(10^{-1} /\right.$ year to $10^{-2}$ /year), unlikely $\left(10^{-2}\right.$ /year to $10^{-4} /$ year $)$, extremely unlikely $\left(10^{-4} /\right.$ year to $10^{-6} /$ year $)$, and beyond the evaluation basis $\left(<10^{-6}\right.$ /year for most events) were usually assigned in this assessment.

No attempt was made to quantify all of the site-specific features that affect the accident analysis. Rather, a generic set (six events are evaluated) of source term magnitudes was used at each site. This set of source terms was derived based on a specified plant process and some general assumptions regarding facility mitigators. No claim is made that the accident source terms cited here bound or are bounded by the existing site-specific analysis. Some site specifics such as stack heights and seismic frequencies were deemed to be a necessary input. The site-specific characteristics used for this site are discussed in Sect. 7.5. 
The generic facility design assumptions that are made which are not site-specific are discussed in Sect. 7.2.2.

\subsubsection{Facility Design Assumptions}

\subsubsection{Plutonium isotopics and MOX fuel}

The isotopic compositions of the plutonium and various MOX blends are shown in Table 14. With respect to both the master mix and fut: blend, the uranium dominates (a minimum of $90 \%$ ) the weight percent of the mix. However, the radiological contribution of the low specific activities of the uranium isotopes ( $\sim 5$ orders of magnitude) are so low (as compared to the plutonium isotopes) that they are ignored in the calculation of the source terms. In the event LEU rods are used in place of some MOX rods, the radiological contribution from the LEU rods will also be very low compared to the plutonium contribution. Therefore, the accident analyses only considered full MOX assemblies. The respective isotopic activities for the plutonium oxide powder and the MOX powder (conservatively assuming $10 \%$ enrichment) or fuel are shown in this table. For each accident sisenario, the appropriate $\left(\mathrm{PuO}_{2}\right.$, master mix, or fuel blend) isotopic ratios are applied to the quantities at risk to determine the material at risk. This number is then multiplied by the leak-path factor, damage ratio, sirborne release fraction, and respirable fraction to determine the released source terms. The leak-path factor incorporates the assumption as to whether the release is filtered.

\subsubsection{Ventilation system}

A complete description of site-specific existing facility ventilation system specifics is beyond the scope of this section. However, in many process buildings, ventilation flows are maintained such that fresh air is taken through the cleanest radiological areas (such as adjacent offices) first. The air flow path is then drawn through the rooms where radiological work is performed. Most facility systems are designed such that glove boxes in these rooms are run at pressures lower than the room pressure to limit the spread of contamination in the event of glove box failure. Contamination would be drawn in to the glove box filter to limit contamination in the room. The exact facility specifics and credit for mitigating design features involved in accident situations will vary, depending on the facility selected and any facility modifications needed to support the LA mission. The ir tent of this section is to clearly describe the mitigators associated with the ventilation system that are credited in this analysis.

Generally, a number of filters and prefilters would exist in the release path for a typical processing building that supports plutonium processing. Usually one or more filters are at the ventilation outlet of the glove box. These filters are generally accessible in the room where the glove box is located. However, no credit in source term reduction was taken for these filters in this analysis. This approach was taken because arguments could be made that the events in question jeopardize the integrity of nearby filters. For the EIS purposes, this approach was deemed appropriate. However, this does not mean that in the safety analysis (which would be performed after the building has been selected) of various glove box designs, credit could never be taken for those (or other) filters. The decision of what equipment will be qualified (and credit assumed for in the various events) will be made during the subsequent safety review of the facility (e.g., after facility selection). This decision is beyond the scope of this EIS analysis because many facility specific aspects are not known at this stage of the analysis.

The glove box system may be served by a dedicated ventilation system that often ties into the overall system upstream of a series of HEPA filters. With respect to the analysis of events in which overall building confinement is maintained, credit (for the source term reduction) is taken for two serial HEPA filters that generally lie outside the building confinement. The efficiency is assumed to be $99.9 \%$ for the first filter. A HEPA filter at the factory is rated at $99.97 \%$, but when installed may test to $99.95 \%$. The facility may run with this for a while and allow some degradation in performance during the operating period. Thus, in practice, a $99.9 \%$ efficiency is judged to be appropriate for this filter (roughing filters and prefilters are ignored). A reduced efficiency of $99.0 \%$ is used for the second filter (resulting in a combined leak-path factor of $1 \times 10^{-5}$ ). These filters are considered in this analysis where confinement is assumed to be intact and to provide significant source term reduction. 
Table 14. Specific activities for process powders (source of isotopics-Ref. 10)

\begin{tabular}{lrcccc}
\hline \multicolumn{5}{c}{ (source of isotopics-Ref. 10) } \\
\hline Isotope $^{a}$ & $\begin{array}{c}\text { Weight } \\
\text { percent }\end{array}$ & $\begin{array}{c}\text { Specific activity } \\
(\mathrm{Ci} / \mathrm{g})^{b}\end{array}$ & $\begin{array}{l}\text { Activity in } \\
\mathrm{PuO}_{2} \text { mix } \\
(\mathrm{Ci} / \mathrm{g} \mathrm{mix})^{c}\end{array}$ & $\begin{array}{c}\text { Activity in } 30 \% \mathrm{PuO}_{2} \\
\text { enriched } \mathrm{MOX} \text { mix } \\
(\mathrm{Ci} / \mathrm{g} \mathrm{mix})^{d}\end{array}$ & $\begin{array}{c}\text { Activity in } 10 \% \mathrm{PuO}_{2} \\
\text { enriched MOX mix } \\
(\mathrm{Ci} / \mathrm{g} \mathrm{mix})^{d}\end{array}$ \\
\hline${ }^{238} \mathrm{Pu}$ & 0.03 & $1.712 \times 10^{1}$ & $4.530 \times 10^{-3}$ & $1.359 \times 10^{-3}$ & $4.530 \times 10^{-4}$ \\
${ }^{239} \mathrm{Pu}$ & 92.44 & $6.204 \times 10^{-2}$ & $5.045 \times 10^{-2}$ & $1.514 \times 10^{-2}$ & $5.045 \times 10^{-3}$ \\
${ }^{240} \mathrm{Pu}$ & 6.47 & $2.270 \times 10^{-1}$ & $1.293 \times 10^{-2}$ & $3.879 \times 10^{-3}$ & $1.293 \times 10^{-3}$ \\
${ }^{241} \mathrm{Pu}$ & 0.05 & $1.030 \times 10^{2}$ & $4.542 \times 10^{-2}$ & $1.363 \times 10^{-2}$ & $4.542 \times 10^{-3}$ \\
${ }^{242 \mathrm{Pu}}$ & 0.10 & $3.926 \times 10^{-3}$ & $3.463 \times 10^{-6}$ & $1.039 \times 10^{-6}$ & $3.463 \times 10^{-7}$ \\
${ }^{241} \mathrm{Am}$ & 0.90 & $3.428 \times 10^{0}$ & $2.721 \times 10^{-3}$ & $8.163 \times 10^{-3}$ & $2.721 \times 10^{-3}$ \\
\hline
\end{tabular}

$a_{\text {The activity of }}{ }^{235} \mathrm{U}$ and ${ }^{238} \mathrm{U}$ are ignored for all mixes because of their low specific activities as compared tc the plutonium isotopes.

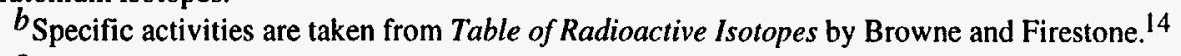

${ }^{c}$ Based on $\mathrm{PuO}_{2}$ mix being $88.2 \%$ plutonium by weight.

$d_{30 \%}$ is master mix; $10 \%$ is a conservative estimate for fuel blend. 


\subsubsection{Process flows}

Table 15 shows the process inventories and material flows used for the accident analysis. The average plutonium enrichment is nominally taken to be $5 \%$ for the fuel. However, because some fuel blends could go higher, an upper bound of $10 \%$ plutonium enrichment was selected. Table 15 was generally constructed on that basis. A $30 \%$ master mix blend was also selected. Table 15 was not intended to rigidly define the fuel fabrication material process because a number of candidate processes (with different material balances) may be used in the facility. Because the purpose of this table is to provide materials at risk, a conservative estimate of the maximum amount of ma erial at a process station or in interim storage at a certain location was made.

Table 15. Estimated maximum station inventories for LA fabrication plant ${ }^{a}$

\begin{tabular}{|c|c|c|c|c|}
\hline Location/material station & $\begin{array}{l}\text { Quantity' } \\
\text { (g) }\end{array}$ & $\mathrm{PuO}_{2}$ or $\mathrm{MOX}$ & Physical form & $\begin{array}{l}\text { Barriers to release } \\
\text { (to the room) }\end{array}$ \\
\hline Plutonium storage vault & 400,000 & $\mathrm{PuO}_{2}$ & Fine powder & Storage cans/vault \\
\hline $\begin{array}{l}\text { Plutonium oxide ( } 2 \text { cans in } \\
\text { process) }\end{array}$ & 10,000 & $\mathrm{PuO}_{2}$ & Fine powder & $3013 \operatorname{can}^{15}$ \\
\hline $\begin{array}{l}\text { Plutonium oxide loading } \\
\text { vessel }\end{array}$ & 16,000 & $\mathrm{PuO}_{2}$ & Fine powder & Steel vessel/glove box \\
\hline Master mix vessel & 53,000 & MOX (30\% blend) & Fine powder & Steel vessel/glove box \\
\hline Master mix powder storage & 107,000 & MOX (30\% blend) & Fine powder & $\begin{array}{l}\text { Interim storage } \\
\text { cans/glove box }\end{array}$ \\
\hline V-blender & 40,000 & MOX (10\% blend) & Fine powder & $\begin{array}{l}\text { Rotating steel } \\
\text { vessel/glove box }\end{array}$ \\
\hline MOX blend storage & 320,000 & MOX (10\% blend) & Fine powder & $\begin{array}{l}\text { Interim storage } \\
\text { cans/glove box }\end{array}$ \\
\hline MOX granulation area & 10,000 & MOX (10\% blend) & $\begin{array}{l}\text { Pressed/very } \\
\text { coarse powder }\end{array}$ & Machinery/glove box \\
\hline MOX pellet press & 1,000 & MOX (10\% blend) & $\begin{array}{l}\text { Pressed to } 0.6 \\
\text { theoretical } \\
\text { density (TD) }\end{array}$ & $\begin{array}{l}\text { Inside of press/glove } \\
\text { box }\end{array}$ \\
\hline $\begin{array}{l}\text { MOX green pellet storage (in } \\
\text { pellet press area) }\end{array}$ & 80,000 & MOX (10\% blend) & $\begin{array}{l}\text { Pressed to } 0.6 \\
\text { TD }\end{array}$ & $\begin{array}{l}\text { Interim storage } \\
\text { cans/glove box }\end{array}$ \\
\hline Pellet sintering furnace & 40,000 & MOX (10\% blend) & $\begin{array}{l}\text { Green and } \\
\text { sintered }\end{array}$ & $\begin{array}{l}\text { Inside furnace/glove } \\
\text { box }\end{array}$ \\
\hline Sintered pellet storage & 160,000 & MOX (10\% blend) & Sintered pellets & $\begin{array}{l}\text { Interim storage } \\
\text { cans/glove box }\end{array}$ \\
\hline $\begin{array}{l}\text { Pellet grinding area/ground } \\
\text { sintered pellets }\end{array}$ & 10,000 & MOX (10\% blend) & $\begin{array}{l}\text { Grindings of } \\
\text { sintered pellets }\end{array}$ & Containers/glove box \\
\hline $\begin{array}{l}\text { Pellet grinding area/dust } \\
\text { control area }\end{array}$ & 100 & MOX (10\% blend) & Fine powder & Loose dust/glove box \\
\hline Pellet inspection & 4,000 & MOX ( $10 \%$ blend) & Finished pellets & Trays/glove box \\
\hline $\begin{array}{l}\text { Fuel rod loading, inspection, } \\
\text { and storage }\end{array}$ & 20,000 & MOX (10\% blend) & Finished pellets & $\begin{array}{l}\text { About ten rods if } \\
\text { cladded }\end{array}$ \\
\hline $\begin{array}{l}\text { Bundle assembly and storage } \\
\text { (end of fabrication) }\end{array}$ & $7,200,000$ & $\begin{array}{l}\text { MOX (5\% average } \\
\text { blend) }\end{array}$ & Finished pellets & $\begin{array}{l}\text { Cladded in ten } \\
\text { bundles }\end{array}$ \\
\hline Scrap recovery area & 10,000 & $\mathrm{MOX}$ and $\mathrm{PuO}_{2}$ & $\begin{array}{l}\text { Mostly green and } \\
\text { sintered pellets }\end{array}$ & Few dispersibles \\
\hline
\end{tabular}

$a_{\text {No more than }} 32 \mathrm{~kg}$ of $\mathrm{PuO}_{2}$ (a batch) : $\mathrm{s}$ used in the process line.

Source: Ref. 15. 
It is important to remember that with respect to assumed process flows, no more than $32 \mathrm{~kg}$ of plutonium oxide is ever assumed to be in the process line between the plutonium oxide vessel and the fuel rod loading step. As a result, no more than $32 \mathrm{~kg}$ of plutonium oxide (which is about $28 \mathrm{~kg}$ of pure plutonium) would be at risk in the process line, except for events that involve the vault (which is involved in beyond-evaluation basis events). The $32 \mathrm{~kg}$ of oxide does not include the two cans containing $5 \mathrm{~kg}$ of pure plutonium oxide that are assumed to be in process between the vault and the oxide loading vessel. Thus, a total of $42 \mathrm{~kg}$ of oxide in powder form has been considered in this analysis. Finished fuel rods are not considered because they are generally nondispersible as compared to powder. No effort has been made to model site-specific process flows and distinguish corresponding risk differences because there are so many process and facility unknowns at present. Rather, a generic (but thought to be generally conservative) process flow assumption has been made for all sites. Site-specific differences considered in the analysis are discussed in Sect. 7.5.

For most, if not all accident scenarios, materials at risk will be subjected to orders of magnitude multipliers in the calculation to determine the released source term. Thus, a high level of accuracy is not warranted at this stage of the analysis. Table 15 was used in combination with Ref. 13 and knowledge of the accident dynamics to obtain the source terms for the LA fabrication facility. In each accident scenario, a material at risk assumption is made at each station, depending on the event and energetics. Table 15 also lists the barriers to release that would be found inside the glove box. Generally, those materials that are inside interim storage cans were considered to be the most vulnerable to dispersion.

It is assumed that large amounts of $\mathrm{PuO}_{2}$ powder would be safely stored in appropriate containers ${ }^{15}$ inside a vault or existing storage location. Considerable credit is taken for this vault (and/or the plutonium oxide containers), and it is assumed that the entire plutonium material feed requirement is in the vault at the start of the mission. It was conservatively assumed that $400 \mathrm{~kg}$ of oxide powder is in the vault at the start of the process. This inventory is held in 80 cans, each of which holds $5 \mathrm{~kg}$ of oxide powder $(4.4 \mathrm{~kg}$ of plutonium).

The overall layout of the facility is such that from 10-20 glove boxes are accommodated. The equipment is considered to be located in the same room, and generally, little credit is taken for segregation of the processes. Little credit is also taken for the glove boxes. The glove boxes are generally assumed to fail in the postulated events. This may or may not accurately portray the process line once it is designed (because glove boxes with a robust design may be used). However, this approach is thought to be conservative.

Finished fuel assemblies and clad rods were considered in this analysis but are thought to be generally nondispersible. Accidents that involve this inventory are thought to be bounded by the accidents involving the vault and the other in-process steps where dispersible powders are involved.

\subsection{SELECTED EVENTS FOR THE LA EIS ANALYSIS}

\subsubsection{Criticality Event}

\subsubsection{Discussion}

The prevention of criticality events is a major goal of the criticality safety program and is an important part of the overall conduct of operations for the facility. Within the nuclear processing industry, such prevention programs have successfully reduced the number of inadvertent criticalities over the years. The goal of the criticality safety program is to attempt (as much as is reasonably possible) to make the possibility of a criticality less than credible (generally accepted to be $<1 \times 10^{-6} /$ year frequency). Reference 16 establishes the DOE's nuclear criticality safety program requirements. Similarly, NRC also requires a criticality safety program, and those requirements are assumed to be implemented at the LA fabrication facility.

The risk impact associated with an inadvertent criticality event is highest with respect to workers located in the immediate vicinity (health impacts up to and including death could occur from prompt gamma and neutron doses). Collocated workers and the public would be affected to a lesser degree. The major dose pathways for these impacts are likely to be cloud shine (noble gases) and inhalation (mostly associated with the radioiodines). 
With respect to the LA fabrication plant, criticalities could be postulated in several areas (i.e., powder storage, the glove boxes involved in nixing, the furnace, and possibly the fuel rod storage area). The estimated frequencies associated with these events will vary depending on the controls in place, the number of operator movements, and the amount of fissile material present. A generic approach was taken with respect to the selection of the specifics of this event rather than selecting a criticality scenario associated with a specific operation in the LA fabrication.

\subsubsection{Source term}

The significant quantities of fissil: materials in LA necessitate consideration of a criticality event. Because a limited number of rods are being made, a criticality event associated with a large array of fuel rods was not selected for this event. Because sources of moderation may be assumed to be either accidentally or inadvertently introduced into the glove boxes/equipment, the limiting fission yield for the facility was based on a scenario for a mcderated powder or moderated solid criticality. In Ref. 17 (p. 6-24) dry powder and metal criticalities are quisted at a conservative yield of $1 \times 10^{17}$ fissions. A reference yield of $1 \times 10^{18}$ fissions is considered conservative for fully moderated and reflected solids. Therefore, a conservative selection of $1 \times 10^{18}$ fissions was made for the evaluation of this criticality event.

It is acknowledged that a dry crilicality could potentially aerosolize surrounding plutonium and generate respirable particles. The amount of aerosolization is expected to be very small, and the presence of multiple filters would be an effective nitigator against the spread of plutonium out of the ventilation system. Thus, no plutonium was assumed to constitute the source term with respect to exposure of the collocated workers and the public that are outside of the building. Other events involving significant plutonium releases are discussed later.

With respect to release fractions aisociated with the fission products, it would be expected that a powder would have a surface area such that all noncondensible gases (such as the nobles) and all radioiodines would escape. However, if the criticality involved plutonium, which was in a relatively low surface area to volume ratio, the release f:action associated with the noble gases and radioiodines would be considerably less. In consideration of the present unknown specifics associated with this event, it was deemed conservative and appropriate to select the release fractions for both the nobles and the radioiodines as 1.0. Fission product yields from Table 6-9 of Ref. 13 (a plutonium solution of unknown isotopics for a reference yield of $1 \times 10^{19}$ fissions) were selected, and consideration of the selected yield of $1 \times 10^{18}$ fissions resulted in scaling the source terms.

The chosen source term specifics for the evaluation basis criticality event are shown in Table 16. As previously discussed a conservative fission yield (moderated vs dry criticality) was combined with a conservative release fraction (for a powder vs moderated criticality). Thus, the source term in Table 16 is judged to be very conservative. The release height should be selected as the appropriate stack height for the facility where dose consequences are being calculated. The leak-path factor was taken as 1.0.

\subsubsection{Frequency estimate}

Criticalities have occurred considerably less frequently than in the earlier days of nuclear research, development, and operations. A number of these accidents are discussed in Ref. 18. None of these accidents are specifically associated with dry plutonium powder. However, several accidents involving dry metal, moderated metals, and fuel rods have occurred during the last 50 years. The fact that $30-40$ criticalities in the United States have historically (mostly in the 1940s, 1950s, and 1960s) occurred suggests that the accident spectrum analyzed for this facility should contain a criticality at a low estimated frequency. As was the case in Ref. 10, a frequency estimate of extremely unlikely $\left(1 \times 10^{-4}\right.$ to $1 \times 10^{-6}$ /year) is still judged to be appropriate for this event. However, the frequency of this event is judged to be somewhat less (perhaps 1 order of mignitude) than that at the large plant (100 MT/year vs $2 \mathrm{MT} / \mathrm{year}$ ) because of the simplicity of the LA plant and the lower amounts of fissile material being handled. 
Table 16. Source term for the evaluation basis criticality event (stack release with a relatively short duration)

\begin{tabular}{lc}
\hline Isotope & $\begin{array}{c}\text { Released radioactivity } \\
\text { (Ci) }\end{array}$ \\
\hline $83 \mathrm{~m}_{\mathrm{Kr}}$ & $1.1 \times 10^{1}$ \\
$83 \mathrm{~m} \mathrm{Kr}$ & $7.1 \times 10$ \\
$85_{\mathrm{Kr}}$ & $8.1 \times 10^{-4}$ \\
$87_{\mathrm{Kr}}$ & $4.3 \times 10^{1}$ \\
$88 \mathrm{Kr}$ & $2.3 \times 10^{1}$ \\
$89 \mathrm{Kr}$ & $1.3 \times 10^{3}$ \\
$131 \mathrm{~m} \mathrm{Xe}$ & $1.0 \times 10^{-2}$ \\
$133 \mathrm{~m} \mathrm{Xe}$ & $2.2 \times 10^{-1}$ \\
$133 \mathrm{Xe}$ & $2.7 \times 10$ \\
$135 \mathrm{~m} \mathrm{Xe}$ & $3.3 \times 10^{2}$ \\
$135 \mathrm{Xe}$ & $4.1 \times 10^{1}$ \\
$137 \mathrm{Xe}$ & $4.9 \times 10^{3}$ \\
$138 \mathrm{Xe}$ & $1.1 \times 10^{3}$ \\
$131_{\mathrm{I}}$ & $1.1 \times 10$ \\
$132 \mathrm{I}$ & $1.2 \times 10^{2}$ \\
$133_{\mathrm{I}}$ & $1.6 \times 10^{1}$ \\
$134 \mathrm{I}$ & $4.3 \times 10^{2}$ \\
$135 \mathrm{I}$ & $4.5 \times 10^{1}$ \\
\hline
\end{tabular}

\subsubsection{Evaluation Basis Seismic Event}

\subsubsection{Discussion}

A seismic event appropriate for the facility's evaluation basis was selected. In this event, major portions of the process line glove boxes are assumed to be breached with the contents available for release. In such an event, the focus was on the dispersible powders that would be at the powder blending stations. The storage vault and receiving area are assumed to have suitable containers for plutonium oxide that will survive the earthquake ( 3013 cans with double containment). ${ }^{15}$ In-process material in glove boxes is, however, more vulnerable as are powder storage areas that may exist. Finished pellets and fuel rods are thought to be generally nondispersible even though they may escape the glove boxes. In this seismic event, the glove boxes are breached and assumed to fail based on a scenario of falling debris and equipment inside the room. The building confinement and ventilation system are assumed to remain intact, resulting in a filtered stack release.

\subsubsection{Source term}

Because the material in the vault is assumed to be in 3013 cans (which have double containment), no material was judged to be released from this area in this event. Table 17 shows the materials in process along with the release fractions and respirable fractions that were used. The total isotopic source term is shown summarized at the bottom for each plutonium isotope, as is the total amount of plutonium released. Because only $32 \mathrm{~kg}$ of plutonium oxide is allowed in a single batch, it was assumed that this batch was split in inventory between the master mix and fuel blend mix stations. This material was assumed to be in temporary storage cans at their respective stations. Another $10 \mathrm{~kg}$ of plutonium oxide in the form of powder is assumed to be at risk and open within the glove box. This material is from two cans that are taken out of the vault and prepared for loading (no credit for the 3013 can double containment). 
Table 17. Source term for the evaluation basis seismic event

\begin{tabular}{|c|c|c|c|c|c|c|c|c|c|c|c|c|}
\hline $\begin{array}{l}\text { Pícessiing } \\
\text { station }\end{array}$ & $\begin{array}{c}\text { Material at } \\
\text { risk } \\
(\mathrm{g})\end{array}$ & $\begin{array}{l}\text { Physical } \\
\text { form }\end{array}$ & $\begin{array}{c}\text { Damage } \\
\text { ratio }\end{array}$ & $\begin{array}{l}\text { Airtevinic } \\
\text { release } \\
\text { fraction }\end{array}$ & $\begin{array}{l}\text { Respirable } \\
\text { fraction }\end{array}$ & $\begin{array}{l}\text { Leak-path } \\
\text { factor }\end{array}$ & ${ }^{238 \mathrm{Pu}}$ & $\begin{array}{l}{ }^{239} \mathrm{Pu} \\
\text { released }\end{array}$ & $\begin{array}{l}{ }^{240} \mathrm{Pu} \\
\text { released }\end{array}$ & $\begin{array}{l}{ }^{241} \mathrm{Pu} \\
\text { released }\end{array}$ & $\begin{array}{l}{ }^{242} \mathrm{Pu} \\
\text { released }\end{array}$ & $\begin{array}{l}{ }^{241} \mathrm{Am} \\
\text { released }\end{array}$ \\
\hline $\begin{array}{l}\text { Plutonium oxide } \\
\text { ( } 2 \text { cans) }\end{array}$ & 10,000 & $\begin{array}{l}\text { Fine powder } \\
\mathrm{PuO}_{2}\end{array}$ & 1.00 & $1.00 \times 10^{-2}$ & 0.20 & $1.00 \times 10^{-5}$ & $9.06 \times 10^{-7}$ & $1.01 \times 10^{-5}$ & $2.59 \times 10^{-6}$ & $9.08 \times 10^{-6}$ & $6.93 \times 10^{-10}$ & $5.44 \times 10^{-6}$ \\
\hline $\begin{array}{l}\text { Master mix } \\
\text { powder storage }\end{array}$ & 53,000 & $\begin{array}{l}\text { Fine powder } \\
\text { MOX ( } 30 \% \\
\text { blend) }\end{array}$ & 1.00 & $1.00 \times 10^{-3}$ & 0.10 & $1.00 \times 10^{-5}$ & $7.20 \times 10^{-8}$ & $8.02 \times 10^{-7}$ & $2.06 \times 10^{-7}$ & $7.22 \times 10^{-7}$ & $5.51 \times 10^{-11}$ & $4.33 \times 10^{-7}$ \\
\hline $\begin{array}{l}\text { MOX blend } \\
\text { storage }\end{array}$ & 160,000 & $\begin{array}{l}\text { Fine powder } \\
\text { MOX (10\% } \\
\text { blend) }\end{array}$ & 1.00 & $1.00 \times 10^{-3}$ & 0.10 & $1.00 \times 10^{-5}$ & $7.25 \times 10^{-8}$ & $8.07 \times 10^{-7}$ & $2.07 \times 10^{-7}$ & $7.27 \times 10^{-7}$ & $5.54 \times 10^{-11}$ & $4.35 \times 10^{-7}$ \\
\hline \multicolumn{7}{|c|}{$\begin{array}{l}\text { Total isotopic source term, Ci } \\
\text { Total source term, } \mathrm{Pu} / \mathrm{Am} \text { mix, } \mathrm{g}\end{array}$} & $1.05 \times 10^{-6}$ & $\begin{array}{l}1.17 \times 10^{-5} \\
2.0454 \times 10^{-4}\end{array}$ & $3.00 \times 10^{-6}$ & $1.05 \times 10^{-5}$ & $8.03 \times 10^{-10}$ & $6.31 \times 10^{-6}$ \\
\hline
\end{tabular}


In a seismic event, powders in various pieces of equipment will be subjected to many different damage ratios and release fractions. For the pure oxide powder at the feed station, the entire amount was conservatively subjected to a release fraction corresponding to debris falling into powder (no credit for the two open cans, utilizing a $1 \times 10^{-2}$ airborne release fraction and a 0.2 respirable fraction for the total release fraction from Ref. 13). With respect to the 32-kg batch of in-process powder, the powder stored in interim containers is assumed to be subjected to damage. A $1 \times 10^{-3}$ airborne release fraction and a 0.1 respirable fraction for the total release fraction was selected from Ref. 13 based on falling equipment impacting storage cans of powder. No credit is taken for the glove boxes that were postulated to fail. However, other portions of the process operation were assumed to be resistant to the event because of the material form. Finished pellets and fuel rods were not considered to constitute a significant portion of dispersible material. The source term is assumed to be filtered (leak-path factor of $1 \times 10^{-5}$ ) and released to a stack.

\subsubsection{Frequency estimate}

The frequency estimate for this event varies widely, depending on the site selected (and its respective seismic profile), the building used (and its evaluation basis), and the internal arrangement of equipment (see Sect. 7.5). Generally, a frequency estimate of $1 \times 10^{-2}$ to $1 \times 10^{-4}$ is used for this event (the frequency is usually closer to lower end of this range).

\subsubsection{Evaluation Basis Fire Event}

\subsubsection{Discussion}

A large spectrum of fire events ranging from small fires with no impacts to large multiroom fires with major impacts can be postulated for the LA fabrication building. Unlike the large MOX fabrication facility, the LA mission will take place in an existing building. While many existing buildings within the DOE complex are adequately covered by an existing fire protection program, it is reasonable to conclude that existing buildings might be more susceptible to fires (as compared to a new facility where fire protection can be incorporated into the design). However, the existing buildings must still meet the appropriate DOE orders.

A source of combustible material such as hydraulic fluid, alcohol, contaminated combustibles, or some other material is assumed to be present in the room. In addition, adjoining facilities such as offices may exist in the building and add to the risk of fires in the facility. The glove boxes are assumed to fail in the fire. This event is assumed to be a moderate-size room fire. The MOX powder that is in interim storage is assumed to be at risk and subjected to the thermal stress of the fire, because the glove box fails. Because of the limited combustible material and/or the existence of mitigators such as a fire protection system or -arrival of the firefighting unit, the event is assumed to be terminated. The severity of this fire is not enough to jeopardize the overall confinement characteristics of the building.

\subsubsection{Source term}

Table 18 shows the materials in process along with the release fractions that were used. With respect to the oxide containers $(10 \mathrm{~kg})$, a high release fraction was selected based on a pressurized gas release combined with powder. This corresponds to a highly pressurized, strong, single can that ruptures under a high thermal stress because of pressure and ejects powder from the breached container. A $10 \%$ damage ratio (thus, $500 \mathrm{~g}$ of powder are subjected to the release fraction) was selected on the basis that the release fraction does not apply universally to all of the powder in the can (the release fraction will go down as larger cans of powder are subjected to the energetics).

The 32-kg inventory in the process area was assumed to be evenly split between the master mix and MOX fuel blend storage areas. The entire interim storage inventory of MOX powder is assumed to be subjected to a release fraction corresponding to thermal stress $\left(6 \times 10^{-3}\right.$ airborne release fraction and a 0.01 respirable fraction from Ref. 13). Green pellets, finished pellets, and fuel rods were not considered to constitute a significant portion of dispersible material. The material is assumed to be filtered and released to a stack. The scrap area was assumed to contain mostly solid material and was not judged to 
Table 18. Source term for the evaluation basis fire

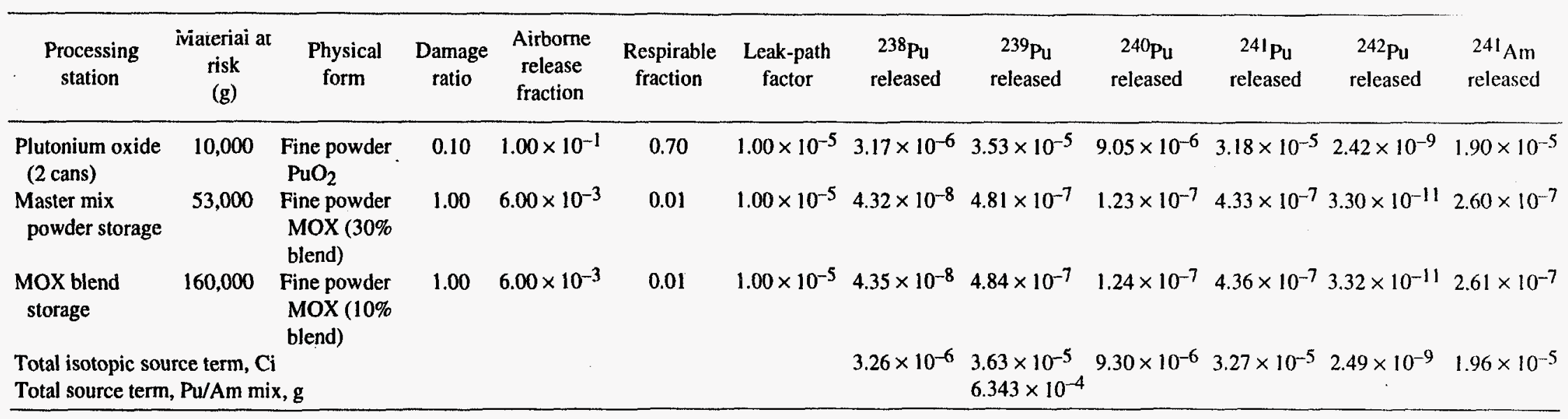


be a significant source of dispersible material. As with other source terms no credit was taken for in-facility filters, as these may fail because of the fire. The source term is filtered and released to a stack.

\subsubsection{Frequency estimate}

The frequency estimate of fires depends on the conduct of operations, the building selected, the adequacy of the fire protection program, and a number of other variables. A frequency estimate of between $1 \times 10^{-2}$ /year and $1 \times 10^{-2}$ /year (unlikely) is judged to be appropriate for this event because a relatively small area is assumed to be involved.

\subsubsection{Evaluation Basis Explosion Event}

\subsubsection{Discussion}

As was the case in Ref. 10, an explosion event was postulated for the sintering furnace in the LA fabrication facility. A nonexplosive mixture of $6 \%$ hydrogen and $94 \%$ argon is used in the furnace. Multiple equipment and operator errors would have to occur to enable an explosive mixture of hydrogen mixed with air to build up in the box. As a result of the explosion, green pellets are assumed to be subjected to the direct force of the resultant shock waves. Unlike Ref. 10, where the facility layout can accommodate segregation (in effect limiting the explosion damage), it is assumed that the glove boxes involved in powder blending are damaged indirectly by the explosion. It is not expected that the shock wave impacting this area would be severe enough to significantly damage all of the storage inventory because interim storage cans would provide some mitigation.

\subsubsection{Source term}

The split in the material at risk (between green pellets, pellets in the furnace, and powder storage areas) is shown in Table 19 for the $32-\mathrm{kg}$ batch. No specific release fractions are given in the literature for deflagration forces on green pellets that are pressed to $\sim 60 \%$ theoretical density. Reference 13, Sect. 4.3.3, discusses a formulation for determining the product of the airborne release fraction and respirable fraction $\left(A R F^{*} R F\right.$ ) for dropped uranium dioxide pellets. A release fraction (combined ARF*RF) of $1 \times 10^{-4}$ was deemed to be conservative for all material $(40,000 \mathrm{~g})$ in the furnace subjected to explosive forces. This same release and respirable fraction was also used for the green pellets that would be pressed and likely near the furnace. The $80,000 \mathrm{~g}$ of green pellets would be a little further from the blast and in trays or containers. The same release fraction was applied to these green pellets and is thought to be conservative.

The remaining part of the $20-\mathrm{kg}$ batch was assumed to be split between the MOX master blend and powder storage stations. The MOX powder in the blending areas would likely be in a different glove box and somewhat removed from the blast. These glove boxes are assumed to be indirectly damaged from the explosion. As previously stated, most of the storage powder would be in interim cans that would merely be displaced. Powders in a glove box that undergo damage from external explosions are discussed in Ref. 13 (p. 4-69). A release fraction (and respirable fraction) of $5 \times 10^{-3}$ (and 0.3) was used and conservatively applied to all of the powder. The total source term is shown in Table 19. The building confinement is judged to be still intact resulting in a filtered stack release.

\subsubsection{Frequency estimate}

Because no definitive designs for the furnace and glove boxes currently exist, estimation of the probability of this event is difficult at this time. A judgment was made that the frequency of this event is extremely unlikely (between $1 \times 10^{-4} /$ year and $1 \times 10^{-6} /$ year). Such an explosion of sufficient size from the furnace to impact the glove boxes would only be possible because of a combination of equipment failure and human error. 
Table 19. Source term for the evaluation basis explosion

\begin{tabular}{|c|c|c|c|c|c|c|c|c|c|c|c|c|}
\hline $\begin{array}{l}\text { Processing } \\
\text { station }\end{array}$ & $\begin{array}{l}\text { Material at } \\
\text { risk } \\
(\mathrm{g})\end{array}$ & $\begin{array}{l}\text { Physical } \\
\text { form }\end{array}$ & $\begin{array}{c}\text { Damage } \\
\text { ratio }\end{array}$ & $\begin{array}{l}\text { Airborne } \\
\text { release } \\
\text { fraction }\end{array}$ & $\begin{array}{l}\text { Respirable } \\
\text { fraction }\end{array}$ & $\begin{array}{l}\text { Leak-path } \\
\text { factor }\end{array}$ & ${ }^{238} \mathrm{Pu}$ & $\begin{array}{l}{ }^{239} \mathrm{Pu} \\
\text { released }\end{array}$ & $\begin{array}{l}240 \mathrm{Pu} \\
\text { released }\end{array}$ & $\begin{array}{l}241 \mathrm{Pu} \\
\text { released }\end{array}$ & $\begin{array}{l}{ }^{242} \mathrm{Pu} \\
\text { released }\end{array}$ & $\begin{array}{l}{ }^{241} \mathrm{Am} \\
\text { released }\end{array}$ \\
\hline $\begin{array}{l}\text { Master mix } \\
\text { powder storage }\end{array}$ & 33,000 & $\begin{array}{l}\text { Fine powder } \\
\text { MOX ( } 30 \% \\
\text { blend) }\end{array}$ & 1.00 & $5.00 \times 10^{-3}$ & 0.3 & $1.00 \times 10^{-5}$ & $6.73 \times 10^{-7}$ & $7.49 \times 10^{-6}$ & $1.92 \times 10^{-6}$ & $6.75 \times 10^{-6}$ & $5.14 \times 10^{-10}$ & $4.04 \times 10^{-6}$ \\
\hline $\begin{array}{l}\text { MOX blend } \\
\text { storage }\end{array}$ & 100,000 & $\begin{array}{l}\text { Fine powder } \\
\text { MOX (10\% } \\
\text { blend) }\end{array}$ & 1.00 & $5.00 \times 10^{-3}$ & 0.3 & $1.00 \times 10^{-5}$ & $6.79 \times 10^{-7}$ & $7.57 \times 10^{-6}$ & $1.94 \times 10^{-6}$ & $6.81 \times 10^{-6}$ & $5.19 \times 10^{-10}$ & $4.08 \times 10^{-6}$ \\
\hline $\begin{array}{l}\text { MOX green } \\
\text { pellet storage } \\
\text { (in pellet press } \\
\text { area) }\end{array}$ & 80,000 & $\begin{array}{l}\text { Pressed to } 0.6 \\
\text { TD, MOX } \\
\text { (10\% blend) }\end{array}$ & 1.00 & $1.00 \times 10^{-4}$ & 1 & $1.00 \times 10^{-5}$ & $3.62 \times 10^{-8}$ & $4.04 \times 10^{-7}$ & $1.03 \times 10^{-7}$ & $3.63 \times 10^{-7}$ & $2.77 \times 10^{-11}$ & $2.18 \times 10^{-7}$ \\
\hline $\begin{array}{l}\text { Pellet sintering } \\
\text { furnace }\end{array}$ & 40,000 & $\begin{array}{l}\text { Assume all } \\
\text { green pellets } \\
\text { MOX (10\% } \\
\text { blend) }\end{array}$ & 1.00 & $1.00 \times 10^{-4}$ & 1 & $1.00 \times 10^{-5}$ & $1.81 \times 10^{-8}$ & $2.02 \times 10^{-7}$ & $5.17 \times 10^{-8}$ & $1.82 \times 10^{-7}$ & $1.39 \times 10^{-11}$ & $1.09 \times 10^{-7}$ \\
\hline \multicolumn{7}{|c|}{$\begin{array}{l}\text { Total isotopic source term, } \mathrm{Ci} \\
\text { Total source term, Pu/Am mix, } \mathrm{g}\end{array}$} & $1.41 \times 10^{-6}$ & $\begin{array}{l}1.57 \times 10^{-5} \\
2.739 \times 10^{-4}\end{array}$ & $4.02 \times 10^{-6}$ & $1.41 \times 10^{-5}$ & $1.08 \times 10^{-9}$ & $8.45 \times 10^{-6}$ \\
\hline
\end{tabular}




\subsubsection{Beyond-Evaluation Basis Seismic Event}

\subsubsection{Discussion}

In this analysis an event much more severe in consequences than what might be expected to be the design basis (or evaluation basis) is examined. For some existing DOE facilities, the estimated seismic frequency for beyond-design basis events can be greater than $1 \times 10^{-6} /$ year. The design basis for every building in the complex varies considerably depending on site specifics and the type of construction used in the building. A damage assessment of the facility is further complicated by the fact that seismic considerations could also be incorporated in the glove box design of the facility. In reality, such a catastrophic event may or may not demolish the building and/or the glove boxes. However, for the purposes of illustrating a high consequence accident (which occurs at a very low frequency), total demolition of the building has been assumed. In this event, no credit is taken for the building, the filters, or the glove boxes.

\subsubsection{Source term}

In the evaluation basis seismic event previously discussed, credit was taken for the 3013 cans (which have double containment) in the vault storage area. In this event, however, a total building collapse is used, and a judgment was made that a few of the containers may fail. A damage ratio of 0.05 was used; it equates to 4 out of 80 cans in the vault area. For the source term evaluation of the remainder of the in-process material (including the two cans that feed the process), the release fractions were selected to be the same as in the evaluation basis seismic event. However, because it is assumed that the building collapses and the ventilation system is severed, no credit is taken for filtration. This results in a building leak-path factor of 1.0. The source term is assumed to be released at or near ground level $(10 \mathrm{~m})$. Table 20 shows the source term for this event.

\subsubsection{Frequency}

As discussed previously there is great difficulty in assigning a frequency for this event, especially because facilities are not analyzed for very high seismic events that occur with very infrequent return periods. Site specifics make the frequency assessment of this event very uncertain as well. For the sake of this analysis, a frequency value of $1 \times 10^{-6}$ or less is thought to be appropriate for the EIS purposes.

\subsubsection{Beyond-Evaluation Basis Major Building Fire}

\subsubsection{Discussion}

Fuel manufacturing operations do not lend themselves to the use of large significant amounts of combustible material. In this scenario, however, it is assumed that the building is burned for a considerable length of time, resulting in a total collapse of the building. This event could also roughly be characterized as a large fire following a total building collapse.

\subsubsection{Source term}

Some thought was given to the stability of the 3013 cans in the vault which would be subjected to prolonged heat during a large fire. Because of the double containment and high-pressure rating for the cans, it was judged that the cans could withstand a large building fire. However, because a major building fire breaches the confinement, it is assumed that the building structure could collapse. This happens in large buildings subjected to high heat loads for long periods of time. As a result of this consideration, four of the cans in the vault area were assumed to have breached, just as in the beyond-evaluation seismic event. For the two oxide cans in process, it was conservatively assumed that they burst (previously discussed in the evaluation-basis fire scenario). The remainder of the $32-\mathrm{kg}$ inventory was assumed to be subjected to a 
Table 20. Source term for beyond the evaluation basis seismic event (total building collapse assumed)

\begin{tabular}{|c|c|c|c|c|c|c|c|c|c|c|c|c|}
\hline $\begin{array}{l}\text { Processing } \\
\text { station }\end{array}$ & $\begin{array}{c}\text { Material at } \\
\text { risk } \\
\text { (g) }\end{array}$ & $\begin{array}{l}\text { Physical } \\
\text { form }\end{array}$ & $\begin{array}{c}\text { Damage } \\
\text { ratic }\end{array}$ & $\begin{array}{l}\text { Airborne } \\
\text { release } \\
\text { fraction }\end{array}$ & $\begin{array}{l}\text { Respirable } \\
\text { ffäciiun }\end{array}$ & $\begin{array}{l}\text { Leak-path } \\
\text { ractor }\end{array}$ & $\begin{array}{l}{ }^{238} \mathrm{Pu} \\
\text { released }\end{array}$ & $\begin{array}{l}{ }^{239} \mathrm{Pu} \\
\text { released }\end{array}$ & $\begin{array}{l}{ }^{240} \mathrm{Pu} \\
\text { released }\end{array}$ & ${ }_{\text {released }}^{24 l} \mathrm{Pu}$ & $\begin{array}{l}{ }^{242} \mathrm{Pu} \\
\text { released }\end{array}$ & $\begin{array}{l}24 l_{\mathrm{Am}} \\
\text { released }\end{array}$ \\
\hline $\begin{array}{l}\text { Plutonium } \\
\text { storage vault }\end{array}$ & 400,000 & $\begin{array}{l}\text { Fine powder } \\
\mathrm{PuO}_{2}\end{array}$ & 0.05 & $1.00 \times 10^{-3}$ & 0.10 & $1.00 \times 10^{0}$ & $9.06 \times 10^{-3}$ & $1.01 \times 10^{-1}$ & $2.59 \times 10^{-2}$ & $9.08 \times 10^{-2}$ & $6.93 \times 10^{-6}$ & $5.44 \times 10^{-2}$ \\
\hline $\begin{array}{l}\text { Plutonium oxide } \\
\text { ( } 2 \text { cans) }\end{array}$ & 10,000 & $\begin{array}{l}\text { Fine powder } \\
\mathrm{PuO}_{2}\end{array}$ & 1.00 & $1.00 \times 10^{-2}$ & 0.20 & $1.00 \times 10^{0}$ & $9.06 \times 10^{-2}$ & $1.01 \times 10^{0}$ & $2.59 \times 10^{-1}$ & $9.08 \times 10^{1}$ & $6.93 \times 10^{-5}$ & $5.44 \times 10^{-1}$ \\
\hline $\begin{array}{l}\text { Master mix } \\
\text { powder storage }\end{array}$ & 53,000 & $\begin{array}{l}\text { Fine powder } \\
\text { MOX ( } 30 \% \\
\text { blend) }\end{array}$ & 1.00 & $1.00 \times 10^{-3}$ & 0.10 & $1.00 \times 10^{0}$ & $7.20 \times 10^{-3}$ & $8.02 \times 10^{-2}$ & $2.06 \times 10^{-2}$ & $7.22 \times 10^{-2}$ & $5.51 \times 10^{-6}$ & $4.33 \times 10^{-2}$ \\
\hline $\begin{array}{l}\text { MOX blend } \\
\text { storage }\end{array}$ & 160,000 & $\begin{array}{l}\text { Fine powder } \\
\text { MOX (10\% } \\
\text { blend })\end{array}$ & 1.00 & $1.00 \times 10^{-3}$ & 0.10 & $1.00 \times 10^{0}$ & $7.25 \times 10^{-3}$ & $8.07 \times 10^{-2}$ & $2.07 \times 10^{-2}$ & $7.27 \times 10^{-2}$ & $5.54 \times 10^{-6}$ & $4.35 \times 10^{-2}$ \\
\hline \multicolumn{7}{|c|}{$\begin{array}{l}\text { Total isotopic soutce term, } \mathrm{Ci} \\
\text { Total source term, } \mathrm{Pu} / \mathrm{Am} \text { mix }, \mathrm{g}\end{array}$} & $1.14 \times 10^{-1}$ & $\begin{array}{l}1.27 \times 10^{0} \\
22.22\end{array}$ & $3.26 \times 10^{-1}$ & $1.14 \times 10^{-0}$ & $8.72 \times 10^{-5}$ & $6.85 \times 10^{-1}$ \\
\hline
\end{tabular}


release fraction corresponding to falling debris in cans (similar to a seismic event). The total estimated source term is shown in Table 21 . However, because considerable heat is produced by the fire, a significant plume rise would occur. Therefore, a release height of $100 \mathrm{~m}$ was judged to be appropriate for this event.

\subsubsection{Frequency}

Assigning a frequency for this event is difficult because significant combustible loads are not placed in close proximity to the process. This is a very low frequency noncredible event, which requires the introduction of significant combustibles that would create a fire large enough to collapse the structure. For the sake of this analysis, a frequency value of much less than $1 \times 10^{-7}$ is thought to be appropriate for the EIS purposes.

\subsection{EVALUATION OF POTENTIAL CHEMICAL SOURCE TERMS}

Chemical and radiological materials used in this facility were previously given in Table 8 . With respect to radiological effects, the source terms associated with plutonium oxide constitute an overwhelming majority of the radiological risk. With respect to the chemical hazards associated with depleted $\mathrm{UO}_{2}$ (which are released in conjunction with the plutonium oxide in the scenarios outlined in the previous sections), no specific source terms have been generated in this analysis. As discussed in previous sections, only small amounts of plutonium (generally $<1 \mathrm{~g}$ ) constitute the source terms. If treated similarly (from a release standpoint), small amounts of the depleted uranium that may accompany the plutonium oxide that escapes the building are judged to be inconsequential.

Table 8 also gives the other chemicals and compounds that will be used annually by the facility and lists the yearly consumption of gases, liquids, and solids. With respect to any possibly chemical source term, the gases listed (i.e., helium, hydrogen, nitrogen, and oxygen) do not constitute an inhalation or exposure hazard in the context of LA fabrication operations. Reportable quantities of various chemical compounds are cited in 40 CFR 302, Table 302.4. If a chemical company operator spills less than these quantities, the Environmental Protection Agency is not notified. While this is not an absolute criterion that guarantees the lack of off-site consequences, it is illustrative to examine the yearly flow of chemicals based on these reported quantities.

Table 22 compares the annual usage of chemicals to the reportable quantities for that material. While not all materials are listed, the comparison shows that the LA facility does not constitute a major source of chemical inventories. The chemicals listed are either in a liquid or solid form, and the gases listed are not hazardous from an inhalation perspective. Typical occupational chemical exposure incidents, such as acid burns to a worker, are certainly credible. A significant release scenario (inhalation risk, ingestion risk, or skin contact risk) that constitutes a source term (with a magnitude of reasonable concern) to a receptor is difficult to credibly postulate at this stage of the facility analysis. Because of the small size of the facility -and the small quantities of chemicals that are expected to be on hand, it is concluded that no chemical source terms are worthy of analysis (that are beyond what is found in small standard industrial facilities). The amounts that would be in use by this facility are certainly considered to be well within the scope of typical industrial hazards found in laboratory environments.

\subsection{SITE SPECIFICS FOR THE LANL PF-4 BUILDING}

\subsubsection{Stack Release Height}

For Building PF-4, the stack release height is $\sim 14 \mathrm{~m}(\sim 46 \mathrm{ft})$.

\subsubsection{Evaluated Seismic Attributes}

For the PF-4 building, the current peak ground acceleration value of the evaluated basis earthquake is $0.33 \mathrm{~g}$, with an estimated frequency of less than 1 every 2,000 years $\left(5 \times 10^{-4} /\right.$ year) (Ref. 3, Table 2-14). This estimate does not consider the equipment specifics that would be involved in the MOX LA fabrication 
Table 21. Source term for beyond the evaluation basis major building fire/building collapse (total building collapse assumed to result; source term release height $\mathbf{= 1 0 0} \mathbf{m}$ )

\begin{tabular}{|c|c|c|c|c|c|c|c|c|c|c|c|c|}
\hline $\begin{array}{l}\text { Processing } \\
\text { station }\end{array}$ & $\begin{array}{l}\text { Material at } \\
\text { risi } \\
(\mathrm{g})\end{array}$ & $\begin{array}{l}\text { Physical } \\
\text { form }\end{array}$ & $\begin{array}{l}\text { Damage } \\
\text { ratio }\end{array}$ & $\begin{array}{l}\text { Airborne } \\
\text { release } \\
\text { fraction }\end{array}$ & $\begin{array}{l}\text { Respirable } \\
\text { fraction }\end{array}$ & $\begin{array}{l}\text { Leak path } \\
\text { factor }\end{array}$ & ${ }^{238 \mathrm{Pii}}$ & ${ }^{339} \mathrm{Fu}$ & $\begin{array}{l}240 \mathrm{pu} \\
\text { released }\end{array}$ & $\begin{array}{l}21 ! \text { Fu } \\
\text { released }\end{array}$ & $\begin{array}{l}242 \mathrm{Pu} \\
\text { released }\end{array}$ & $\begin{array}{l}2+i \mathrm{Am} \\
\text { released }\end{array}$ \\
\hline $\begin{array}{l}\text { Plutonium } \\
\text { storage vault }\end{array}$ & 400,000 & $\begin{array}{l}\text { Fine powder } \\
\mathrm{PuO}_{2}\end{array}$ & 0.05 & $1.00 \times 10^{-3}$ & 0.10 & $1.00 \times 10^{0}$ & $9.06 \times 10^{-3}$ & $1.01 \times 10^{-1}$ & $2.59 \times 10^{-2}$ & $9.08 \times 10^{-2}$ & $6.93 \times 10^{-6}$ & $5.44 \times 10^{-2}$ \\
\hline $\begin{array}{l}\text { Plutonium oxide } \\
\text { ( } 2 \text { cans) }\end{array}$ & 10,000 & $\begin{array}{l}\text { Fine powder } \\
\mathrm{PuO}_{2}\end{array}$ & 0.10 & $1.00 \times 10^{-1}$ & 0.70 & $1.00 \times 10^{0}$ & $3.17 \times 10^{-1}$ & $3.53 \times 10^{0}$ & $9.05 \times 10^{-1}$ & $3.18 \times 10^{0}$ & $2.42 \times 10^{-4}$ & $1.90 \times 10^{0}$ \\
\hline $\begin{array}{l}\text { Master mix } \\
\text { powder storage }\end{array}$ & 53,000 & $\begin{array}{l}\text { Fine powder } \\
\text { MOX (30\% } \\
\text { blend) }\end{array}$ & 1.00 & $1.00 \times 10^{-3}$ & 0.10 & $1.00 \times 10^{0}$ & $7.20 \times 10^{-3}$ & $8.02 \times 10^{-2}$ & $2.06 \times 10^{-2}$ & $7.22 \times 10^{-2}$ & $5.51 \times 10^{-6}$ & $4.33 \times 10^{-2}$ \\
\hline $\begin{array}{l}\text { MOX blend } \\
\text { storage }\end{array}$ & 160,000 & $\begin{array}{l}\text { Fine powder } \\
\text { MOX }(10 \% \\
\text { blend) }\end{array}$ & 1.00 & $1.00 \times 10^{-3}$ & 0.10 & $1.00 \times 10^{0}$ & $7.25 \times 10^{-3}$ & $8.07 \times 10^{-2}$ & $2.07 \times 10^{-2}$ & $7.27 \times 10^{-2}$ & $5.54 \times 10^{-6}$ & $4.35 \times 10^{-2}$ \\
\hline \multicolumn{7}{|c|}{$\begin{array}{l}\text { Total isotopic source term, } \mathrm{Ci} \\
\text { Total source term, Pu/Am mix, g }\end{array}$} & $3.41 \times 10^{-1}$ & $\begin{array}{l}3.79 \times 10^{0} \\
66.32\end{array}$ & $9.72 \times 10^{-1}$ & $3.42 \times 10^{0}$ & $2.60 \times 10^{-4}$ & $2.05 \times 10^{0}$ \\
\hline
\end{tabular}


Table 22. Comparison of LA facility annual usage and reportable quantity per 40 CFR 302

\begin{tabular}{lcl}
\hline \multicolumn{1}{c}{ Item } & $\begin{array}{c}\text { Annual average } \\
\text { consumption }\end{array}$ & $\begin{array}{c}\text { Reportable } \\
\text { quantity }\end{array}$ \\
\hline Liquids & & \\
Hydrochloric acid & $1 \mathrm{lb}$ & $5,000 \mathrm{lb}$ \\
Nitric acid & $2 \mathrm{lb}$ & $1,000 \mathrm{lb}$ \\
Polyethylene glycol & $<45 \mathrm{lb}$ & Not listed \\
Sulfuric acid & $5 \mathrm{lb}$ & $1,000 \mathrm{lb}$ \\
Solids & $34 \mathrm{lb}$ & $1,000 \mathrm{lb}$ \\
Sodium hydroxide & $<200 \mathrm{lb}$ & Not listed \\
Sodium nitrate & $<45 \mathrm{lb}$ & Not listed \\
Zinc stearate & & \\
Nonprocess chemicals & $60 \mathrm{gal}$ & Not listed \\
Alcohol & $10 \mathrm{lb}$ & Not listed \\
Hydraulic fluid & 60 gal & Not listed \\
General cleaning fluids & & \\
\hline
\end{tabular}

line and represents an estimate for the building and confinement-related ventilation system. Crosscomparisons of frequencies and evaluation basis values for sites must be performed with caution. Such simple comparisons do not take into account the differences in analytical approaches that were used at each site to estimate the building response, acceleration, or estimated frequency for the site. As a general rule for all sites, it is expected that the evaluation basis frequency for a seismic event would be from $1 \times 10^{-2} /$ year to $1 \times 10^{-4} /$ year and would likely be between $1 \times 10^{-3} /$ year and $1 \times 10^{-4} /$ year. 


\section{Page Intentionally Blank}




\section{TRANSPORTATION}

\subsection{OPERATIONS-RELATED TRANSPORTATION REQUIREMENTS}

Production of MOX fuel LAs, irradiation of the LAs in commercial reactors, and subsequent PIE will result in a number of packaging and transportation operations to (1) obtain the necessary feed materials to manufacture LAs, (2) package and transport the completed fuel assemblies from the fabrication facility to the commercial reactor, and (3) package and transport the irradiated fuel assemblies from the commercial reactor to another facility for PIE.

Plans for MOX fuel LA testing involve manufacture of up to ten MOX fuel LAs, with up to eight LAs undergoing irradiation while the remaining LAs are maintained as unirradiated archives. Each LA could contain from as few as one-third MOX rods (with the balance of the rods being LEU) to an entire assembly composed of MOX rods. Under these circumstances, production of LA will require that LEU and MOX fuel rods be combined in a single assembly. This activity could occur at either the LA fabrication facility or at the reactor facility. While reactors generally have the ability to substitute individual rods within an assembly (due to detected damage), it is expected that exchanging as many as one-third of the LEU assembly rods with MOX rods would occur at the LA facility.

\subsubsection{Feed Materials}

Table 23 provides information about the shipment of $\mathrm{PuO}_{2}$. Table 24 provides information about the shipment of depleted $\mathrm{UO}_{2}$. Depleted $\mathrm{UO}_{2}$ can be obtained by the consortium, or DOE will provide either depleted uranium fluoride $\left(\mathrm{DUF}_{6}\right)$ or depleted uranium oxide $\left(\mathrm{DUO}_{3}\right)$ for conversion by the consortium. Other materials (e.g., new empty fuel rods, end plugs, grid spacers, and other assembly hardware) are not "regulated" materials for transportation. Their shipment would not require special packaging, other than to protect the economic value of the commodity. The specific LA design is uncertain. Some designs may have every fuel rod contain MOX, while other designs may have both $\mathrm{MOX}$ and $\mathrm{UO}_{2}$ fuel rods within a bundle. In the latter case, it would be necessary to either ship enriched $\mathrm{UO}_{2}$ fuel rods (or $\mathrm{UO}_{2}$ fuel rods in LEU fuel assemblies) to the MOX fabrication facility or to ship MOX fuel rods from the fabrication facility to the commercial fuel fabrication site (for insertion in LEU fuel assemblies shipped separately to the reactor). If the MOX LA will contain a large fraction of MOX rods (one-third or more), it is expected that the LA facility will need to receive LEU fuel assemblies (possibly, with unfilled rod positions) from a commercial fuel vendor. The LA fuel facility would then place MOX rods within the assembly and package the MOX LA for shipment to the reactor. Table 25 provides information on the shipment of LEU fuel assemblies to the MOX LA fuel facility, if needed.

\subsubsection{Fresh MOX Fuel Assemblies}

Table 26 provides information about the transport of fresh (unirradiated) MOX fuel from the fabrication facility to the commercial reactor, while Table 27 provides the fresh MOX fuel isotopic contents. The same package identified for shipment of the MOX fuel assemblies (the MO-1) would also be used to ship groups of individual MOX fuel rods to a commercial fuel fabrication site for insertion in a MOX fuel bundle if this approach is used.

\subsubsection{Spent MOX Fuel Assemblies}

Tables 28 and 29 provide information about the transport of spent (irradiated) MOX fuel from the commercial reactor to the PIE facility. Table 30 provides information regarding existing casks that could be used to transport spent MOX fuel to the PIE facility. The number of shipments of spent MOX fuel will depend on the actual plans for LA irradiation and plans for subsequent PIE. Based on the schedule described in Fig. 2, up to eight shipments of LA spent fuel could be transported between the reactor and the PIE facility. 
Table 23. Transportation of $\mathrm{PuO}_{2}$ to support $\mathrm{LA}$ fabrication

Number of shipments to LA fabrication site ${ }^{a}$

1 or more

Assuming $321 \mathrm{~kg} \mathrm{HM}$ of plutonium as $\mathrm{PuO}_{2}$ is needed for startup and to produce 10 LTAs

Would require about 73 packages $(4.4 \mathrm{~kg} \mathrm{HM} /$ package). SST could accommodate 30 to 35 packages per trailer. Sinģle SST convoy (three trailers) could deliver entire $\mathrm{PuO}_{2}$ supply for LTA campaign. To reduce facility inventory, could restrict each package to only $0.9 \mathrm{~kg}$. Thus, 357 packages would be needed, requiring four convoys of three SST; each

Container types used for shipments

Availability of containers

Likely candidate package would be 9968 or 9975 , perhaps SAFKEG

Only 9968 is currently certified

Average shipping container weight

Average material weight loaded into container

Average isotopic contents

Average exposure rate at $1 \mathrm{~m}$

Maximum anticipated dose rate at $1 \mathrm{~m}$

Type B

Yes

Will need to be determined

Regulatory limits are $200 \mathrm{mrem} / \mathrm{h}$ at surface of package $(1000 \mathrm{mrem} / \mathrm{h}$ for closed transport vehicles, exclusive use, sargo secured); $200 \mathrm{mrem} / \mathrm{h}$ (outer surface of vehicle); $10 \mathrm{mrem} / \mathrm{h}$ at point $2 \mathrm{~m}$ from package surface; and $2 \mathrm{mrem} / \mathrm{h}$ (in occupied spaces) (i.e., crew cab, etc.)

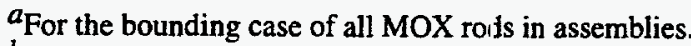

$b_{\text {See Chap. } 7 .}$

Table 24. Transportation of depleted $\mathrm{UO}_{2}$ to support $\mathrm{LA}$ fabrication ${ }^{a, b}$

\begin{tabular}{|c|c|}
\hline $\begin{array}{l}\text { Number of shipments to LA fabrication site } \\
\mathrm{UO}_{2} \text { is shipped in standard metal druns } \\
\text { Truck could accommodate } 40,000 \mathrm{lb}(-72 \text { drums }) \\
\text { Mission would only require about } 28 \text { clrums } \mathrm{UO}_{2}\end{array}$ & 1 \\
\hline $\begin{array}{l}\text { Container types used for shipments } \\
\text { A strong-tight container (open head 55-gal drum) } \\
\text { Probably use UN1A2 (steel drum) }\end{array}$ & 208-L drum \\
\hline Availability of containers & Yes \\
\hline Average shipping container weight, $\mathbf{k g}(\mathrm{lb})$ & $275 \mathrm{~kg}(600 \mathrm{lb})$ \\
\hline Average material weight loaded into container & $250 \mathrm{~kg}$ \\
\hline Average isotopic contents & Depleted uranium $a$ \\
\hline Average exposure rate at $1 \mathrm{~m}$ & -0 \\
\hline $\begin{array}{l}\text { Maximum anticipated dose rate at } 1 \mathrm{~m} \\
\text { Will need to be determined }\end{array}$ & $10 \mathrm{mrem} / \mathrm{h}$ \\
\hline $\begin{array}{l}\text { Regulatory limits are } 200 \mathrm{mrem} / \mathrm{h} \text { at surface of package }(1000 \mathrm{mrem} / \mathrm{h} \text { for } \\
\text { closed transport vehicles, exclusive use, cargo secured); } 200 \mathrm{mrem} / \mathrm{h} \\
\text { (outer surface of vehicle); } 10 \mathrm{mrem} / \mathrm{a} \text { at point } 2 \mathrm{~m} \text { from package surface; } \\
\text { and } 2 \mathrm{mrem} / \mathrm{h} \text { (in occupied spaces) (i.e., crew cab, etc.) }\end{array}$ & \\
\hline
\end{tabular}

$a_{\text {See Ref. }} 11$ for more information on depleted uranium. Refer to Table 27 for uranium isotopic content.

$b_{\text {Unlike }} \mathrm{UF}_{6}$ cylinders, depleted $\mathrm{UO}_{2}^{2}$, is purified, with daughter products removed that result in potential doses. 
Table 25. Transportation of materials to support LA fabrication (LEU fuel assemblies)

Number of shipments of LA fabrication site 1

Assuming that all $10 \mathrm{LEU}$ assemblies could be shipped on a single commercial vehicle (just as LEU fuel is shipped currently). Would require use of 5 LEU fuel packages.

Container types used for shipments

Availability of containers

Average shipping container weight, $\mathrm{kg}(\mathrm{lb})$

Average material weight loaded into container

Average isotopic contents

Average exposure rate at $1 \mathrm{~m}, \mathrm{mR} / \mathrm{h}$

Maximum anticipated dose rate at $1 \mathrm{~m}, \mathrm{mR} / \mathrm{h}$

Type AF

Yes

$2900 \mathrm{~kg}(6300 \mathrm{lb})$ to

$3800 \mathrm{~kg}(8400 \mathrm{lb})$

$1400 \mathrm{~kg}(3000 \mathrm{lb})$

LEU, up to $5 \%{ }^{235} \mathrm{U}$

$\sim$ (not measurable)

$10 \mathrm{mrem} / \mathrm{h}$

Will need to be determined

Regulatory limits are $200 \mathrm{mrem} / \mathrm{h}$ at surface of package $(1000 \mathrm{mrem} / \mathrm{h}$ for closed transport vehicles, exclusive use, cargo secured); $200 \mathrm{mrem} / \mathrm{h}$ (outer surface of vehicle); $10 \mathrm{mrem} / \mathrm{h}$ at point $2 \mathrm{~m}$ from package surface; and $2 \mathrm{mrem} / \mathrm{h}$ (in occupied spaces) (i.e., crew cab, etc.)

Table 26. Transportation of LAs to generic reactor site

Number of SST shipments of LAs to generic reactor

4

Assuming two shipments (four assemblies) each, to two different reactors, with two additional assemblies archived

Type of containers used for shipments

Likely candidate is the MO-1, USA/9069/B

Potential problems-NRC may require additional analysis to continue inclusion of MOX contents on package certificate. Also, MO-1 certificate lists 85\% fissile plutonium in total plutonium. WG MOX would be $-94 \%$, so additional analysis is needed to ensure that LTAs can be transported in MO-1 (may need to enhance criticality controls)

No package currently available in the United States for boiling-water reactor (BWR) MOX assemblies; probably could amend MO-1 certificate to allow two BWR assemblies

Availability of containers

Average shipping container weight

Gross weight, including two pressurized-water reactor (PWR) fuel assemblies

Average material weight loaded into shipping container

Average isotopic content (by isotope, mass \% content)

Average exposure rate at $1 \mathrm{~m}$

Will need to be determined, both for worker doses as well as transportation risk assessment

Should be fairly low

Maximum anticipated dose rate at $1 \mathrm{~m}$

Will need to be determined

Regulatory limits are $200 \mathrm{mrem} / \mathrm{h}$ at surface of package $(1000 \mathrm{mrem} / \mathrm{h}$ for closed transport vehicles, exclusive use, cargo secured); $200 \mathrm{mrem} / \mathrm{h}$ (outer surface of vehicle); $10 \mathrm{mrem} / \mathrm{h}$ at point $2 \mathrm{~m}$ from package surface; and $2 \mathrm{mrem} / \mathrm{h}$ (in occupied spaces) (i.e., crew cab, etc.)
Only two MO-1

packages exist

$3900 \mathrm{~kg}(8600 \mathrm{lb})$

$\sim 1400 \mathrm{~kg}(3000 \mathrm{lb})$

a

$0.1 \mathrm{mrem} / \mathrm{h}$

$10 \mathrm{mrem} / \mathrm{h}$

${ }^{a}$ See Table 27. 
Table 27. Fresh MOX fuel isotopic content ${ }^{a}$

\begin{tabular}{|c|c|}
\hline $\begin{array}{l}\text { Average isotopic content } \\
(\%)\end{array}$ & $\begin{array}{l}\text { Mass content } \\
(\%)\end{array}$ \\
\hline${ }^{235} \mathrm{U}, 0.2$ & 0.1915 \\
\hline${ }^{238} \mathrm{U}, 99.8$ & 95.556 \\
\hline${ }^{236} \mathrm{Pu},<1 \mathrm{ppb}$ & - \\
\hline${ }^{238} \mathrm{Pu}, 0.03$ & 0.00053 \\
\hline${ }^{239} \mathrm{Pu}, 92.44$ & 3.995 \\
\hline${ }^{240} \mathrm{Pu}, 6.47$ & 0.2485 \\
\hline${ }^{241} \mathrm{Pu}, 0.05$ & 0.00592 \\
\hline${ }^{242} \mathrm{Pu}, 0.1$ & 0.00249 \\
\hline${ }^{241} \mathrm{Am}, 0.9$ & 0.004 \\
\hline $\begin{array}{l}a_{S} \text { Source: Ref. } 10 . \\
\text { Note: MOX fuel wil } \\
\text { arious plutonium concen } \\
\text { n the mission reactors. }\end{array}$ & $\begin{array}{l}\text { oduced with } \\
s \text { depending }\end{array}$ \\
\hline
\end{tabular}

Table 28. Transportation of irradiated LAs to PIE site

\begin{tabular}{|c|c|}
\hline $\begin{array}{l}\text { Number of shipments of irradiated LAs to PIE site } \\
\text { Depending on cask selection, see Table } 30\end{array}$ & Up to 8 \\
\hline Types of container used for shipments & Type B \\
\hline Availability of shipping containers & Yes \\
\hline $\begin{array}{l}\text { Several available choices dependent on previous commitments, ability } \\
\text { of facilities to handle particular packages }\end{array}$ & \\
\hline $\begin{array}{l}\text { Possible choices-NAC-LWT or NLI. Each would hold one PWR or } \\
\text { two BWR assemblies }\end{array}$ & \\
\hline Average shipping container weight & $25-40$ tons \\
\hline Average material weight & $700-2100 \mathrm{~kg}(1500-4500 \mathrm{lb})$ \\
\hline Average isotopic content & See Table 29 \\
\hline $\begin{array}{l}\text { Uranium, transuranics, fission products (dependent on burnup and } \\
\text { decay time) }\end{array}$ & \\
\hline $\begin{array}{l}\text { Average exposure rate at } 1 \mathrm{~m}(\mathrm{mrem} / \mathrm{h}) \text { dependent on burnup and decay } \\
\text { time }\end{array}$ & $\sim 10 \mathrm{mrem} / \mathrm{h}^{a}$ \\
\hline $\begin{array}{l}\text { Maximum anticipated dose rate at } 1 \mathrm{~m} \\
\text { Dependent on fuel burnup and decay plusi selection of package } \\
\text { Must be below regulatory limits }\end{array}$ & Unknown \\
\hline
\end{tabular}

${ }^{a}$ Each cask will be loaded to the maximum capacity without exceeding regulatory dose limits. 
Table 29. Spent MOX fuel isotopic content

\begin{tabular}{|c|c|}
\hline Isotope & Mass content ${ }^{a}$ (g/assembly) \\
\hline \multicolumn{2}{|c|}{ Actinides } \\
\hline${ }^{234} U$ & $1.28 \times 10^{1}$ \\
\hline${ }^{235} \mathrm{U}$ & $3.56 \times 10^{2}$ \\
\hline${ }^{236} U$ & $1.13 \times 10^{2}$ \\
\hline${ }^{238} \mathrm{U}$ & $4.25 \times 10^{5}$ \\
\hline${ }^{237} \mathrm{~Np}$ & $8.42 \times 10^{1}$ \\
\hline${ }^{238} \mathrm{Pu}$ & $9.70 \times 10^{1}$ \\
\hline${ }^{239} \mathrm{Pu}$ & $6.99 \times 10^{3}$ \\
\hline $240 \mathrm{Pu}$ & $4.06 \times 10^{3}$ \\
\hline $241 \mathrm{Pu}$ & $1.49 \times 10^{3}$ \\
\hline $242 \mathrm{Pu}$ & $7.50 \times 10^{2}$ \\
\hline${ }^{241} \mathrm{Am}$ & $1.04 \times 10^{3}$ \\
\hline $242 \mathrm{Am}$ & $3.22 \times 10^{0}$ \\
\hline $243 \mathrm{Am}$ & $2.03 \times 10^{2}$ \\
\hline${ }^{242} \mathrm{Cm}$ & $8.39 \times 10^{-3}$ \\
\hline${ }^{243} \mathrm{Cm}$ & $8.73 \times 10^{-1}$ \\
\hline${ }^{244} \mathrm{Cm}$ & $5.38 \times 10^{1}$ \\
\hline${ }^{245} \mathrm{Cm}$ & $5.40 \times 10^{0}$ \\
\hline \multicolumn{2}{|c|}{ Fission products } \\
\hline${ }^{90} \mathrm{Sr}$ & $1.31 \times 10^{2}$ \\
\hline${ }^{106} \mathrm{Ru}$ & $1.77 \times 10^{-1}$ \\
\hline${ }^{126} \mathrm{Sn}$ & $2.22 \times 10^{1}$ \\
\hline${ }^{126} \mathrm{Sb}$ & $1.06 \times 10^{-6}$ \\
\hline${ }^{134} \mathrm{Cs}$ & $2.81 \times 10^{0}$ \\
\hline${ }^{137} \mathrm{Cs}$ & $6.21 \times 10^{2}$ \\
\hline${ }^{144} \mathrm{Ce}$ & $2.21 \times 10^{-2}$ \\
\hline${ }^{147} \mathrm{Pm}$ & $6.71 \times 10^{0}$ \\
\hline $148 \mathrm{Nd}$ & $2.25 \times 10^{2}$ \\
\hline${ }^{154} \mathrm{Eu}$ & $1.30 \times 10^{1}$ \\
\hline
\end{tabular}

${ }^{a}$ Spent fuel composition is for MOX containing $4.56 \mathrm{wt} \%$ plutonium at a burnup of $45 \mathrm{GWd} / \mathrm{MT}, 10$ years after discharge. Table includes only most significant isotopes.

Source: Memorandum, B. D. Murphy to R. T. Primm III, "Computational Support to Yucca Mountain Project Environmental Impact Statement Data Call," September 12, 1997. 
Table 30. Examples of casks for LWR spent fuel

\begin{tabular}{|c|c|c|c|c|c|}
\hline Name & Owner & Certification No. & $\begin{array}{l}\text { Gross } \\
\text { weight } \\
\text { (lb) }\end{array}$ & Cavity size & Contents \\
\hline NAC-LWT & $\begin{array}{l}\text { NAC } \\
\text { International, } \\
\text { Norcross, GA }\end{array}$ & USA $9225 / B(U) F$ & 51,200 & $\begin{array}{l}\text { 181-in. long by } 13.4 \text {-in. } \\
\text { diam }\end{array}$ & $\begin{array}{l}1 \text { PWR or } 2 \\
\text { BWR } \\
\text { assemblies }\end{array}$ \\
\hline NLI-1/2 & $\begin{array}{l}\text { NAC } \\
\text { International, } \\
\text { Norcross, GA }\end{array}$ & USA/ $: 010 / B() F$ & 49,250 & $\begin{array}{l}\text { 178-in. long by } 13.4 \text {-in. } \\
\text { diam }\end{array}$ & $\begin{array}{l}1 \text { PWR or } 2 \\
\text { BWR } \\
\text { assemblies }\end{array}$ \\
\hline TN-8L & $\begin{array}{l}\text { Transnuclear, } \\
\text { Hawthorne, NY }\end{array}$ & USA $/ 015 / B() F$ & 79,380 & $\begin{array}{l}3 \text { cavities, } \\
9 \text { in. } \times 9 \text { in } \times 168.5 \text { in. }\end{array}$ & $\begin{array}{l}3 \text { PWR } \\
\text { assemblies }\end{array}$ \\
\hline TN-9 & $\begin{array}{l}\text { Transnuclear, } \\
\text { Hawthorne, NY }\end{array}$ & USA/S1016/B( )F & 79,200 & $\begin{array}{l}7 \text { cavities, } \\
-6 \text { in. } \times 6 \text { in. } \times 178 \text { in. }\end{array}$ & $\begin{array}{l}7 \text { BWR } \\
\text { assemblies }\end{array}$ \\
\hline
\end{tabular}




\section{QUALITATIVE DECONTAMINATION AND DECOMMISSIONING DISCUSSION}

\subsection{INTRODUCTION}

The DOE facilities that will be used in the fabrication of MOX LAs have been used previously in the handling of nuclear materials. Because most of the facilities are contaminated to some degree, the MOX mission should have few incremental effects on the ultimate D\&D of these facilities. The intent of the FMDP is to decontaminate the facilities to levels that would permit unrestrictive further use of the facilities.

\subsection{PROCESS PLAN}

The development of a detailed D\&D plan will be necessary to minimize waste generation. Waste minimization during D\&D begins with the design of the MOX facility as discussed below. During the D\&D phase, waste minimization measures would be similar to those required in the operation of any nuclear contamination zone. This includes reducing the number of items taken into a contamination zone to the minimum necessary to perform the job.

\subsection{D\&D OPERATIONS}

Because plutonium is primarily an alpha emitter, containment of contamination is a principle concern in the design and operation of a MOX plant. The process involves two distinctly different areas concerning contamination: (1) pellet fabrication where dusty powders of plutonium and uranium oxides are handled and (2) the rod and bundle assembly areas where little if any contamination should be present. At least $95 \%$ of the waste that will be generated during D\&D will be from the pellet fabrication area.

In the pellet fabrication area, a principle concern must be containment of the potential contamination from the copious quantities of plutonium and uranium dust that will be generated during operation of the dry processes. To minimize future D\&D costs, the containment of this potential contamination at its source of generation must be considered in the design of the MOX facility. This design should include local filtration at the source with no contamination allowed in the duct systems.

The rod and bundle assembly areas will use about $50 \%$ of the total space in the MOX facility and should be relatively contamination free. This space could be returned to beneficial occupancy soon after completion of the mission by simply removing the process equipment. Most of the uncontaminated rod and bundle assembly equipment will likely be useful in the full-scale MOX plant and could be shipped to that facility in the future.

Most of the waste generated during D\&D will come from the pellet fabrication area in the disassembly and disposal of contaminated process equipment items and excess glove boxes. The waste generated during $D \& D$, in addition to the contaminated equipment items and glove boxes, will be similar to the waste generated during operation of the MOX plant. This will consist of solid and liquid radioactive waste in similar types and volumes that will be generated during operations. The ratio of TRU to LLW likely will be higher during D\&D from the cleanup of the plutonium contamination in the glove boxes. The emissions during D\&D should be no more than during the operating phase of the LA MOX plant.

Complete decontamination probably will not be possible for most of the glove boxes and contaminated equipment items, and disposal as either LLW or TRU waste will be required. Most of the large equipment items and excess glove boxes likely will be packaged in large B-25 ( $4 \mathrm{ft} \times 4 \mathrm{ft} \times 6 \mathrm{ft})$ metal waste boxes. Size reduction of some equipment items and glove boxes likely will be required to fit within these boxes. The assay of the TRU content in some contaminated equipment items will be difficult to determine because of the difficulty of establishing calibration standards for the assay equipment. Also, the waste acceptance criteria for such "difficult to certify" TRU waste items for WIPP disposal have not been completely resolved by $\mathrm{DOE}$. 
The equipment in the rod and bundle assembly areas either will not be contaminated or probably can be decontaminated to clean release standards for unrestricted use. The disposal of this equipment should present no particular problem. 


\section{PIE}

The two sites being considered for the PIE are Argonne National Laboratory-West (ANL-W) and ORNL. The facilities and infrastructure required to complete all PIE activities for the LA program currently exist at both sites. Accommodation of full-length fuel rods is the only modification required at ANL-W or ORNL to process the materials associated with this program. Both sites currently process equivalent materials to those expected in this program, and program activities will be routine.

Table 31 shows the wastes estimated during the LA PIE. Table 32 shows the possible employee radiation doses involved during PIEs of the LAs, and Table 33 lists the estimated PIEs for the EIS.

Figure 12 shows the location of Building 3525 on the ORNL site, and Fig. 13 shows the location of Building 785 on the ANL-W site. These buildings could be used to perform all PIE activities.

\subsection{PIE DISCUSSION}

PIE begins by shipping either the fuel assembly or the individual rods to the PIE facility. Shipment of selected individual rods is desired as it eliminates a handling step at the PIE facility (disassembly of the fuel assembly) and reduces the amount of irradiated fuel that needs to be handled (because only a fraction of the rods in a bundle is examined), stored, and disposed of at the hot cell.

Once the rods are in the hot cell at the PIE facility they are first subjected to a nondestructive examination. The degree of examination varies, but typically the rods are visually examined for signs of damage or wear, their length and diameter is measured, and individual rods may be weighed. After this simple check, additional examinations include eddy current or ultrasonic testing to locate cracks or flaws; leak testing to determine gas containment; gamma scanning to determine the internal fuel rod integrity, migration of fission products, and burnup; neutron radiography and X-ray radiography to determine the internal physical configuration; and detailed visual examination of any crud or oxide layers on the surface of the clad. The particular techniques employed will depend on the program needs.

After the nondestructive testing has been satisfied, the destructive testing often begins by sampling the fission gas pressure and composition in the rod plenum by puncturing the end of the rod and collecting the gas. The rod may then be cut into segments for fuel examination. Thin sections of the rod are often cut off, mounted in epoxy resin, and polished for metallographic and ceramographic examinations. Additional portions of the fuel rod may be cut up for further fuel and clad examinations. Thin cross sections of the rod may be core drilled for fuel samples and the cores examined by gamma scanning or subjected to radiochemistry examination by dissolution in a chemical solution. The solution may undergo chemical analysis, gamma counting, and/or mass spectrometry for the determination of burnup and fission product composition.

Fuel specimens may undergo density measurements, pore size measurements, thermal diffusivity measurements, specific heat determination, melting point temperature estimation, oxygen to metal ratio measurements, and/or fission gas diffusivity depending on the degree of the investigation and the equipment available.

The rod cross sections may also be mounted in special mounts for examination by microprobe, optical microscope, transmission electron microscopy, and/or scanning electron microscope. Other techniques such as X-ray fluorescence and emission spectroscopy may be used depending on the needs of the investigation. These techniques allow the experimenter to determine the amounts and distribution of fission products, plutonium, uranium, and some trace elements. Such analyses allow the experimenter to compare the results of the irradiation with predictions and to investigate fuel behavior in considerable detail.

Clad specimens for mechanical testing may be prepared by segmenting the fuel rod and sliding the fuel out if possible, drilling the fuel out, or cutting and peeling the clad from the fuel. Once prepared, the clad may be subjected to a wide variety of tests such as tensile testing, burst testing, hardness testing, ductility testing, creep tests, fatigue testing, and chemical surface analysis.

All of these tests are considered to be normal PIE practices. The scope of the required equipment can be as simple as a small numbered scale to complex expensive shielded special purpose microscopes. Two references for PIE work are the Guidebook on Non-Destructive Examination of Water Reactor Fuel, IAEA 
Table 31. Estimated waste generated during the LA PIE

\begin{tabular}{|c|c|c|c|c|}
\hline Waste category & Annual volume & $\begin{array}{l}\text { Total estimated volume } \\
\text { (based on } 4 \text { years) }\end{array}$ & $\begin{array}{l}\text { Waste description } \\
\text { (e.g., glove box gloves, cleaning } \\
\text { solvent, paper wipes) }\end{array}$ & $\begin{array}{l}\text { Anticipated treatment and/or } \\
\text { disposal method } \\
\text { (e.g., solidification) } \\
\text { (specify on-site or off-site) }\end{array}$ \\
\hline $\begin{array}{l}\text { TRU } \\
\text { Liquid } \\
\text { Solid }\end{array}$ & $\begin{array}{l}107 \mathrm{~L}(28.2 \mathrm{gal}) \\
2.6 \mathrm{~m}^{3}\left(91.8 \mathrm{ft}^{3}\right)\end{array}$ & $\begin{array}{l}427 \mathrm{~L}(112.8 \mathrm{gal}) \\
10.4 \mathrm{~m}^{3}\left(367.3 \mathrm{ft}^{3}\right)\end{array}$ & $\begin{array}{l}\text { Paper wipes, plastic, glassware, metal } \\
\text { containers, fuel debris, clad pieces, } \\
\text { radiochemical solutions }\end{array}$ & $\begin{array}{l}\text { Solid material packaged in drums } \\
\text { for shipment to WIPP; liquids } \\
\text { processed on-site for later off-site } \\
\text { disposal as LLW }\end{array}$ \\
\hline $\begin{array}{l}\text { Mixed TRU } \\
\text { Liquid } \\
\text { Solid }\end{array}$ & $\begin{array}{l}1.08 \mathrm{~L}(0.29 \mathrm{gal}) \\
0.03 \mathrm{~m}^{3}\left(0.883 \mathrm{ft}^{3}\right)\end{array}$ & $\begin{array}{l}4.3 \mathrm{~L}(1.16 \mathrm{gal}) \\
0.1 \mathrm{~m}^{3}\left(3.53 \mathrm{ft}^{3}\right)\end{array}$ & $\begin{array}{l}\text { Oils, solvents, and lead shielding con- } \\
\text { taminated with TRU materials. }\end{array}$ & $\begin{array}{l}\text { Solid material will be packaged in } \\
\text { drums for shipment to WIPP; liq- } \\
\text { uids will be processed on site for } \\
\text { later off-site disposal as LLW }\end{array}$ \\
\hline $\begin{array}{l}\text { LLW }^{a} \\
\text { Liquid } \\
\text { Solid }\end{array}$ & $\begin{array}{l}107 \mathrm{~L}(28.2 \mathrm{gal}) \\
35 \mathrm{~m}^{3}\left(1236 \mathrm{ft}^{3}\right)\end{array}$ & $\begin{array}{l}427 \mathrm{~L}(112.8 \mathrm{gal}) \\
140 \mathrm{~m}^{3}\left(4944 \mathrm{ft}^{3}\right)\end{array}$ & $\begin{array}{l}\text { Paper wipes, plastic, glassware, metal } \\
\text { containers, clad pieces, equipment }\end{array}$ & $\begin{array}{l}\text { Material will be prepared on-site } \\
\text { for shipment to off-site facility }\end{array}$ \\
\hline $\begin{array}{l}\text { Mixed LLW } \\
\text { Liquid } \\
\text { Solid }\end{array}$ & $\begin{array}{l}1.08 \mathrm{~L}(0.29 \mathrm{gal}) \\
0.35 \mathrm{~m}^{3}\left(12.36 \mathrm{ft}^{3}\right)\end{array}$ & $\begin{array}{l}4.3 \mathrm{~L}(1.16 \mathrm{gal}) \\
1.4 \mathrm{~m}^{3}\left(49.4 \mathrm{ft}^{3}\right)\end{array}$ & $\begin{array}{l}\text { Oils, solvents, and lead shielding con- } \\
\text { taminated with fission products } \\
\text { materials }\end{array}$ & $\begin{array}{l}\text { Material will be sorted and pre- } \\
\text { pared on-site for shipment to off- } \\
\text { site facilities }\end{array}$ \\
\hline $\begin{array}{l}\text { Hazardous } c \\
\text { Liquid } \\
\text { Solid }\end{array}$ & $\begin{array}{l}1.08 \mathrm{~L}(0.29 \mathrm{gal}) \\
0.35 \mathrm{~m}^{3}\left(12.36 \mathrm{ft}^{3}\right)\end{array}$ & $\begin{array}{l}4.3 \mathrm{~L}(1.16 \mathrm{gal}) \\
1.4 \mathrm{~m}^{3}\left(49.4 \mathrm{ft}^{3}\right)\end{array}$ & $\begin{array}{l}\text { Used oils, solvents, resins, glues, } \\
\text { containers }\end{array}$ & $\begin{array}{l}\text { Material will be sorted and pre- } \\
\text { pared on-site for shipment to off- } \\
\text { site facilities }\end{array}$ \\
\hline $\begin{array}{l}\text { Nonhazardous (sanitary) } \\
\text { Liquid } \\
\text { Solid }\end{array}$ & $\begin{array}{l}3.79 \times 10^{5} \mathrm{~L}\left(1.0 \times 10^{5} \mathrm{gal}\right) \\
50 \mathrm{~m}^{3}\left(1765 \mathrm{ft}^{3}\right)\end{array}$ & $\begin{array}{l}1.51 \times 10^{6} \mathrm{~L}\left(4 \times 10^{5} \mathrm{gal}\right) \\
130 \mathrm{~m}^{3}\left(4591 \mathrm{ft}^{3}\right)\end{array}$ & $\begin{array}{l}\text { Potable water, cleaning, paper, plastic, } \\
\text { metal containers, garbage }\end{array}$ & $\begin{array}{l}\text { Materials will be disposed of } \\
\text { through laboratory (on-site) non- } \\
\text { hazardous waste facility }\end{array}$ \\
\hline $\begin{array}{l}\text { Nonhazardous (other) } \\
\text { specific by waste } \\
\text { Liquid } \\
\text { Solid }\end{array}$ & $\begin{array}{l}4 \mathrm{~L}(1.06 \mathrm{gal}) \\
0.75 \mathrm{~m}^{3}\left(26.48 \mathrm{ft}^{3}\right)\end{array}$ & $\begin{array}{l}16 \mathrm{~L}(4.23 \mathrm{gal}) \\
3 \mathrm{~m}^{3}\left(106 \mathrm{ft}^{3}\right)\end{array}$ & $\begin{array}{l}\text { Chemical reagents, oils, cleaners, scrap } \\
\text { metal, wood, plastic }\end{array}$ & $\begin{array}{l}\text { Materials will be disposed through } \\
\text { laboratory (on-site) nonhazardous } \\
\text { waste facility. Scrap may be dis- } \\
\text { posed of through the laboratory to } \\
\text { off-site vendors }\end{array}$ \\
\hline
\end{tabular}

Note: Estimates are based on historical experience from other programs and current operations. The actual waste stream will be strongly dependent on the type and amount of work performed. The actual waste handling will depend on the laboratory facilities in operation at the time and the current disposal regulations. The final volumes of waste will be smaller depending on the treatment option (drying, compacting, burning).

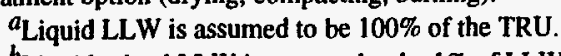

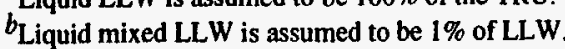

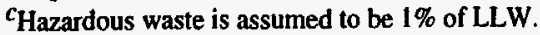


Table 32. Radiation doses to involved workers during the LA PIE (whole body CEDE)

\begin{tabular}{lr}
\hline Average annual dose to all involved workers at the facility, mrem & 177 \\
Maximum dose to an involved worker at the facility, mrem & 347 \\
Total number of involved workers & 10 \\
\hline
\end{tabular}

Note: Table numbers are averages over 1994, 1995, and 1996 for Building 3525 at ORNL. Values are from the radiation protection representative. It is assumed that the MOX PIE will encounter similar exposures.

Table 33. PIE estimates for EIS

\begin{tabular}{|c|c|c|}
\hline \multicolumn{2}{|l|}{ For planning purposes assume 17 by 17 fuel bundle array } & 289 rods total \\
\hline \multicolumn{2}{|l|}{ Bundle length } & $13.50 \mathrm{ft}$ \\
\hline \multicolumn{2}{|l|}{ Pellet size } & $\begin{array}{l}0.37 \text {-in. diam, } \\
0.60 \text {-in. length, and } \\
0.06 \text {-in. }{ }^{3} \text { volume }\end{array}$ \\
\hline \multicolumn{2}{|l|}{ Approximate density $\mathrm{UO}_{2}+\mathrm{PuO}_{2}$} & $11.00 \mathrm{~g} / \mathrm{cm}^{3}$ \\
\hline \multicolumn{2}{|l|}{ Mass of pellet } & $11.43 \mathrm{~g}$ \\
\hline \multicolumn{2}{|l|}{ Mass of pellet $\mathrm{HM}$} & $10.08 \mathrm{~g}$ \\
\hline \multicolumn{2}{|l|}{ Pellets per rod } & 270.00 \\
\hline \multicolumn{2}{|l|}{ Pellet mass per rod } & $3087 \mathrm{~g}$ \\
\hline \multicolumn{2}{|l|}{ HM per rod } & $2721 \mathrm{~g}$ \\
\hline \multicolumn{2}{|l|}{$\begin{array}{l}\text { Assume detailed PIE will involve ten rods per bundle and } \\
\text { ten bundles }\end{array}$} & 100 rods to be cut up \\
\hline \multicolumn{2}{|l|}{ Estimated samples per rod } & 10 \\
\hline \multicolumn{2}{|l|}{ Total samples } & 1000 \\
\hline \multicolumn{2}{|l|}{ Assume one-third metal mounts } & 333 \\
\hline \multicolumn{2}{|l|}{ Assume one-third clad specimens } & 333 \\
\hline \multicolumn{2}{|l|}{ Assume one-third radiochemical specimens } & 333 \\
\hline Liquid waste per metal mount & $0.5 \mathrm{~L}$ & $\begin{array}{l}167 \mathrm{~L} \text { total for } \\
\text { metal mounts }\end{array}$ \\
\hline Liquid waste per clad specimen & $0.1 \mathrm{~L}$ & $\begin{array}{l}33 \mathrm{~L} \text { total for } \\
\text { clad specimen }\end{array}$ \\
\hline Liquid waste per radiochemical specimens & $1 \mathrm{~L}$ & $\begin{array}{l}33 \mathrm{~L} \text { total for } \\
\text { radiochemical }\end{array}$ \\
\hline Total specimen liquid waste (TRU) & & $533 \mathrm{~L}$ \\
\hline Solid waste per metal mount and all mounts & $200 \mathrm{~cm}^{3}$ & $0.07 \mathrm{~m}^{3}$ total \\
\hline Solid waste per clad specimen and all clad specimens & $200 \mathrm{~cm}^{3}$ & $0.07 \mathrm{~m}^{3}$ total \\
\hline Solid waste per radiochemical specimen and all specimens & $500 \mathrm{~cm}^{3}$ & $0.17 \mathrm{~m}^{3}$ total \\
\hline Total specimen solid waste (TRU) & & $0.30 \mathrm{~m}^{3}$ \\
\hline Assume two $\mathrm{B}-25$ boxes of equipment & & $6 \mathrm{~m}^{3}$ \\
\hline One-half equipment LLW & & $3 \mathrm{~m}^{3}$ \\
\hline One-half equipment TRU & & $3 \mathrm{~m}^{3}$ \\
\hline Assume one B- 25 box per month $/ 48$ months & & $144 \mathrm{~m}^{3}$ \\
\hline $\begin{array}{l}0.9 \text { LLW [personal protective equipment (PPE), wipes, } \\
\text { scrap, etc.] }\end{array}$ & & $130 \mathrm{~m}^{3}$ \\
\hline 0.1 TRU & & $14 \mathrm{~m}^{3}$ \\
\hline Total liquid TRU waste & & $533 \mathrm{~L}$ \\
\hline Total solid TRU waste & & $18 \mathrm{~m}^{3}$ \\
\hline
\end{tabular}


Table 33. (continued)

Total mixed liquid TRU waste

Total mixed solid TRU waste

Total liquid LLW

Total solid LLW

Total mixed liquid LLW

Total mixed solid LLW

Other waste streams

Liquid hazardous waste

Solid hazardous waste

Nonhazardous liquid waste

Nonhazardous solid waste

Nonhazardous liquid other waste-chernicals

Nonhazardous solid other waste-scrap metal, one B-25 box
$5 \mathrm{~L}$ (estimated as $1 \%$ of TRU)

$0.18 \mathrm{~m}^{3}$ (estimated as $1 \%$ of TRU)

$533 \mathrm{~L}$ (estimated same as TRU)

$133 \mathrm{~m}^{3}$

$5 \mathrm{~L}$ (estimated as $1 \%$ of LLW)

$1 \mathrm{~m}^{3}$ (estimated as $1 \%$ of LLW)

$5 \mathrm{~L}$ (estimated as $1 \%$ of LLW)

$1 \mathrm{~m}^{3}$ (estimated as $1 \%$ of LLW)

$533 \mathrm{~L}$ (estimated as $100 \%$ LLW)

$133 \mathrm{~m}^{3}$ (estimated as $100 \%$ of LLW)

$5 \mathrm{~L}$ (estimated as $1 \%$ of LLW)

$3 \mathrm{~m}^{3}$

Assume that bulk of the fuel rods and fuel bundle will be handled as spent nuclear fuel and sent to Idaho National Engineering and Environmental Laboratory 


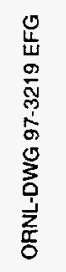

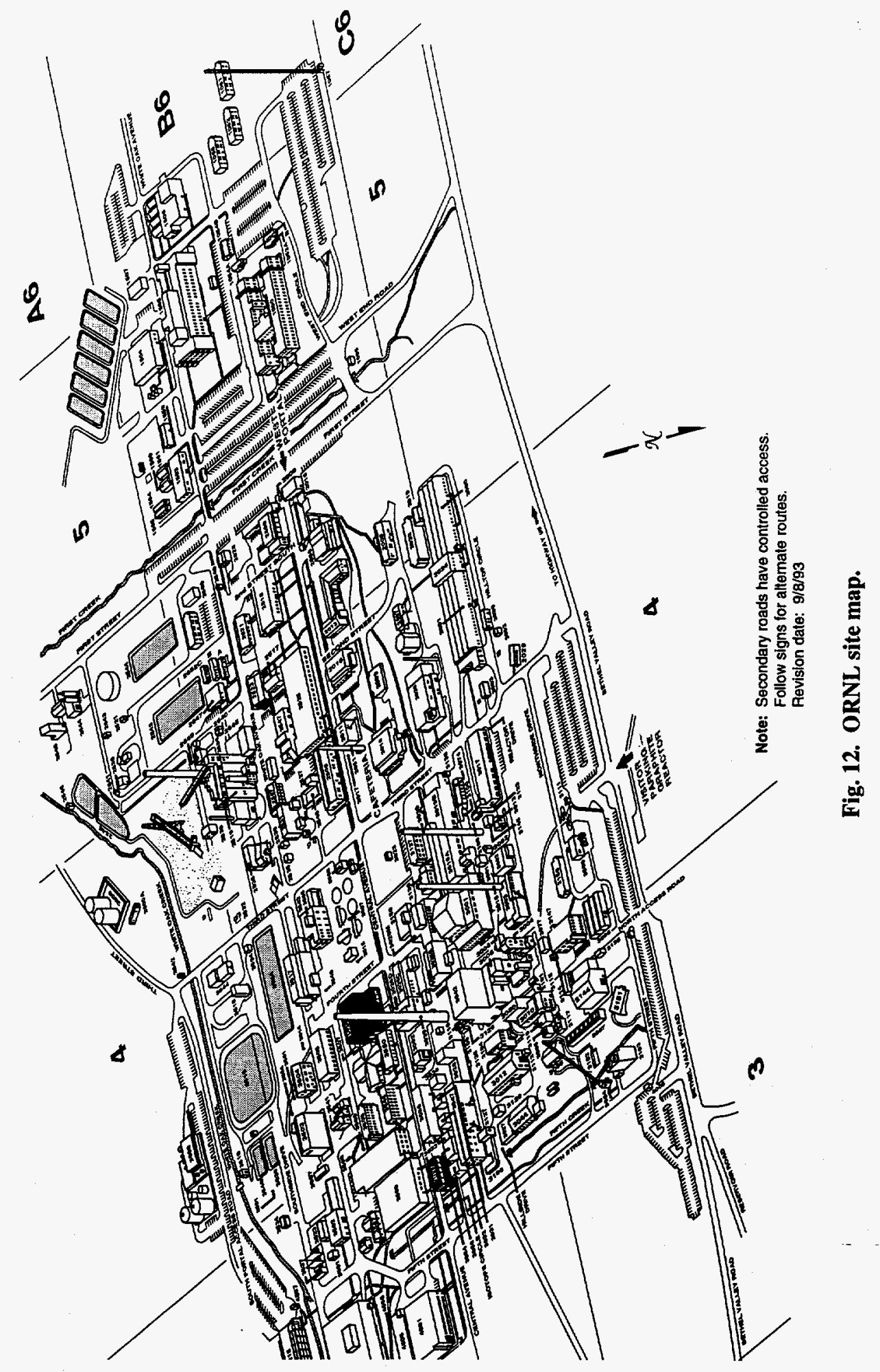


704 Fuel Manufacluring Facility (FMF)

752 Laboratory And Office Buikding (L\&O Building)

77. Radioactive Scrap And Wasto Facility (RSWF

75 ZPPR Workroom-Equipment Room

776 ZPPP Reactor Cell

785 Hot Fuel Examination Facility (HFEF)

797 Radioactive Sodium Storage Facility (RSSF)

798 Radioactive Liquid Waste Treatment Facility (RLWTF)

771 Shown Out Of Position

And At One-Hali Scale

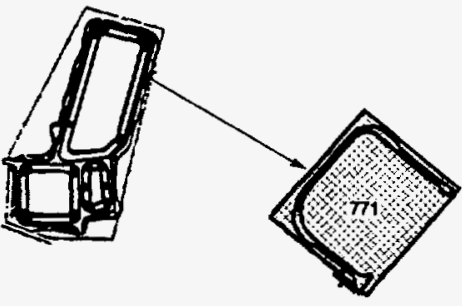

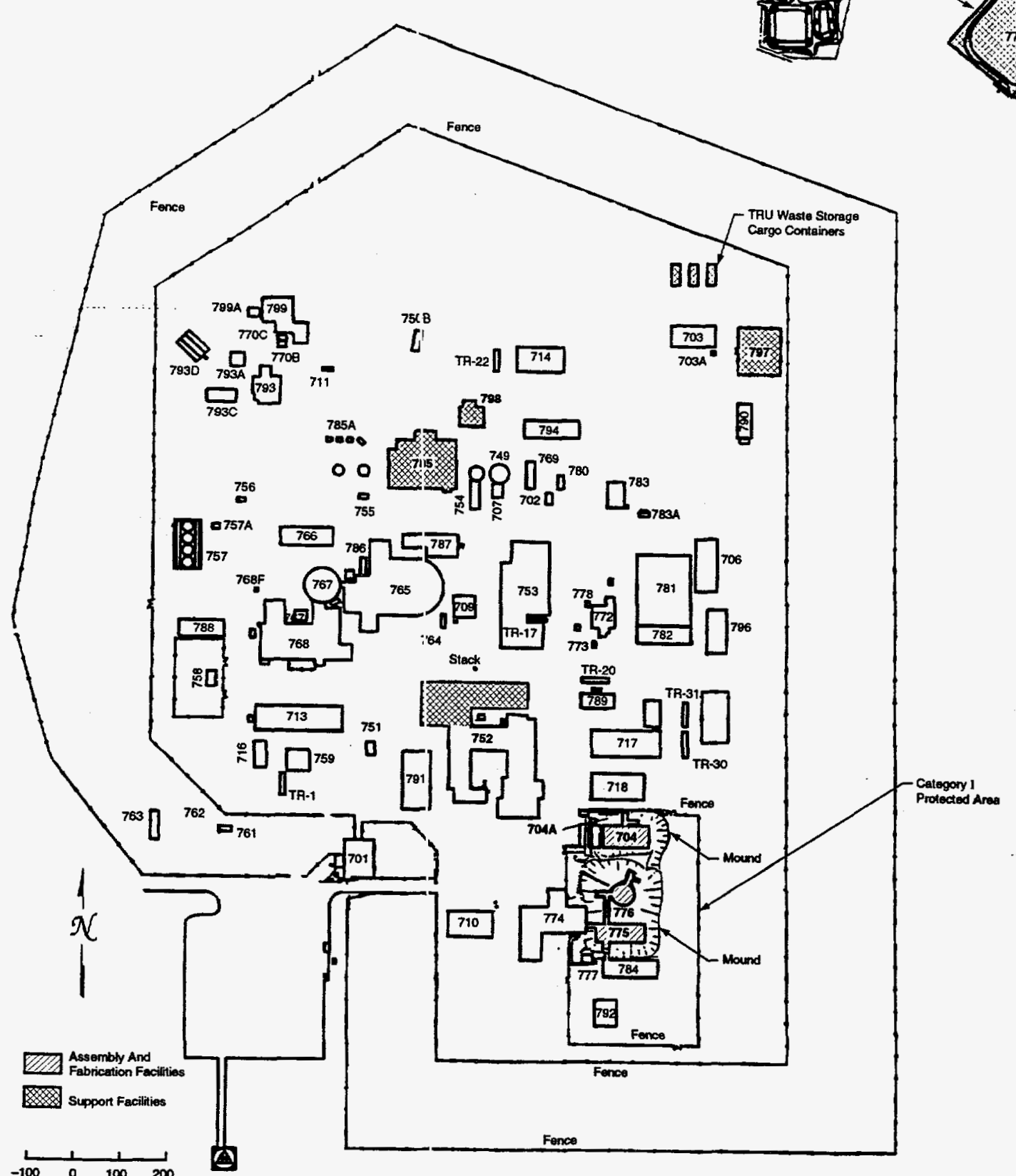

Fig. 13. ANL-W site map. 
Technical Reports Series No. 322; and the Guidebook on Destructive Examination of Water Reactor Fuel, IAEA Technical Reports Series No. 385.

In addition to materials testing, the segmented fuel may be used as a test subject for accident testing. The segment may be heated to high temperatures in a variety of atmospheres in a complex test apparatus and its releases measured. Other specialized methods also exist; irradiated material may be removed from one experiment and transferred to another in the hot cell for further irradiation.

The fuel rods in the MOX program will employ nondestructive examination as well as many of the destructive techniques. Normal practice is rather broad, and the actual techniques and items of interest will be determined before PIE and will depend on the program's knowledge and confidence level at the time.

\subsection{ANL-W}

The Hot Fuel Examination Facility (HFEF) is a hot-cell complex for the preparation and examination of irradiated experiments and the characterization and testing of waste forms from conditioning of spent fuel and waste. The HFEF is located on the ANL-W site, which is located in the south-west corner of INEEL. The HFEF facility is located on the north end of a double-fenced compound on the ANL-W site.

HFEF consists of two adjacent shielded hot cells (the main and decon cells), a shielded metallographic loading box, an unshielded Hot Repair Area (HRA) and a Waste Characterization Area (WCA). The building is a three-story structure with a basement support area. The building dimensions are $112 \mathrm{ft}$ wide by $154 \mathrm{ft}$ long with a gross floor area of $56,570 \mathrm{ft}^{2}$ and a gross volume of $1,337,200 \mathrm{ft}^{3}$.

The metallographic loading box is located outside the main cell in the metallograph room. This room is located on the north side of the building on the main floor and is separated from the main cell by an operating corridor.

The HRA and WCA are located in the high bay area. The area provides access to the ceiling penetrations in the main and decon cells as well as the HRA roof hatch. The high bay is also used as a staging area for the WCA.

Since the shutdown and defueling of the EBR-II reactor, HFEF has been used for many diverse programs. The primary program, since October 1994, has been the support of the EBR-II defueling and decommissioning. HFEF was responsible for receiving all of the fuel and blanket material from EBR-II and preparing the material for storage in the Radioactive Scrap and Waste Facility (RSWF).

In addition to the handling of the EBR-II fuel, HFEF is the examination facility for both the metal and ceramic waste form experiments from FCF. Cladding hulls from the conditioning of fuel in FCF need to be processed for disposal in a repository. The processing of the cladding hulls and the characterization of the waste form is being tested in HFEF. In addition, equipment is being installed and processes tested for the disposal of the plutonium and fission product waste from the conditioning of EBR-II fuel. The testing and characterization of the ceramic waste forms will be performed in HFEF.

HFEF is presently starting facility modification to accept commercial-sized fuel assemblies from the Watts Bar reactor. These assemblies (specifically, tritium production burnable absorber rods) are the initial assemblies being irradiated as part of DOE's commercial LWR tritium production evaluation. All of the examination equipment in the cell and the cask handling systems are being modified to handle commercialsized casks and fuel rods for examination. These modifications will be complete in mid-1999.

Some of the stainless steel reflector subassemblies used in EBR-II have experienced neutron exposure since the reactor was started in the early 1960s. The neutron damage to these steels is of interest to the commercial power industry, especially in Japan. Two programs are in place where the stainless steels are being prepared for testing of the neutron damage. These programs involve the cutting and preparation of samples for testing at other laboratories.

The north neutron radiography station has been modified to house a neutron generator for neutron assay of waste. Testing is presently being done on developing neutron assay techniques for the waste from the FCF.

In support of the National Spent Fuel Program, HFEF is presently engaged in the examination of degraded EBR-II fuels that have been stored in water pools at the ICPP. The fuel was shipped to ICPP in sealed containers. During the 15 to 20 years of storage in the water basin at ICPP, some of the containers 
have leaked, causing the fuel to breach. The characterization and examination of the degraded fuel at the HFEF will determine the chemical condition of the fuel as well as the mechanism for breaching. This program will be ongoing during the next 2 years.

\subsubsection{Main Cell}

The HFEF main cell is $70 \mathrm{ft}$ long by $30 \mathrm{ft}$ wide by $25 \mathrm{ft}$ high and has an argon gas atmosphere. The argon gas in the cell is maintained as pure as possible; however, a small amount of moisture is needed to help lubricate and cool the brushes on the electric motors used in cell. Because of this, the moisture and oxygen levels are maintained about $40 \mathrm{pl} \mathrm{m}$. The maximum oxygen and moisture levels are kept below 100 $\mathrm{ppm}$. The cell atmosphere is maintained at these levels using a purification system.

An 8-ft deep space that is located beneath removable flooring and covers the entire width of the cell is used for storage of fuel elements during their examination. Also located in this space are the bases of the examination stages, ducts and filters for the main cell cooling system, and pits for the storage of radioactive materials. A total of ten 1-ft diam by $10 \mathrm{ft}$ long storage pipes are located in the center aisle of the cell for storage of Experimental Breeder Reactor-II (EBR-II) subassemblies. These pits are equipped with forced argon cooling for decay heat removal of their contents.

In addition to the subfloor space, two $3-\mathrm{ft}$ diam pits extend $30 \mathrm{ft}$ below the level of the removable floor at workstations $8 \mathrm{M}$ and $9 \mathrm{M}$ (soulh-east corner of the cell). These pits are used for storing and handling of long items such as long test loops. Each pit has a corresponding roof penetration so long items can be transferred into the cell and placed in a pit.

The main cell is serviced by two electro-mechanical manipulators (EMMs) rated for $750 \mathrm{lb}$ and two 5-ton bridge cranes. The maximum lift for an EMM in the main cell is $11 \mathrm{ft} 8 \mathrm{in}$. The maximum lift for a crane in the cell is $19 \mathrm{ft} 11-5 / 8$ in.

There are 15 workstations in the main cell. Each workstation is equipped with two master/slave (MS) manipulators. Most of the MS manipulators are Central Research Laboratory (CRL) Model J's rated for a 20-1b vertical lift. Five of the workstatic ns are equipped with CRL System 50 manipulators rated for a 50-lb vertical lift.

\subsubsection{Decon Cell}

The air-filled decon cell is located adjacent to the west end of the main cell and is $30 \mathrm{ft}$ wide by $20 \mathrm{ft}$ long by $25 \mathrm{ft}$ high. There is no subfloor space in the decon cell; however, three 15.5-in. diam by 10-ft deep pits are located at workstation 3D. Another similar pit is located at workstation $4 \mathrm{D}$, and a $3-\mathrm{ft}$ diam by 30 -ft deep pit is located at workstation 5D.

The decon cell is equipped with an 8 -ft wide by 7 - $\mathrm{ft}$ deep by $11-\mathrm{ft}$ high spray chamber for decontaminating equipment and nonfissile material using a manipulator-held wand. The wand can be used for spraying either water or steam. A chemical addition tank is connected to the water feed line for the addition of decontamination solutions to the water stream. Items being decontaminated are positioned on a 5-ton turntable inside the chamber so that they can be rotated. Both the roof and back side of the spray chamber can be opened remotely so items being decontaminated can be placed inside the chamber.

Material handling inside the decon cell is performed with one 750-1b EMM and one 5-ton crane. The maximum lifting height of the EMM is $11 \mathrm{ft} 8 \mathrm{in}$. and that of the crane is $19 \mathrm{ft} 11 \mathrm{in}$. In addition to the EMM and crane, the cell is equipped with six sets of MS manipulators. Most of the workstations are equipped with one CRL model E MS, rated for a 20 -lb vertical lift, and one CRL model F MS, rated for a 100-lb vertical lift.

Two pneumatic transfer stations are inside the decon cell. One station originates at station 4D and runs to the Fuel Conditioning Facility (FCF). The other station originates inside the spray chamber and runs to the radiation safety office (HP office). The pneumatic transfer station that runs to FCF is used for sending small irradiated samples to FCF then on to the Analytical Laboratory (AL) for analysis. 


\subsubsection{Metallographic Loading Box}

The metallographic loading cell is a shielded, gas-tight cell with inside dimensions of $8 \mathrm{ft}$ wide by $6 \mathrm{ft}$ deep by $5 \mathrm{ft}$ high. The cell is provided to accommodate a Leitz metallograph and a scanning electron microscope (SEM) for performing detailed examination of metallurgical samples. The shielding walls (except the front wall) are constructed of 8 -in.-thick lead brick. The front wall is 15 -in. thick and is constructed of three 5-in.-thick steel plates. The front wall has a lead-glass window for viewing and two CRL Model L MS manipulators.

\subsubsection{HRA}

The HRA is a series of rooms located directly above the decon cell and west end of the main cell in the high bay area. The outside dimensions of the HRA are $45 \mathrm{ft}$ by $70 \mathrm{ft}$. The primary purpose of the HRA is to perform contact maintenance on cell equipment. The HRA is divided into 12 areas:

1. Hot Repair Room (HRR)

2. Suspect Repair Room

3. Equipment Access Room (Cart Room)

4. Isolation Area Room

5. Survey Room

6. Health Physics (HP) Office

7. Unsealed Slave Repair Room

8. Bagout Room

9. Sealed Slave Arm Repair Glove Box Room

10. Stepout Area Room

11. Glovewall Room

12. Ancillary Area Room

Most of the rooms in the HRA are specific-purpose rooms used for the repair of MS manipulators and other facility-specific equipment. The HRR can be used for the transfer of equipment and materials between the decon cell and HRA. Both the HRR and Suspect Repair Room are serviced by a 5-ton bridge crane. The crane uses a removable rotating hook for remote positioning of the hook. With the rotating hook removed, the maximum lift inside the repair rooms is $13 \mathrm{ft} 6$ in. With the hook in place the maximum lift inside the HRR is $12 \mathrm{ft} 1$ in. The drum on the crane is provided with enough cable for a 50 - $\mathrm{ft}$ lift so that it can be used for raising and lowering equipment into the decon cell.

A $10 \mathrm{ft}^{2}$ roof hatch is located in the ceiling of the HRR, directly above the decon cell roof hatch. The hatch is provided with a 114-in. diam bagging ring so it can be used for the transfer of equipment and material directly from the high bay area into the decon cell.

The equipment access room (cart room) is designed to be a lock in the transfer path between the high bay area and the HRR. The room is $8 \mathrm{ft}^{2}$ by $20 \mathrm{ft}$ high and has a $6 \mathrm{ft} 4$ in. ${ }^{2}$ hatch in the ceiling. The room is generally maintained clean so equipment and materials can be transferred from the high bay area to the room through the hatch. A 5-ton equipment cart runs between the cart room and the HRR for moving the equipment and materials between the two rooms.

\subsubsection{WCA}

The WCA is used for the characterization and sampling of contact-handled transuranic waste (CH TRU) for the Waste Isolation Pilot Plant (WIPP) performance assessment. The facility consists of the Preparation Room, Transfer Room, Waste Characterization Chamber (WCC), Sludge Preparation glove box, Operations Room and the Equipment Room.

The Preparation Room (PR) is used as a staging area for waste going into and out of the WCC. Waste drums awaiting characterization in the WCC are stored in the PR, and waste that has been characterized and is awaiting shipment back to the Radioactive Waste Management Complex (RWMC) is also stored in the room. Personnel access to the PR is through a vestibule on the south-east corner of the room. Waste 
drums and equipment are brought into the room using the high bay crane through a $10-\mathrm{ft}$ high by 8 -ft wide equipment door on the south wall. High bay crane hook access to the room is through a 2 -ft wide by 17 -ft-long rollup door on the vertical wall and ceiling above the equipment door. Waste drums and equipment are handled inside the PR by a cantilever-style jib crane rated for a $6000 \mathrm{lb}$ SWL. The crane has a lift height of $12 \mathrm{ft} 8 \mathrm{in}$.

The Transfer Room (TR) is where the waste drums are mated with the WCC. Access to the room is through double doors from the PR. The drums are moved into and out of the TR using a drum cart rated at $2,000 \mathrm{lb} \mathrm{SWL}$. In addition to moving the drums into and out of the room, the cart is used to raise and lower the drums to the drum ports on the bot om of the WCC. Once the drums are bagged to the WCC, they are held in position in the drum ports by turnbuckles which fasten between the bottom of the WCC and an adapter plate under the drums.

The WCC is a 16- $\mathrm{ft}$ long by $8-\mathrm{ft}$ high by $8-\mathrm{ft}$ deep glove box used for characterization of CH TRU wastes. The WCC is equipped with shielded viewing windows for personnel protection from low-level gamma and beta radiation. Each windcw is a three-piece assembly consisting of an inner safety glass, a lexan plate, and leaded glass on the exterior. There are two 200-lb dual Titan $7 F$ manipulators and a 1,500-ib articulated jib crane for handling the waste and equipment inside the glove box. A core boring machine is mounted to the top of the glove box over the west drum port and is used for taking samples from sludge drums. There are 28 glove ports on the WCC. These glove ports are located at various heights for waste handling and equipment repair. A transfer port is located on the east end of the WCC for transferring sludge samples to the Sample Preparation glove box.

The Equipment Room (ER) is located above the WCC and houses the filters, piping, and blowers for the WCC ventilation system. In addition to the ventilation equipment, the ER has a repair glove box for repair of the equipment inside the WCC. The glove box is connected to the west end of the WCC through a transfer tunnel. Equipment is raised and lowered from the repair glove box by a hoist inside the glove box.

The Operations Room (OR) is the area around the WCC and Sample Preparation and Transfer glove boxes. The room provides a mezzanine on the west end of the WCC for the Waste Data Acquisition System (WDAS). The WDAS is used for video taping and audio dubbing of the waste handling operations. A computer controlled switcher is used for switching video sources and recorders. The computer control system for the gas sampling system is molunted on the south end of the WDAS.

In addition to the WDAS, the OR provides monitoring and alarm panels for monitoring the status of the WCA. The panel provides flow and oressure information on the WCC, radiation alarms, breathing air alarms, and fire alarms for the inside of the WCC.

The sludge preparation (SP) glove tox is used for preparing sludge samples for shipment to the Idaho Chemical Processing Plant (ICPP) to be analyzed for halogenated VOCs, nonhalogenated VOCs, RCRA heavy metals, and radioassay. After the sludge has been cored, the core section is transferred to the SP glove box where the samples are taken at various locations along the core section. As each sample is taken, it is weighed, placed in a labeled vial, and shipped to ICPP in a Type A container. Some experimentation is being done on real time analysis of the stimples using X-ray florescence. The testing of the equipment has not been completed.

\subsection{ORNL}

The Irradiated Fuels Examination Laboratory (IFEL), Building 3525, has a long history of fuel research and examination. It is part of ORNL and is located in Bethel Valley and Melton Valley, approximately 8 miles southwest of the city of Oak Ridge, Tennessee. For three decades this facility has handled a wide variety of fuels including aluminum clad research reactor fuel, both stainless- and zircaloyclad LWR fuel, coated-particle gas cooled reactor fuel, and numerous one of a kind fuel test specimens. In addition, the facility has also done iridium isotope processing and irradiated capsule disassembly.

The IFEL contains a large horseshoe-shaped array of hot cells which are divided into three work areas (Fig. 14). The hot cells are constructed of 3 -ft-thick concrete walls with oil-filled, lead-glass viewing windows. The inside of surfaces of the $c \epsilon l l$ bank are lined with stainless steel to provide containment of particulate matter and to facilitate decontamination. Special penetrations are provided for the sealed entry of services such as instrument lines, lights, and electrical power. A pair of manipulators are located at each 


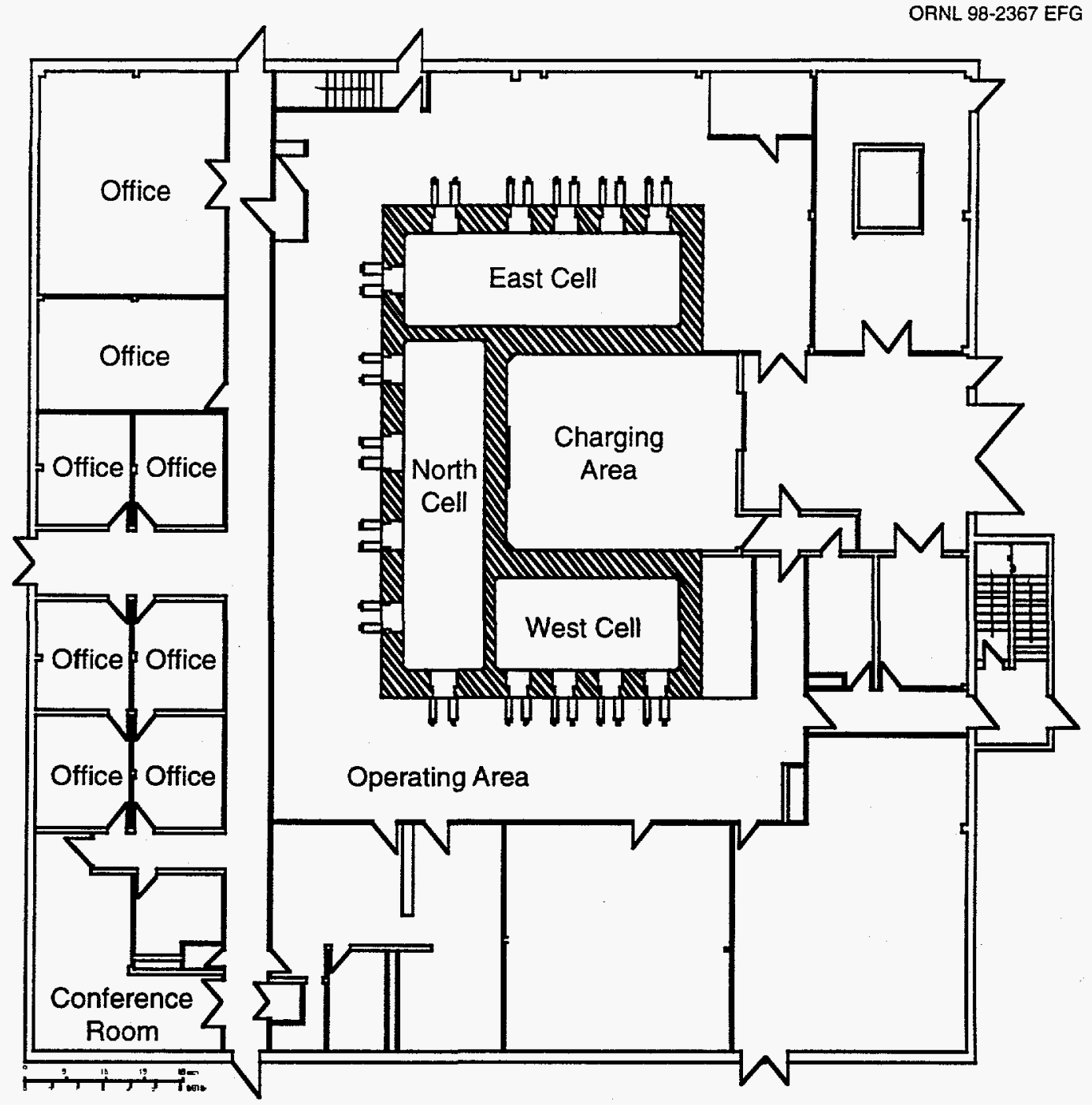

Fig. 14. Building 3525 layout.

of 15 window stations for remote cell operations, and periscopes allow for magnified views of in-cell objects. Heavy objects within each cell bank can be moved by electromechanical manipulators or a 3-ton crane. Fuel materials enter and leave the cells through three shielded transfer stations provided at the rear face of the North cell. Two small diameter (6.5 and $14.5 \mathrm{in}$.) horizontal transfer stations are used for small objects (less than $8 \mathrm{ft}$ in length). Items up to $4 \times 4 \times 6 \mathrm{ft}$ in size can be transferred through the shielded airlock door system.

The remainder of the laboratory outside the hot cell complex is subdivided into: (1) the charging area; (2) the equipment maintenance air lock areas; (3) the operating area; (4) the truck unloading area, the change room, and a work room; and (5) the rooms housing supporting mechanical equipment. Located on the east side of the truck unloading area is a small laboratory which houses the Core Conduction Cooldown Test Facility (CCCTF). The CCCTF is used to test radioactive samples under controlled thermal conditions while monitoring the samples to determine the release rate of radioactive materials.

A decontamination cell and storage cell, located on the second floor of the building, are connected via hatches to the cells below. A maintenance area incorporating glove box facilities for servicing equipment items adjoins the decontamination cell. Sliding doors separate the decontamination cell, storage cell, and glove maintenance room; a remote crane system provides for retrieval of equipment into and transfer of 
items between these second-floor facilities. Equipment may be transferred between cells through the second-floor pathway. An upper level of the second floor houses ventilation system ducts, control valves, high efficiency particulate air filters, heat exchangers, and air inlets for the equipment storage area, the decontamination area, and the glove maintenance area.

Gases and particulates exhausted rom the cell complex are completely contained and shielded until subjected to sufficient filtration to ensure safe stack disposal. The cell air is maintained at negative pressure with respect to the operating areas to en sure confinement. Liquid effluent from the hot cells is handled in a batch mode for disposal to the ORNL lo'N-level liquid waste system.

A variety of shears, machine tools, and cutoff saws are available within the cell for the gross handling and preparation of fuel specimens. The facility has experience in the handling and cutting of a wide variety of capsule and clad materials such as Inconel, stainless steel, zircaloy, aluminum matrix, and graphite-based materials. A gamma scanner is available for the nondestructive examination of moderate-length fuel rods and individual specimens. Metrology ec|uipment such as mass scales and dimensional tools are routinely used and available.

Metallographic equipment including small cutoff saws, polishers, and a shielded metallograph are available for the preparation, handling, and examination of both fuel specimens and clad material. The facility has prepared samples of oxide fuels, carbide fuels, and metal matrix fuels.

Building 3525 also has other facilities outside the main bank of cells: a scanning electron microscope that can handle radioactive specimens, additional gamma analysis and dosimetry equipment for both centimeter-sized and submillimeter-sized samples, and a small stand-alone hot cell with specialized equipment for the handling and analysis of coated-particle fuels.

Radiochemical specimens can be prepared within the facility and delivered to other ORNL laboratories for detailed analysis. ORNI_ also has extensive computational abilities that can be used to process the hot cell data for comparison with fuel performance models.

PIE capabilities of the IFEL have jrovided general support to fuels program, fuel characterization, and analysis of candidate irradiated fuel. Typically, the fuel is received at the IFEL, dimensionally inspected, visually examined for defects and gamma scanned for internal fuel gaps or cracks along with gross fission product migration. The fuel can then be removed from its casing or clad and fuel and clad specimens prepared for metallographic examination, gamma counting, and radiochemical analysis. Actinide and fission product inventories can be determined along with burnup and radial isotope distributions within the fuel. The mechanical properties of the specimens can also be investigated to determine the state of the fuel and/or clad materials. All work is typically done with proper procedures and documentation after concurrence is obtained from the program participants.

Recent work includes extensive support for the Gas Turbine Modular High-Temperature Gas-Cooled Reactor (GT-MHR) program, the New Production Reactor (NPR), a cooperative gas-cooled reactor agreement with Japan, and handling of legacy fuel under the National Spent Fuel program. Personnel are available with experience in a wide variety of fuel PIE programs and analysis techniques along with the detailed reporting and quality control requirements for nuclear programs. The Metals and Ceramics (M\&C) division contains a wealth of experience in fuel fabrication, metal and ceramic material behavior, irradiated material behavior, and material testing. Ongoing programs at ORNL maintain experience in hot cell techniques and analysis. In addition, academic and industrial consultants are available to meet special program needs and to conduct reviews. 


\section{REFERENCES}

1. U.S. Department of Energy, Guidelines for Use of Probabilistic Seismic Hazard Curves at Department of Energy Sites for Department of Energy Facilities, DOE-STD-1024-92.

2. Woodard-Clyde Federal Services (WCFS), Seismic Hazards Evaluation of the Los Alamos National Laboratory, ENG-MPO-93-BCMR, Draft Final Report, June-1, 1993.

3. TA-55 Final Safety Analysis Report, LA-CP-95-169, Rev. 1.

4. U.S. Nuclear Regulatory Commission, Development of Criteria for Seismic Review of Selected Nuclear Power Plants, NUREG/CR-0098, May 1978.

5. U.S. Department of Energy, Natural Phenomenon Hazards Design and Evaluation Criteria for Department of Energy Facilities, DOE-STD-1020-94.

6. DOE Safety Evaluation Report, January 13, 1997.

7. DOE Order 5480.23, Nuclear Safety Analysis Reports.

8. DOE Order 5480.22, Technical Safety Reports.

9. Atomic Energy Commission, AEC Manual, Chap. 6301, General Design Criteria.

10. Los Alamos National Laboratory, Response to the Surplus Plutonium Disposition Environmental Impact Statement Data Call for a Mixed Oxide Fuel Fabrication Facility Located at the Pantex Plant, LAUR-97-2067, Rev. 3, June 22, 1998.

11. V. S. White, Initial Data Report and Response to the Surplus Plutonium Disposition Environmental Impact Statement Data Call for the UO 2 Supply, ORNL/TM-13466, Draft, Lockheed Martin Energy Research Corporation, Oak Ridge National Laboratory, August 1997.

12. Shearon Harris Nuclear Power Plant Technical Specifications, Sect. 3.8.

13. U.S. Department of Energy, Airborne Release Fractions/Rates and Respirable Fractions for Nonreactor Nuclear Facilities, DOE-HDBK-3010-94, Vols. I and II, December 1994. 1986.

14. Browne and Firestone, Table of Radioactive Isotopes, V. S. Shirley, ed., John Wiley and Sons,

15. U.S. Department of Energy, Criteria for Preparing and Packaging Plutonium Metals and Oxides for Long-Term Storage, DOE-STD-3013-96, September 1996.

16. DOE Order 420.1 , Sect. 4.3 , Nuclear Criticality Safety.

17. 40 CFR 302.4, Table 302.4, List of Hazardous Substances and Reportable Quantities.

18. W. R. Stratton, A Review of Criticality Accidents, DOE/NCT-04, March 1989. 

Appendix A-LA FUEL BUNDLE FABRICATION

A-1 
Page Intentionally Blank

A-2 
$\mathrm{PuO}_{2}$

\begin{tabular}{|c|}
\hline SST Shipment Receipt \\
\hline$t$ \\
\hline Shipment Verification \\
\hline$t$ \\
\hline Product Vault Storage \\
\hline$t$ \\
\hline Ship to Fabrication Facility \\
\hline$t$ \\
\hline Open Cans \\
\hline 1 \\
\hline Inspection \\
\hline Assay \\
\hline Chemistry \\
\hline Particle Attributes \\
\hline 7 \\
\hline Disposition \\
\hline$\downarrow$ \\
\hline Ilutonium Production Storage \\
\hline
\end{tabular}

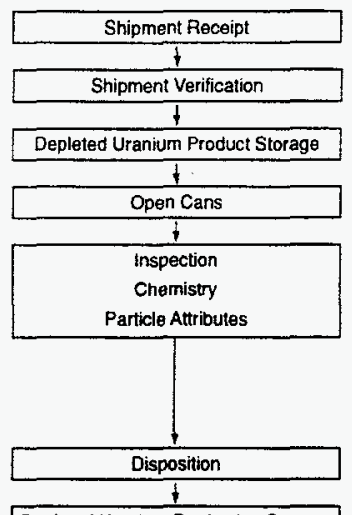

Prepare Master Mix (30\% Plutonlum) Powder

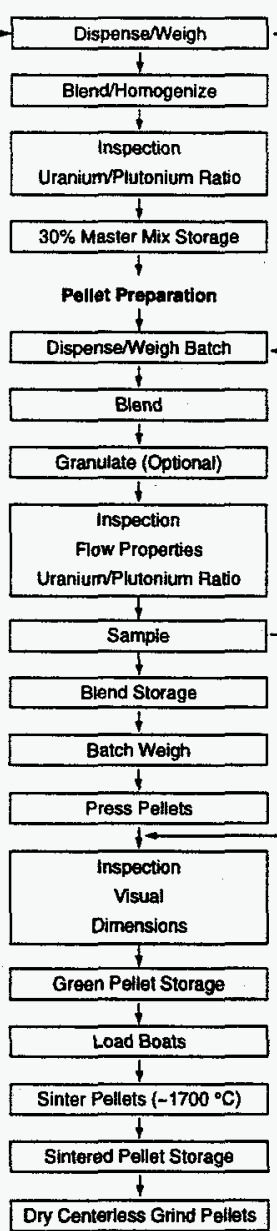

Dry centerioss ary

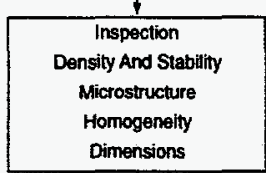

Dimension $t$

Depleted Uranium Production Storage
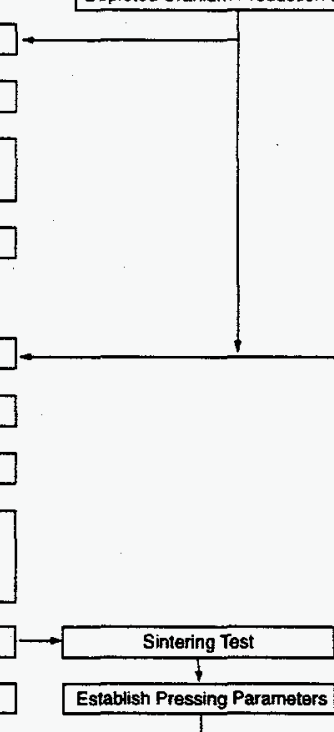

Depleted $\mathrm{NO}_{2}$

Hard Scrap Recycle (Depleted Uranium/Plutonlum) (Up To $10 \%$ of Batch Makeup) From Sintered Pellel Scrap From

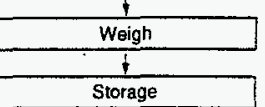

Crush (Jaw Crusher)

1

Grind (Ball Milt)

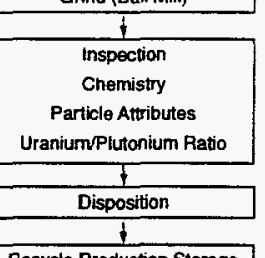

Finished Pellat Storage

Fig. A.1. LA MOX fuel pellet flow sheet outline. 


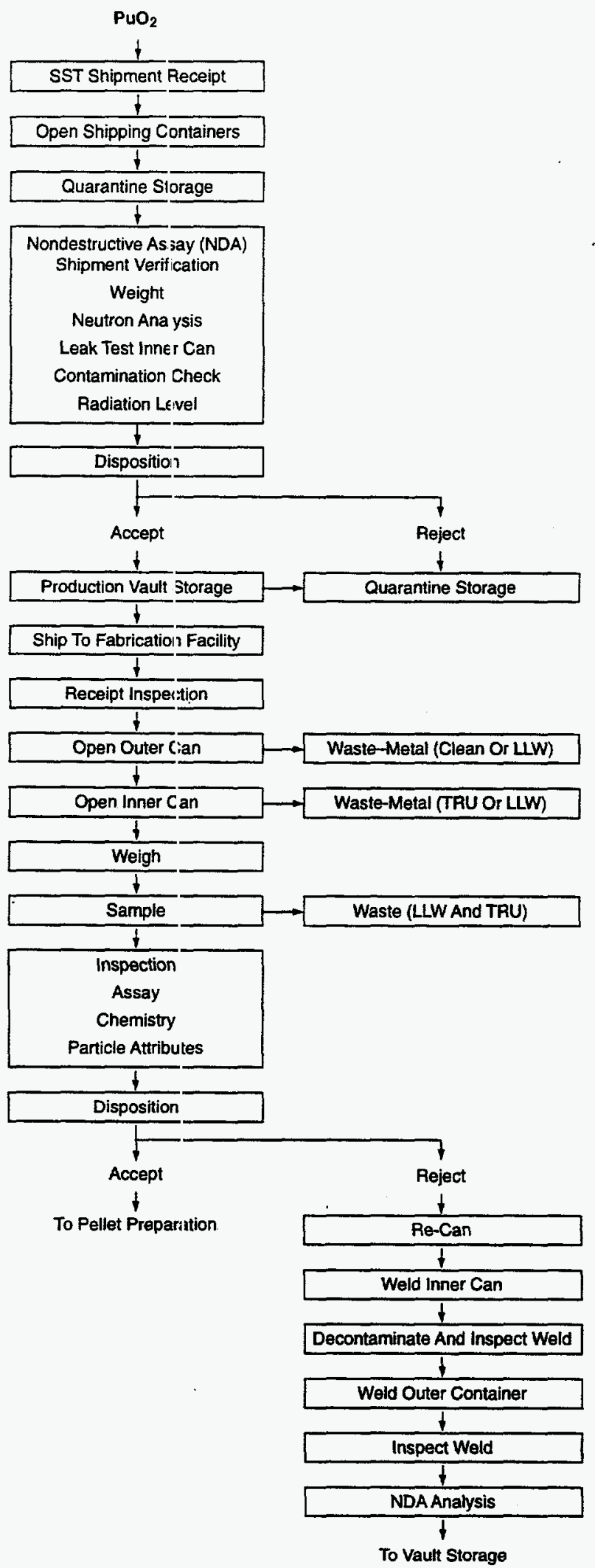

Fig. A.2. LA MOX fuel $\mathrm{PuO}_{2}$ powder receipt and storage.

A-4 


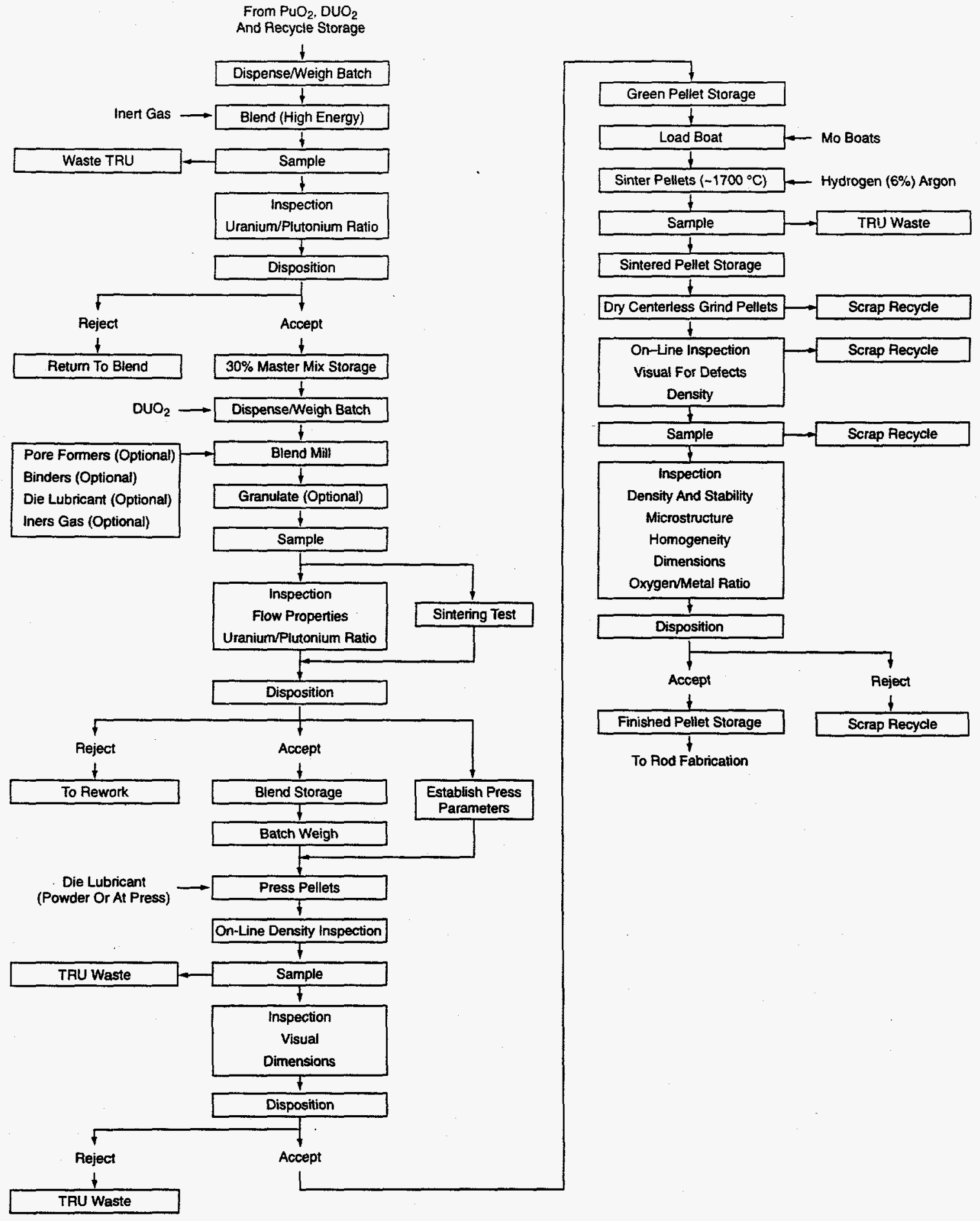

Fig. A.3. Detailed flow sheet of LA pellet fabrication. 


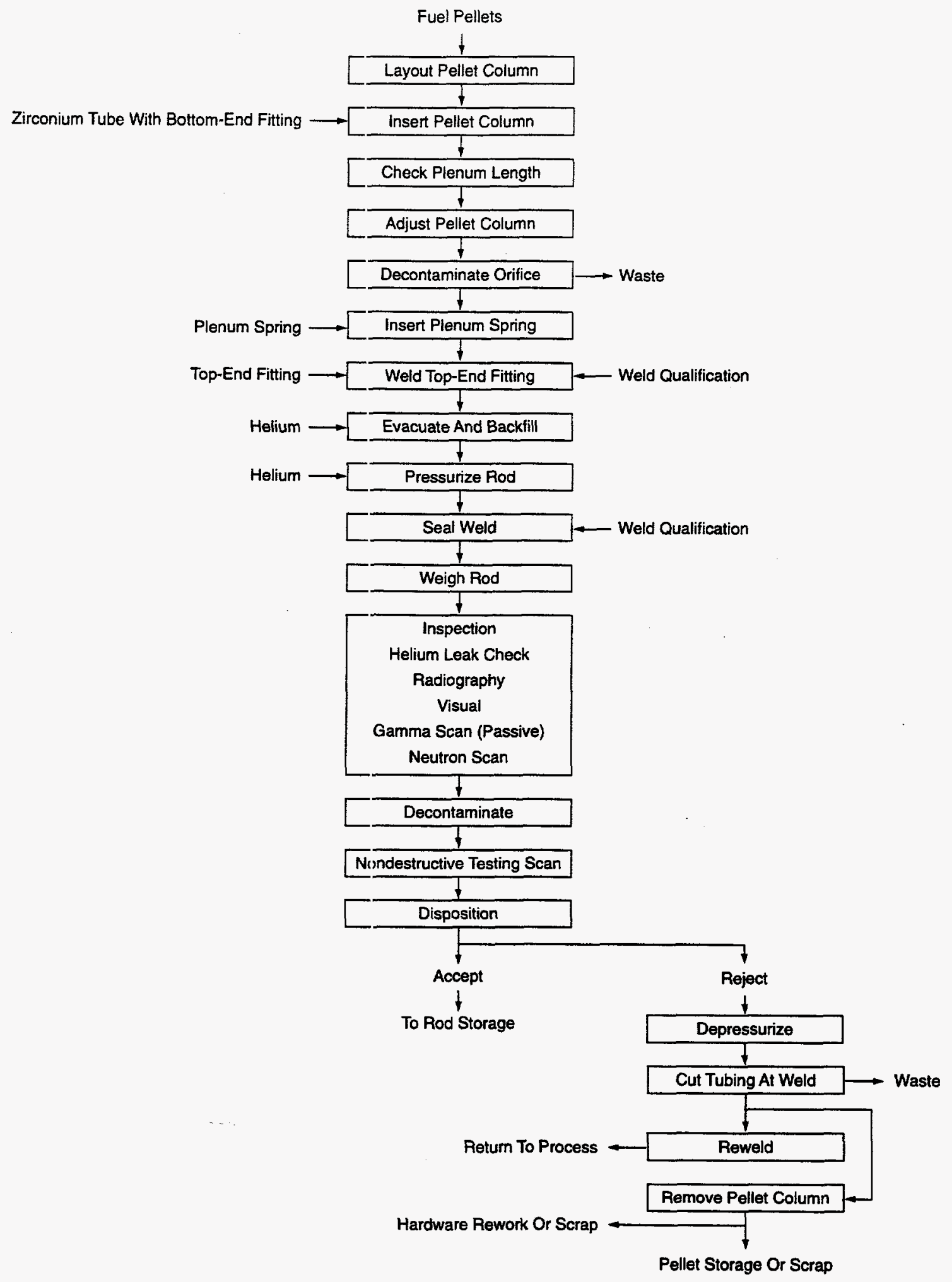

Fig. A.4. Detailed flow sheet of LA rod fabrication. 


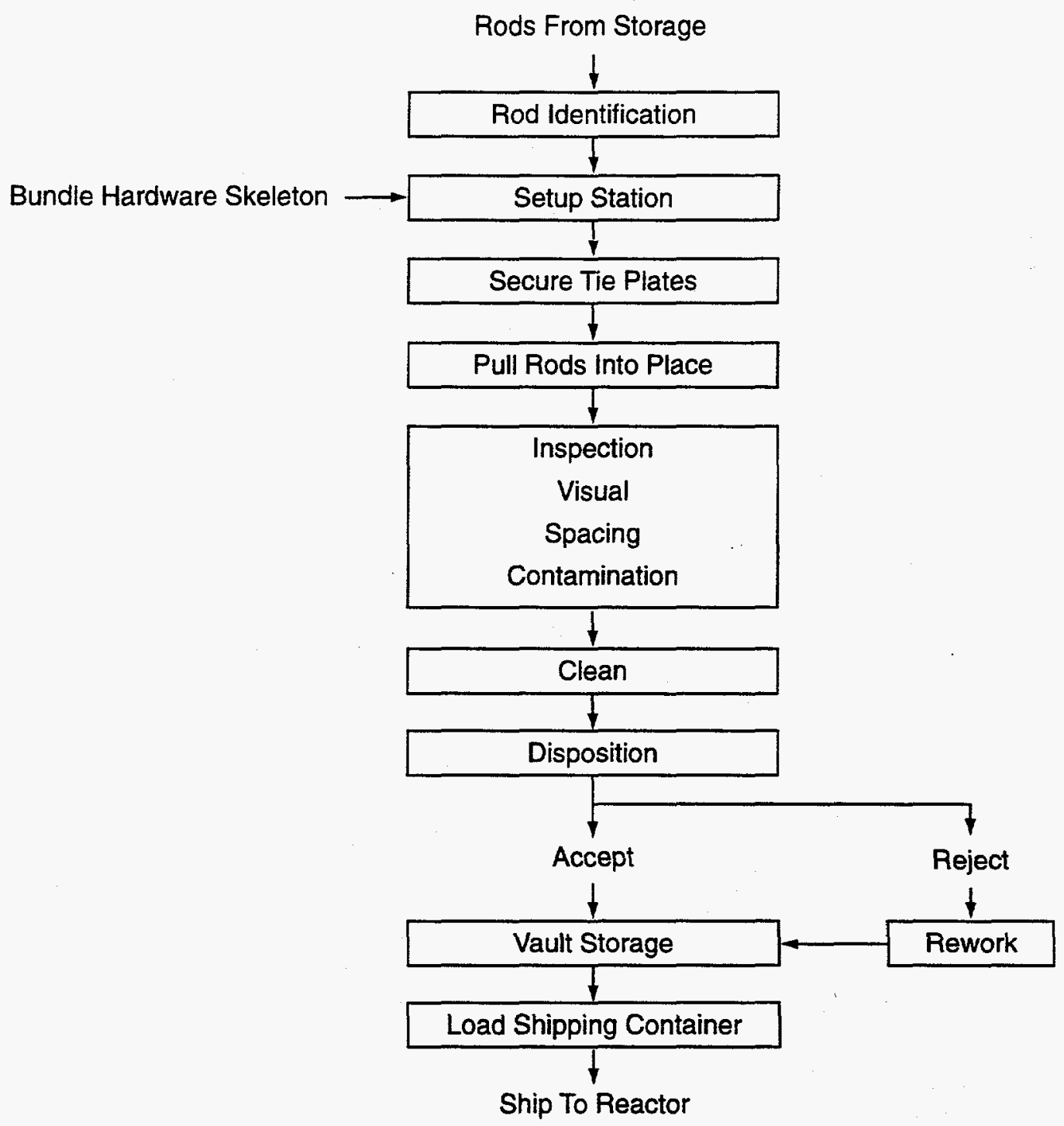

Fig. A.5. Detailed flow sheet of LA bundle assembly (LWR). 
Page Intentionally Blank 
Appendix B-LA EIS DATA REPORT ASSUMPTIONS

B-1 
Page Intentionally Blank 
Table B.1. Assumptions used for the LA EIS data reports

1. Material and process requirements are based on producing PWR fuel.

2. $\mathrm{PuO}_{2}$ powder will meet the ASTM C 757-90 specification as received.

3. Depleted $\mathrm{UO}_{2}$ powder will meet the ASTM specification as received.

4. Depleted $\mathrm{UO}_{2}$ (no $\mathrm{PuO}_{2}$ ) will be used to perform all system shakedown tests before introducing plutonium.

5. Table 3 is in terms of $\mathrm{HM}$. The factor for converting $\mathrm{PuO}_{2}$ and depleted $\mathrm{UO}_{2}$ to $\mathrm{HM}$ is $88 \%$.

6. All waste plutonium will be canned and sent to the Immobilization Program for final disposition.

7. All plutonium scrap will be recycled using a dry process.

8. All liquid wastes generated are ancillary to the base process (i.e., laundry, mop water, etc.)

9. Sintering furnaces will stay at temperature during the entire 3-year mission and 1-year startup.

10. Sintering furnaces will be purged with a mixture of argon and $6 \%$ hydrogen at a rate of $10 \mathrm{~L} / \mathrm{min}$.

11. Powder glove boxes will be purged with nitrogen to reduce the potential for oxidizing $\mathrm{UO}_{2}$.

12. All calculated numbers have a precision of no more than two significant figures.

13. The facility will be built on an existing DOE site with a minimum of $4500 \mathrm{ft}^{2}$ available space $\left(3000 \mathrm{ft}^{2}\right.$ for MOX rod processing, $1000 \mathrm{ft}^{2}$ for bundling activities, and $500 \mathrm{ft}^{2}$ for fuel bundle storage).

14. The site will have an existing infrastructure in place to accept the LA mission.

15. Personnel will be required to support a process capacity of $\sim 2$ MT HM per year.

16. Personnel involved in SNM operations must work in pairs and follow specific safety precautions detailed by the site.

17. Personnel must attend required site training. A staffing requirement for training purposes has been included in this estimate.

18. Space will be allocated for safe secure transports (SSTs) carrying plutonium and transportation for uranium so that loading can be accomplished on a follow-up operating shift if the transport arrives near or following the close of standard business.

19. As with the MOX fuel fabrication facility estimate, the staffing requirements assume that $-20 \%$ of the employee's time will be taken through training, vacation, personal leave, or illness. Even though employees cannot necessarily transition from one position to another, a contingency was added to account for nonproductive time.

20. Homogenization of the $\mathrm{PuO}_{2}$ powder will be done at the LA fuel fabrication facility, as will gallium removal operations. 
Page Intentionally Blank 


\section{LANL RESPONSE TO THE SUPPLEMENTAL LEAD TEST ASSEMBLY EIS DATA CALL}


Page Intentionally Blank 


\section{LANL RESPONSE TO THE SUPPLEMENTAL LEAD TEST ASSEMBLY EIS DATA CALL}

\section{GENERAL SITE DATA NEEDS}

Los Alamos National Laboratory (LANL) is a multiprogram laboratory with the central mission of reducing nuclear danger. In the past, this mission primarily included nuclear weapons research, development, and testing, but it has recently expanded into the following areas:

- stockpile stewardship activities,

- stockpile support projects,

- nuclear materials management,

- effective nonproliferation and counterproliferation technologies, and

- cleaning up the legacy of 50 years of weapons production.

The laboratory also continues its involvement in defense activities such as nuclear weapons technology and civilian problems, including health, national infrastructure, energy, education, and environment.

The latest available annual site environmental monitoring report, entitled Environmental Surveillance at Los Alamos during 1995 (LA-13210-ENV), can be found by accessing the World Wide Web at the following URLs: //lib-www.lanl.gov/la-pubs/00326112.pdf (pp. i-xix, 1-146) and http://lib-www.lanl.gov/la-pubs/00326113.pdf (pp. 147-300).

At the end of July 1997, the LANL workforce consisted of 8466 University of California employees and 1079 contractors, for a total of 9545 workers. ${ }^{1}$ Table 1 shows the doses obtained by a worker at LANL during the past 3 years. ${ }^{2}$

The Office of Fissile Materials Disposition (MD) mixed oxide (MOX) lead assembly (LA) fabrication activities at LANL will primarily take place at the Plutonium Facility-4 (PF-4), which is located in Technical Area 55 (TA-55). Air emissions resulting from these activities would contribute to less than $1 \%$ of total air emissions from PF-4, which is an insignificant amount compared to the total amount of air emissions released from the entire laboratory. Furthermore, current MOX fuel fabrication activities at PF-4 also contribute to workers' doses, employment, air emissions, water discharges, and waste generation rates presented in this document. LA fabrication would consequently have even less of an impact than estimated in this report.

Both minority and low-income populations live in the Los Alamos area, but no additional environmental effects on these populations should occur because there are no significant environmental consequences for LA fabrication. Thus, no environmental justice issues or activities are associated with the site.

Table 1. Doses to average LANL worker

\begin{tabular}{cccc}
\hline Year & $\begin{array}{c}\text { Dose to average } \\
\text { worker (mrem) }\end{array}$ & $\begin{array}{c}\text { Dose to average } \\
\text { radiation worker } \\
\text { (mrem) }\end{array}$ & $\begin{array}{c}\text { Total dose } \\
\text { (person-rem) }\end{array}$ \\
\hline 1994 & 15 & 75 & 178 \\
1995 & 18 & 88 & 235 \\
1996 & 16 & 91 & 180 \\
\hline
\end{tabular}

\section{LOCATION-SPECIFIC DATA NEEDS}

The LA fabrication effort at LANL is proposed to take place at several different facilities, each of which is specially designed and equipped to handle different steps of the process. The fuel fabrication and rod loading/welding would be performed at TA-55 in PF-4. The bundle assembly and inspection could be 
performed at any of a number of facilities, including the Radioactive Materials Research, Operation, and Demonstration Facility (RAMROD), thie Chemistry and Metallurgy Research (CMR) Building at TA-3 or one of the Critical Assembly Building Kivas at TA-18. Bundle storage is proposed to occur in the basement area of PF-4, and from there the bundle; will be loaded onto safe secure transports (SSTs) for transport offsite. These and other facilities of interest (i.e., waste handling facilities) are discussed in the following paragraphs, and Table 2 summarizes the functions proposed for each facility. Their locations with respect to other laboratory areas and the towns of Los Alamos and White Rock can be seen on Fig. 1.

TA-55/PF-4. TA-55, the plutonit.m facility complex, is one of the larger technical areas at LANL. The facilities at TA-55 are located on a 16-ha (40-acre) site about $1.6 \mathrm{~km}$ (1 mile) southeast of TA-3. The primary research and development facility at TA-55 is PF-4. All plutonium entering or exiting TA-55 is processed at this facility, which is a two-story laboratory with a surface area of approximately $14,000 \mathrm{~m}^{2}$ $\left(151,000 \mathrm{ft}^{2}\right.$ ). The main complex has five connected buildings (see Fig. 2): Administration Building (PF-1), Support Office Building (PF-2), Support Building (PF-3), Plutonium Facility (PF-4), and Warehouse (PF-5). PF-4 is classified as a Safeguards Category I and a Hazard Category II nonreactor nuclear facility and was built to comply with seismic stendards for Safeguards Category I buildings. The ventilation system in the facility has four zones. The overall design concept for PF-4 separates the building into two halves. Each half operates as a separate building with its own filtered exhaust stack. Various ongoing activities at PF-4 include plutonium recovery; fabrication of plutonium components; disassembly of weapons components; actinide processing, research, and development; processing of ${ }^{238} \mathrm{Pu}$; and fabrication of ceramic-based reactor fuels.

For the LA fabrication effort, most of the activities are proposed to occur within PF-4. The operational fuel fabrication laboratories: (Rooms 125 and 126) will be used with minor modifications to fabricate the LA fuel. Already planred upgrades to Room 124 (next door to the fuel fabrication laboratories) could provide on-site analytical chemistry capability for the LA fabrication effort. It is most likely, however, that the majority of the analytical chemistry activities will take place in the already operational laboratories within the CMR. Facility. The rod loading and welding activities are also proposed for PF-4, in Room 201. Although the bundle assembly is proposed to take place elsewhere (i.e., CMR building), the bundle storage could be done in PF-4, most likely in the basement area.

TA-3/CMR Building. TA-3 (see Fig. 3) is LANL's main and largest technical area, both in terms of the amount of land space and the number of personnel. It houses a variety of projects and contains a number of buildings/facilities, including the CMR building (see Fig. 4). This building was designed within TA-3 as an actinide CMR facility. The inain corridor contains seven wings that were constructed in 1952. In 1960, a new wing (Wing 9) was added for activities that must be performed in hot cells. The three-story building now has eight wings connected by a spinal corridor and contains a total of $51,000 \mathrm{~m}^{2}\left(550,000 \mathrm{ft}^{2}\right)$ of space. Each wing is associated with different activities. It contains hot cells and special nuclear material (SNM) vaults and is now the only LAJNL facility with full capabilities for performing SNM analytical chemistry and materials science in support of the nuclear weapons program. It is currently designated as a Safeguards Category III and Hazard Category II nuclear facility, with some Safeguards Category I capabilities.

Table 2. Fotential functions for each facility

\begin{tabular}{lccccccc}
\hline Facility & $\begin{array}{c}\text { Pellet } \\
\text { fabrication }\end{array}$ & $\begin{array}{c}\text { Rod } \\
\text { fabrication }\end{array}$ & $\begin{array}{c}\text { Bundle } \\
\text { assembly }\end{array}$ & $\begin{array}{c}\text { Analytical } \\
\text { chemistry }\end{array}$ & $\begin{array}{c}\text { Waste } \\
\text { management }\end{array}$ & $\begin{array}{c}\text { Bundle } \\
\text { storage }\end{array}$ & $\begin{array}{c}\text { Transpor- } \\
\text { tation }\end{array}$ \\
\hline TA-55/PF-4 & $\mathrm{X}$ & $\mathrm{X}$ & $\mathrm{X}$ & $\mathrm{X}$ & & $\mathrm{X}$ & \\
TA-3/CMR & & & $\mathrm{X}$ & $\mathrm{X}$ & & $\mathrm{X}$ & \\
TA-18/kivas & & & $\mathrm{X}$ & & & $\mathrm{X}$ & \\
TA-50/RAMROD & & & $\mathrm{X}$ & & & & \\
TA-50/WCRRF & & & $\mathrm{X}$ & & $\mathrm{X}$ & $\mathrm{X}$ & \\
TA-54 & & & & $\mathrm{X}$ & & $\mathrm{X}$ \\
Pajarito road & & & & & & \\
\hline
\end{tabular}




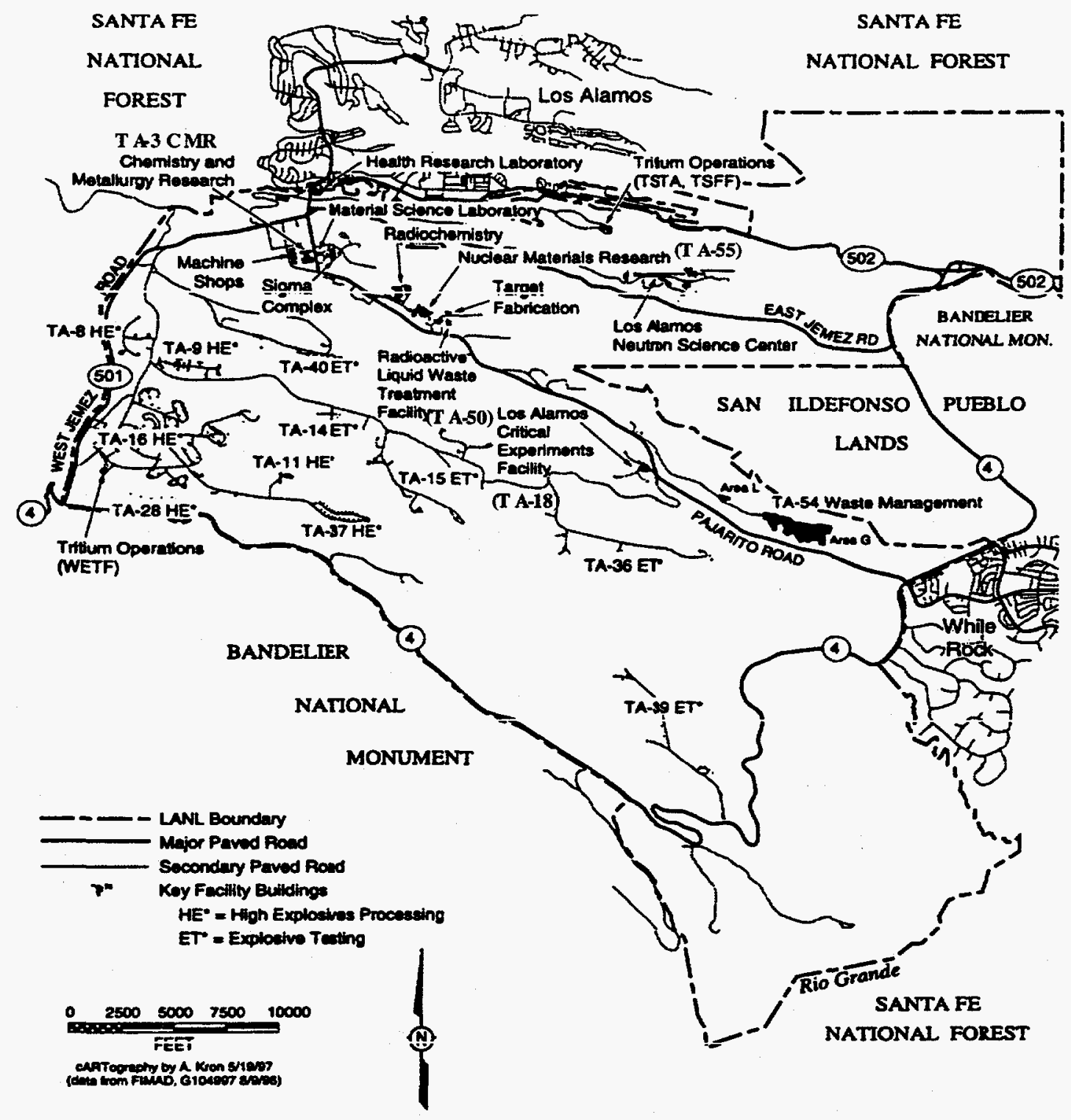

Fig. 1. Locations of LANL TAs. 


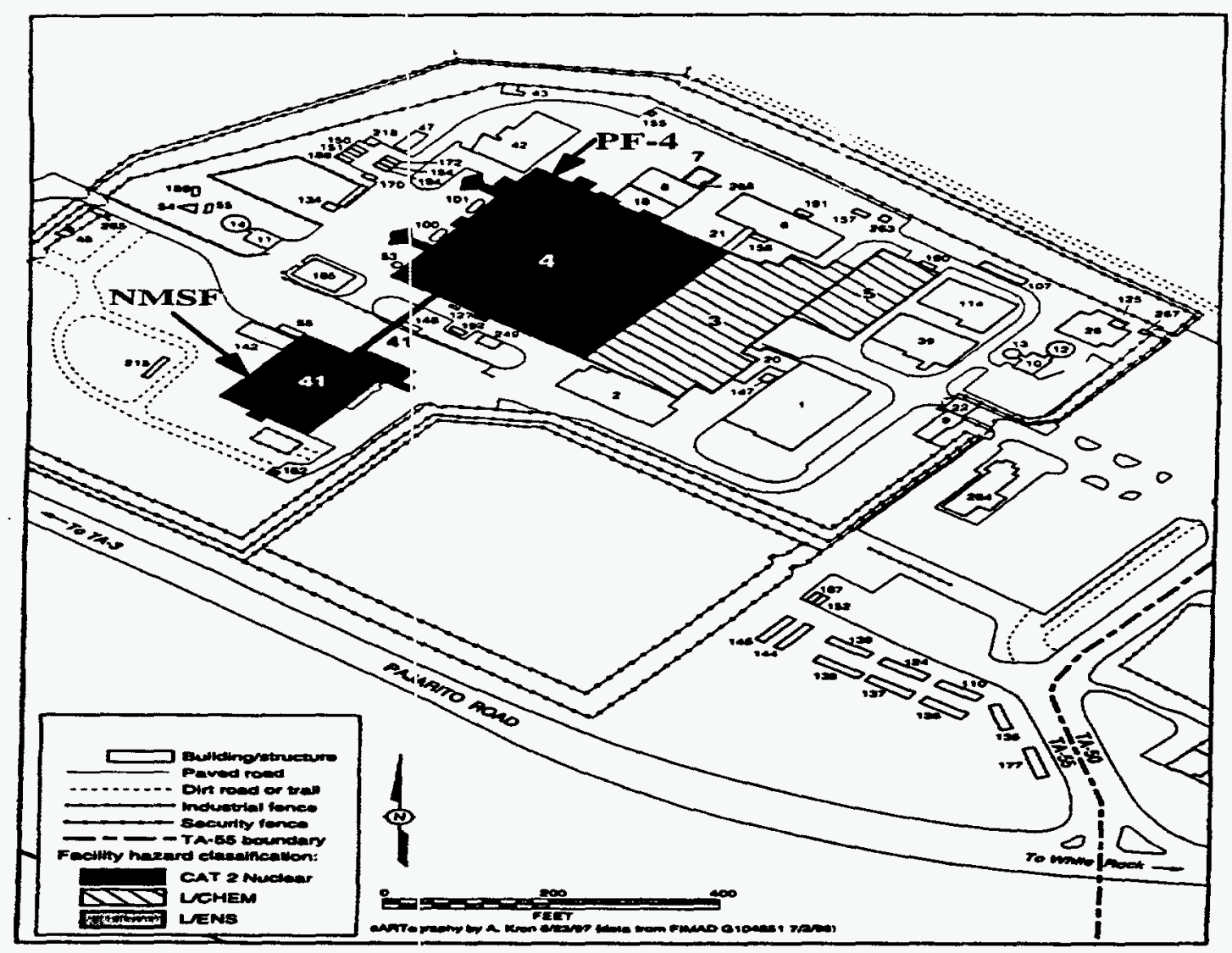

Fig. 2. Facilities at TA-55.

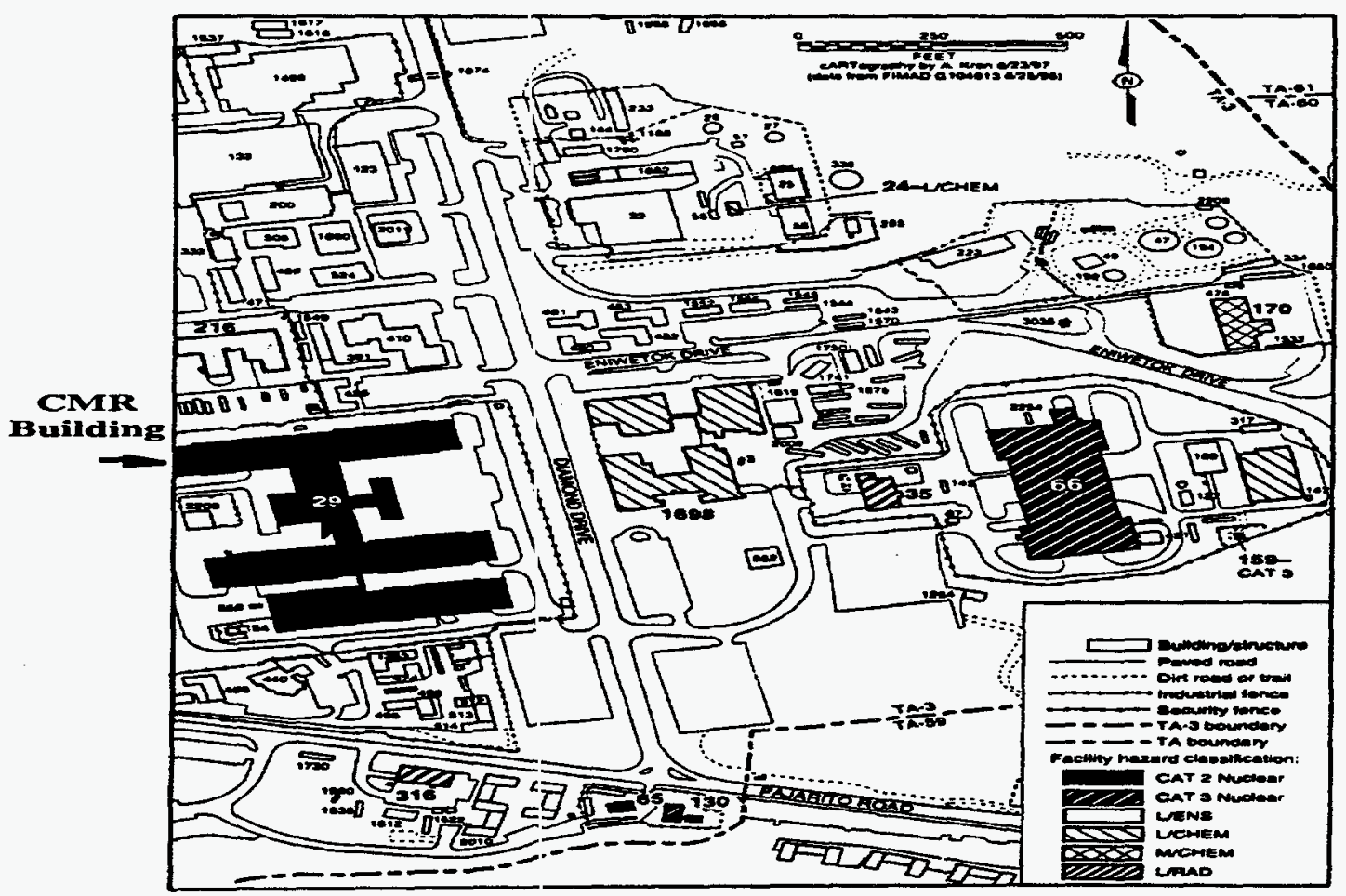

Fig. 3. Facilities in TA-3. 


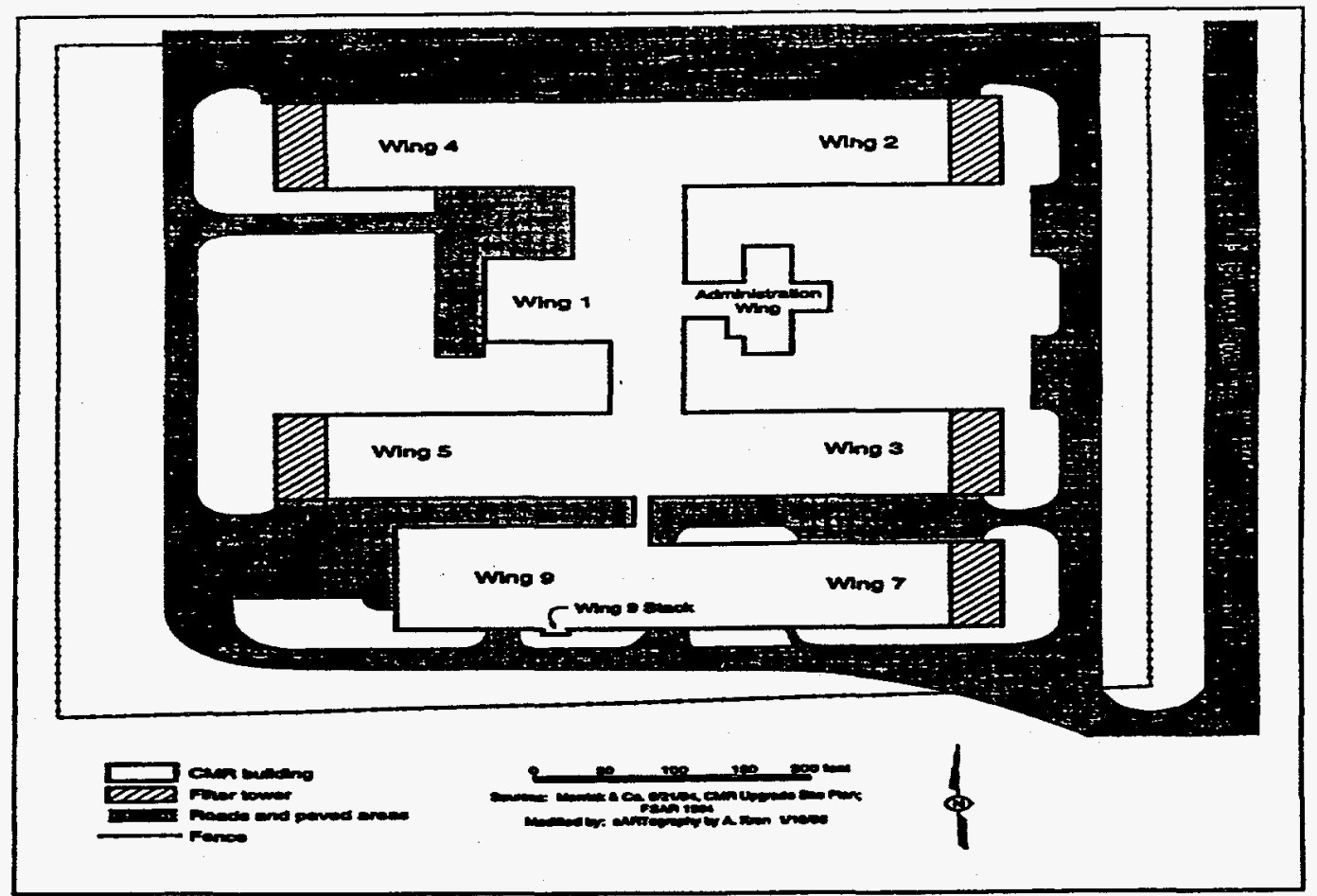

Fig. 4. CMR building layout.

The CMR facility hosts a variety of activities such as analytical chemistry, uranium processing, destructive and nondestructive analysis, actinide research and processing, fabrication and metallography. Enough waste treatment and pretreatment is conducted within the facility to sufficiently meet waste acceptance criteria for both on- and off-site receiving facilities. In addition to being the primary location for many projects, these facilities are used to support various activities at other LANL locations.

Analytical chemistry capabilities involving the study, evaluation, and analysis of radioactive materials are present at the CMR building. These activities support various nuclear materials programs, many of which are performed at other LANL locations. Analytical activities include assay and determination of isotopic ratios of plutonium, uranium, and other actinides; major and trace elements in the materials; interstitial gases analysis; highly sensitive surface analysis techniques; and methods to determine environmentally important waste constituents on highly radioactive materials.

The high bay in Wing 9 of the CMR building is an area proposed for the assembly of bundles and bundle inspection. Bundle storage might be an option in the CMR facility, but it will most likely be restricted to a temporary basis while bundles are awaiting transport to PF-4. The CMR facilities will also most likely be the location of much of the analytical chemistry activities for this project.

TA-18. Another facility being considered for the assembly of fuel rods into bundles is the Los Alamos Critical Experiments Facility (LACEF), TA-18, which is located in arid Pajarito Canyon about 6.4 km (4 miles) southeast of TA-3 on Pajarito Road. LACEF has operated since 1946 and is one of the last general-purpose nuclear experimental facilities in the United States. Its activities include national security programs such as the Nuclear Emergency Search Team, Strategic Defense Initiative research, and Strategic Arms Reduction Treaty verification research; and the development of instrumentation for nuclear waste assay and high-explosives detection. The current primary purposes of LACEF are the design, construction, research, development, and application of critical experiments as well as teaching and training criticality safety and other applications of radiation detection and instrumentation. TA-18 is a restricted area containing many security fences and extra layers of security and safeguard protection. Four buildings 
within TA-18 are Hazard Category III Nuclear Facilities: Critical Assembly Buildings Kivas 1, 2, and 3 (see Fig. 5) and the Hillside Vault. These three kivas are classified as Safeguards Category I. Each of these kivas is surrounded by security fences and additional security and safeguard precautions. Each kiva has metal lockers used to store spent nuclear fuel containers, and load limits are placed on the vaults. These vaults can only be accessed from the entrance to the kiva. Kiva 1 is $134 \mathrm{~m}^{2}\left(1440 \mathrm{ft}^{2}\right)$ in area; Kiva 2 is about $162 \mathrm{~m}^{2}\left(1740 \mathrm{ft}^{2}\right)$; and Kiva 3 has an area of $\sim 482 \mathrm{~m}^{2}\left(5184 \mathrm{ft}^{2}\right)$.

Kiva 3 contains the most shielding of the three because it is located closest to occupied buildings, while Kivas 1 and 2 do not require as much shielding because they are located farther away. It is proposed that one of these kivas may be used to assemble and inspect fuel bundles for the lead test assemblies (LTAs).

TA-50. TA-50 is a Laboratory Waste Management Site located near the center of the laboratory. It exists on 25 ha (62 acres) of land, which include 33 waste management structures such as trailers, tanks, storage sheds, as well as four buildings (see Fig. 6). The following waste activities take place at TA-50: radioactive liquid waste treatment; decontamination of respirators, equipment, instruments, vehicles, and other waste items; and size reduction and characterization of transuranic (TRU) wastes. The facilities are capable of storing and disposing of both solid and liquid low-level radioactive waste (LLRW), low-level mixed waste (LLMW), TRU waste, and hazardous waste. Major facilities at the area include the Radioactive Liquid Waste Treatment Facility (RLWTF); the Waste Characterization, Reduction, and Repackaging Facility (WCRRF); and the Radioactive Materials Research, Operations, and Demonstration (RAMROD) Facility.

Special lines and a concrete vault allow acid and caustic radioactive liquid wastes from TA-55, which contain relatively high amounts of americium and plutonium, to be treated and pretreated at TA-50. The aqueous waste from radioactive activities and other nonhazardous aqueous chemical wastes at the CMR facility are also discharged into a netw'ork of drains and transported to TA-50 for treatment and disposal. The small amount of liquid wastes resulting from chemical analyses on plutonium, uranium, and MOX fuel samples are put in bottles and shipped to TA-55 where they eventually enter the liquid waste stream to TA-50.

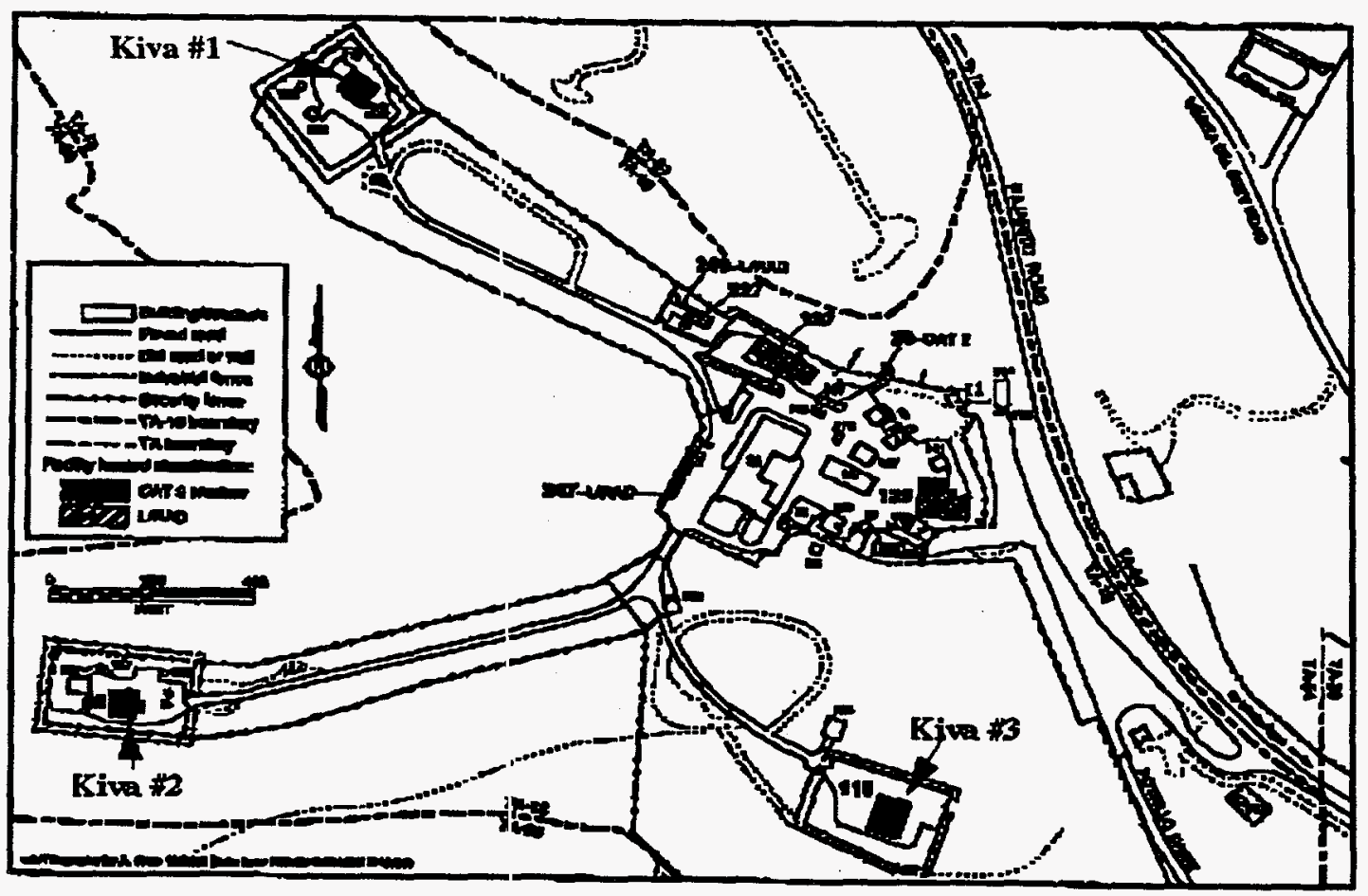

Fig. 5. Facilities at TA-18. 


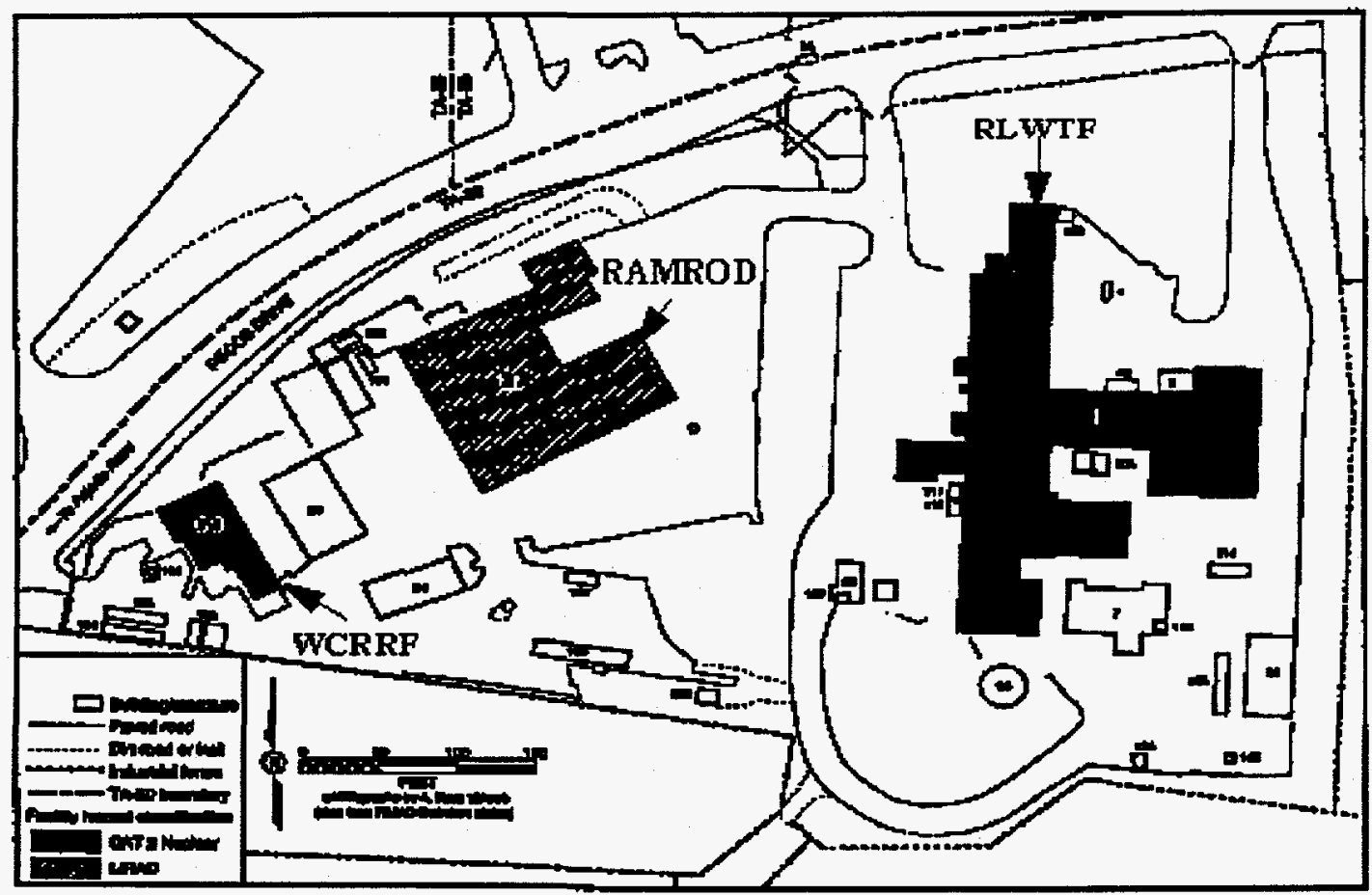

Fig. 6. Facilities at TA-50.

Once wastes are treated, they are packaged to be transported to TA-54 (see next section) for disposal (LLW) or retrievable storage (TRU) until they can be shipped to a long-term storage facility. Two buildings in TA-50 are designated as Hazard Category II Nuclear Facilities: the RLWTF and the WCRRF. The RLWTF is the building to which the acid and caustic wastes generated at TA-55 are transported. The WCRRF building is where TRU wastes are packaged to be transported to TA-54. The RAMROD facility is also a candidate Hazard Category II nuclear facility, but instead it currently performs combustion-based volume reduction and chemical stabilization of TRU-contaminated solid wastes and polychlorinated biphenyls as well as other waste streams.

The facilities at TA-50 will be used for the liquid waste management functions of this project. The WCRRF and RAMROD buildings are also possible candidates for the bundle assembly and inspection activities.

TA-54. TA-54, also one of the largest laboratory facilities, is the main location for solid radioactive and hazardous chemical waste management and disposal. It has been active since 1957 and is predicted to remain open in the future. The facilities in TA-54 are grouped into various designated regions, including Areas G, H, J, and L (see Fig. 7). Area G is the LLW management area. Area $\mathrm{H}$ is a Resource Conservation and Recovery Act (RCRA) site previously used to dispose radioactive wastes (until 1986); Area $\mathrm{J}$ is a classified solid and nonhazardous waste management site; and Area $L$ is the location of chemical waste management activities. The area that will be used to handle wastes from MOX fuel fabrication is Area G. It is here that the solid LLW and TRU wastes typically packaged at TA-55 or TA-50 will be shipped.

TA-54 is considered to be an environmentally prominent technical area because of its location. The northern boundary of TA-54 is 4.8-km (3-miles) long and separates LANL from San Ildefonso Pueblo land. It also borders the town of White Rock. TA-54 consists of 120 buildings of which 101 contain waste management personnel and operations. Area $G$ expands over 25 ha (63 acres) on the 380 -ha ( 940 -acre) site. Waste management units within Area G include various LLW disposal pits and waste storage and disposal shafts (most of them closed), TRU waste pads and storage domes (may include LLW), a facility for 


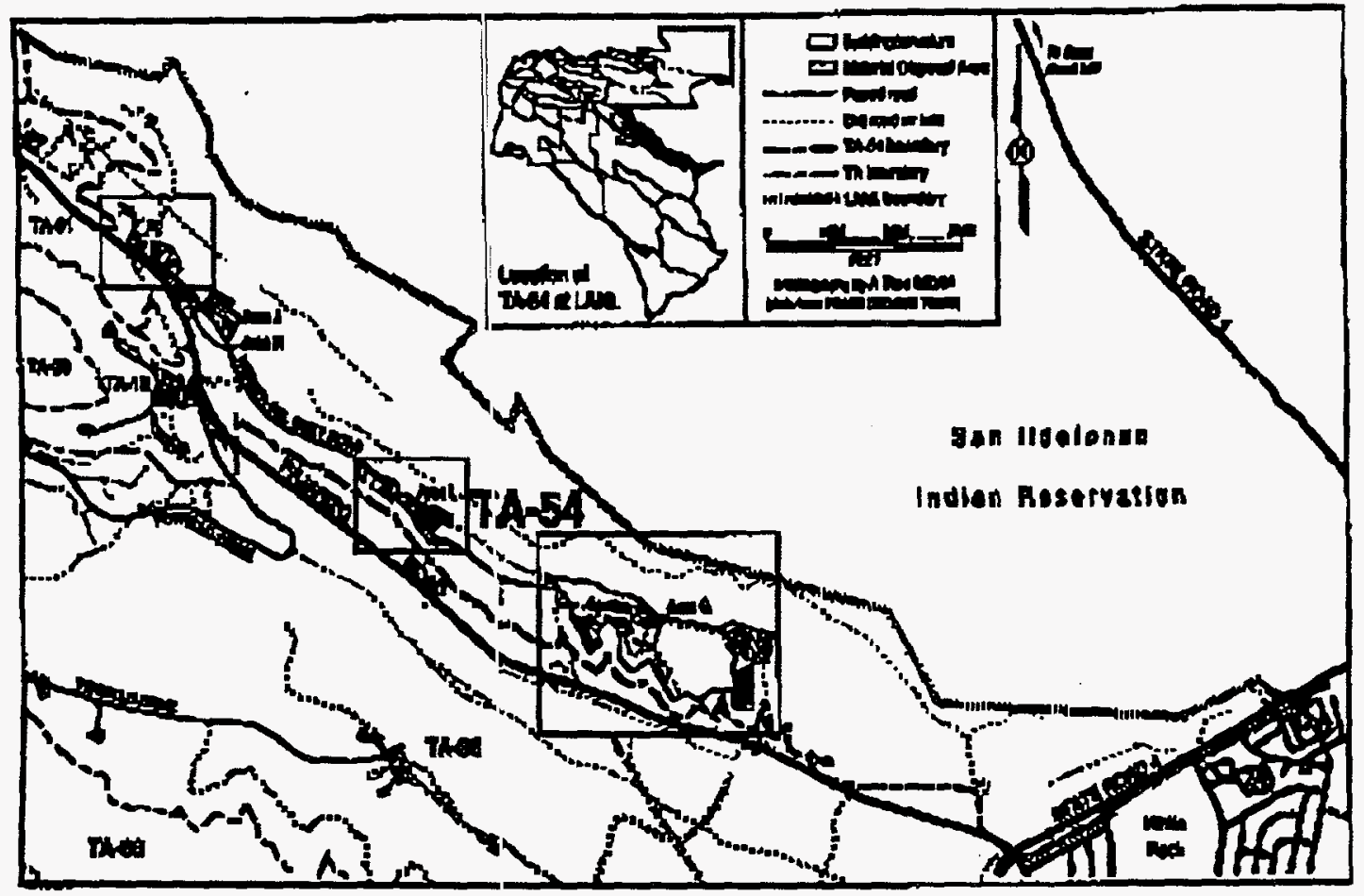

Fig. 7. TA-54.

decontaminating waste containers and contaminated equipment, two LLW compactor facilities, and an administrative support building that houses a locker room and decontamination shower. All of Area $G$ is considered to be a Hazard Category II Nuclear Facility. The facilities at TA-54 will be used for solid waste management.

Pajarito Road. Pajarito Road is owned and controlled by the U.S. Department of Energy (DOE). It connects the five aforementioned facilities. Any shipments of nuclear materials must be transported on this road. Because of the security and radiation risks of such shipments, this road is closed between the participating facilities when any such shipments occur. Thus, even though this road is generally open to the public, it may be closed by DOE at any time to accommodate hazardous or other materials requiring security or safety precautions. No modifications are expected for this facility to accommodate the LA fabrication effort.

\subsection{GENERAL FACILITY INFORVIATION NEEDS}

Environmental impact statements and environmental assessments that would have to be modified for LA fabrication activities include:

- DOE, Storage and Disposition of Weapons-Usable Fissile Materials Final Programmatic Environmental Impact Statement, DOE/EIS-0229, six volumes (December 1996).

- DOE, Final Programmatic Environmental Impact Statement for Stockpile Stewardship and Management, DOE/EIS-0236, four vclumes (September 1996).

- DOE, Environmental Assessment Radioactive Source Recovery Program, DOE/EA-1059 (December 20, 1995).

TA-55, which is the location of the PF, was comprised of 787 workers at the end of April $1997 . .^{3}$ During the LA fabrication process, it is istimated that a worker involved directly with fabrication would 
receive a dose of approximately $355 \mathrm{mrem}$ (assuming year-round operation). Table 3 shows the doses obtained by an average worker at TA-55 during the past 3 years. ${ }^{4}$

The LACEF, TA-18, is one of the proposed sites for the rod welding and assembly process. Approximately 117 workers ${ }^{5}$ are at TA-18, and the average dose to these workers ${ }^{4}$ is shown in Table 4 .

The CMR building in TA-3 is another of the proposed sites for rod welding and assembly process, and $\sim 350$ full-time workers are at the CMR building. ${ }^{6}$ The CMR building, TA-50, and TA-54 primarily consist of employees in the Chemistry Science and Technology (CST) Division of LANL. This division employs 757 workers ${ }^{7}$ as of the end of July 1997, and the average radiation dose received by these employees ${ }^{4}$ is shown in Table 5 .

\subsection{SPECIFIC FACILITIES INFORMATION NEEDS}

\subsubsection{Land Use}

Table 6 provides the latitude and longitude in NAD83 and the elevation in meters and feet above sea level of the various facilities discussed for fabrication activities at LANL.

\subsubsection{Air Quality}

The air emissions resulting from the LA fabrication process will be less than $1 \%$ of total emissions at PF-4 and an even smaller percentage of the overall laboratory air emissions.

Table 3. Doses to average TA-55 worker

\begin{tabular}{cccc}
\hline Year & $\begin{array}{c}\text { Dose to average } \\
\text { worker } \\
\text { (mrem) }\end{array}$ & $\begin{array}{c}\text { Dose to average } \\
\text { radiation worker } \\
\text { (mrem) }\end{array}$ & $\begin{array}{c}\text { Total dose } \\
\text { (person-rem) }\end{array}$ \\
\hline 1994 & 119 & 209 & 114 \\
1995 & 147 & 322 & 156 \\
1996 & 104 & 245 & 116 \\
\hline
\end{tabular}

Table 4. Doses to average TA-18 worker

\begin{tabular}{cccc}
\hline Year & $\begin{array}{c}\text { Dose to average } \\
\text { worker } \\
\text { (mrem) }\end{array}$ & $\begin{array}{c}\text { Dose to average } \\
\text { radiation worker } \\
\text { (mrem) }\end{array}$ & $\begin{array}{c}\text { Total dose } \\
\text { (person-rem) }\end{array}$ \\
\hline 1994 & 2 & 9 & 73 \\
1995 & 8 & 32 & 3472 \\
1996 & 6 & 27 & 2379 \\
\hline
\end{tabular}

Table 5. Doses to average CST worker

\begin{tabular}{cccc}
\hline Year & $\begin{array}{c}\text { Dose to average } \\
\text { worker } \\
\text { (mrem) }\end{array}$ & $\begin{array}{c}\text { Dose to average } \\
\text { radiation worker } \\
\text { (mrem) }\end{array}$ & $\begin{array}{c}\text { Total dose } \\
\text { (person-rem) }\end{array}$ \\
\hline 1994 & 2 & 15 & 220 \\
1995 & 3 & 20 & 366 \\
1996 & 4 & 23 & 387 \\
\hline
\end{tabular}


Table 6. Land use information

\begin{tabular}{|c|c|c|c|c|c|}
\hline $\begin{array}{l}\text { Requested } \\
\text { information }\end{array}$ & & & Facilities & & \\
\hline $\begin{array}{c}\text { Proposed facility } \\
\text { location }\end{array}$ & $\begin{array}{c}\text { TA-55 } \\
\text { PF-4 }\end{array}$ & $\begin{array}{l}\text { TA-18 } \\
\text { CMR }\end{array}$ & $\begin{array}{l}\text { TA-03 } \\
\text { CMR }\end{array}$ & $\begin{array}{l}\text { TA-50 } \\
50-01\end{array}$ & $\begin{array}{l}\text { TA-54 } \\
54-33 \\
\end{array}$ \\
\hline Latitude & 355149.3 & 355019.5 & 355217.4 & 355143.9 & 354956.5 \\
\hline Longitude & $-106 \quad 18 \quad 10.2$ & -1061611.6 & -1061920.5 & -1061753.3 & -1061426.8 \\
\hline $\begin{array}{l}\text { Elevation above } \\
\text { NGVD, }{ }^{a} \mathrm{~m}(\mathrm{ft})\end{array}$ & $2223(7292)$ & $2058(6752)$ & $2256(7400)$ & $2209(7249)$ & $2047(6716)$ \\
\hline
\end{tabular}

$a_{\text {National Geodetic Vertical Daturn. }}$

\subsubsection{Water}

No significant additional discharges to surface or groundwater would result from the LA fabrication process.

\subsubsection{Biological}

Several species covered by the Endangered Species Act are in the Los Alamos area. The species that have habitat or forage areas within $1.6 \mathrm{~km}$ (1 mile) of the potential facilities (TA-55, CMR, TA-18, TA-50, and Area $G$ in TA-54) include the southwestern willow fly catcher, American peregrine falcon, Arctic peregrine falcon, bald eagle, and Mexican spotted owl. Whooping cranes normally follow the Rio Grande flyway but are not usually found within $1.6 \mathrm{~km}$ of the facilities in question. The area is within the historic range of the black foot ferret; however, they have not been seen for a long time in this area. Map data are sensitive and cannot be released to protiect the species. Because the LA fabrication operations would take place in existing facilities and would tie a very small fraction of their use, there should be no adverse impacts on these species.

About 23 acres of wetlands exist near Area G in TA-54, across Pajarito Road in the canyon that runs parallel to the mesa. Some small pockets of wetlands in Mortandad Canyon are usually associated with National Pollutant Discharge Elimination System discharge locations. LA fabrication activities will have no impact on these locations.

\subsubsection{Infrastructure}

No significant additional resource uses will result from the LA fabrication activities.

\subsubsection{Waste Management}

Table 7 lists estimates of the amourt of solid TRU and solid and liquid LLW that is currently received by the waste management facilities at $L A N L$ each year. ${ }^{8}$ From previous MOX fuel fabrication activities in LANL's PF-4, it was estimated that about $0.62 \mathrm{~m}^{3}\left(22 \mathrm{ft}^{3}\right.$ ) of solid TRU waste (such as gloves and plastic bags), $4.8 \mathrm{~m}^{3}\left(170 \mathrm{ft}^{3}\right.$ ) of solid LLW (such as rags and gloves), and a negligible amount of liquid LLW would be produced annually from LA fabrication. By comparing these quantities to those in the table, it is noticeable that the contribution of waste resulting from LA fabrication would be minimal compared to the waste already processed at those facilit es. ${ }^{9}$ Thus, no additional waste management facilities would be required.

Table 7 illustrates that the presen: disposal facilities for LLW will be filled within the next 2 to 5 years and the laboratory must find another disposal site for all of its LLW. The amount generated in fabrication activities is extremely small compared to the amount of $L L W$ produced by the entire laboratory, so the laboratory needs to find a new disposal site whether or not LA fabrication occurs. No mixed TRU waste, LLMW, or hazardous waste should be produced from fabrication activities, and even if it were, no permit modifications for waste facilities vould be necessary. 
Table 7. Waste management information

\begin{tabular}{|c|c|c|c|c|c|c|}
\hline \multirow[b]{2}{*}{ Waste category } & \multirow[b]{2}{*}{$\begin{array}{l}\text { Current annual } \\
\text { generation } \\
\text { rate }\end{array}$} & \multirow[b]{2}{*}{$\begin{array}{l}\text { Amount } \\
\text { in } \\
\text { inventory }\end{array}$} & \multicolumn{4}{|c|}{ Available TSD facilities $^{a}$} \\
\hline & & & $\begin{array}{l}\text { Building } \\
\text { name }\end{array}$ & TSD method & Inventory & Capacity \\
\hline \multicolumn{7}{|l|}{ Transuranic } \\
\hline$(\mathrm{TRU})$ & N/A & N/A & N/A & N/A & N/A & N/A \\
\hline Liquid, L (gal) & 225 & 0 & TA-54 & Storage/ & 8700 & 24,000 \\
\hline Solid, $\mathrm{m}^{3}\left(\mathrm{ft}^{3}\right)$ & $(7900)$ & & Area G & certification & $(310,000)$ & $(850,000)$ \\
\hline \multicolumn{7}{|l|}{ Mixed TRU } \\
\hline Liquid, L (gal) & N/A & $\mathrm{N} / \mathrm{A}$ & N/A & N/A & N/A & N/A \\
\hline Solid, $\mathrm{m}^{3}\left(\mathrm{ft}^{3}\right)$ & N/A & N/A & N/A & N/A & N/A & N/A \\
\hline \multicolumn{7}{|l|}{ LLW } \\
\hline Liquid, L (gal) & $\begin{array}{c}20,400,000 \\
(5,400,000)\end{array}$ & 0 & $\begin{array}{l}\text { TA-50 } \\
\text { RLWTF }\end{array}$ & $\begin{array}{l}\text { Treatment/ } \\
\text { solidification }\end{array}$ & N/A & N/A \\
\hline Solid, $\mathrm{m}^{3}\left(\mathrm{ft}^{3}\right)$ & $\begin{array}{l}2000-4000 \\
(70-140,000)\end{array}$ & 0 & $\begin{array}{l}\text { TA-54 } \\
\text { Area G }\end{array}$ & $\begin{array}{l}\text { Compaction/ } \\
\text { disposal }\end{array}$ & $\begin{array}{l}250,000 \\
(8,800,000)\end{array}$ & $\begin{array}{l}252,500 \\
(8,900,000)\end{array}$ \\
\hline \multicolumn{7}{|l|}{ Mixed LLW } \\
\hline Liquid, L (gal) & N/A & N/A & $\mathrm{N} / \mathrm{A}$ & N/A & N/A & N/A \\
\hline Solid, $\mathrm{m}^{3}\left(\mathrm{ft}^{3}\right)$ & N/A & N/A & N/A & N/A & N/A & N/A \\
\hline \multicolumn{7}{|l|}{ Hazardous } \\
\hline Liquid, L (gal) & N/A & N/A & N/A & N/A & N/A & N/A \\
\hline Solid, $\mathrm{m}^{3}\left(\mathrm{ft}^{3}\right)$ & N/A & N/A & N/A & N/A & N/A & N/A \\
\hline \multicolumn{7}{|l|}{$\begin{array}{l}\text { Nonhazardous } \\
\text { (sanitary) }\end{array}$} \\
\hline Liquid, L (gal) & N/A & N/A & N/A & N/A & N/A & N/A \\
\hline Solid, $\mathrm{m}^{3}\left(\mathrm{ft}^{3}\right)$ & N/A & N/A & N/A & N/A & N/A & N/A \\
\hline \multicolumn{7}{|l|}{$\begin{array}{l}\text { Nonhazardous } \\
\text { (other) }\end{array}$} \\
\hline Liquid, L (gal) & N/A & N/A & N/A & N/A & N/A & N/A \\
\hline Solid, $\mathrm{m}^{3}\left(\mathrm{ft}^{3}\right)$ & N/A & N/A & N/A & N/A & N/A & N/A \\
\hline
\end{tabular}

$a_{\mathrm{TSD}}=$ treatment, storage, and/or disposal.

\section{REFERENCES}

1. Personal communication from J. F. Vanhecke, Jr., Los Alamos National Laboratory (HR-3-HRIS), to Oak Ridge National Laboratory, August 11, 1997.

2. Personal communication from B. B. Bates, Jr., Los Alamos National Laboratory (ESH-12), to Oak Ridge National Laboratory, August 12, 1997.

3. Personal communication from N. Teague, HR-5-STAFF, to Oak Ridge National Laboratory, August 13, 1997.

4. Personal communication from B. B. Bates, Jr., Los Alamos National Laboratory (ESH-12), to Oak Ridge National Laboratory, August 13, 1997.

5. World Wide Web site at http://nis-www.lanl.gov/cgi-bin/finger.sst?group=NIS-6.

6. Personal communication from M. Lujan, Los Alamos National Laboratory (CST-26/CON), to Oak Ridge National Laboratory, August 14, 1997.

7. Personal communication from J. F. Vanhecke, Jr., Los Alamos National Laboratory (HR-3-HRIS), to Oak Ridge National Laboratory, August 15, 1997. 
8. Information was obtained from World Wide Web site at http://wmgt.lanl.gov/background2.html; Personal communication from D. V. Christensen and A. I-Li Chen, Los Alamos National Laboratory (EMSWO), to Oak Ridge National Laboratory, August 15, 1997; and DOE, Final Programmatic Environmental Impact Statement for Stockpile Stewaraship and Management, DOE/EIS-0236, Sept. 1996, 70.

9. Personal communication from K. Chidester, Los Alamos National Laboratory (NMT-9), to Oak Ridge National Laboratory, June 27, 1997. 


\section{LA-UR-98-236 \\ December 1997}

\section{ENVIRONMENTAL IMPACT STATEMENT DATA REPORT FOR THE SURPLUS PLUTONIUM DISPOSITION MIXED OXIDE FUEL LEAD ASSEMBLY FABRICATION PROJECT AT LOS ALAMOS NATIONAL LABORATORY}

John J. Buksa, Stacey L. Eaton, and Holly R. Trellue

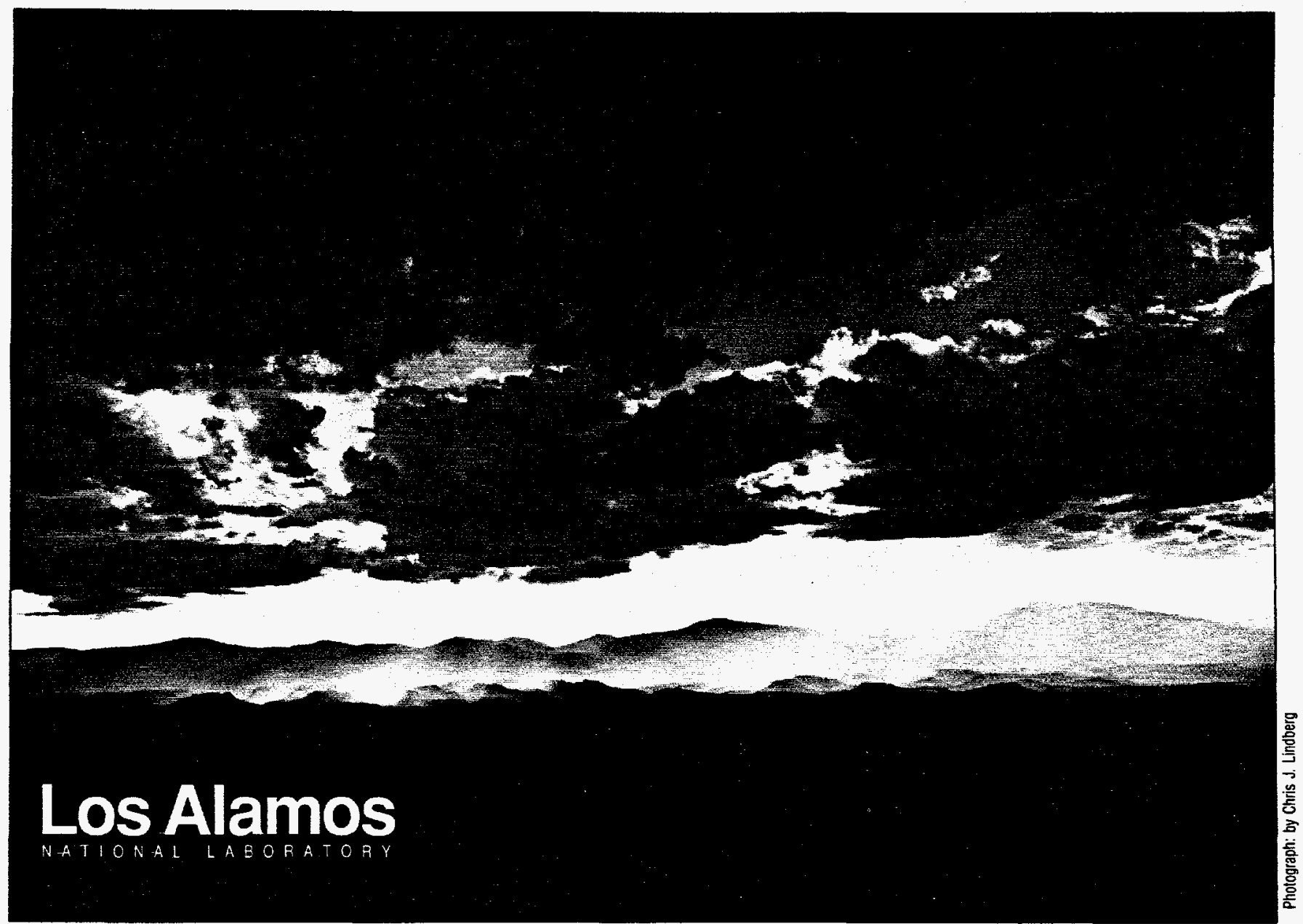

Los Alamos National Laboratory, an affirmative action/equal opportunity employer, is operated by the University of California for the U.S. Department of Energy under contract W-7405-ENG-36. By acceptance of this article, the publisher recognizes that the U.S. Government retains a nonexclusive, royalty-free license to publish or reproduce the published form of this contribution, or to allow others to do so, for U.S. Government purposes. The Los Alamos National Laboratory requests that the publisher identify this article
as wort performed under the auspices of the U.S. Deparment of Energy. Los Alamos National Laboratory strongly supports academic freedom and a researcher's right to publish; therefore, the Laboratory as an institution does not endorse the viewpoint of a publication or guarantee its technical correctmess. 
TILE: Environmental Impact Statement Data Report for the Surplus Plutonium Disposition Mixed Oxide Fuel Lead Assembly Fabrication Project at Los Alamos National Laboratory

SUBMITRE TO: General Distribution 
Environmental Impact Statement Data Report for the Surplus Plutonium Disposition Mixed Oxide Fuel Lead Assembly Fabrication Project at Los Alamos National Laboratory

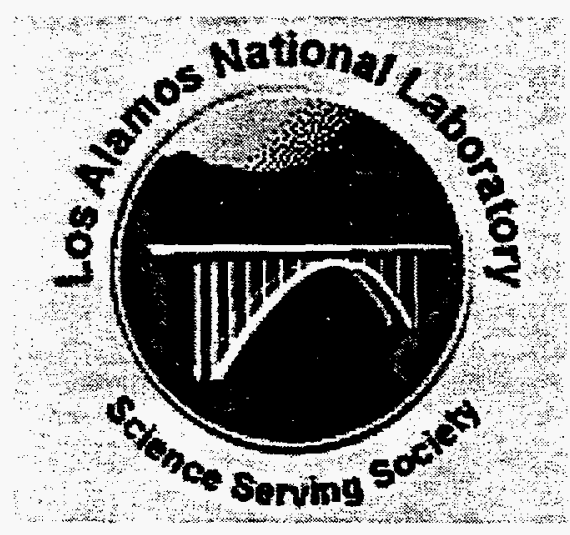

December 15, 1997 


\title{
Environmental Impact Statement Data Report for the Surplus Plutonium Disposition Mixed Oxide Fuel Lead Assembly Fabrication Project at Los Alamos National Laboratory
}

\author{
J. J. Buksa, S. L. Eaton, and H. R. Trellue
}

\subsection{General Site Data Needs}

Los Alamos National Laboratory (LANL) is a multiprogram laboratory with the central mission of reducing the nuclear danger. In the past, this mission primarily included nuclear weapons research, development, and testing, but it has recently expanded into the following areas:

- stockpile stewardship activities

- stockpile support projects

- nuclear materials management

- effective nonproliferation and counterproliferation technologies

- cleaning up the legacy of fifty years of weapons production

LANL also continues its involvement in defense activities, such as nuclear weapons technology and civilian problems, including health, national infrastructure, energy, education, and environment.

The latest available annual site environmental monitoring report is titled Environmental Surveillance at Los Alamos during 1995 (LA-13210-ENV). It can be found by accessing the World Wide Web at the address:

//lib-www.lanl.gov/la-pubs/00326112.pdf (p. i-xix, 1-146) and http://lib-www.lanl.gov/lapubs/00326113.pdf (p. 147-300).

At the end of July 1997, LANL consisted of 8,466 University of California employees and 1,079 contractors, for a total of 9,545 workers. ${ }^{1}$ Table 1-1 shows the doses obtained by a worker at LANL over the past three years. ${ }^{2}$

The mixed oxide (MOX) lead assembly (LA) fabrication activities at LANL will primarily take place at the plutonium facility (PF-4), which is located in Technical Area (TA)-55. Air emissions resulting from these activities would contribute to less than one percent of the total air emissions from PF-4, which is an insignificant amount compared with the total amount of air emissions released from the entire laboratory. Furthermore, current MOX fuel fabrication activities at PF-4

Table 1-1. Doses to the Average LANL Worker

\begin{tabular}{|c|c|c|c|}
\hline Year & $\begin{array}{c}\text { Dose to Average } \\
\text { Worker (mrem) }\end{array}$ & $\begin{array}{c}\text { Dose to Average } \\
\text { Rad Worker (mrem) }\end{array}$ & $\begin{array}{c}\text { Total Dose } \\
\text { (person-rem) }\end{array}$ \\
\hline 1994 & 15 & 75 & 178 \\
1995 & 18 & 88 & 235 \\
1996 & 16 & 91 & 180 \\
\hline
\end{tabular}

\footnotetext{
${ }^{1}$ Personal communications with J. F. Vanhecke, Jr. of LANL group HR-3-HRIS, August 11, 1997.

${ }^{2}$ Personal communications with Bob B. Bates, Jr. of LANL group ESH-12, August 12, 1997.
} 
also contribute to workers' doses, employment, air emissions, water discharges, and waste generation rates presented in this document. LA fabrication would consequently have even less of an impact than estimated here.

Both $r$ inority and low-income $r$ opulations live in Los Alamos and the surrounding areas, but no additional environmental effects on these populations should occur because there are no significant environmental consequences for LA fabrication. Thus, no environmental justice issues or activities are associated with the site.

\subsection{Location Specific Data Needs}

The lead assembly fabrication effort at Los Alamos National Laboratory (LANL) is proposed to take place at several different facilities, each of which are specially designed and equipped to handle different steps of the process. The fuel fabrication and rod loading/welding would be performed at TA-55, more specifically in building four of PF-4. The bundle assembly and inspection could be performed at any one of a number of facilities, including the Radioactive Materials Research, Operations, and Demonstration (RAMROD) Facility at TA-50, the Chemistry and Metallurgy Research (CMR) Building at TA-3, or one of the Critical Assembly Building Kivas at TA-18. Bundle storage is proposed to occur in the basement area of PF-4, and from there the bundles would be be loaded onto safe/secure transport (SST) vehicles for transport off site. These and other facilities of interest (i.e., waste-handling facilities) are listed below, and Table 2-1 summarizes the functions proposed for each facility. Their locations with respect to other laboratory areas and the towns of Los Alamos and White Rock can be seen in Fig. 2-1.

\section{TA-55/PF-4}

TA-55, the plutonium facility complex, is one of the larger technical areas at LANL. The facilities at TA-55 are located on a 16-hectire (40-acre) site about $1.6 \mathrm{~km}$ (one mile) southeast of TA-3. The primary research and development facility at TA-55 is the Plutonium Facility. All plutonium entering or exiting TA-55 is processed at this facility, which is a two-story laboratory with a surface area of $-14,000 \mathrm{~m}^{2}\left(151,000 \mathrm{ft}^{2}\right)$. The main complex has five connected buildings (see Fig. 2-2): Administration Building, (PF-1), Support Office Building (PF-2), Support Building (PF3), Plutonium Facility (PF-4), and Warehouse (PF-5). PF-4 is classified as a Safeguards Category 1 and a Hazard Category 2 nonreactor nuclear facility and was built to comply with

Table 2-1. Potential Functions for Each Facility

\begin{tabular}{|l|c|c|c|c|c|c|c|}
\hline Facility & $\begin{array}{c}\text { Pellet } \\
\text { Fabri- } \\
\text { cation }\end{array}$ & $\begin{array}{c}\text { Rocl } \\
\text { Fabr- } \\
\text { cation }\end{array}$ & $\begin{array}{c}\text { Bundle } \\
\text { Assembly }\end{array}$ & $\begin{array}{c}\text { Analytical } \\
\text { Chemistry }\end{array}$ & $\begin{array}{c}\text { Waste } \\
\text { Manage- } \\
\text { ment }\end{array}$ & $\begin{array}{c}\text { Bundle } \\
\text { Storage }\end{array}$ & $\begin{array}{c}\text { Trans- } \\
\text { portation }\end{array}$ \\
\hline TA-55/PF-4 & $\mathrm{X}$ & $\mathrm{X}$ & $\mathrm{X}$ & $\mathrm{X}$ & & $\mathrm{X}$ & \\
\hline TA-3/CMR & & & $\mathrm{X}$ & $\mathrm{X}$ & & $\mathrm{X}$ & \\
\hline TA-18/Kivas & & & $\mathrm{X}$ & & & $\mathrm{X}$ & \\
\hline $\begin{array}{l}\text { TA-50 } \\
\text { RAMROD }\end{array}$ & & & $\mathrm{X}$ & & & $\mathrm{X}$ & \\
\hline $\begin{array}{l}\text { TA-54, } \\
\text { TA-50 }\end{array}$ & & & & & $\mathrm{X}$ & & \\
\hline $\begin{array}{l}\text { Pajarito } \\
\text { Road }\end{array}$ & & & & & & & $\mathrm{X}$ \\
\hline
\end{tabular}




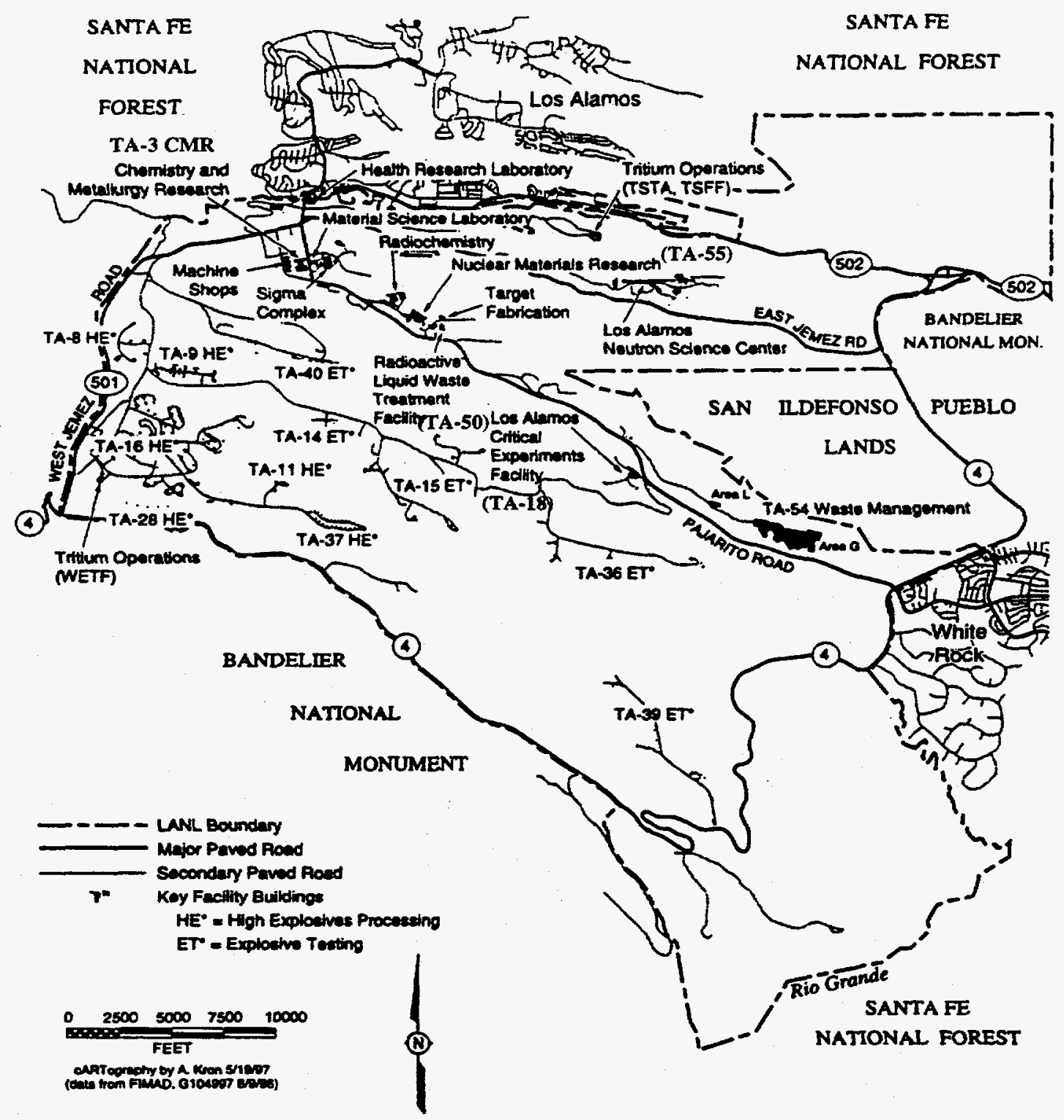

Fig. 2-1. Locations of LANL technical areas.

seismic standards for Safeguards Category 1 buildings. The ventilation system in the facility has four zones. The overall design concept for PF-4 separates the building into two halves. Each half operates as a separate building with its own filtered exhaust stack. Various ongoing activities at the Plutonium Facility include: plutonium recovery, fabrication of plutonium components, disassembly of weapons components, actinide processing, research and development, processing of ${ }^{238} \mathrm{Pu}$, and especially the fabrication of ceramic-based reactor fuels.

For the lead assembly fabrication effort, most of the activities are proposed to occur within PF-4. The operational fuel fabrication laboratories (Rooms 125 and 126) will be used with minor modifications to fabricate the lead assembly fuel. Already planned upgrades to Room 124 (next 


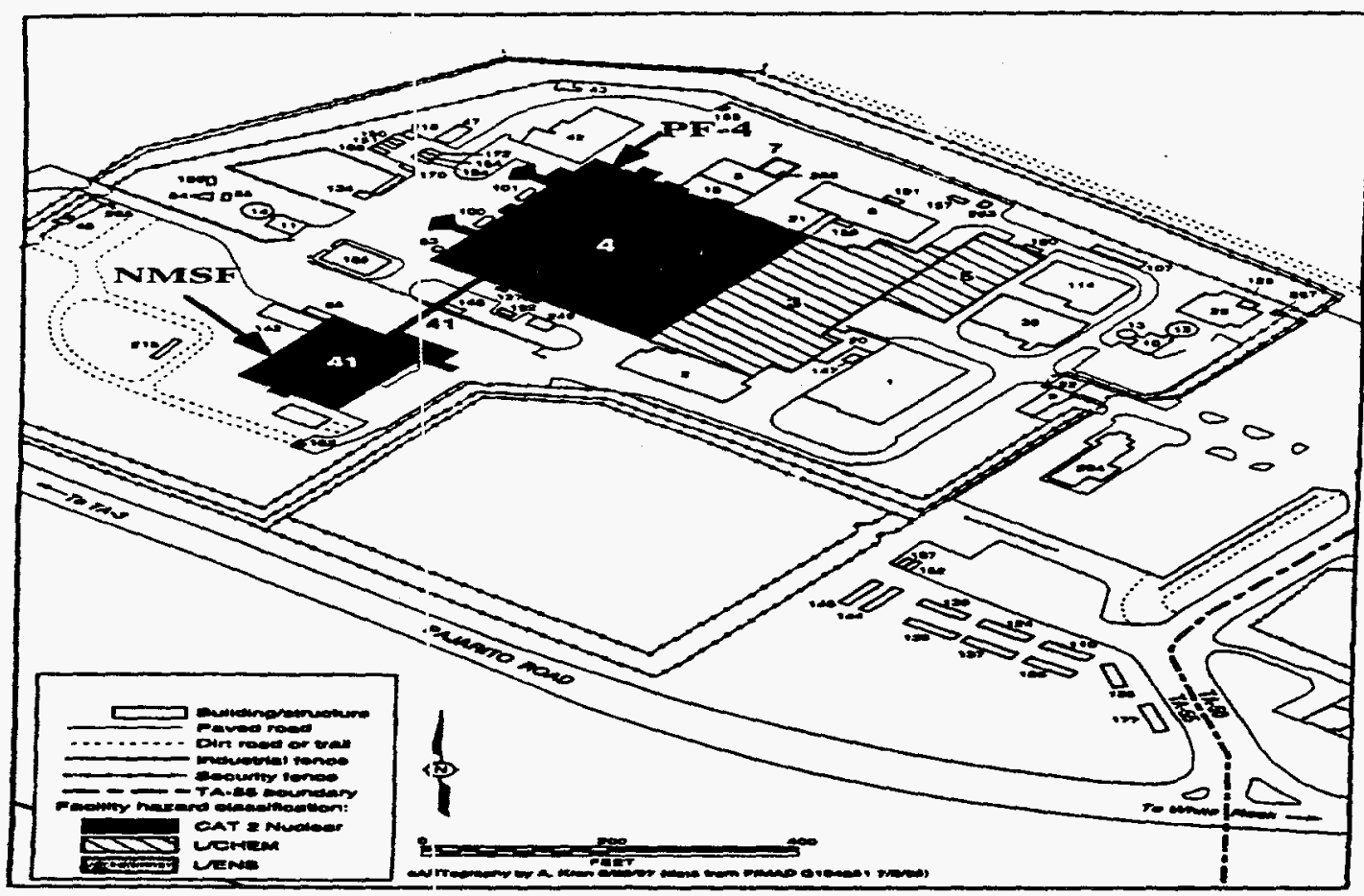

Fig. 2-2. Facilities at Technical Area 55.

door to the fuel fabrication laboratories) could provide on-site analytical chemistry capability for the lead assembly fabrication effort. It is most likely, however, that the majority of the analytical chemistry activities will take place in the already operational laboratories within the CMR Facility. The rod loading and welding activities are also proposed for PF-4, in Room 201. Although the bundle assembly is proposed to take place elsewhere (i.e., RAMROD, CMR), it is assumed that the bundle storage could be done in PF-4, most likely in the basement area.

\section{TA-3/CMR Building}

TA-3 (see Fig. 2-3) is LANL's main and largest technical area, both in terms of the amount of land space and the number of personnel. It houses a variety of projects and contains a number of buildings/facilities, including the CMR Building (see Fig. 2-4). This building was designed within TA-3 as an actinide chemistry and metallurgy research facility. The main corridor contains seven wings that were constructed in 1952. In 1960, a new wing (Wing 9) was added for activities that must be performed in hot cells. The three-story building now has eight wings connected by a spinal corridor and contains a total of $51,000 \mathrm{~m}^{2}\left(550,000 \mathrm{ft}^{2}\right)$ of space. Each wing is associated with different activities. Containing hot cells and Special Nuclear Material (SNM) vaults, it now is the only LANL facility with full capabilities for performing SNM analytical chemistry and materials science in support of the nuclear weapons program. It is currently designated as a Safeguards Category 3 and Hazard Category 2 nuclear facility, with some Safeguards Category 1 capabilities.

The CMR Facility hosts a variety of activities, principally: analytical chemistry, uranium processing, destructive and nondestructive analysis, actinide research and processing, fabrication, and metallography. Enough waste treatment and pretreatment are conducted within the facility to sufficiently meet waste acceptance criteria for both on- and off-site receiving facilities. In addition to being the primary location for many projects, these facilities are used to support various activities at other LANL locations. 
Analytical chemistry capabilities involving the study, evaluation, and analysis of radioactive materials also reside at the CMR Building. These activities support various nuclear materials programs, many of which are performed at other LANL locations. Analytical activities include assay and determination of isotopic ratios of plutonium, uranium, and othe- actinides; major and trace elements in the materials; interstitial gases analysis; highly sensitive surface analysis techniques; and methods to determine environmentally important waste constituents on highly radioactive materials.

The high bay in Wing 9 of the CMR building is the area proposed for the assembly of bundles and bundle inspection. Bundle storage might be an option in the CMR Facility, but it will most likely be restricted to a temporary basis while bundles are awaiting transport to PF-4. The CMR Facilities will also most likely be the location of much of the analytical chemistry activities for this project.

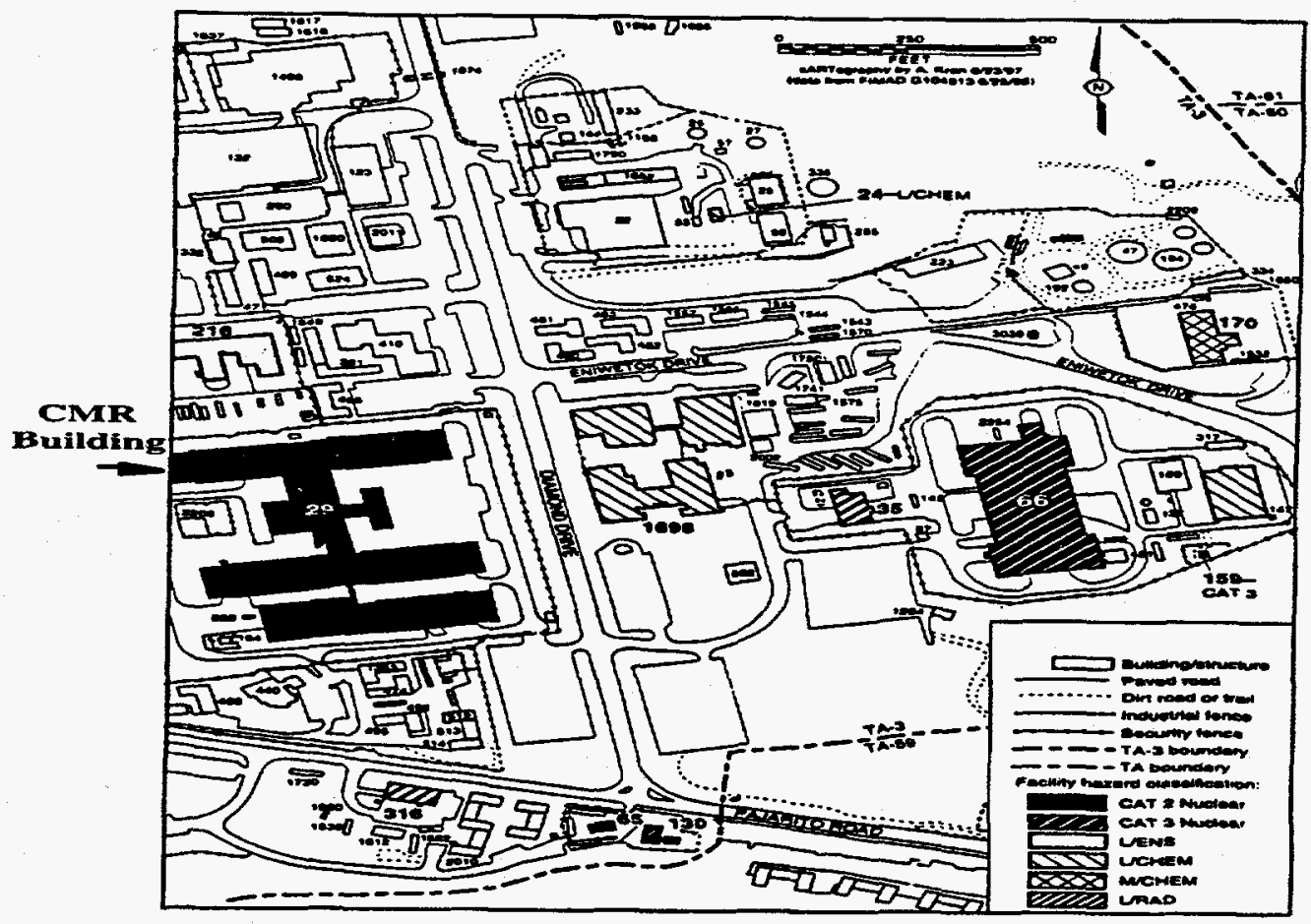

Fig. 2-3. Facilities in TA-3. 


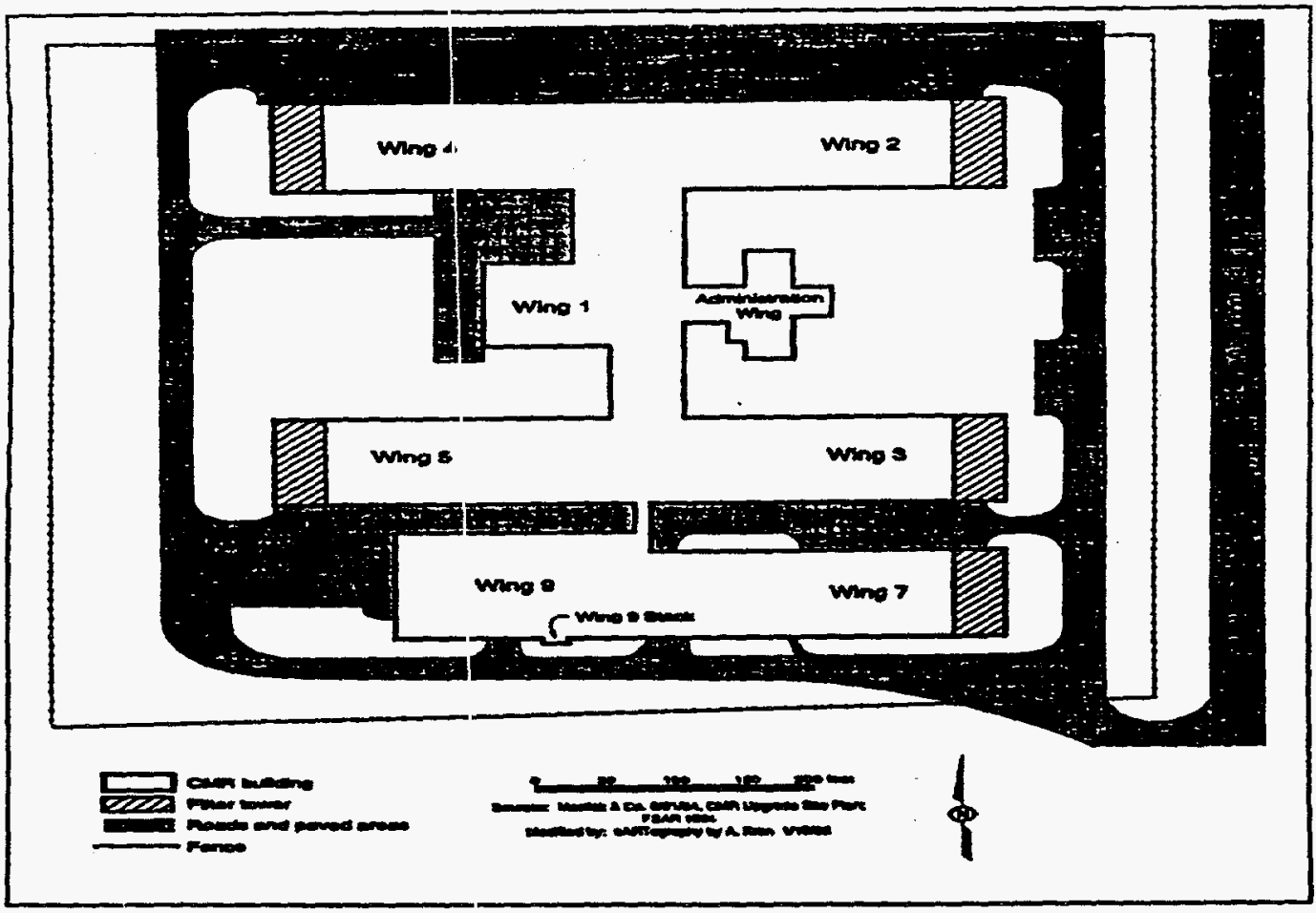

Fig. 2-4. CMR building layout.

\section{TA-18}

Another facility being considered for the assembly of fuel rods into bundles is the Los Alamos Critical Experiments Facility (LACEF), or TA-18, which is located in arid Pajarito Canyon about $6.4 \mathrm{~km}$ (4 miles) southeast of TA-3 on Pajarito Road (see Section 2.6). LACEF has operated since 1946 and is one of the last general-purpose nuclear experimental facilities in the United States. Its activities include: national security programs, such as the Nuclear Emergency Search Team (NEST), Strategic Defense Initiative research, Strategic Arms Reduction Treaty verification research, and the development of: instrumentation for nuclear waste assay and high-explosives detection. The current primary purposes of LACEF are the design, construction, research, development, and application of critical experiments, as well as teaching and training criticality safety and other applications of radiation detection and instrumentation. TA-18 is a restricted area containing many security fences and extra layers of security and safeguard protection. Four buildings within TA-18 are Hazard Category 3 Nuclear Facilities, and these include the Critical Assembly Buildings Kivas \#1, \#2, \#3 (see Fig. 2-5), and the Hillside Vault. These three Kivas are also classified as Safeguards Category I. Each of these kivas is surrounded by security fences and additional security and safeguard precautions. Each kiva has metal lockers used to store spent nuclear fuel containers: load limits are placed on the vaults. These vaults can only be accessed from the entrance to the kiva. Kiva \#1 is $134 \mathrm{~m}^{2}\left(1,440 \mathrm{ft}^{2}\right)$ in area, Kiva \#2 is about $162 \mathrm{~m}^{2}$ $\left(1,740 \mathrm{ft}^{2}\right)$, and Kiva \#3 has an area of approximately $482 \mathrm{~m}^{2}\left(5,184 \mathrm{ft}^{2}\right)$. Kiva \#3 contains the most shielding of the three because it is located closest to occupied buildings, while Kivas \#1 and \#2 do not require as much shielding, because they are located farther away. It is proposed that one of these kivas may be used to assemble and inspect fuel bundles for the lead assemblies. 


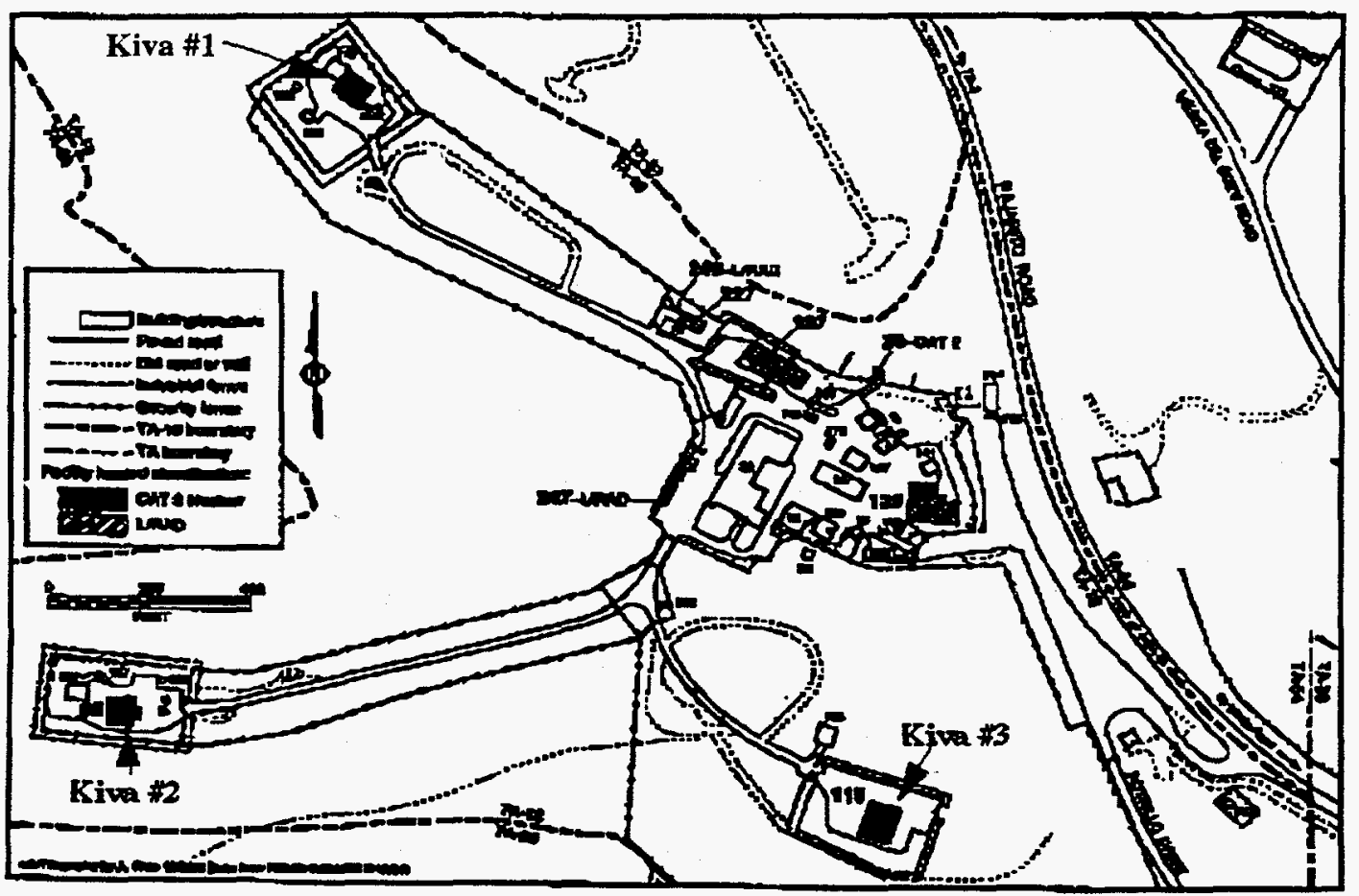

Fig. 2-5. Facilities at Technical Area 18.

\section{TA-50}

TA-50 is a Laboratory Waste Management Site located near the center of LANL. It exists on 25 hectares ( 62 acres) of land, which includes 33 waste management structures such as trailers, tanks, and storage sheds, as well as four buildings (see Fig. 2-6). The facilities at TA-50 will be used for the liquid waste management functions of this project. The RAMROD building is also a candidate facility for the bundle assembly and inspection activities. The following waste activities take place at TA-50: radioactive liquid waste treatment; decontamination of respirators, equipment, instruments, vehicles, and other waste items: size reduction of transuranic wastes; and characterization of TRU. The facilities are capable of storing and disposing of both solid and liquid low-level radioactive waste, low-level mixed waste, TRU, and hazardous waste. Major facilities at the area include: the Radioactive Liquid Waste Treatment Facility (RLWTF), the Waste Characterization, Reduction, and Repackaging Facility (WCRRF), and the RAMROD Facility.

Special lines and a concrete vault exist to allow acid and caustic radioactive liquid wastes from TA55 , which contain relatively high amounts of americium and plutonium, to be treated and pretreated at TA-50. The aqueous waste from radioactive activities and other nonhazardous aqueous chemical wastes at the CMR Facility are also discharged into a network of drains and transported to TA-50 for treatment and disposal. The small amount of liquid wastes resulting from chemical analyses on plutonium, uranium, and MOX fuel samples are put in bottles and shipped to TA-55 where they eventually enter the liquid waste stream to TA-50.

Once wastes are treated, they are packaged to be transported to TA-54 (see next section) for disposal (low-level waste) or retrievable storage (TRU) until they can be shipped to a long-term storage facility. Two buildings in TA-50 are designated as Hazard Category 2 Nuclear Facilities. 


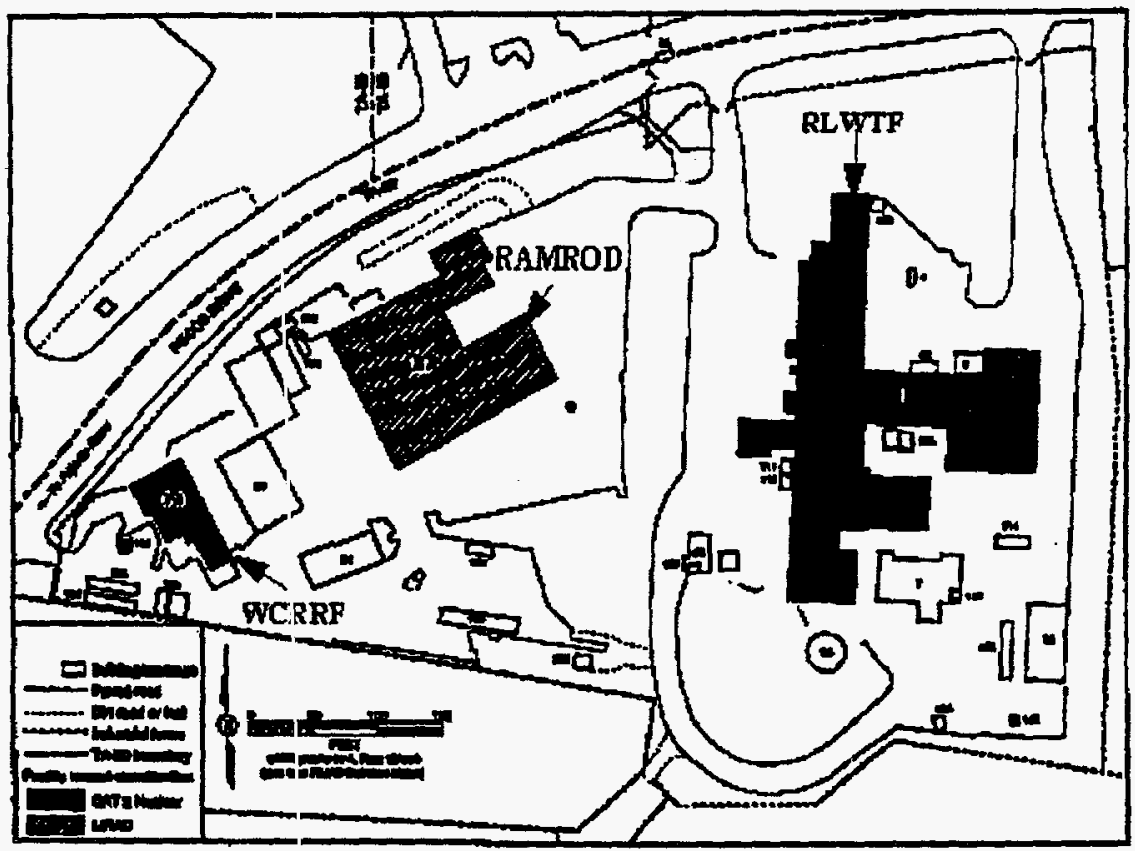

Fig. 2-6. Facilities at Technical Area 50.

These are the RLWTF and the WCRRF. The RLWTF is the building to which the acid and caustic wastes generated at TA-55 are transported. The WCRRF building is where TRU wastes are packaged to be transported to TA.54. The RAMROD facility is also a candidate Hazard Category 2 Nuclear Facility; however. instead it currently performs combustion-based volume reduction and chemical stabilization of TRU-corttaminated solid wastes and polychlorinated biphenyls (PCBs) as well as other waste streams.

\section{TA-54}

Also, one of the largest laboratory facilities, TA-54, is the main location for solid radioactive and hazardous chemical waste management and disposal. It has been active since 1957 and is predicted to remain open in the future. The facilities in TA-54 are grouped into various designated regions including Areas G, H, J, and L (see Fig. 2-7). Area $G$ is the $L L W$ management area. Area $H$ is a Resource Conservation and Recovery Act site previously used to dispose radioactive wastes (until 1986), Area $J$ is a classified solid and nonhazardous waste management site, and Area $L$ is the location of chemical waste management activities. Area $G$ is the area that will be used to handle wastes after MOX fuel fabrication. It is here that the solid LLW and TRU wastes typically packaged at TA-55 or TA-50 will be shipped. 


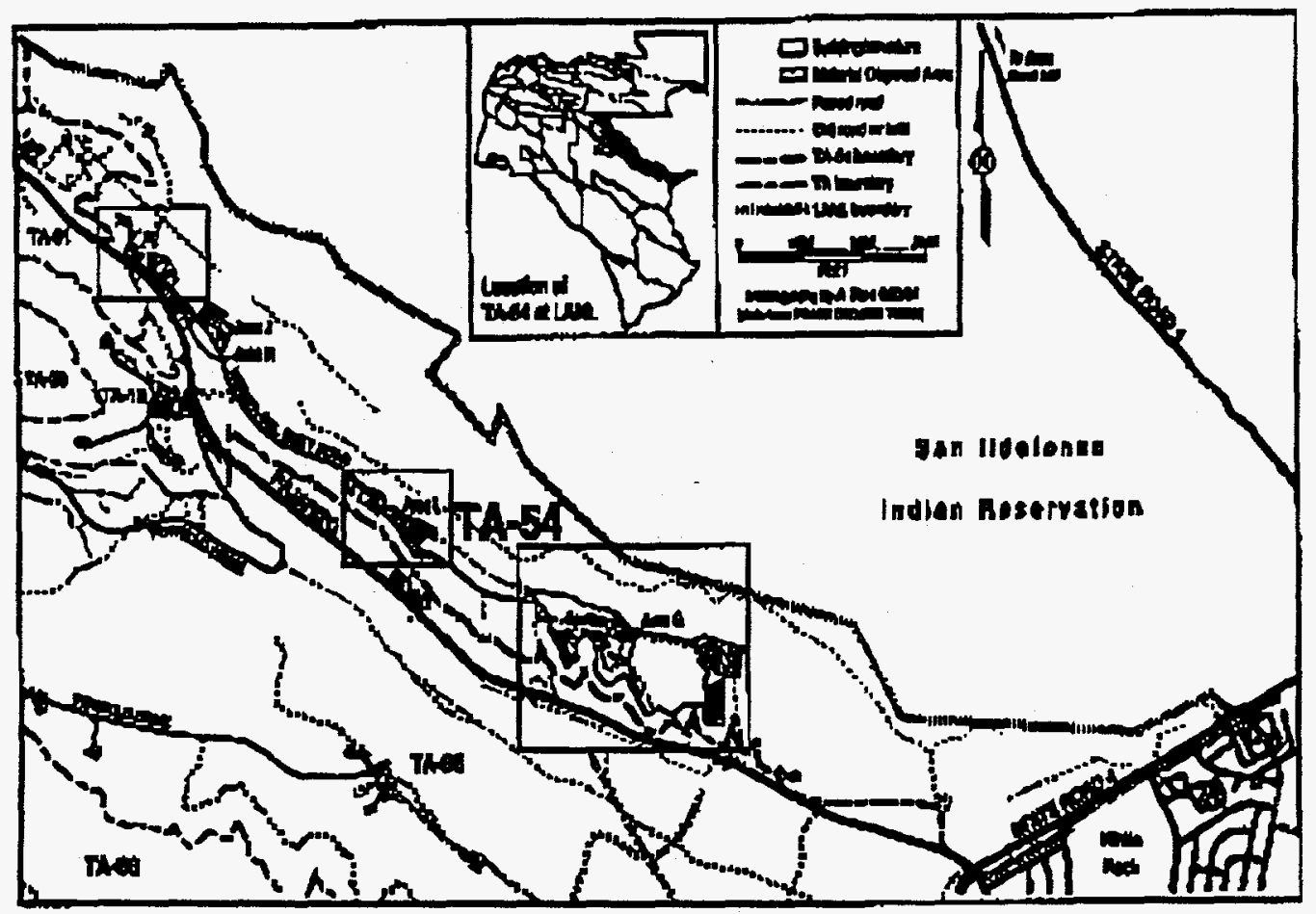

Fig. 2-7. Technical Area 54.

TA-54 is considered to be an environmentally prominent technical area because of its location. The northern boundary of TA-54 is $4.8 \mathrm{~km}$ ( 3 miles) long and separates the Laboratory from San Ildefonso Pueblo land. It also borders the town of White Rock. TA-54 consists of 120 buildings of which 101 contain waste management personnel and operations. Area G expands over 25 hectares (63 acres) on the 380-hectare (940-acre) site of TA-54. Waste management units within Area $G$ include various LLW disposal pits and waste storage and disposal shafts (most of them closed), TRU waste pads and storage domes (may include LLW), a facility for decontaminating waste containers and contaminated equipment, two LLW compactor facilities, and an administrative support building that houses a locker room and decontamination shower. All of Area $\mathrm{G}$ is considered to be a Hazard Category 2 Nuclear Facility. The facilities at TA-54 will be used for solid waste management.

\section{Pajarito Road}

This is a DOE owned and controlled roadway that connects the five aforementioned facilities. Any shipments of nuclear materials must be transported on this road. Because of the security and radiation risks of such shipments, this road is closed between the participating facilities when any such shipments occur. Thus, even though this road is generally open to the public, it may be closed by DOE at any time to accommodate hazardous or other materials requiring security or safety precautions. No modifications are expected for this facility to accommodate the lead assembly fabrication effort.

\subsection{General Facility Information}

Environmental Impact Statements and Environmental Assessments that would have to be modified for LA fabrication activities include 
- DOE, "Storage and Disposition of Weapons-Usable Fissile Materials Final Programmatic Environmental Impact Statement," DOE report DOE/EIS-0229, six volumes (December 1996).

- DOE, "Final Programmatic Environmental Impact Statement for Stockpile Stewardship and Management," DOE report DOE/EIS-0236, four volumes (September 1996).

- DOE, “Environmental Assessment Radioactive Source Recovery Program,” DOE report DOE/EA-1059 (December 20, 1995).

TA-55, which is the location of the plutonium facility, was comprised of 787 workers at the end of April 1997. ${ }^{3}$ During the LA fabrication process, it is estimated that a worker involved directly with fabrication would receive a dose of approximately $355 \mathrm{mrem}$ assuming year-round operation. Table 2.1-1 shows the doses obtained by an average worker at TA-55 over the past three years. ${ }^{4}$

TA-18 is one of the proposed sites for the rod welding and assembly process. There are approximately 117 workers $^{5}$ at T.A-18, and the average dose to these workers ${ }^{6}$ is shown in Table 2.1-2.

The CMR building in TA-3 is another of the proposed sites for rod welding and assembly process; there are approximately 350 full-time workers at the CMR Building. ${ }^{7}$ The CMR Building, TA-50, and TA-54 primarily consist of employees in the Chemistry Science and Technology (CST) Division of LANL. This division consisted of 757 employees $^{8}$ as of the end of July 1997, and the average radiation dose received by these employees ${ }^{9}$ is shown in Table 2.1-3.

Table 2.1-1. Doses to Average Worker in TA-55

\begin{tabular}{|c|c|c|c|}
\hline Year & $\begin{array}{c}\text { Dose to Average } \\
\text { Worker (mrem) }\end{array}$ & $\begin{array}{c}\text { Dose to Average } \\
\text { Rad Worker (mrem) }\end{array}$ & $\begin{array}{c}\text { Total Dose } \\
\text { (person-rem) }\end{array}$ \\
\hline 1994 & 119 & 209 & 114 \\
\hline 1995 & 147 & 322 & 156 \\
\hline 1996 & 104 & 245 & 116 \\
\hline
\end{tabular}

Table 2.1-2. Doses to Average Worker in TA-18

\begin{tabular}{|c|c|c|c|}
\hline Year & $\begin{array}{c}\text { Dose 1o Average } \\
\text { Worker (mrem) }\end{array}$ & $\begin{array}{c}\text { Dose to Average } \\
\text { Rad Worker (mrem) }\end{array}$ & $\begin{array}{c}\text { Total Dose } \\
\text { (person-rem) }\end{array}$ \\
\hline 1994 & 2 & 9 & 73 \\
\hline 1995 & 8 & 32 & 3472 \\
\hline 1996 & 6 & 27 & 2379 \\
\hline
\end{tabular}

\footnotetext{
${ }^{3}$ Personal communications with Nancy Teague of LANL group HR-5-STAFF, August 13, 1997.

${ }^{4}$ Personal communications with Bob B. Bates, Jr. of LANL group ESH-12, August 13, 1997.

${ }^{5}$ See World Wide Web site at http://nis-w'ww.lanl.gov/cgi-bin/finger.sst?group=NIS-6.

${ }^{6}$ Personal communications with Bob B. 33ates, Jr. of LANL group ESH-12, August 13, 1997.

${ }^{7}$ Personal communications with Marybeth Lujan of LANL group CST-26/CON, August 14, 1997.

${ }^{8}$ Personal communications with J. F. Vanhecke, Jr. of LANL group HR-3-HRIS, August 15, 1997.

${ }^{9}$ Personal communications with Bob B. Bates, Jr. of LANL group ESH-12, August 13, 1997.
} 
Table 2.1-3. Doses to Average CST Worker

\begin{tabular}{|c|c|c|c|}
\hline Year & $\begin{array}{c}\text { Dose to Average } \\
\text { Worker (mrem) }\end{array}$ & $\begin{array}{c}\text { Dose to Average } \\
\text { Rad Worker (mrem) }\end{array}$ & $\begin{array}{c}\text { Total Dose } \\
\text { (person-rem) }\end{array}$ \\
\hline 1994 & 2 & 15 & 220 \\
\hline 1995 & 3 & 20 & 36 \\
\hline 1996 & 4 & 23 & 38 \\
\hline
\end{tabular}

\subsection{Specific Facilities Information Needs}

2.2.1. Land Use

Table 2.2-1 provides the latitude and longitude in NAD83 and the elevation in meters and feet above sea level of the various facilities discussed for fabrication activities at LANL.

\subsubsection{Air}

The air emissions resulting from the LA fabrication process will be less than one percent of the total emissions at PF-4 and an even smaller percentage of the overall laboratory air emissions.

\subsubsection{Water}

No significant additional discharges to surface or groundwater would result from the LA fabrication process.

\subsubsection{Biological}

There are several species covered by the Endangered Species Act in the Los Alamos area. The species that have habitat or forage areas within $1.6 \mathrm{~km}$ (one mile) of the potential facilities (TA-55, CMR, TA-18, TA-50, and Area G in TA-54) include the south western willow fly catcher, American peregrine falcon, Arctic peregrine falcon, bald eagle, and the Mexican spotted owl. Whooping cranes normally follow the Rio Grande flyway but are not usually found within $1.6 \mathrm{~km}$ of the facilities in question. The area is within the historic range of the black foot ferret: however. they have not been seen for a long time in this part of the state. Map data is sensitive and cannot be released to protect the species. Since the LA fabrication operations would take place in existing facilities and would be a very small fraction of their use, there should be no adverse impacts on these species.

About 23 acres of wetlands occur near Area G in TA-54, across Pajarito Road in the canyon that runs parallel to the mesa. There are also some small pockets of wetlands in Mortandad Canyon that are usually associated with national pollutant discharge elimination system discharge locations. LA Fabrication activities will have no impact on these locations.

Table 2.2-1. Requested Information for Land Use

\begin{tabular}{|c|c|c|c|c|c|}
\hline $\begin{array}{c}\text { Requested } \\
\text { Information }\end{array}$ & & & Facilities & & \\
\hline Proposed & TA-55 & TA-18 & TA-03 & TA-50 & TA-54 \\
Facility Location & PF-4 & CMR & CMR & $50-01$ & $54-33$ \\
\hline Latitude & 355149.3 & 355019.5 & 355217.4 & 355143.9 & 354956.5 \\
\hline Longitude & -1061810.2 & -1061611.6 & -1061920.5 & -1061753.3 & -1061426.8 \\
\hline Elevation above & 2,223 & 2,058 & 2,256 & 2,209 & 20677 \\
NGVD, m (ft) & $(7,292)$ & $(6,752)$ & $(7,400)$ & $(7,249)$ & $(6,716)$ \\
\hline
\end{tabular}




\subsubsection{Infrastructure}

No significant additional resource uses will result from the LA fabrication activities.

\subsubsection{Waste Management}

Table 2.2.6-1 lists estimates of the amount of solid TRU and solid and liquid LLW that are currently received by the waste management facilities at LANL each year. ${ }^{10}$ From previous MOX fuel fabrication activities in PF-4, it was estimated that about $0.62 \mathrm{~m}^{3}\left(22 \mathrm{ft}^{3}\right)$ of solid TRU waste (such as gloves and plastic bags), $4.8 \mathrm{~m}^{3}\left(170 \mathrm{ft}^{3}\right.$ ) of solid LLW (such as rags and gloves), and a negligible amount of liquid LL.W would be produced annually from LA fabrication." ${ }^{11}$ By compring these quantities to those in the table, it is noticeable that the contribution of waste resulting from LA fabrication would be minimal compared with the waste already processed at those facilities. Thus, no additional waste management facilities would be required.

Table 2.2.6-1 shows that the present disposal facilities for LLW will be filled within the next two to five years, and the laboratory must find another disposal site for all of its LLW. The amount generated in fabrication activities is extremely small compared with the amount of LLW produced by the entire laboratory; therefore, the laboratory needs to find a new disposal site regardless of whether LA fabrication occurs or not. No mixed transuranic, mixed low-level, or hazardous waste should be produced from fabrication activities, and even if it were, no permit modifications for waste facilities would be necessary.

Table 2.2.6-1. Requested Information for Waste Management

\begin{tabular}{|c|c|c|c|c|c|c|}
\hline \multirow[t]{2}{*}{$=\frac{\overline{\text { Waste }}}{\text { Category }}$} & \multirow{2}{*}{$\begin{array}{c}\text { Current } \\
\text { Annual } \\
\text { Generation } \\
\text { Rate } \\
\end{array}$} & \multirow{2}{*}{$\begin{array}{l}\text { Amount } \\
\text { in } \\
\text { Inventory }\end{array}$} & & Available & $\begin{array}{c}\text { TSD } \\
\text { Facilities }\end{array}$ & \multirow[b]{2}{*}{ Capacity } \\
\hline & & & $\begin{array}{c}\text { Building } \\
\text { Name }\end{array}$ & TSD Method & Inventory & \\
\hline $\begin{array}{l}\text { Transuranic } \\
\text { (TRU) } \\
\text { Liquid, } 1\end{array}$ & N/A & N/A & N/A & N/A & N/A & N/A \\
\hline $\begin{array}{l}\text { Solid, } \mathrm{m}^{3} \\
\left(\mathrm{ft}^{3}\right)\end{array}$ & $\begin{array}{c}225 \\
(7,900)\end{array}$ & 0 & $\begin{array}{l}\text { TA-54 } \\
\text { Area G }\end{array}$ & $\begin{array}{c}\text { Storage/ } \\
\text { Certification }\end{array}$ & $\begin{array}{c}8,700 \\
(310,000)\end{array}$ & $\begin{array}{c}24,000 \\
(850,000)\end{array}$ \\
\hline $\begin{array}{l}\text { Mixed TRU } \\
\text { Liquid, I } \\
\text { (gal.) } \\
\text { Solid, } \mathrm{m}^{3} \\
\left(\mathrm{ft}^{3}\right)\end{array}$ & $\begin{array}{l}\text { N/A } \\
\text { N/A }\end{array}$ & $\begin{array}{l}\text { N/A } \\
\text { N/A }\end{array}$ & $\begin{array}{l}\text { N/A } \\
\text { N/A }\end{array}$ & $\begin{array}{l}\text { N/A } \\
\text { N/A }\end{array}$ & $\begin{array}{l}\text { N/A } \\
\text { N/A }\end{array}$ & $\begin{array}{l}\text { N/A } \\
\text { N/A }\end{array}$ \\
\hline
\end{tabular}

\footnotetext{
${ }^{10}$ Information was obtained from: World Wide Web site at http://wmgt.lanl.gov/background2.html, personal communications with Davis V. Christensen and Anita I-Li Chen of LANL group EM-SWO, August 15, 1997, and DOE, "Final Programmatic Environmental Impact Statement for Stockpile Stewardship and Management," DOE report DOE/EIS-0236, September 1996, p. 70.

${ }^{11}$ Personal communcations with Kennetr Chidester of LANL group NMT-9, June 27, 1997.
} 


\section{DOE PUBLIC READING ROOMS}

43. Albuquerque Operations Office, TV1 Community College Library, Montoya Campus, 4700 Morris, NE, Albuquerque, NM 87111.

44. Amarillo Area Office, U.S. Department of Energy, Amarillo College, Lynn Library/Learning Center, 2201 South Washington, P.O. Box 447, Amarillo, TX 79178.

45. U.S. DOE Reading Room, Carson County Library, 401 Main Street, P.O. Box 339, Panhandle, TX 79068.

46. Chicago Operations Office, Office of the Manager/Communications, U.S. Department of Energy, 9800 South Cass Avenue, Argonne, IL 60439.

47. Idaho National Engineering and Environmental Laboratory, Idaho Public Reading Room, 1776 Science Center Drive, Idaho Falls, ID 83402.

48. Los Alamos National Laboratory, U.S. Department of Energy, c/o Los Alamos Community Reading Room, 1350 Central, Suite 101, Los Alamos, NM 87544.

49. Nevada Operations Office, U.S. Department of Energy, Public Reading Room, 2621 Losse Road, North Las Vegas, NV 89030.

50. Oak Ridge Operations Office, U.S. Department of Energy, Public Reading Room, 200 Administration Road, Room G-217, Oak Ridge, TN 37831-8501.

51. Richland Operations Office, DOE Public Reading Room, 100 Sprout Road, Room 130 West, P.O. Box 999, M/S H2-53, Richland, WA 99352.

52. Rocky Flats Office, Front Range Community College Library, 3645 West 112th Avenue, Westminster, CO 80030.

53. Sandia National Laboratory/CA, Livermore Public Library, 1000 S. Livermore Avenue, Livermore, CA 94550.

54. Savannah River Operations Office, Gregg-Graniteville Library, University of South Carolina-Aiken, 171 University Parkway, Aiken, SC 29801.

55. U.S. Department of Energy, Freedom of Information/Privacy Act Public Reading Room, Forrestal Building, Room 1E-190, 1000 Independence Avenue SW, Washington, DC 20585. 
ORNL/TM-13466

\section{INTERNAL DISTRIBUTION}

\author{
1. J. J. Carbajo \\ 2. B. S. Cowell \\ 3. S. E. Fisher \\ 4. E. C. Fox \\ 5. R. G. Gilliland \\ 6. S. R. Greene \\ 7. S. A. Hodge \\ 8. R. Holdaway \\ 9. S. B. Ludwig \\ 10. G. T. Mays \\ 11. K. L. McElhaney \\ 12. G. E. Michaels \\ 13. R. N. Morris
}

14. D. L. Moses

15. D. G. O'Connor

16. R. T. Primm III

17. R. R. Rahn

18. J. D. Sease

19. C. C. Southmayd

20. V.S. White

21. C. K. Williams

22. D. L. Williams, Jr.

23. Central Research Library

24-25. ORNL Laboratory Records (OSTI)

26. ORNL Laboratory Records-RC

\section{EXTERNAL DISTRIBUTION}

27. M. J. Barr, Los Alamos National Laboratory, P.O. Box 1663, MS-E583, Los Alamos, NM 87545

28. J. J. Buksa, Los Alamos National Laboratory, P.O. Box 1663, MS-K551, Los Alamos, NM 87545

29. H. R. Canter, U.S. Departraent of Energy, MD-3, 1000 Independence Avenue SW, Washington, DC 20585.

30. S. L. Eaton, Los Alamos National Laboratory, P.O. Box 1663, MS-K551, Los Alamos, NM 87545

31. J. Eichner, Science Applications International Corp., 20201 Century Blvd., Germantown, MD 20874.

32. K. Gandee, U.S. Department of Energy, MD-4, 1000 Independence Avenue SW, Washington, DC 20585.

33. C. Groome, Science Applications International Corp., 20201 Century Blvd., Germantown, MD 20874.

34. D. Hirrlinger, Science Applications International Corp., 20201 Century Blvd., Germantown, MD 20874.

35. J. V. Johnson, U.S. Departunent of Energy, MD-4, 1000 Independence Avenue SW, Washington, DC 20585.

36. D. J. Nulton, U.S. Department of Energy, MD-4, 1000 Independence Avenue SW, Forrestal Bldg., Room 6G-050, Washington, DC 20585.

37. D. Peko, U.S. Department of Energy, MD-3, 1000 Independence Avenue SW, Washington, DC 20585.

38. P. T. Rhoads, U.S. Department of Energy, MD-3, 1000 Independence Avenue SW, Washington, DC 20585.

39. G. B. Stevenson, U.S. Department of Energy, MD-4, 1000 Independence Avenue SW, Washington, DC 20585.

40. J. H. Thompson, U.S. Department of Energy, MD-4, 1000 Independence Avenue SW, Washington, DC 20585.

41. H. R. Trellue, Los Alamos National Laboratory, P.O. Box 1663, MS-K551, Los Alamos, NM 87545

42. T. H. Wynn, U.S. Department of Energy, ORO, P.O. Box 2001, Oak Ridge, TN 37831-8283. 
Table 3-2. Radiation Doses (Whole Body) (CEDE) to Involved Workers During Modification of the Lead Assembly Fabrication Facility

\begin{tabular}{|l|c|}
\hline Average Annual Dose to All Involved Workers at the Facility (mrem) & 383 \\
\hline Maxir.um Dose to an Involved Worker at the Facility (mrem) & 500 \\
\hline Total Number of Involved Workers & 15 \\
\hline
\end{tabular}

\subsection{Wastes Generated During Facility Modifications}

A minor amount of waste is expected to be generated from the facility modifications for the lead assembly fabrication effort. This waste will mainly be generated during the removal of gloveboxes and the replacement of specified equipment in the glovebox line. The waste produced from these modifications would be limited to nonregulated low-level and TRU wastes. No contaminants, such as lead, are expected and hence it will not be considered RCRA, or regulated, waste.

The compatible LLW resulting from the decontamination of a glovebox includes such items as paper, rags, and gloves, and is disposed in cardboard boxes. These boxes are approximately $0.30 \mathrm{~m}(1 \mathrm{ft})$ by $0.30 \mathrm{~m}(1 \mathrm{ft})$ by $0.61 \mathrm{~m}(2 \mathrm{ft})$, or $0.057 \mathrm{~m}^{3}\left(2 \mathrm{ft}^{3}\right)$ in volume and on average weigh $7 \mathrm{~kg}(15 \mathrm{lb})$ when they contain LLW. Ninety of these boxes are packaged at a time to comprise a volume of $5.1 \mathrm{~m}^{3}\left(180 \mathrm{ft}^{3}\right)$ and are placed in a dumpster for shipping to a disposal area such as Area G in TA-54. Other low-level noncompactible waste (such as metal, glass, equipment, etc.) are placed in $2.5 \mathrm{~m}^{3}\left(90 \mathrm{ft}^{3}\right)$ boxes that on average weigh approximately $1,015 \mathrm{~kg}$ $(2,240 \mathrm{lb})$ each. It is estimated that the decontamination of one glove box generates about $2.5 \mathrm{~m}^{3}$ $\left(90 \mathrm{ft}^{3}\right)$ of waste. Thus, it is estimated that $5.0 \mathrm{~m}^{3}\left(180 \mathrm{ft}^{3}\right)$ of $\mathrm{LLW}$ would be generated during the removal of two contaminated gloveboxes.

The TRU waste generated during facility modifications would include the two contaminated gloveboxes to be removed, possibly the sintering furnace residing in the gloveboxes identified for removal, and possibly the two blenders and two mills identified for replacement (it is currently unclear if these pieces of equipment will continue to be used in other gloveboxes or require disposal). The two gloveboxes (which are currently in Room 126) are $2.4 \mathrm{~m}(8 \mathrm{ft}$ ) long and $1.5 \mathrm{~m}$ $(5 \mathrm{ft})$ in width, one being single height and the other being double height. The average weight of a glovebox is $3,800 \mathrm{~kg}(8,300 \mathrm{lb})$, and the average volume is $10 \mathrm{~m}^{3}\left(353 \mathrm{ft}^{3}\right)$. Because the gloveboxes are considered to be oversized TRU waste, special packaging is required; therefore, custom-designed plywood boxes are built for each glovebox for shipment. The gloveboxes will probably also be compacted at the WCRRF Building in TA-50 before they are sent for storage and/or disposal.

The two blenders are approximately $0.61 \mathrm{~m}(2 \mathrm{ft})$ wide, $0.30 \mathrm{~m}(1 \mathrm{ft})$ deep, $0.46 \mathrm{~m}(18 \mathrm{in})$ high, and weigh $14 \mathrm{~kg}$ (30 lb) each. The mills are approximately $0.38 \mathrm{~m}(15 \mathrm{in}), 0.76 \mathrm{~m}$ (30 in) deep, $0.30 \mathrm{~m}(1 \mathrm{ft}) \mathrm{high}$, and weigh $27 \mathrm{~kg}(60 \mathrm{lb})$ each. The sintering furnace is $0.38 \mathrm{~m}(15 \mathrm{in})$ in diameter and is $0.46 \mathrm{~m}$ (18 in) tall. All the aforementioned TRU waste will be wrapped in plastic and placed in 0.208- $\mathrm{m}^{3}$ (55-gal.) waste drums for disposal in TA-54's Area G. On average, these containers weigh $150 \mathrm{~kg}(330 \mathrm{lb})$ each.

The radionuclides that will be present in both the LLW and TRU waste consist mainly of ${ }^{239} \mathrm{Pu}$, ${ }^{235} \mathrm{U}$, and ${ }^{241} \mathrm{Am}$. No other contaminants are expected to be present. Modifications to previously contaminated land are not planned, and no new treatment, storage, or disposal facilities will be created as a result of modifications. Furthermore, no radioactive emissions are anticipated to be released from the facility as a result of the modifications. 
- installation of two new gloveboxes, and

- installation of rod loading and welding equipment in clean gloveboxes.

Based on data obtained from operational experience in $\mathrm{PF}-4$, the number of person-hours required to complete the tasks outlined atrove were estimated by type of craft support and are shown in Table 3-1, along with the number of involved workers by craft.

It was assumed for this estimate that nonglovebox modifications (i.e., installation of storage racks) would not require unusual or sigrificant resources.

\subsection{Employment Needs}

The level of manpower needed to complete the necessary modifications for the lead assembly fabrication effort was detailed in section 3.1. Using this information, the total number of involved workers for this effort is then estimated as 15, as shown in Table 3-2.

Using data gained from operational experience in PF-4, assumptions were made as to the expected dose to workers involved in performing activities similar to those detailed in Table 3-1. These assumptions are that

- 50\% of manpower effort is needed for contaminated work (removal of contaminated gloveboxes and replacement of equipment in glovebox line),

- such contaminated work yields a conservative dose of $2 \mathrm{mrem} / \mathrm{h}$ to any one worker,

- $50 \%$ of manpower effort is needed for clean work (installation and removal of clean gloveboxes, other activities not involving glovebox line),

- such clean work yields a conservative dose of $0.5 \mathrm{mrem} / \mathrm{h}$ to any one worker, and

- Radiological Control Terhnicians (RCTs) receive a dose of only $0.5 \mathrm{mrem} / \mathrm{h}$ for both contaminated and clean work

Using the above assumptions and the manpower requirements for each craft provided in Section 3.1 , the average dose to each type of involved worker can be estimated. The maximum dose to an involved worker, therefore, was estimated to be $500 \mathrm{mrem}$, as shown in Table 3-2. This maximum dose would be received by pipefitters, as they require the highest number of personhours for this effort. The average of the three crafts, and hence the average annual dose to an involved worker, is $383 \mathrm{mrem}$, which is also shown in Table 3-2.

Table 3-1. Manpower Required for Glovebox Line Modifications

\begin{tabular}{|l|c|c|}
\hline Craft Type & $\begin{array}{c}\text { Manpower Required } \\
\text { (person-hours) }\end{array}$ & $\begin{array}{c}\text { Number of Involved } \\
\text { Workers }\end{array}$ \\
\hline Pipefitters & 2000 & 5 \\
\hline Electricians & 1000 & 3 \\
\hline Sheet-Metal Workers & 1500 & 5 \\
\hline Radiological Control Technicians & 250 & 2 \\
\hline
\end{tabular}




\subsection{Modifications}

Most of the activities for the lead assembly fabrication effort at Los Alamos are proposed to occur within PF-4 at TA-55 (see Section 2.0 for more information). The operational fuel fabrication laboratories (Rooms 125 and 126) will be used wi't minor modifications tr fabricate the lead assembly fuel. These modifications are mainly equipment upgrades, and include

- purchasing and installing production model blending and milling equipment in existing gloveboxes, and

- purchasing and installing a more prototypic ceramic sintering furnace in place of existing gloveboxes. Either a pot-type batch or pusher-type continuous design is envisioned.

With the exception of the sintering furnace installation, each of the modifications is performed by opening an existing glovebox (via a window or the top), installing the new piece of equipment, and closing the glovebox (either with the removed window or top or with a new extended top). The sintering furnace installation will first require the removal of one or two existing gloveboxes (including decontamination and decommissioning) and the installation of a new glovebox furnace system. Where appropriate, new utility lines will need to be added.

It is most likely that the majority of the analytical chemistry activities will take place in the already operational laboratories within the CMR Building. However, already planned upgrades to Room 124 (next door to the fuel fabrication laboratories) could provide on-site analytical chemistry capabilities for the lead assembly fabrication effort.

The rod loading and welding activities are also proposed for PF-4, in Room 201. For this effort, minor modifications would be needed. One uncontaminated glovebox would be relocated, and two new special-purpose gloveboxes would be installed for rod loading, welding, examination, and decontamination. The appropriate loading and welding equipment would be installed, along with a certain amount of rod inspection capabilities (such as a helium leak check capability) and possibly rod storage racks.

Although rod non-destructive examination (NDE) and bundle assembly are proposed to take place elsewhere (i.e., RAMROD or CMR), it is assumed that the bundle storage could be done in PF-4, most likely in the basement area. Storage racks would be needed in the designated area. The SST shipments will originate from PF-4, so some sort of bundle storage will be needed there in any case.

\subsection{Construction Resource Needs}

The modifications necessary for implementation of the lead assembly fabrication effort have been described in detail above. All of the modifications needed involve the existing glovebox line and related equipment. No modifications to facilities or structures are expected; therefore, no significant construction resource requirements are expected. The only resource requirement that would see an increase over routine operations would be manpower needed to perform the modifications. The tasks that require the most manpower are modifications to the actual glovebox line, including

- installation of blender and mill,

- decontamination and decommissioning of one or two contaminated gloveboxes,

- installation of sintering furnace,

- relocation of one uncontaminated glovebox, 
Table 2.2.6-1. (cont) Requested Information for Waste Management

\begin{tabular}{|c|c|c|c|c|c|c|}
\hline \multirow[t]{2}{*}{$\begin{array}{c}\text { Waste } \\
\text { Category }\end{array}$} & \multirow{2}{*}{$\begin{array}{c}\text { Current } \\
\text { Annual } \\
\text { Generation } \\
\text { Rate } \\
\end{array}$} & \multirow{2}{*}{$\begin{array}{l}\text { Amount } \\
\text { in } \\
\text { Invent- } \\
\text { ory }\end{array}$} & & Available & \multirow{2}{*}{$\begin{array}{c}\text { TSD } \\
\text { Facilities } \\
\text { Inventory }\end{array}$} & \multirow[b]{2}{*}{ Capacity } \\
\hline & & & $\begin{array}{l}\text { Building } \\
\text { Name }\end{array}$ & TSD Method & & \\
\hline $\begin{array}{l}\text { LLW } \\
\text { Liquid, } 1 \text { (gal.) }\end{array}$ & $\begin{array}{l}20,400,000 \\
(5,400,000)\end{array}$ & 0 & $\begin{array}{l}\text { TA-50 } \\
\text { RLWTF }\end{array}$ & $\begin{array}{c}\text { Treatment/ } \\
\text { Solidification }\end{array}$ & N/A & N/A \\
\hline Solid, $\mathrm{m}^{3}\left(\mathrm{ft}^{3}\right)$ & $\begin{array}{c}2,000- \\
4,000 \\
(70- \\
140,000\end{array}$ & 0 & $\begin{array}{l}\text { TA-54 } \\
\text { Area G }\end{array}$ & $\begin{array}{l}\text { Compaction/ } \\
\text { Disposal }\end{array}$ & $\begin{array}{c}250,000 \\
(8,800,000)\end{array}$ & $\begin{array}{c}252,500 \\
(8,900,000)\end{array}$ \\
\hline $\begin{array}{l}\text { Mixed LLW } \\
\text { Liquid, I (gal.) } \\
\text { Solid, } \mathrm{m}^{3}\left(\mathrm{ft}^{3}\right)\end{array}$ & $\begin{array}{l}\text { N/A } \\
\text { N/A }\end{array}$ & $\begin{array}{l}\text { N/A } \\
\text { N/A }\end{array}$ & $\begin{array}{l}\text { N/A } \\
\text { N/A }\end{array}$ & $\begin{array}{l}\text { N/A } \\
\text { N/A }\end{array}$ & $\begin{array}{l}\text { N/A } \\
\text { N/A }\end{array}$ & $\begin{array}{l}\text { N/A } \\
\text { N/A }\end{array}$ \\
\hline $\begin{array}{l}\text { Hazardous } \\
\text { Liquid, } 1 \text { (gal.) } \\
\text { Solid, } \mathrm{m}^{3}\left(\mathrm{ft}^{3}\right)\end{array}$ & $\begin{array}{l}\text { N/A } \\
\text { N/A }\end{array}$ & $\begin{array}{l}\text { N/A } \\
\text { N/A }\end{array}$ & $\begin{array}{l}\text { N/A } \\
\text { N/A }\end{array}$ & $\begin{array}{l}\text { N/A } \\
\text { N/A }\end{array}$ & $\begin{array}{l}\text { N/A } \\
\text { N/A }\end{array}$ & $\begin{array}{l}\text { N/A } \\
\text { N/A }\end{array}$ \\
\hline $\begin{array}{l}\text { Nonhazardous } \\
\text { (Sanitary) } \\
\text { Liquid, 1 (gal.) } \\
\text { Solid, } \mathrm{m}^{3}\left(\mathrm{ft}^{3}\right)\end{array}$ & $\begin{array}{l}\text { N/A } \\
\text { N/A }\end{array}$ & $\begin{array}{l}\text { N/A } \\
\text { N/A }\end{array}$ & $\begin{array}{l}\text { N/A } \\
\text { N/A }\end{array}$ & $\begin{array}{l}\text { N/A } \\
\text { N/A }\end{array}$ & $\begin{array}{l}\text { N/A } \\
\text { N/A }\end{array}$ & $\begin{array}{l}\text { N/A } \\
\text { N/A }\end{array}$ \\
\hline $\begin{array}{l}\text { Nonhazardous } \\
\text { (Other) } \\
\text { Liquid, } 1 \text { (gal.) } \\
\text { Solid, } \mathrm{m}^{3}\left(\mathrm{ft}^{3}\right) \\
\end{array}$ & $\begin{array}{l}\mathrm{N} /: \mathrm{i} \\
\mathrm{N} / \mathrm{A}\end{array}$ & $\begin{array}{l}\text { N/A } \\
\text { N/A }\end{array}$ & $\begin{array}{l}\text { N/A } \\
\text { N/A }\end{array}$ & $\begin{array}{l}\text { N/A } \\
\text { N/A }\end{array}$ & $\begin{array}{l}\text { N/A } \\
\text { N/A }\end{array}$ & $\begin{array}{l}\text { N/A } \\
\text { N/A }\end{array}$ \\
\hline
\end{tabular}


Table 2.2.6-1. (cont) Requested Information for Waste Management

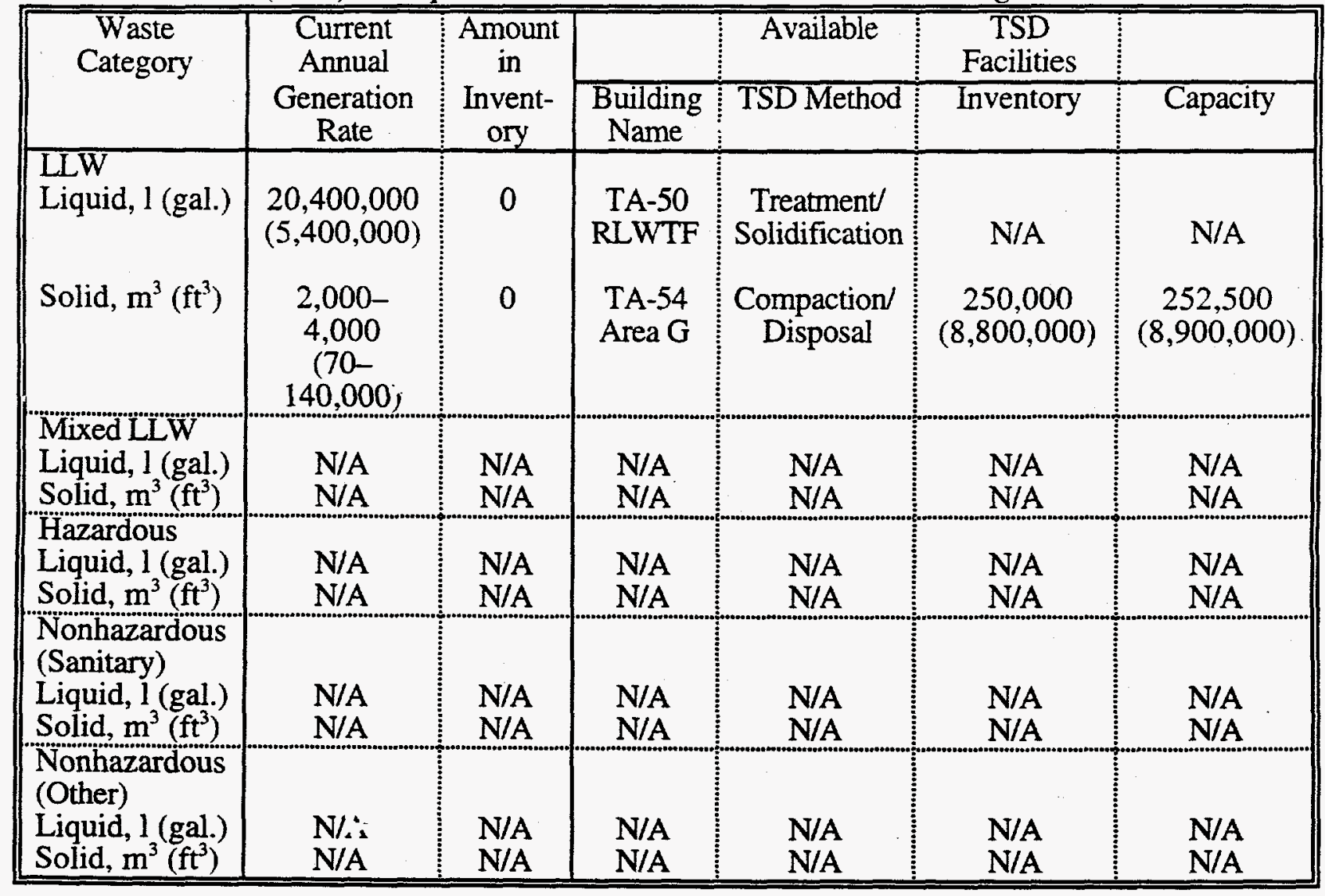




\subsection{Modifications}

Most of the activities for the lead assembly fabrication effort at Los Alamos are proposed to occur within PF-4 at TA-55 (see Section 2.0 for more information). The operational fuel fabrication laboratories (Rooms 125 and 126) will be used with minor modifications tr fabricate the lead assembly fuel. These modifications are mainly equipment upgrades, and include

- purchasing and installing production model blending and milling equipment in existing gloveboxes, and

- purchasing and installing a more prototypic ceramic sintering furnace in place of existing gloveboxes. Either a pot-type batch or pusher-type continuous design is envisioned.

With the exception of the sintering furnace installation, each of the modifications is performed by opening an existing glovebox (via a window or the top), installing the new piece of equipment, and closing the glovebox (either with the removed window or top or with a new extended top). The sintering furnace installation will first require the removal of one or two existing gloveboxes (including decontamination and decommissioning) and the installation of a new glovebox furnace system. Where appropriate, new utility lines will need to be added.

It is most likely that the majority of the analytical chemistry activities will take place in the already operational laboratories within the CMR Building. However, already planned upgrades to Room 124 (next door to the fuel fabrication laboratories) could provide on-site analytical chemistry capabilities for the lead assembly fabrication effort.

The rod loading and welding activities are also proposed for PF-4, in Room 201. For this effort, minor modifications would be needed. One uncontaminated glovebox would be relocated, and two new special-purpose gloveboxes would be installed for rod loading, welding, examination, and decontamination. The appropriate loading and welding equipment would be installed, along with a certain amount of rod inspection capabilities (such as a helium leak check capability) and possibly rod storage racks.

Although rod non-destructive examination (NDE) and bundle assembly are proposed to take place elsewhere (i.e., RAMROD or CMR), it is assumed that the bundle storage could be done in PF-4, most likely in the basement area. Storage racks would be needed in the designated area. The SST shipments will originate from PF-4, so some sort of bundle storage will be needed there in any case.

\subsection{Construction Resource Needs}

The modifications necessary for inplementation of the lead assembly fabrication effort have been described in detail above. All of the modifications needed involve the existing glovebox line and related equipment. No modifications to facilities or structures are expected; therefore, no significant construction resource requirements are expected. The only resource requirement that would see an increase over routine operations would be manpower needed to perform the modifications. The tasks that require the most manpower are modifications to the actual glovebox line, including

- installation of blender and mill,

- decontamination and decommissioning of one or two contaminated gloveboxes,

- installation of sintering furnace,

- relocation of one uncontaninated glovebox, 
- installation of two new gloveboxes, and

- installation of rod loading and welding equipment in clean gloveboxes.

Based on data obtained from operational experience in $\mathrm{PF}-4$, the number of person-hours required to complete the tasks outlined above were estimated by type of craft support and are shown in Table 3-1, along with the number of involved workers by craft.

It was assumed for this estimate that nonglovebox modifications (i.e., installation of storage racks) would not require unusual or significant resources.

\subsection{Employment Needs}

The level of manpower needed to complete the necessary modifications for the lead assembly fabrication effort was detailed in Section 3.1. Using this information, the total number of involved workers for this effort is then estimated as 15, as shown in Table 3-2.

Using data gained from operational experience in PF-4, assumptions were made as to the expected dose to workers involved in performing activities similar to those detailed in Table 3-1. These assumptions are that

- $50 \%$ of manpower effort is needed for contaminated work (removal of contaminated gloveboxes and replacement of equipment in glovebox line),

- such contaminated work yields a conservative dose of $2 \mathrm{mrem} / \mathrm{h}$ to any one worker,

- $50 \%$ of manpower effort is needed for clean work (installation and removal of clean gloveboxes, other activities not involving glovebox line),

- such clean work yields a conservative dose of $0.5 \mathrm{mrem} / \mathrm{h}$ to any one worker, and

- Radiological Control Technicians (RCTs) receive a dose of only $0.5 \mathrm{mrem} / \mathrm{h}$ for both contaminated and clean work

Using the above assumptions and the manpower requirements for each craft provided in Section 3.1 , the average dose to each type of involved worker can be estimated. The maximum dose to an involved worker, therefore, was estimated to be $500 \mathrm{mrem}$, as shown in Table 3-2. This maximum dose would be received by pipefitters, as they require the highest number of personhours for this effort. The average of the three crafts, and hence the average annual dose to an involved worker, is 383 mrem, which is also shown in Table 3-2.

Table 3-1. Manpower Required for Glovebox Line Modifications

\begin{tabular}{|l|c|c|}
\hline Craft Type & $\begin{array}{c}\text { Manpower Required } \\
\text { (person-hours) }\end{array}$ & $\begin{array}{c}\text { Number of Involved } \\
\text { Workers }\end{array}$ \\
\hline Pipefitters & 2000 & 5 \\
\hline Electricians & 1000 & 3 \\
\hline Sheet-Metal Workers & 1500 & 5 \\
\hline Radiological Control Technicians & 250 & 2 \\
\hline
\end{tabular}


Table 3-2. Radiation Doses (Whole Body) (CEDE) to Involved Workers During Modification of the Lead Assembly Fabrication Facility

\begin{tabular}{|l|c|}
\hline Average Annual Dose to All Involved Workers at the Facility (mrem) & 383 \\
\hline Maxir.uum Dose to an Involved Worker at the Facility (mrem) & 500 \\
\hline Total Number of Involved Workers & 15 \\
\hline
\end{tabular}

\subsection{Wastes Generated During Facility Modifications}

A minor amount of waste is expected to be generated from the facility modifications for the lead assembly fabrication effort. This waste will mainly be generated during the removal of gloveboxes and the replacement of specified equipment in the glovebox line. The waste produced from these modifications would be limited to nonregulated low-level and TRU wastes. No contaminants, such as lead, are expected and hence it will not be considered RCRA, or regulated, waste.

The compatible LLW resulting from the decontamination of a glovebox includes such items as paper, rags, and gloves, and is disposed in cardboard boxes. These boxes are approximately $0.30 \mathrm{~m}(1 \mathrm{ft})$ by $0.30 \mathrm{~m}(1 \mathrm{ft})$ by $0.61 \mathrm{~m}(2 \mathrm{ft})$, or $0.057 \mathrm{~m}^{3}\left(2 \mathrm{ft}^{3}\right)$ in volume and on average weigh $7 \mathrm{~kg}(15 \mathrm{lb})$ when they contain LLW. Ninety of these boxes are packaged at a time to comprise a volume of $5.1 \mathrm{~m}^{3}\left(180 \mathrm{ft}^{3}\right)$ and are placed in a dumpster for shipping to a disposal area such as Area $G$ in TA-54. ()ther low-level noncompactible waste (such as metal, glass, equipment, etc.) are placed in $2.5 \mathrm{~m}^{3}\left(90 \mathrm{ft}^{3}\right.$ ) boxes that on average weigh approximately $1,015 \mathrm{~kg}$ $(2,240 \mathrm{lb})$ each. It is estimated that the decontamination of one glove box generates about $2.5 \mathrm{~m}^{3}$ $\left(90 \mathrm{ft}^{3}\right)$ of waste. Thus, it is estimated that $5.0 \mathrm{~m}^{3}\left(180 \mathrm{ft}^{3}\right)$ of LLW would be generated during the removal of two contaminated gloveboxes.

The TRU waste generated during facility modifications would include the two contaminated gloveboxes to be removed, possibly the sintering furnace residing in the gloveboxes identified for removal, and possibly the two blenders and two mills identified for replacement (it is currently unclear if these pieces of equipmient will continue to be used in other gloveboxes or require disposal). The two gloveboxes (which are currently in Room 126) are $2.4 \mathrm{~m}(8 \mathrm{ft}$ ) long and $1.5 \mathrm{~m}$ $(5 \mathrm{ft})$ in width, one being single height and the other being double height. The average weight of a glovebox is $3,800 \mathrm{~kg}(8,300 \mathrm{lb})$, and the average volume is $10 \mathrm{~m}^{3}\left(353 \mathrm{ft}^{3}\right)$. Because the gloveboxes are considered to be oversized TRU waste, special packaging is required; therefore, custom-designed plywood boxes are built for each glovebox for shipment. The gloveboxes will probably also be compacted at the WCRRF Building in TA-50 before they are sent for storage and/or disposal.

The two blenders are approximately $0.61 \mathrm{~m}(2 \mathrm{ft})$ wide, $0.30 \mathrm{~m}(1 \mathrm{ft})$ deep, $0.46 \mathrm{~m}(18 \mathrm{in})$ high,

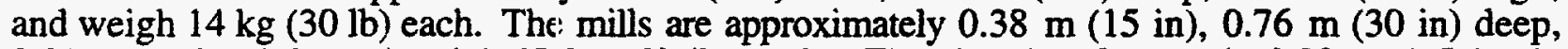
$0.30 \mathrm{~m}$ (1 ft) high, and weigh $27 \mathrm{~kg}(60 \mathrm{lb})$ each. The sintering furnace is $0.38 \mathrm{~m}(15 \mathrm{in})$ in diameter and is $0.46 \mathrm{~m}$ (18 in) tall. All the aforementioned TRU waste will be wrapped in plastic and placed in 0.208- $\mathrm{m}^{3}$ (55-gal.) waste drums for disposal in TA-54's Area G. On average, these containers weigh $150 \mathrm{~kg}(330 \mathrm{lb})$ each.

The radionuclides that will be present in both the LLW and TRU waste consist mainly of ${ }^{239} \mathrm{Pu}$, ${ }^{235} \mathrm{U}$, and ${ }^{241} \mathrm{Am}$. No other contarinants are expected to be present. Modifications to previously contaminated land are not planned, and no new treatment, storage, or disposal facilities will be created as a result of modification:s. Furthermore, no radioactive emissions are anticipated to be released from the facility as a result of the modifications. 


\section{INTERNAL DISTRIBUTION}
1. J. J. Carbajo
2. B. S. Cowell
3. S. E. Fisher
4. E. C. Fox
5. R. G. Gilliland
6. S. R. Greene
7. S. A. Hodge
8. R. Holdaway
9. S. B. Ludwig
10. G. T. Mays
11. K. L. McElhaney
12. G. E. Michaels
13. R. N. Morris

\author{
14. D. L. Moses \\ 15. D. G. O'Connor \\ 16. R. T. Primm III \\ 17. R. R. Rahn \\ 18. J. D. Sease \\ 19. C. C. Southmayd \\ 20. V.S. White \\ 21. C. K. Williams \\ 22. D. L. Williams, Jr. \\ 23. Central Research Library \\ 24-25. ORNL Laboratory Records (OSTI) \\ 26. ORNL Laboratory Records-RC
}

\section{EXTERNAL DISTRIBUTION}

27. M. J. Barr, Los Alamos National Laboratory, P.O. Box 1663, MS-E583, Los Alamos, NM 87545

28. J. J. Buksa, Los Alamos National Laboratory, P.O. Box 1663, MS-K551, Los Alamos, NM 87545

29. H. R. Canter, U.S. Department of Energy, MD-3, 1000 Independence Avenue SW, Washington, DC 20585.

30. S. L. Eaton, Los Alamos National Laboratory, P.O. Box 1663, MS-K551, Los Alamos, NM 87545

31. J. Eichner, Science Applications International Corp., 20201 Century Blvd., Germantown, MD 20874.

32. K. Gandee, U.S. Department of Energy, MD-4, 1000 Independence Avenue SW, Washington, DC 20585.

33. C. Groome, Science Applications International Corp., 20201 Century Blvd., Germantown, MD 20874.

34. D. Hirrlinger, Science Applications International Corp., 20201 Century Blvd., Germantown, MD 20874.

35. J. V. Johnson, U.S. Department of Energy, MD-4, 1000 Independence Avenue SW, Washington, DC 20585.

36. D. J. Nulton, U.S. Department of Energy, MD-4, 1000 Independence Avenue SW, Forrestal Bldg., Room 6G-050, Washington, DC 20585.

37. D. Peko, U.S. Department of Energy, MD-3, 1000 Independence Avenue SW, Washington, DC 20585.

38. P. T. Rhoads, U.S. Department of Energy, MD-3, 1000 Independence Avenue SW, Washington, DC 20585.

39. G. B. Stevenson, U.S. Department of Energy, MD-4, 1000 Independence Avenue SW, Washington, DC 20585.

40. J. H. Thompson, U.S. Department of Energy, MD-4, 1000 Independence Avenue SW, Washington, DC 20585.

41. H. R. Trellue, Los Alamos National Laboratory, P.O. Box 1663, MS-K551, Los Alamos, NM 87545

42. T. H. Wynn, U.S. Department of Energy, ORO, P.O. Box 2001, Oak Ridge, TN 37831-8283. 


\section{DOE PLBLIC READING ROOMS}

43. Albuquerque Operations Office, TV। Community College Library, Montoya Campus, 4700 Morris, NE, Albuquerque, NM 87111.

44. Amarillo Area Office, U.S. Department of Energy, Amarillo College, Lynn Library/Learning Center, 2201 South Washington, P.O. Box 447, Amarillo, TX 79178.

45. U.S. DOE Reading Room, Carson County Library, 401 Main Street, P.O. Box 339, Panhandle, TX 79068.

46. Chicago Operations Office, Office of the Manager/Communications, U.S. Department of Energy, 9800 South Cass Avenue, Argonne, Il 60439.

47. Idaho National Engineering and Environmental Laboratory, Idaho Public Reading Room, 1776 Science Center Drive, Idaho Falls, ID 83402.

48. Los Alamos National Laboratory, U.S. Department of Energy, c/o Los Alamos Community Reading Room, 1350 Central, Suite 101, Los A.lamos, NM 87544.

49. Nevada Operations Office, U.S. Department of Energy, Public Reading Room, 2621 Losse Road, North Las Vegas, NV 89030.

50. Oak Ridge Operations Office, U.S. Llepartment of Energy, Public Reading Room, 200 Administration Road, Room G-217, Oak Ridge, TN 37831-8501.

51. Richland Operations Office, DOE Public Reading Room, 100 Sprout Road, Room 130 West, P.O. Box 999, M/S H2-53, Richland, WA 9935?.

52. Rocky Flats Office, Front Range Conmunity College Library, 3645 West 112th Avenue, Westminster, CO 80030.

53. Sandia National Laboratory/CA, Livermore Public Library, 1000 S. Livermore Avenue, Livermore, CA 94550.

54. Savannah River Operations Office, Gregg-Graniteville Library, University of South Carolina-Aiken, 171 University Parkway, Aiken, SC 29801.

55. U.S. Department of Energy, Freedom of Information/Privacy Act Public Reading Room, Forrestal Building, Room 1E-190, 1000 Independence Avenue SW, Washington, DC 20585. 